\title{
Alaska Resource Data File, Wiseman quadrangle, Alaska
}

By Joe M. Britton ${ }^{1}$

Open-File Report 03-447

2003

This report is preliminary and has not been reviewed for conformity with U.S. Geological Survey editorial standards or with the North American Stratigraphic Code. Any use of trade, firm, or product names is for descriptive purposes only and does not imply endorsement by the U.S. Government.

U.S. DEPARTMENT OF THE INTERIOR

U.S. GEOLOGICAL SURVEY

${ }^{1}$ Anchorage, Alaska 


\section{Wiseman quadrangle}

Descriptions of the mineral occurrences shown on the accompanying figure follow. See U.S. Geological Survey (1996) for a description of the information content of each field in the records. The data presented here are maintained as part of a statewide database on mines, prospects and mineral occurrences throughout Alaska.

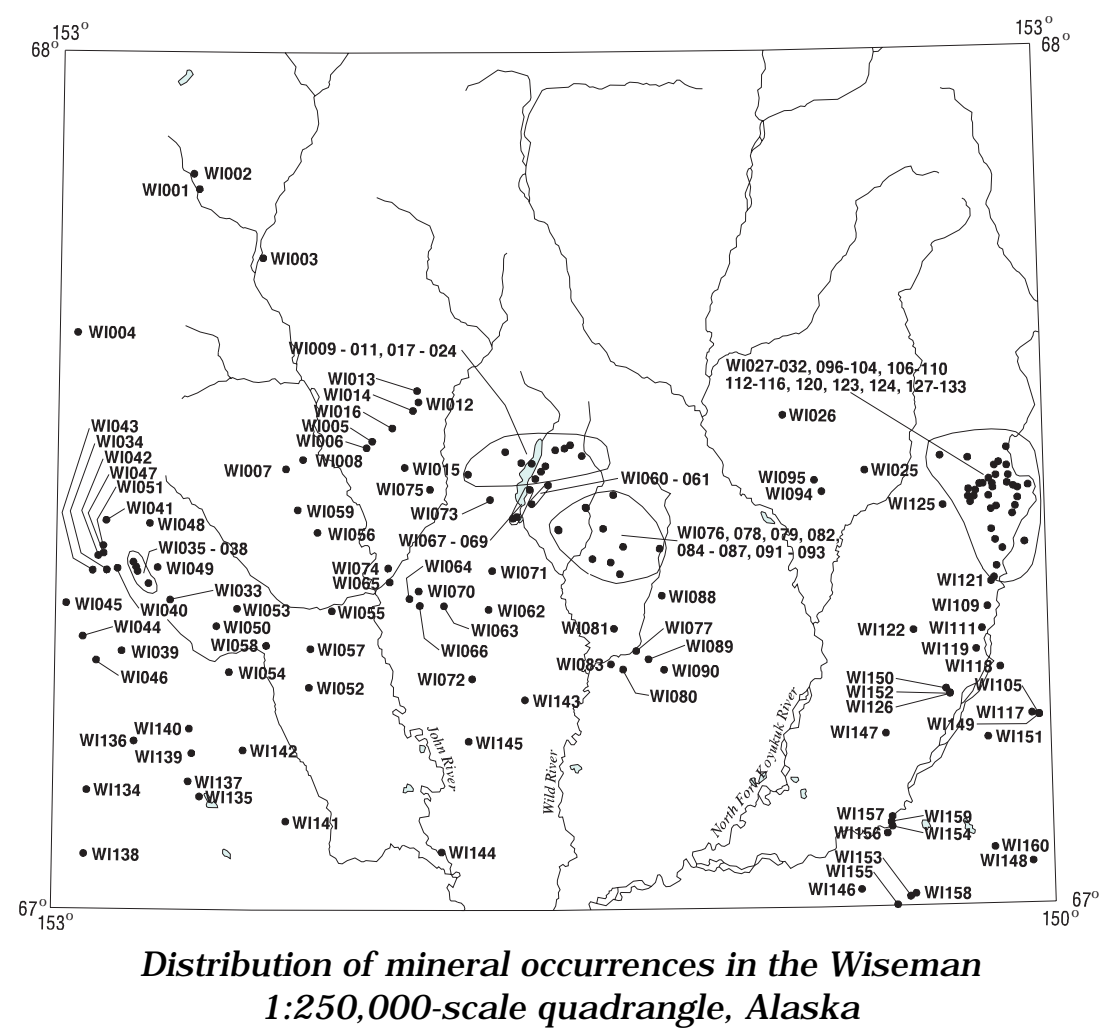

This and related reports are accessible through the USGS World Wide Web site http://ardf.wr.usgs.gov. Comments or information regarding corrections or missing data, or requests for digital retrievals should be directed to: Frederic Wilson, USGS, 4200 University Dr., Anchorage, AK 99508-4667, e-mail fwilson@usgs.gov, telephone (907) 786-7448. This compilation is authored by:

Joe M. Britton

Anchorage, AK

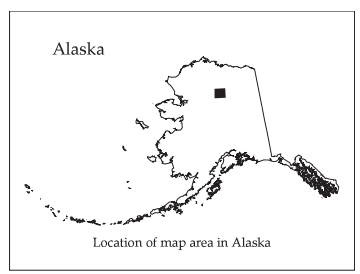

This report is preliminary and has not been reviewed for conformity with U.S. Geological Survey editorial standards or with the North American Stratigraphic code. Any use of trade, product, or firm names is for descriptive purposes only and does not imply endorsement by the U.S. Government. 


\section{Site name(s): Unnamed (near Walkaround Creek)}

Site type: Occurrence

ARDF no.: WI001

Latitude: 67.8401

Quadrangle: WI D-6

Longitude: 152.5775

Location description and accuracy:

Following Brosge and Reiser (1960), this occurrence is on the east side of Hunt Fork at an elevation of about 420 meters; it is about 0.4 mile south-southeast of the center of section 20, T. 35 N., R. 22 W., of the Fairbanks Meridian. The location is accurate within 1 mile. Early reports ( Berg and Cobb, 1967; Cobb, 1972 [OF 76-340]; Grybeck, 1977 ) commonly refer to both this site and WI002 as 'Hunt Fork'.

\section{Commodities:}

Main: $\mathrm{Pb}$

Other:

Ore minerals: Galena

Gangue minerals: Quartz

Geologic description:

This occurrence consists of a galena-bearing, quartz vein (Brosge and Reiser, 1960). The rocks in the vicinity are black slate and phyllite of the Upper Devonian, Hunt Fork Shale.

\section{Alteration:}

Age of mineralization:

Deposit model:

Deposit model number (After Cox and Singer, 1986 or Bliss, 1992):

Production Status: None

Site Status: Inactive

Workings/exploration:

Production notes:

Reserves:

Additional comments:

The site is in Gates of the Arctic National Park.

\section{References:}

Brosge and Reiser, 1960; Berg and Cobb, 1967; Cobb, 1972 (MF-469); Cobb, 1976 (OF76-340); Grybeck, 1977; Bliss and others, 1988. 
Primary reference: Brosge and Reiser, 1960

Reporter(s): J.M. Britton (Anchorage)

Last report date: $8 / 9 / 2002$ 


\section{Site name(s): Unnamed (on lower Walkaround Creek)}

Site type: Occurrence

ARDF no.: WI002

Latitude: 67.8580

Quadrangle: WI D-6

Longitude: 152.5947

Location description and accuracy:

Following Brosge and Reiser (1960), this occurrence is on Walkaround Creek at an elevation of about 430 meters; it is in the SW1/4 section 17, T. 35 N., R. 22 W., of the Fairbanks Meridian. The location is accurate within 1 mile. Early reports by Berg and Cobb (1967), Cobb (1972 [OF 76-340]), and Grybeck (1977) commonly refer to both this site and WI001 as 'Hunt Fork'.

\section{Commodities:}

Main: $\mathrm{Pb}$

Other:

Ore minerals: Galena

Gangue minerals: Quartz

Geologic description:

This occurrence consists of a galena-bearing quartz vein (Brosge and Reiser, 1960). The country rocks are black slate and phyllite of the Upper Devonian Hunt Fork Shale.

\section{Alteration:}

Age of mineralization:

Deposit model:

Deposit model number (After Cox and Singer, 1986 or Bliss, 1992):

Production Status: None

Site Status: Inactive

Workings/exploration:

Production notes:

Reserves:

Additional comments:

The site is in Gates of the Arctic National Park.

\section{References:}

Brosge and Reiser, 1960; Berg and Cobb, 1967; Cobb, 1972 (MF-469); Cobb, 1976 (OF76-340); Grybeck, 1977; Bliss and others, 1988. 
Primary reference: Brosge and Reiser, 1960

Reporter(s): J.M. Britton (Anchorage)

Last report date: $8 / 9 / 2002$ 


\section{Site name(s): John River}

Site type: Occurrence

ARDF no.: WI003

Latitude: 67.7602

Quadrangle: WI D-5

Longitude: 152.3798

Location description and accuracy:

The original reference for this occurrence only describes the location as being on John River near Hunt Fork (Joesting, 1942). Based on subsequent descriptions (Berg and Cobb, 1967; Cobb, 1972 [MF 469]; Maas, 1987), it is probably at an elevation of about 1,500 feet on the east side of John River, about 1.5 miles downstream from the mouth of Hunt Fork. These later locations may or may not be more accurate. The location is accurate within 1 mile.

\section{Commodities:}

Main: Sb

Other:

Ore minerals: Stibnite

\section{Gangue minerals:}

\section{Geologic description:}

This occurrence is a stibnite lode, a sample of which assayed 42\% antimony (Joesting, 1942). It is near a fault contact between Upper Devonian, Hunt Fork Shale and Middle or Upper Devonian(?) or older(?), black slate, phyllite. and limestone (Dillon and others, 1986). No other information about this occurrence is available.

\section{Alteration:}

Age of mineralization:

Deposit model:

Simple Sb deposit (?) (Cox and Singer, 1986; model 27d)

Deposit model number (After Cox and Singer, 1986 or Bliss, 1992): $27 d(?)$

Production Status: None

Site Status: Inactive

Workings/exploration:

Only surface sampling.

Production notes:

Reserves:

Additional comments: 


\section{References:}

Schrader, 1904; Brooks, 1905; Smith and Mertie, 1930; Joesting, 1942; Heiner and Wolff, 1968; Berg and Cobb, 1967; Cobb, 1972 (MF-469); Cobb, 1976 (OF76-340); Grybeck, 1977; Cobb, 1981 (OF81-732); Dillon and others, 1986; Maas, 1987.

Primary reference: Joesting, 1942

Reporter(s): J.M. Britton (Anchorage)

Last report date: $8 / 9 / 2002$ 


\section{Site name(s): Unnamed (southwest of Sillyasheen Mountain)}

Site type: Occurrence

ARDF no.: WI004

Latitude: 67.6718

Quadrangle: WI C-6

Longitude: 152.9460

Location description and accuracy:

This occurrence is at an elevation of about 1,520 meters, 0.5 mile west-northwest of the center of section 23, T. 33. N., R. 24 W., of the Fairbanks Meridian. The location is accurate within 1 mile.

\section{Commodities:}

Main: $\mathrm{Cu}$

Other:

Ore minerals: Malachite, unspecified copper sulfides

Gangue minerals:

\section{Geologic description:}

This occurrence consists of unspecified copper sulfides and malachite staining in Devonian phyllite (Brosge and Reiser, 1960). The rocks in the area are a unit of Middle to Upper Devonian(?) calcareous, chloritic wacke, which also includes sandstone, conglomerate, limestone, and phyllite (Dillon and others, 1986). No other information is available.

\section{Alteration:}

Oxidation of copper minerals(s).

Age of mineralization:

Deposit model:

Deposit model number (After Cox and Singer, 1986 or Bliss, 1992):

Production Status: None

Site Status: Inactive

Workings/exploration:

Only surface sampling.

Production notes:

Reserves:

Additional comments:

\section{References:}

Brosge and Reiser, 1960; Cobb, 1972 (MF-469); Cobb, 1976 (OF76-340); Cobb, 1981 (OF81-732); Bliss and others, 1988 . 
Primary reference: Brosge and Reiser, 1960

Reporter(s): J.M. Britton (Anchorage)

Last report date: $8 / 9 / 2002$

\section{Page 9}




\section{Site name(s): Unnamed (east of VABM Allen)}

Site type: Occurrence

ARDF no.: WI005

Latitude: 67.5469

Quadrangle: WI C-5

Longitude: 152.0431

Location description and accuracy:

This occurrence is located in a high saddle about 0.8 mile east-northeast of VABM Allen and about 4 miles northeast of the junction of Sheep Creek and John River. The occurrence is at an elevation of about 4,000 feet at the southeast corner of section 32, T. 32 N., R. 20 W., of the Fairbanks Meridian. The site is situated between, loc. 6 of Cobb (1972 [MF469]) and sample 284 of Dillon and others (1981 [AOF 133B]. The location is accurate.

\section{Commodities:}

Main: $\mathrm{Cu}$

Other: Mo

Ore minerals: Azurite, bornite, chalcocite, chalcopyrite, covellite, malachite

Gangue minerals: Quartz

Geologic description:

Brosge and Reiser (1960) described copper sulfides and malachite at a fault contact between Devonian Skajit Limestone and a Devonian phyllite and siltstone unit at this location. Dillon and others (1981, sample 284 [AOF 133B]) described disseminated covellite and bornite and malachite stain in pale-green calcschist and quartz veins. This sample contains up to 5,000 ppm copper and 10 ppm molybdenum. Kurtak and others (1999, no. 38) analyzed one rock sample of chlorite-quartz schist that contained chalcocite, malachite and azurite. It has 1,664 ppm copper, 4.8 ppm silver, and 23 ppb gold. Degenhart and others (1978) reported minor amounts of chalcopyrite, bornite and malachite in metamorphosed, reef limestone near VABM Allen, only a short distance west of this location.

\section{Alteration:}

Local oxidation of copper minerals.

Age of mineralization:

Deposit model:

Polymetallic replacement deposit (?) (Cox and Singer, 1986; model 19a)

Deposit model number (After Cox and Singer, 1986 or Bliss, 1992): $19 \mathrm{a}(?)$

Production Status: None

Site Status: Inactive

Workings/exploration:

Surface sampling and reconnaissance geochemical sampling and prospecting in the vicinity by at least four companies prior to 1978 (Degenhart and other, 1978). 


\section{Production notes:}

Reserves:

Additional comments:

See also WI016 and WI006.

\section{References:}

Brosge and Reiser, 1960; Degenhart and others, 1978; Dillon and others, 1981 (AOF 133B); Cobb, 1972 (MF-469); Cobb, 1976 (OF76-340); Grybeck, 1977; Cobb, 1981 (OF81-732); Bliss and others, 1988; Kurtak and others, 1999.

Primary reference: Dillon and others, 1981 (AOF 133B)

Reporter(s): J.M. Britton (Anchorage)

Last report date: $8 / 9 / 2002$ 


\section{Site name(s): Unnamed (south of VABM Allen)}

Site type: Occurrence

ARDF no.: WI006

Latitude: 67.5392

Quadrangle: WI C-5

Longitude: 152.0604

Location description and accuracy:

This occurrence is at an elevation of about 3,500 feet, about 0.4 mile south-southeast of VABM Allen. The occurrence is the site of sample 84 in Dillon and others (1981 [AOF 133B]). The location is accurate within one-half mile.

\section{Commodities:}

Main: $\mathrm{Ag}, \mathrm{Cu}$

Other:

Ore minerals: Bornite, chalcopyrite, covellite, malachite

Gangue minerals: Quartz

\section{Geologic description:}

This occurrence consists of a quartz vein that contains abundant bornite, lesser amounts of covellite, and traces of chalcopyrite altering to malachite. The vein cuts calcareous schist. A sample of the vein contains more than 2\% copper and 100 ppm silver (Dillon and others, 1981, sample 84 [AOF 133B]). Degenhart and others (1978) reported minor amounts of chalcopyrite, bornite, and malachite in metamorphosed, reef limestone a short distance north of this occurrence.

\section{Alteration:}

Chalcopyrite oxidizing to malachite.

Age of mineralization:

Deposit model:

Deposit model number (After Cox and Singer, 1986 or Bliss, 1992):

Production Status: None

Site Status: Inactive

Workings/exploration:

Only surface sampling.

Production notes:

Reserves:

Additional comments:

See also WI005. 


\section{References:}

Degenhart and others, 1978; Dillon and others, 1981 (AOF 133B); Bliss and others, 1988.

Primary reference: Dillon and others, 1981(AOF 133B)

Reporter(s): J.M. Britton (Anchorage)

Last report date: $8 / 9 / 2002$ 


\section{Site name(s): Unnamed (near VABM Pink)}

Site type: Occurrence

ARDF no.: WI007

Latitude: 67.5142

Quadrangle: WI C-5

Longitude: 152.3057

Location description and accuracy:

This occurrence is at an elevation of about 3,700 feet, about 0.5 mile northwest of VABM Pink, in the NE1/4 section 18, T. 31 N., R. 21 W., of the Fairbanks Meridian. The occurrence is the site of sample 518 in Dillon and others (1981 [AOF 133B]). The location is accurate.

\section{Commodities:}

Main: $\mathrm{Ag}, \mathrm{Cu}$

Other:

Ore minerals: Azurite, chalcocite, malachite

Gangue minerals:

\section{Geologic description:}

This occurrence consists of a vein, more than 2 centimeters thick, of azurite, malachite, and chalcocite, in a unit of metamorphosed, conglomerate, sandstone and shale. These rocks underlie marble. A sample of the vein from a dolomite rubble-crop contains $66.4 \%$ copper and 21.7 ppm silver. (Dillon and others, 1981, sample 518 [AOF 133B]).

\section{Alteration:}

Oxidation of copper mineral(s).

Age of mineralization:

Deposit model:

Deposit model number (After Cox and Singer, 1986 or Bliss, 1992):

Production Status: None

Site Status: Inactive

Workings/exploration:

Only surface sampling.

Production notes:

Reserves:

Additional comments:

References:

Dillon and others, 1981 (AOF 133B); Bliss and others, 1988. 
Primary reference: Dillon and others, 1981(AOF 133B)

Reporter(s): J.M. Britton (Anchorage)

Last report date: $8 / 9 / 2002$ 


\section{Site name(s): Unnamed (south of Eagle Creek)}

Site type: Occurrence

ARDF no.: WI008

Latitude: 67.5252

Quadrangle: WI C-5

Longitude: 152.2537

Location description and accuracy:

This occurrence is at an elevation of about 3,100 feet, 0.3 mile south-southeast of the top of hill 3452, near the center of section 9, T. 31 N., R. 21 W., of the Fairbanks Meridian. The location is accurate.

Commodities:

Main: $\mathrm{Cu}$

Other:

Ore minerals: Malachite, unspecified copper sulfides

Gangue minerals:

Geologic description:

This occurrence consists of unspecified copper sulfides and malachite in Devonian, Skajit Limestone (Brosge and Reiser, 1960). The Skajit Limestone is locally broken by thrusts and steep faults. The rocks in the vicinity are Skajit Limestone and Middle Devonian, siliceous clastic rocks (Dillon and others, 1986). No other information is available.

Alteration:

Oxidation of copper mineral(s).

Age of mineralization:

Deposit model:

Deposit model number (After Cox and Singer, 1986 or Bliss, 1992):

Production Status: None

Site Status: Inactive

Workings/exploration:

Only surface sampling.

Production notes:

Reserves:

Additional comments:

References:

Brosge and Reiser, 1960; Cobb, 1972 (MF-469); Cobb, 1976 (OF76-340); Dillon and others, 1986; Bliss and others, 1988; Cobb, 1981 (OF81-732). 
Primary reference: Brosge and Reiser, 1960

Reporter(s): J.M. Britton (Anchorage)

Last report date: $8 / 9 / 2002$ 


\section{Site name(s): Surprise Creek; Summit Creek}

Site type: Mine

ARDF no.: WI009

Latitude: 67.5178

Quadrangle: WI C-4

Longitude: 151.5154

Location description and accuracy:

Surprise Creek (named Summit Creek in reports from the 1930's) flows into the east side of Wild Lake about 0.2 mile north of the mouth of Spring Creek. There is evidence of placer mining activity along a 2mile stretch of the creek, but the mine workings appear to be concentrated along a 500-foot segment about 0.5 mile above the mouth. This mining is in the NW1/4 section 14, T. 31 N., R 18 W., of the Fairbanks Meridian. The location is accurate.

\section{Commodities:}

Main: $\mathrm{Au}$

Other:

Ore minerals: Gold

\section{Gangue minerals:}

\section{Geologic description:}

Placer gold was discovered in 1904 in the modern stream bed of Surprise (Summit) Creek and mining began that year (Reed, 1938). Surprise Creek was sporadically mined from 1904 through about 1937. Mining has been sporadic and in many cases the workings failed to reach bedrock. Where it was reached, the depth to bedrock is 12 to 14 feet but the bedrock surface apparently dips to the north under talus and its depth becomes progressively greater. The gravel in the creek is not frozen. It is very coarse and angular, and contains many large boulders at the top of the section. The gold is coarse, many nuggets occur with the fine gold. The gold occurs in the lower 3 feet of the gravel and on top of the bedrock; its fineness is about 920 . Smith (1932) reported that a boulder of quartz float found in Summit (Surprise) Creek was 'liberally spangled with gold'. Samples collected by Kurtak and others (1999) along Surprise Creek include panned concentrates that contain up to 3,888 ppb gold, limonite-stained quartz-carbonate float that contains $163 \mathrm{ppb}$ gold, and a piece of malachite-stained schist.

The rocks in Surprise Creek are described by Reed (1938) as quartzite, greenstone, and graphitic and micaceous schists, cut by several quartz veins in the lower valley. Quartz also constitutes a substantial portion of the detrital material in the creek. Dillon and others (1986) map the area as Middle Devonian siliceous clastic rocks.

\section{Alteration:}

\section{Age of mineralization:}

Quaternary.

\section{Deposit model:}

Placer Au (Cox and Singer, 1986; model 39a)

Deposit model number (After Cox and Singer, 1986 or Bliss, 1992):

$39 a$ 
Production Status: Yes

Site Status: Inactive

Workings/exploration:

Surprise Creek was sporadically mined from 1904 through about 1937, typically by booming off the fine material, stacking the rocks along the cut, and shoveling-in the lower 3 feet of the the gravel (Reed, 1938).

Production notes:

There are no production figures available.

\section{Reserves:}

\section{Additional comments:}

\section{References:}

Smith, 1932; Smith, 1933 (B836); Reed, 1938; Heiner and Wolff, 1968; Chipp, 1972; Cobb, 1972 (MF469); Cobb, 1973 (B1374); Cobb, 1976 (OF76-340); Maas, 1987; Bliss and others, 1988; Kurtak and others, 1999; Kurtak and others, 2002.

Primary reference: Reed, 1938

Reporter(s): J.M. Britton (Anchorage)

Last report date: $8 / 9 / 2002$ 


\section{Site name(s): Spring Creek}

Site type: Mine

ARDF no.: WI010

Latitude: 67.5114

Quadrangle: WI C-4

Longitude: 151.5288

Location description and accuracy:

Spring Creek is a small, west-flowing stream that empties into the east side of the middle of Wild Lake. Mining on Spring Creek has occurred principally from its mouth to the forks about 1.5 miles upstream of the mouth. The mine is plotted at an elevation of about 1,300 feet in about the center of the workings. The location is accurate.

\section{Commodities:}

Main: $\mathrm{Au}$

Other:

Ore minerals: Gold

\section{Gangue minerals:}

\section{Geologic description:}

Placer gold was discovered on Spring Creek in 1903, and the creek was mined extensively from 1904 through at least 1937 (Reed, 1938). Several mining operations described by Reed indicate that the depth to bedrock along Spring Creek varied from 5 to 25 feet and occasionally as much as 50 feet. The gravels were frozen and coarse and waterworn with numerous boulders on top of the gravel. The gold was coarse and unworn. It occurred in the lower 3 feet of the gravel and in the upper foot of the bedrock. The gold values determined from mining operations in the 1920's and 1930's were from $\$ 0.18$ to $\$ 0.90$ per square foot of bedrock; the fineness ranged from about 920 to 940 . Maddren noted that $\$ 7,000$ in gold (about 350 ounces) was produced from 1907 to 1909 . Reed (1938) estimated that the total production through 1937 had been $\$ 59,500$ (about 2975 ounces). There are no figures available for any later production.

Kurtak and others (1999) collected six panned-concentrate samples along a 1.2-mile stretch of Spring Creek. The samples contained no visible gold but assays of the six samples averaged 1,260 ppb Au. Reed (1938) described the bedrock in Spring Creek as principally quartzite, and graphitic and greenstone schists. Dillon and others (1986) map the Spring Creek drainage area as Middle Devonian(?) siliceous clastic rocks.

\section{Alteration:}

Age of mineralization:

Quaternary.

\section{Deposit model:}

Placer Au (Cox and Singer, 1986; model 39a)

Deposit model number (After Cox and Singer, 1986 or Bliss, 1992): $39 \mathrm{a}$

Production Status: Yes; small

Site Status: Inactive 


\section{Workings/exploration:}

Spring Creek was worked by opencut and drift mining from 1904 through at least 1937 (Reed, 1938).

Production notes:

Maddren noted that $\$ 7,000$ in gold (about 350 ounces) was produced from 1907 to 1909 . Reed (1938) estimated that the total production through 1937 had been $\$ 59,500$ (about 2975 ounces). There are no figures available for any later production.

\section{Reserves:}

\section{Additional comments:}

\section{References:}

Maddren, 1910; Maddren, 1913; Smith and Mertie, 1930; Smith, 1933 (B836); Reed, 1938; Smith, 1939 (B910A); Smith, 1939 (B917A); Brosge and Reiser, 1960; Heiner and Wolff, 1968; Chipp, 1972; Cobb, 1972 (MF-469); Cobb, 1973 (B1374); Cobb, 1976 (OF76-340); Grybeck, 1977; Dillon and others, 1986; Maas, 1987; Bliss and others, 1988; Kurtak and others, 1999; Kurtak and others, 2002.

Primary reference: Reed, 1938

Reporter(s): J.M. Britton (Anchorage)

Last report date: $8 / 9 / 2002$ 


\title{
Site name(s): Unnamed (between Sirr Creek and Wild Lake)
}

Site type: Occurrence

ARDF no.: WI011

Latitude: 67.5217

\author{
Quadrangle: WI C-4
}

Longitude: 151.5889

Location description and accuracy:

This occurrence is located on a ridge between Sirr Creek and Wild Lake, about 3.8 miles south-southeast of Sirr Mountain. The occurrence is at an elevation of about 2,900 feet about 0.4 mile south-southwest of the center of section 9, T. 31 N,, R. 18 W., of the Fairbanks Meridian. The occurrence is the site of sample 128 of Chipp (1972). Several other samples were collected for about 1.5 miles up the ridge to the north by Chipp, and Kurtak and others (1999). The location is accurate.

\section{Commodities:}

Main: $\mathrm{Ag}, \mathrm{Au}, \mathrm{Cu}, \mathrm{Sb}$

Other: $\mathrm{Pb}, \mathrm{Zn}$

Ore minerals: Galena, chalcopyrite, malachite, pyrite, tetrahedrite, unspecified sulfides

Gangue minerals: Ankerite, calcite, quartz

Geologic description:

This occurrence consists of mineralized quartz veins and altered calcareous schist (Chipp, 1972; Kurtak and others, 1999; Dillon and others, 1981 [AOF 133B]). Samples, including float contain one or more of the following metalliferous minerals: galena, chalcopyrite, malachite, pyrite, and tetrahedrite, and other unspecified sulfides. One sample (Chipp, 1972, sample 128), of altered calcareous-schist with vein quartz and unspecified sulfides contains $0.52 \mathrm{ppm}$ gold, $31 \mathrm{ppm}$ silver, 1\% antimony, 9,700 ppm copper, 2,400 ppm lead, and 1,000 ppm zinc. The rocks in the area are Devonian schist and phyllite (Chipp, 1972).

\section{Alteration:}

Chipp (1972) and Dillon and others (1981 [AOF 133B] ) described some of the samples as altered calcareous-schist, but did not describe the alteration.

Age of mineralization:

\section{Deposit model:}

Polymetallic vein (?) (Cox and Singer, 1986; model 22c)

Deposit model number (After Cox and Singer, 1986 or Bliss, 1992): $22 c(?)$

Production Status: None

Site Status: Inactive

Workings/exploration:

Only surface sampling.

Production notes: 


\section{Reserves:}

Additional comments:

\section{References:}

Chipp, 1972; Dillon and others, 1981 (AOF 133B); Bliss and others, 1988; Kurtak and others, 1999.

Primary reference: Chipp, 1972

Reporter(s): J.M. Britton (Anchorage)

Last report date: $8 / 9 / 2002$ 


\section{Site name(s): Unnamed (south of Pet Lake)}

Site type: Occurrence

ARDF no.: WI012

Latitude: 67.5928

Quadrangle: WI C-4

Longitude: 151.9021

Location description and accuracy:

This occurrence is at an elevation of about 4,350 feet, about 0.2 mile southeast of peak 4816, near the southeast corner of section 13, T. 32 N., R. 20 W., of the Fairbanks Meridian. The location is accurate within about one-half mile.

\section{Commodities:}

Main: $\mathrm{Ag}, \mathrm{Au}, \mathrm{Cu}$

Other: $\mathrm{Mo}, \mathrm{Pb}, \mathrm{Sc}, \mathrm{Ti}, \mathrm{V}, \mathrm{Zn}$

Ore minerals: Bornite, chalcopyrite, galena, malachite, sphalerite

Gangue minerals: Hematite, quartz

\section{Geologic description:}

This occurrence is one of several that define a northeast trending zone of minor copper occurrences that extends northeast for about 5 miles from VABM Allen on the Wiseman C-5 topographic map (also see WI005, 006, 013, 014, and 016). This occurrence was first described by Brosge and Reiser (1960) as copper sulfides, galena and malachite in a quartz vein in Devonian phyllite and siltstone below a thrust plate of Devonian Skajit Limestone. Nearby, Dillon and others (1981, localities 244 and 245 [AOF 133B]) sampled mineralized pebble conglomerate and cross-bedded metasandstone near a facies change from metaclastic to metacarbonate rocks. The pebble conglomerate was malachite-stained and contained disseminated chalcopyrite, sphalerite, and galena. The metasandstone contained sphalerite and abundant hematite. Samples from these two units contain up to 7,000 ppm copper, 10 ppm silver, more than $1 \%$ titanium, 70 ppm scandium, 700 ppm vanadium, 500 ppm zinc, and 100 ppm molybdenum. Kurtak and others (1999) collected two selected bedrock samples of micaceous schist and limestone and a sample of quartz-chlorite schist float that contains bornite, malachite, and possibly galena; one sample has $11 \%$ copper, 17 ppb gold, and 68.9 ppm silver.

\section{Alteration:}

\section{Age of mineralization:}

Deposit model:

Polymetallic vein (?) (Cox and Singer, 1986; model 22c)

Deposit model number (After Cox and Singer, 1986 or Bliss, 1992): $22 \mathrm{c}(?)$

Production Status: None

Site Status: Inactive

Workings/exploration: 
Only surface sampling.

\section{Production notes:}

Reserves:

Additional comments:

See also WI014. This occurrence is located within Gates of the Arctic National Park.

\section{References:}

Cobb, 1972 (MF-469); Cobb, 1976 (OF76-340); Degenhart and others, 1978; Dillon and others, 1981 (AOF 133B); Bliss and others, 1988; Kurtak and others, 1999.

Primary reference: Kurtak and others, 1999

Reporter(s): J.M. Britton (Anchorage)

Last report date: $8 / 9 / 2002$ 


\section{Site name(s): Unnamed (south of Pet Lake)}

Site type: Occurrence

ARDF no.: WI013

Latitude: 67.6060

Quadrangle: WI C-4

Longitude: 151.9062

Location description and accuracy:

This occurrence is about 1.3 miles south-southeast of the east end of Pet Lake. It is in a creek at an elevation of about 3,250 feet, 0.5 mile east of the top of hill 4116, in the SE 1/4 of section 12, T. 32 N., R. 20 W., of the Fairbanks Meridian. The occurrence is the site of sample 348 in Dillon and others (1981). The location is accurate.

\section{Commodities:}

Main: $\mathrm{Cu}, \mathrm{Sb}, \mathrm{Zn}$

Other:

Ore minerals: Chalcopyrite, cuprite, sphalerite(?)

Gangue minerals: Quartz

Geologic description:

Dillon and others (1981, locality 348 [AOF 133B]) describe this occurrence as a mineralized layer 300 meters long and 5 to $250 \mathrm{~cm}$ thick, that is composed mainly of fine-grained quartz that contains chalcopyrite, and sparse cuprite and sphalerite. A single chip sample from outcrop contains $2 \%$ copper, more than $100 \mathrm{ppm}$ antimony, and $20 \mathrm{ppm}$ zinc. The rocks in the area are Devonian, Skajit Limestone and Middle or Upper Devonian black phyllite, dark limestone, and conglomerate (Dillon and others, 1986).

\section{Alteration:}

Age of mineralization:

Deposit model:

Polymetallic replacement deposit (?) (Cox and Singer, 1986; model 19a)

Deposit model number (After Cox and Singer, 1986 or Bliss, 1992):

$19 \mathrm{a}(?)$

Production Status: None

Site Status: Inactive

Workings/exploration:

Only surface sampling.

Production notes:

Reserves:

Additional comments: 
This occurrence is located within Gates of the Arctic National Park.

\section{References:}

Dillon and others, 1981 (AOF 133B); Dillon and others, 1986; Bliss and others, 1988.

Primary reference: Dillon and others, 1981(AOF 133B)

Reporter(s): J.M. Britton (Anchorage)

Last report date: $8 / 9 / 2002$ 


\section{Site name(s): Unnamed (northeast of head of Sheep Creek)}

Site type: Occurrence

ARDF no.: WI014

Latitude: 67.5828

Quadrangle: WI C-4

Longitude: 151.9188

Location description and accuracy:

This occurrence is at an elevation of about 3,500 feet, about 0.1 mile southwest of the center of section 24, T. 32 N., R. 20 W., of the Fairbanks Meridian. The occurrence is the site of sample BM 1533 of Degenhart and others (1978). The location is accurate.

\section{Commodities:}

Main: $\mathrm{Ag}, \mathrm{Cu}$

Other: $\mathrm{Au}, \mathrm{Pb}(?)$

Ore minerals: Azurite, bornite, chalcopyrite, galena(?), malachite

Gangue minerals:

\section{Geologic description:}

This occurrence is one of several that define a northeast trending zone of minor copper occurrences that extends for about 5 miles to the northeast from VABM Allen on the Wiseman C-5 topographic map (also see WI005, 006, 012, 013, and 016). Most of these occurrences consist of malachite, azurite, and chalcopyrite that are along a thrust-fault contact that separates Devonian, Skajit Limestone from underlying chloritic schist (Degenhart and others, 1978). At this location a small pod of copper mineralization, no more than 5 feet in diameter, occurs in marble (Degenhart and others, 1978). A sample, said to be representative of the mineralization contains 5,700 ppm copper, 3.4 ppm silver, and 10 ppb gold. (Degenhart and others, 1978, sample BM1533). It did not contain significant lead, zinc, or molybdenum. Kurtak and others (1999) also described podiform copper mineralization in this area. They collected selected bedrock samples of micaceous schist and limestone, and a float sample of quartz-chlorite schist. The schist samples contains bornite, malachite, and possibly galena; a sample of the schist contains $11 \%$ copper, 17 ppb gold, and 68.9 ppm silver.

Alteration:

Age of mineralization:

Deposit model:

Polymetallic replacement deposit (?) (Cox and Singer, 1986; model 19a)

Deposit model number (After Cox and Singer, 1986 or Bliss, 1992): $19 \mathrm{a}(?)$

Production Status: None

Site Status: Inactive

Workings/exploration:

Only surface sampling. 
Production notes:

Reserves:

Additional comments:

See also WI013.

\section{References:}

Degenhart and others, 1978; Bliss and others, 1988; Kurtak and others, 1999.

Primary reference: Degenhart and others, 1978

Reporter(s): J.M. Britton (Anchorage)

Last report date: $8 / 9 / 2002$ 


\title{
Site name(s): Unnamed (southeast of upper Sheep Creek)
}

Site type: Occurrence

ARDF no.: WI015

Latitude: 67.5164

\author{
Quadrangle: WI C-4
}

Longitude: 151.9438

Location description and accuracy:

This occurrence is at an elevation of about 4,700 feet, about 500 feet west-southwest of the top of hill 4717 in the NE1/4 section 14, T. 31 N., R. 20 W., of the Fairbanks Meridian. The occurrence is the site of sample 11 in Dillon and others (1981 [AOF 133B]). The location is accurate within one-half mile.

\section{Commodities:}

Main: $\mathrm{Cu}, \mathrm{Mo}$

Other: $\mathrm{Pb}$

Ore minerals: Bornite, galena, malachite

Gangue minerals: Quartz

\section{Geologic description:}

This occurrence consists of a stockworks of synmetamorphic(?) quartz veins that cut calcite-quartz schist. The veins contain malachite, bornite, and galena (Dillon and others, 1981, samples 10 and 11 [AOF 133B]). Metasiltstone nearby is malachite stained and contains disseminated, partially oxidized, copper sulfides. A grab sample taken from an outcrop contains up to $1 \%$ copper and $30 \mathrm{ppm}$ molybdenum. The samples do not contain significant lead. The occurrence is near the contact between Middle Devonian(?) siliceous clastic rocks and Devonian, Skajit Limestone (Dillon and others, 1986).

\section{Alteration:}

Oxidation of copper mineral(s).

Age of mineralization:

\section{Deposit model:}

Deposit model number (After Cox and Singer, 1986 or Bliss, 1992):

Production Status: None

Site Status: Inactive

\section{Workings/exploration:}

Only surface sampling.

Production notes:

Reserves:

Additional comments: 


\section{References:}

Dillon and others, 1981 (AOF 133B); Dillon and others, 1986; Bliss and others, 1988.

Primary reference: Dillon and others, 1981

Reporter(s): J.M. Britton (Anchorage)

Last report date: $8 / 9 / 2002$ 


\section{Site name(s): Sheep Creek}

Site type: Occurrence

ARDF no.: WI016

Latitude: 67.5624

Quadrangle: WI C-4

Longitude: 151.9818

Location description and accuracy:

This occurrence is at an elevation of about 3,600 feet, about 1,00 feet northeast of the top of hill 3914, near the southeast corner of section 27, T. 32 N., R. 20 W., of the Fairbanks Meridian. The occurrence is near the midpoint of a mile-long, east-northeast belt defined by the locations of several mineralized samples (Degenhart and others, 1978). It also corresponds to the location of mineralization described by Brosge and Reiser (1960) and by Cobb (1972, MF 469, loc. 7). The location is accurate within one-half mile.

\section{Commodities:}

Main: $\mathrm{Cu}$

Other: $\operatorname{Ag}(?)$

Ore minerals: Azurite, bornite, chalcopyrite, cuprite(?), malachite

Gangue minerals: Quartz

Geologic description:

This occurrence is one of several that define a northeast trending zone of minor copper occurrences that extends for about 5 miles to the northeast from VABM Allen on the Wiseman C-5 topographic map (see also WI005, 006, and 012-014). Mineralization at this site was first described by Brosge and Reiser (1960; Cobb, 1972, locality 7 [MF 469] ), as conglomerate containing unspecified copper sulfides and malachite staining. Degenhart and others (1978) cite minor chalcopyrite, malachite, and azurite in a 5-foot-thick layer of quartz-chlorite schist. The schist underlies Middle Devonian, Skajit Limestone, which in this area is thrust over Upper Devonian shale, phyllite and schist. Degenhart and others (1978) suggested that the quartz-chlorite schist may represent the plane of a thrust fault . A select sample of mineralized talus material, collected about 0.2 mile east of the Brosge and Reiser location, contains 1,920 ppm copper and 4.2 ppm silver but no significant gold, lead, zinc, or molybdenum (Degenhart and others, 1978, sample BM1197). They interpret the mineralization as stratabound although its extent appears to be no more than 20 feet along strike and 5 feet in thickness.

Dillon and others (1981; sample 304 [AOF 133B]) collected a composite rock sample about 0.5 mile west of the Brosge and Reiser's site. It consists of graphitic, chlorite-sericite-quartz schist and vein quartz with disseminated cuprite(?) and malachite; it contains 5,000 ppm copper.

Kurtak and others (1999) found podiform copper mineralization in schist and marble in upper Sheep Creek that could be traced along strike for about 1,700 feet. They also observed chalcopyrite and bornite in quartz veins and in fracture fillings along a marble-schist contact. The orientation of these mineralized veins and fractures is parallel to the bedding of the overlying marble. They collected seven rock samples of float and outcrop, one of which contains an estimated $20 \%$ chalcopyrite. The samples contain $872 \mathrm{ppm}$ to $16.53 \%$ copper, less than 5 to $46 \mathrm{ppb}$ gold, and 0.3 to $78.6 \mathrm{ppm}$ silver.

\section{Alteration:}

Local oxidation of copper minerals.

Age of mineralization: 
Deposit model:

Polymetallic replacement deposit (?) (Cox and Singer, 1986; model 19a)

Deposit model number (After Cox and Singer, 1986 or Bliss, 1992):

$19 \mathrm{a}(?)$

Production Status: None

Site Status: Inactive

Workings/exploration:

Only surface sampling.

Production notes:

Reserves:

Degenhart and others (1978) noted that a few tons of mineralized material with about $0.5 \% \mathrm{Cu}$ may be present.

Additional comments:

See also WI014. This occurrence is located within Gates of the Arctic National Park.

References:

Brosge and Reiser, 1960; Cobb, 1972 (MF-469); Cobb, 1976 (OF76-340); Grybeck, 1977; Degenhart and others, 1978; Dillon and others, 1981 (AOF 133B); Maas, 1987; Bliss and others, 1988; Kurtak and others, 1999.

Primary reference: Degenhart and others, 1978

Reporter(s): J.M. Britton (Anchorage)

Last report date: $8 / 9 / 2002$ 


\section{Site name(s): Lynx Creek}

Site type: Occurrence

ARDF no.: WI017

Latitude: 67.5030

Quadrangle: WI C-4

Longitude: 151.5461

Location description and accuracy:

Lynx Creek is not named on the Wiseman C-4 topographic map. Based on its description by Reed (1938), Lynx Creek is inferred to be a small drainage that flows into the east side of Wild Lake about 0.8 mile southwest of Spring Creek. The occurrence is at an elevation of about 1,250 feet near the mouth of Lynx Creek. The location is accurate within $1 / 2$ mile.

\section{Commodities:}

Main: $\mathrm{Au}$

Other:

Ore minerals: Gold

\section{Gangue minerals:}

Geologic description:

Reed (1938) notes reports of good placer gold prospects near the mouth of Lynx Creek although no mining had been done. In Reed's judgment, the appearance of the creek suggested that it was unlikely that any significant concentration of gold had taken place. No other information is available.

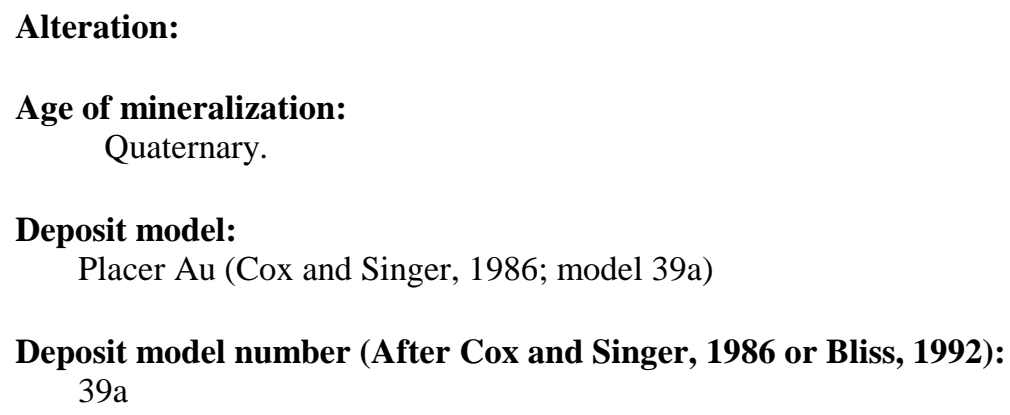

Production Status: None

Site Status: Inactive

\section{Workings/exploration:} Prospecting only.

\section{Production notes:}

Reserves:

Additional comments: 


\section{References:}

Reed, 1938; Cobb, 1976 (OF76-340); Cobb, 1981 (OF81-732).

Primary reference: Reed, 1938

Reporter(s): J.M. Britton (Anchorage)

Last report date: $8 / 9 / 2002$ 


\section{Site name(s): Rocky Point}

Site type: Occurrence

ARDF no.: WI018

Latitude: 67.5209

Quadrangle: WI C-4

Longitude: 151.5567

Location description and accuracy:

This occurrence is on the west side of Wild Lake about 1.5 miles from the north end of the lake, opposite the mouth of Surprise Creek. The occurrence is at an elevation of about 1,250 feet, about 0.5 mile southwest of the center of section 10, T. 31 N., R. 18 W., of the Fairbanks Meridian. The location is accurate.

\section{Commodities:}

Main: $\mathrm{Cu}$

Other:

Ore minerals: Malachite

Gangue minerals: Quartz

Geologic description:

This occurrence consists of sparse malachite in a quartz vein (Chipp, 1972). An analysis of a sample produced no significant metal values. The rocks in the area are Middle Devonian(?) siliceous clastic rocks (Dillon and others, 1986). No other information is available.

\section{Alteration:}

Age of mineralization:

Deposit model:

Deposit model number (After Cox and Singer, 1986 or Bliss, 1992):

Production Status: None

Site Status: Inactive

Workings/exploration:

Production notes:

Reserves:

Additional comments:

References:

Chipp, 1972; Cobb, 1976 (OF76-340); Dillon and others, 1986; Maas, 1987.

Primary reference: Chipp, 1972 
Reporter(s): J.M. Britton (Anchorage)

Last report date: $8 / 9 / 2002$ 


\section{Site name(s): Sirr Creek; North Fork Seward Creek}

Site type: Mine

ARDF no.: WI019

Latitude: 67.5345

Quadrangle: WI C-4

Longitude: 151.6374

Location description and accuracy:

Sirr Creek is a south-flowing tributary of Seward Creek that is about 2 miles west of Wild Lake. As described by Reed (1938), Sirr Creek was known as the North Fork Seward Creek in the 1930's and only the eastern fork was called Sirr Creek. This location of the workings is uncertain and the mine is arbitrarily plotted on Sirr Creek at an elevation of about 1,750 feet.

\section{Commodities:}

Main: Au

Other:

Ore minerals: Gold

Gangue minerals:

Geologic description:

Reed (1938) reported that there was extensive prospecting and a little placer mining on Sirr Creek in the early 1900's. The rocks in the area are Devonian phyllite and schist (Chipp, 1972). No other information is available.

\section{Alteration:}

Age of mineralization:

Quaternary.

Deposit model:

Placer Au (Cox and Singer, 1986; model 39a)

Deposit model number (After Cox and Singer, 1986 or Bliss, 1992):

$39 \mathrm{a}$

Production Status: Undetermined.

Site Status: Inactive

\section{Workings/exploration:}

Prospecting and a little mining.

Production notes:

Reserves:

Additional comments: 


\section{References:}

Reed, 1938; Chipp, 1972; Cobb, 1972 (MF-469); Cobb, 1976 (OF76-340); Maas, 1987; Bliss and others, 1988 .

Primary reference: Reed, 1938

Reporter(s): J.M. Britton (Anchorage)

Last report date: $8 / 9 / 2002$ 


\title{
Site name(s): Unnamed (south of upper Seward Creek)
}

Site type: Occurrence

ARDF no.: WI020

Latitude: 67.5084

\author{
Quadrangle: WI C-4
}

Longitude: 151.7514

Location description and accuracy:

This occurrence is on a ridge about 1 mile south of the pass between the head of Seward Creek and the valley of Allen River. The occurrence is at an elevation of about 3,200 feet, about 0.5 mile east-southeast of the center of section 15, T. 31 N., R.15 W., of the Fairbanks Meridian. The location is accurate within onehalf mile.

\section{Commodities:}

Main: $\mathrm{Cu}$

Other:

Ore minerals: Chalcopyrite(?), copper sulfides (unspecified), malachite, tetrahedrite(?)

Gangue minerals: Quartz(?)

Geologic description:

Brosge and Reiser (1960) describe this occurrence as copper sulfides and malachite staining in Devonian phyllite and siltstone. Kurtak and others (2002) sampled an outcrop of dolomite in this area that contains about $1 \%$ pyrite, but an analysis showed no significant metal values. They note that this occurrence is similar to several other unspecified, small, podiform copper occurrences in the Wild Lake area. They are extremely small, podiform, and contain chalcopyrite, tetrahedrite, and/or malachite. No other information about this occurrence is available.

\section{Alteration:}

Local malachite staining.

Age of mineralization:

Deposit model:

Deposit model number (After Cox and Singer, 1986 or Bliss, 1992):

Production Status: None

Site Status: Inactive

Workings/exploration:

Only surface sampling.

Production notes:

Reserves:

Additional comments: 


\section{References:}

Brosge and Reiser, 1960; Berg and Cobb, 1967; Cobb, 1972 (MF-469); Cobb, 1976 (OF76-340); Bliss and others, 1988; Kurtak and others, 2002.

Primary reference: Brosge and Reiser, 1960

Reporter(s): J.M. Britton (Anchorage)

Last report date: $8 / 9 / 2002$ 


\title{
Site name(s): Unnamed (east of the north end of Wild Lake)
}

Site type: Occurrence

ARDF no.: WI021

Latitude: 67.5364

\author{
Quadrangle: WI C-3
}

Longitude: 151.4849

Location description and accuracy:

This occurrence is located on a ridge about 1 mile east of Wild Lake, between the head of Surprise Creek and the north end of Wild Lake. The occurrence is at an elevation of about 3,000 feet in the NE1/4 SE1/4 section 2, T. 31 N., R. 18 W., of the Fairbanks Meridian. Several sample locations (Chipp, 1972, samples 116 and 117; Kurtak and others, 1999, samples 46, 47, and 48) were collected for about 4,000 feet northeast from this occurrence. The location is accurate.

\section{Commodities:}

Main: $\mathrm{Cu}$

Other: $\mathrm{Ag}, \mathrm{Au}$

Ore minerals: Bornite, chalcopyrite, malachite

Gangue minerals: Ankerite(?), calcite, quartz

Geologic description:

This occurrence consists of quartz-calcite-ankerite(?) veins with varying amounts of bornite, malachite, or chalcopyrite (Chipp, 1972, sample 116 and 117; Kurtak and others, 1999, sample 46). One of Chipp's samples contains 2,700 ppm copper, 0.14 ppm gold, and $3.1 \mathrm{ppm}$ silver. Sample of quartz veins collected by Kurtak and others (1999, samples 46, 47, and 48 contain copper minerals but analysis of these samples showed no significant metal values. The rocks in the area are Devonian schist and phyllite (Dillon and others, 1986). No other information is available.

\section{Alteration:}

Age of mineralization:

\section{Deposit model:}

Polymetallic vein (?) (Cox and Singer, 1986; model 22c)

Deposit model number (After Cox and Singer, 1986 or Bliss, 1992): $22 c(?)$

Production Status: None

Site Status: Inactive

Workings/exploration:

Only surface sampling.

Production notes:

Reserves: 
Additional comments:

References:

Chipp, 1972; Dillon and others, 1986; Bliss and others, 1988; Kurtak and others, 1999.

Primary reference: Chipp, 1972

Reporter(s): J.M. Britton (Anchorage)

Last report date: $8 / 9 / 2002$ 


\section{Site name(s): Twocent Creek}

Site type: Occurrence

ARDF no.: WI022

Latitude: 67.5294

Quadrangle: WI C-3

Longitude: 151.4042

Location description and accuracy:

Twocent Creek is not named on the Wiseman C-3 topographic map. Based on descriptions by Reed (1938), Twocent Creek, is probably the short, west tributary of Flat Creek whose mouth is about 0.2 mile south of the junction of Deadman and Flat Creeks. Another, less likely, possibility is that Twocent Creek is one of two short, west tributaries to Flat Creek about a mile farther downstream. The coordinates are the most likely locality in the NW1/4 section 8, T. 31 N., R. 17 W., of the Fairbanks Meridian. The location is accurate within 1 mile.

\section{Commodities:}

Main: $\mathrm{Au}$

Other:

Ore minerals: Gold

Gangue minerals:

Geologic description:

Reed (1938) reported that miners in the early 1900's could pan small amounts of gold from this creek -two cents worth per pan at the old $\$ 20.67$ per ounces price of gold. Dillon and others (1986) map the rocks in this area as Devonian Hunt Fork Shale. No other information is available.

\section{Alteration:}

Age of mineralization:

Quaternary.

Deposit model:

Placer Au (Cox and Singer, 1986; model 39a)

Deposit model number (After Cox and Singer, 1986 or Bliss, 1992):

$39 \mathrm{a}$

Production Status: None

Site Status: Inactive

Workings/exploration:

Apparently only prospecting.

Production notes:

Reserves: 
Additional comments:

\section{References:}

Reed, 1938; Cobb, 1976 (OF76-340); Cobb, 1981 (OF81-732); Dillon and others, 1986.

Primary reference: Reed, 1938

Reporter(s): J.M. Britton (Anchorage)

Last report date: $8 / 9 / 2002$ 


\section{Site name(s): Unnamed (east of upper Wild Lake)}

Site type: Occurrence

ARDF no.: WI023

Latitude: 67.5383

Quadrangle: WI C-3

Longitude: 151.4570

Location description and accuracy:

This occurrence is about 1.8 miles east of the upper end of Wild Lake and 1.5 miles west-northwest of the junction of Deadman and Flat Creeks. The occurrence is on a 3,800-foot knoll, 0.2 mile northeast of the center of section 1, T. 31 N., R. 18 W., of the Fairbanks Meridian. The location is accurate within one-half mile.

\section{Commodities:}

Main: $\mathrm{Cu}$

Other:

Ore minerals: Malachite, unspecified copper sulfides

Gangue minerals:

Geologic description:

Brosge and Reiser (1960) noted copper sulfides and malachite staining in Devonian calcareous schist. No other information is available.

Alteration:

Oxidation of copper mineral(s).

Age of mineralization:

Deposit model:

Deposit model number (After Cox and Singer, 1986 or Bliss, 1992):

Production Status: None

Site Status: Inactive

Workings/exploration:

Only surface sampling.

Production notes:

Reserves:

Additional comments:

References:

Brosge and Reiser, 1960; Cobb, 1972 (MF-469); Cobb, 1976 (OF76-340); Bliss and others, 1988. 
Primary reference: Brosge and Reiser, 1960

Reporter(s): J.M. Britton (Anchorage)

Last report date: $8 / 9 / 2002$ 


\section{Site name(s): Unnamed (west of upper Flat Creek)}

Site type: Occurrence

ARDF no.: WI024

Latitude: 67.5421

Quadrangle: WI C-3

Longitude: 151.4394

Location description and accuracy:

This occurrence is about a mile west of upper Flat Creek. It is at an elevation of about 3,550 feet, 0.3 mile north of the top of hill 3915, in the NW1/4 section 6, T. 31 N., R. 17 W., of the Fairbanks Meridian. The location is accurate.

\section{Commodities:}

Main: $\mathrm{As}, \mathrm{Au}(?)$

Other:

Ore minerals: Arsenopyrite, pyrite

Gangue minerals: Limonite, quartz

\section{Geologic description:}

This occurrence consists of quartz veins that contain arsenopyrite, and trace amounts of pyrite, and limonite (Kurtak and others, 1999). A random chip sample from outcrop contains $63 \mathrm{ppb}$ gold and $162 \mathrm{ppm}$ arsenic. The rocks in the area are Devonian, siliceous clastic, chloritic and carbonate rocks (Dillon and others, 1986). No other information is available.

Alteration:

Iron-oxide alteration.

Age of mineralization:

Deposit model:

Deposit model number (After Cox and Singer, 1986 or Bliss, 1992):

Production Status: None

Site Status: Inactive

Workings/exploration:

Only surface sampling.

Production notes:

Reserves:

Additional comments:

References:

Dillon and others, 1986; Kurtak and others, 1999. 
Primary reference: Kurtak and others, 1999

Reporter(s): J.M. Britton (Anchorage)

Last report date: 8/9/2002 


\section{Site name(s): Mascot Creek}

Site type: Mine

ARDF no.: WI025

Latitude: 67.5087

Quadrangle: WI C-2

Longitude: 150.5439

Location description and accuracy:

Mascot Creek flows south about 7 miles to the Glacier River. The coordinates are at about the midpoint of a 3-mile-long stretch of placer mining on Mascot Creek; it is in the SW1/4 of section 18, T. 31 N., R. 13 W., of the Fairbanks Meridian. The location is accurate.

\section{Commodities:}

Main: $\mathrm{Au}$

Other:

Ore minerals: Gold

\section{Gangue minerals:}

\section{Geologic description:}

Most of the mining on Mascot Creek has been along a 3-mile stretch of the creek, downstream from the forks located approximately 7 miles above the mouth. Mining and prospecting above and below this section of the creek has generally proved to be unproductive. The gold occurs both in the modern stream channel and in high channels. Most of the gold has been taken from the modern stream channel. The gravel is waterworn and fine with few boulders; none of the gravel is frozen. The gravel in the modern channel generally is 0.5 to 3 feet thick. The relative ease with which these thin gravels could be mined made Mascot Creek one of the more profitable placer creeks in the district.

The gold in the modern channel is just above and below the bedrock surface; it typically is coarse and well worn. Nuggets with values up to $\$ 100$ (5 oz) have been recovered (Maddren, 1913). In one location near the upper end of the mined area, the gold was $90 \%$ coarse and $10 \%$ fine. Fineness ranged from about 942 to 977 . Reed (1938) estimated that the value of the ground being mined in the modern channel in 1938 was $\$ 1.25$ to nearly $\$ 7$ per square foot of bedrock.

Gold also occurs in remnants of a high channel on Mascot Creek. These remnants typically are along the right limit (west side) of the creek and a few tens of feet above the modern channel. Reed (1938) described one of these remnants as about 100 feet long and 10 feet wide; another was about 30 feet above the modern stream.

According to Reed (1938), the bedrock in Mascot Creek is graphitic to quartz schist. The quartz schist is reddish from iron staining; its relation to the placer gold is unknown. According to Schrader (1904), mica schist on bedrock contains quartz stringers and a few porphyry dikes. Bliss and others (1988) speculated that the gold might be derived from these quartz stringers. Kurtak and others (1999) described the bedrock of Mascot Creek as quartz-mica schist, graphitic schist, phyllite, siliceous mudstone and schistose quartzite.

\section{Alteration:}

Age of mineralization:

Quaternary.

\section{Deposit model:}

Placer Au (Cox and Singer, 1986; model 39a) 
Deposit model number (After Cox and Singer, 1986 or Bliss, 1992):

$39 a$

Production Status: Yes; small

Site Status: Probably inactive

\section{Workings/exploration:}

The Mascot Creek placer was extensively mined and prospected, mostly along a 3-4 mile section of the modern channel beginning about 3 miles above the mouth. Most mining was by ground sluicing and shoveling in. Although bedrock beneath the placer gravels in this part of the creek was thought to be about 20 feet deep, thawed gravel apparently prevented the prospect shafts from reaching bedrock. The last extensive mining reported on the creek was in the 1980's (Kurtak and others, 1999). The creek is considered to be essentially mined out except for perhaps a few small pockets. Some very small scale mining (hand methods?) directed at these pockets appears to have continued into the mid-1990's (Kurtak and others, 1999).

\section{Production notes:}

Maddren reported total gold production through 1910 as about \$150,000 (approx. 7,900 oz.). Mining has continued intermittently since that time, but there is no record of this later production.

\section{Reserves:}

\section{Additional comments:}

\section{References:}

Schrader, 1904; Brooks, 1908; Maddren, 1910; Maddren, 1913; Smith, 1933 (B836); Smith, 1936; Reed, 1938; Brosge and Reiser, 1960; Heiner and Wolff, 1968; Cobb, 1972 (MF-469); Cobb, 1976 (OF76-340); Grybeck, 1977; Cobb, 1981 (OF81-732); Eakins and others, 1983; Maas, 1987; Bliss and others, 1988; Kurtak and others, 1999.

Primary reference: Reed, 1938

Reporter(s): J.M. Britton (Anchorage)

Last report date: $8 / 9 / 2002$ 


\section{Site name(s): Unnamed (east of head of Bonanza Creek)}

Site type: Occurrence

ARDF no.: WI026

Latitude: 67.5745

Quadrangle: WI C-2

Longitude: 150.7903

Location description and accuracy:

This occurrence is about 1 mile southeast of the small lake at the head of Bonanza Creek; it is on the west slope of the ridge between Bonanza and Conglomerate Creeks. The occurrence is at elevation of about 3,300 feet, about 0.4 mile north-northwest of the center of section 25, T. 32 N., R. 15 W., of the Fairbanks Meridian. The location is accurate within about three-quarters of a mile.

\section{Commodities:}

Main: $\mathrm{Pb}, \mathrm{Zn}$

Other: As

Ore minerals: Galena, sphalerite

Gangue minerals: Ankerite(?), quartz, siderite(?)

Geologic description:

Brosge and Reiser (1960) originally describe this occurrence as a galena-bearing quartz vein in Middle(?) Devonian slate, phyllite and siltstone. Kurtak and others (1999) describe a 35-foot-wide by 150-foot-long area of rusty-weathering, intensely fractured and dolomitized metamorphic rock that they tentatively interpret as a northwest-trending shear zone. The rock is cut by numerous quartz veinlets containing traces of galena, sphalerite, and possibly ankerite(?). A sample of quartz float downslope from the outcrop contains traces of galena, sphalerite, siderite, and ankerite, and 3,510 ppm zinc, 3,438 ppm lead, and 3,772 ppm arsenic.

\section{Alteration:}

Rusty weathering, intense fracturing, and dolomitization.

Age of mineralization:

Deposit model:

Polymetallic vein (?) (Cox and Singer, 1986; model 22c)

Deposit model number (After Cox and Singer, 1986 or Bliss, 1992): $22 c(?)$

Production Status: None

Site Status: Inactive

Workings/exploration:

Only surface sampling.

Production notes: 


\section{Reserves:}

Additional comments:

See also unnamed occurrences WI001 and WI002. This occurrence is located in Gates of the Arctic National Park.

\section{References:}

Brosge and Reiser, 1960; Cobb, 1972 (MF-469); Cobb, 1976 (OF76-340); Bliss and others, 1988; Kurtak and others, 1999.

Primary reference: Kurtak and others, 1999

Reporter(s): J.M. Britton (Anchorage)

Last report date: $8 / 9 / 2002$ 


\section{Site name(s): Vermont Creek; Right Fork}

Site type: Mine

ARDF no.: WI027

Latitude: 67.5146

Quadrangle: WI C-1

Longitude: 150.1354

Location description and accuracy:

Vermont Creek and its tributary, Right Fork, flow east into the Hammond River. Vermont Creek heads on Vermont Dome and Right Fork heads in Vermont Pass. The placer deposits on Vermont Creek extend from the valley of the Hammond River, up Vermont Creek to the fork, then up the Right Fork for 0.5 to 0.7 mile. Placer gold is not known to occur on Vermont Creek above its junction with Right Fork. The coordinates are the junction of Right Fork and Vermont Creek. The location is accurate.

\section{Commodities:}

Main: $\mathrm{Au}$

Other:

Ore minerals: Gold, pyrite, stibnite

\section{Gangue minerals:}

\section{Geologic description:}

Gold was discovered on Vermont Creek August 25, 1901. Maddren reported that \$172,000 (about 9,050 ounces) were produced from 1901 through 1909. Eden (2000) reports that a total of 9,145.40 ounces of gold were produced from Vermont Creek between 1904 and 1999. Kurtak and others (2002) estimate that 11,230 oz. of gold were produced between 1901 and 1983. Mining is reported as late as 1983 (Bundtzen and others, 1984) and there was some mining in 1992 (Swainbank and others, 1993).

Placer gold occurs in the modern stream beds of Vermont Creek and Right Fork, and in deep buried channels in lower Vermont Creek. Maddren, (1913). Reed (1938) suggests that the deep channels may in part be continuous with bench deposits of the Hammond River.

Auriferous shallow gravels on Right Fork extend continuously from the lower 0.5 to 0.7 mile of Right Fork, and continues along Vermont Creek below the mouth of Right Fork for about 0.2 to 0.5 mile (about one or two claim lengths). Right Fork contains about 3 feet of gravel, but the width of the gravel is restricted due to the narrowness of the valley bottom. In Vermont Creek below the mouth of Right Fork, the gravels are covered by 6 to 8 feet of muck; the pay channel increases in width to 200 to 400 feet and in thickness to 4 or 5 feet. The pay channel consists of coarse-grained, poorly sorted and subangular gravel, lying on soft micaceous schist (Reed, 1938). The gold in Vermont Creek is on, and in the top few inches of, the bedrock. The gold forms few small nuggets; it is mostly fine. According to Reed (1938) the value of the ground in these shallow gravels was about $\$ 0.13$ per square foot of bedrock (gold at $\$ 35.00$ per ounce). The gravel contains considerable pyrite.

On lower Vermont Creek the gravels become deeper, and Maddren (1913) thought that the lower 0.5 miles of auriferous gravel could, at least in part, be continuous with bench deposits of the Hammond River. He also suggests that the gold probably was derived from the drainage area of Vermont Creek. Reed (1938) indicated that the deep channel was about 0.2 mile long, along the left limit of lower Vermont Creek. The gravels in these deposits are frozen and 30 to 90 feet deep. Reed (1938) noted that gravel on the dumps was fine, and waterworn, with few boulders. The gold in these deposits is rounded and mostly coarse; several nuggets more than 10 ounces in weight have been recovered. There are unconfirmed reports that the value of the ground in these deep gravels may have run as high a $\$ 5$ per square foot of bedrock (gold at $\$ 35,00$ per ounce) (Reed, 1938). 
Maddren (1913) identified quartz veinlets along joint surfaces in bedrock on upper Right Fork; he noted that at least one of these veinlets contained sulfides as well as specks and flakes of free gold. A cobble-size boulder of gold quartz with stibnite and about $1 \%$ gold was found by local placer miners (Dillon, 1982). The fineness of the gold from Vermont Creek is 892 to 952, with a median of 928 (Mosier and Lewis, 1986).

\section{Alteration:}

Age of mineralization:

Quaternary.

\section{Deposit model:}

Placer Au (Cox and Singer, 1986; model 39a)

\section{Deposit model number (After Cox and Singer, 1986 or Bliss, 1992): $39 \mathrm{a}$}

Production Status: Yes; small

Site Status: Inactive

\section{Workings/exploration:}

The shallow creek gravels were mined by hand methods and open-cuts. Some of the overburden was removed by hydraulicking. The deep, frozen deep gravels on lower Vermont Creek were drift mined.

\section{Production notes:}

Gold was discovered on Vermont Creek August 25, 1901. Maddren reported that \$172,000 (about 9,050 ounces) were produced from 1901 through 1909. Eden (2000) reports that a total of 9,145.40 ounces of gold were produced from Vermont Creek between 1904 and 1999. Kurtak and others (2002) estimate that 11,230 oz. of gold were produced between 1901 and 1983. Mining is reported as late as 1983 (Bundtzen and others, 1984) and there was some mining in 1992 (Swainbank and others, 1993).

\section{Reserves:}

\section{Additional comments:}

\section{References:}

Schrader, 1904; Brooks, 1908; Maddren, 1910; Maddren, 1913; Brooks, 1915; Brooks, 1918; Wimmler, 1925; Smith, 1930 (B810); Smith, 1932; Smith, 1933 (B836); Smith, 1937; Reed, 1938; Smith, 1938; Brosge and Reiser, 1960; Heiner and Wolff, 1968; Cobb, 1972 (MF-469); Cobb, 1973 (B1374); Mulligan, 1974; Cobb, 1976 (OF76-340); Grybeck, 1977; Dillon, 1982; Eakins and others, 1983; Bundtzen and others, 1984; Eakins and others, 1985; Maas, 1987; Bliss and others, 1988; Bundtzen and others, 1988; Bundtzen and others, 1992; Swainbank and others, 1993; Kurtak and others, 1999; Eden, 2000; Kurtak and others, 2002.

Primary reference: Maddren, 1913

Reporter(s): J.M. Britton (Anchorage)

Last report date: $8 / 9 / 2002$ 


\section{Site name(s): Vermont Dome}

Site type: Occurrence

ARDF no.: WI028

Latitude: 67.5206

Quadrangle: WI C-1

Longitude: 150.2292

Location description and accuracy:

This occurrence is on the south ridge of Vermont Dome, about 0.5 mile south of the summit. Mulligan (1974) described the location as near the crest of the spur that extends southward from the summit of the Dome. The occurrence is at an elevation of about 3,550 feet on this spur. The location is accurate within one-half mile.

\section{Commodities:}

Main: $\mathrm{Cu}$

Other: $\mathrm{Pb}(?), \mathrm{Zn}$

Ore minerals: Copper sulfides, malachite, pyrite(?)

Gangue minerals: Goethite, quartz

Geologic description:

Brosge and Reiser (1960) describe this occurrence as unidentified copper sulfides and malachite stains in Devonian phyllite and siltstone. Mulligan (1974) noted green-stained, light-brown float of quartz vein material with traces of copper, zinc, and iron sulfides, and tiny pods of goethite, along fracture planes in schist fragments found in talus. Eden (2000) collected samples, mostly float, of locally iron-stained quartz on the south side of Vermont Dome. One sample was weakly anomalous in $\mathrm{Cu}$ and another weakly anomalous in $\mathrm{Pb}$. His mapping identifies the rocks in the area as Upper Devonian, gray-black phyllite and pelitic mica schist of the Beaucoup Formation. Kurtak and others (2002) report gem-quality quartz near this site.

\section{Alteration:}

Iron oxides noted.

Age of mineralization:

Deposit model:

Deposit model number (After Cox and Singer, 1986 or Bliss, 1992):

Production Status: None

Site Status: Inactive

Workings/exploration:

Production notes:

Reserves:

Additional comments: 


\section{References:}

Brosge and Reiser, 1960; Cobb, 1972 (MF-469); Mulligan, 1974; Cobb, 1976 (OF76-340); Grybeck, 1977; Cobb, 1981 (OF81-732); Maas, 1987; Bliss and others, 1988; Kurtak and others, 1999; Eden, 2000; Kurtak and others, 2002.

Primary reference: Mulligan, 1974

Reporter(s): J.M. Britton (Anchorage)

Last report date: $8 / 9 / 2002$ 


\section{Site name(s): Washington Creek}

Site type: Mine

ARDF no.: WI029

Latitude: 67.5239

Quadrangle: WI C-1

Longitude: 150.3136

Location description and accuracy:

Washington Creek, an eastern tributary to Glacier River, originates on the south flank of Dusty Mountain. It flows flows southwest and then west to join Glacier River about 5 miles west-southwest of Vermont Dome. About 2.5 miles west-southwest of Vermont Dome, Washington Creek is joined by an unnamed, northwesterly flowing tributary that heads against the divide at the heads of Acme Creek and Montana Gulch. The center of this placer is near the mouth of this southeast, headwater tributary to Washington Creek; it is in the SW1/4 section 7, T. 31 N. , R. 12 W., of the Fairbanks Meridian. The placers extend for about a mile upstream and a mile downstream. The location is accurate.

\section{Commodities:}

Main: $\mathrm{Au}$

Other:

Ore minerals: Gold, magnetite, pyrite

Gangue minerals:

\section{Geologic description:}

Maddren (1913) reports that gold was discovered on Washington Creek in August, 1902, and that production between 1902 and 1909 was about \$5,000 (approximately 260 ounces). Maddren reports that while some coarse, smooth gold was found in the gravels of Washington Creek, the amount of gold was insufficient to encourage serious mining. Reed (1938) reports some mining in the present stream bed from 1900 to 1910, but notes that the amount of gold recovered was not sufficient to warrant continued work. Heavy equipment for mining was being moved to Washington Creek from Mascot Creek in 1982 or 1983 (Bliss and others, 1988). Shafts were sunk by early miners to prospect for high channels along the lower creek but the results are not known. Brosge and Reiser (1972) collected a stream-sediment sample from Washington Creek that contains 700 to $3000 \mathrm{ppm}$ antimony. Kurtak and others (1999) collected several pannedconcentrate samples from Washington Creek that contain traces of pyrite and magnetite, but no visible gold. The rocks in the area are black siltstone and phyllite (Dillon and others, 1986).

\section{Alteration:}

Age of mineralization:

Quaternary.

\section{Deposit model:}

Placer Au (Cox and Singer, 1986; model 39a)

Deposit model number (After Cox and Singer, 1986 or Bliss, 1992): $39 \mathrm{a}$

Production Status: Yes 
Site Status: Inactive

Workings/exploration:

The modern stream bed was mined by hand methods, including open cuts and booming and shoveling (Reed, 1938). High channels were explored by prospect shafts and were possibly drift mined.

Production notes:

Maddren (1913) reports that gold was discovered on Washington Creek in August, 1902, and that production between 1902 and 1909 was about \$5,000 (approximately 260 ounces).

\section{Reserves:}

\section{Additional comments:}

\section{References:}

Schrader, 1904; Maddren, 1910; Maddren, 1913; Reed, 1938; Heiner and Wolff, 1968; Brosge and Reiser, 1972; Cobb, 1972 (MF-469); Mulligan, 1974; Cobb, 1976 (OF76-340); Dillon, 1982; Dillon and others, 1986; Maas, 1987; Bliss and others, 1988; Kurtak and others, 1999.

Primary reference: Reed, 1938

Reporter(s): J.M. Britton (Anchorage)

Last report date: $8 / 9 / 2002$ 


\section{Site name(s): Canyon Creek}

Site type: Occurrence

ARDF no.: WI030

Latitude: 67.5317

Quadrangle: WI C-1

Longitude: 150.1107

Location description and accuracy:

Canyon Creek is long, southeasterly-flowing tributary to Hammond River. Its mouth is about 2.75 miles southwest of Jennie Creek Lake. This gold occurrence is on lower Canyon Creek, in the NE1/4 section 12, T. 31 N., R. 12 W., of the Fairbanks Meridian. The location is accurate within 1 mile.

\section{Commodities:}

Main: $\mathrm{Au}$

Other:

Ore minerals: Gold

Gangue minerals:

Geologic description:

Mulligan(1974) reported that trace amounts of gold had been found along Lower Canyon Creek, and that the upper valley appears favorable for placer gold.

\section{Alteration:}

Age of mineralization:

Quaternary.

Deposit model:

Placer Au (Cox and Singer, 1986; model 39a)

Deposit model number (After Cox and Singer, 1986 or Bliss, 1992):

$39 \mathrm{a}$

Production Status: Undetermined.

Site Status: Probably inactive

Workings/exploration:

Production notes:

Reserves:

Additional comments:

References:

Mulligan, 1974; Cobb, 1976 (OF76-340); Maas, 1987. 
Primary reference: Mulligan, 1974

Reporter(s): J.M. Britton (Anchorage)

Last report date: $8 / 9 / 2002$ 


\section{Site name(s): Slisco Bench}

Site type: Mine

ARDF no.: WI031

Latitude: 67.5105

Quadrangle: WI C-1

Longitude: 150.1114

Location description and accuracy:

The Slisco Bench placer mine is located along the west side of Hammond River about 0.2 mile southwest of the mouth of Vermont Creek. The mine is 0.3 mile east-southeast of the center of section 13, T. 31 N., R. $11 \mathrm{~W}$., of the Fairbanks Meridian. It marks the north end of a reported buried channel that may extend a mile to the south. The location is accurate.

\section{Commodities:}

Main: $\mathrm{Au}$

Other:

Ore minerals: Gold

\section{Gangue minerals:}

Geologic description:

The Slisco Bench deposit is one of a number of bench placers in the valley of the Hammond River. Silverado Mines, the current (2000) owner of most of the property in the vicinity, reports that the Slisco Bench was discovered in the late 1920's and that a small amount of mining was done in the years between the discovery and 1935. Additional mining also occurred in the 1960's. Drilling by Silverado in 1995 intersected gold-bearing gravel in a buried channel beneath 60 to 200 feet of frozen gravel (Silverado Mines website: www.silverado.com). Silverado speculates that the Slisco Bench channel may extend from its shallow north end just south of Vermont Creek, as much as 5000 feet to the south; however, much of this interval is unexplored.

\section{Alteration:}

\section{Age of mineralization:}

Quaternary.

\section{Deposit model:}

Placer Au (Cox and Singer, 1986; model 39a)

Deposit model number (After Cox and Singer, 1986 or Bliss, 1992): $39 \mathrm{a}$

Production Status: Yes

Site Status: Probably inactive

Workings/exploration:

Small-scale mining occurred in the late-1920's, possibly in the early 1930's, and again in the 1960's. Silverado reports that 63 exploratory drill holes were drilled in 1995 (www.silverado.com). 
Production notes:

\section{Reserves:}

In a Silverado Mines press release, dated Oct. 23, 1998, the Slisco Bench placer was said to have a gold resource of 29,715 ounces in all classifications. Current (2000) information from Silverado's website indicates the reserves (of all classifications) at the Slisco Bench placer, are 31,099 ounces of gold. This figure does not include an inferred geologic

potential for an additional 50,000 to 150,000 ounces of gold (Silverado Gold Mines, Ltd. website, www. silverado.com).

\section{Additional comments:}

See also Hammond River (WI103).

\section{References:}

Bundtzen and others, 1994; Bundtzen and others, 1996; Eden, 2000; Kurtak and others, 2002.

Primary reference: This record

Reporter(s): J.M. Britton (Anchorage)

Last report date: $8 / 9 / 2002$ 


\section{Site name(s): Friday the 13th Pup}

Site type: Occurrence

ARDF no.: WI032

Latitude: 67.5109

Quadrangle: WI C-1

Longitude: 150.1491

Location description and accuracy:

'Friday the 13th Pup' creek is not show on the topographic map but it is a short, northwest tributary to Right Fork Creek; its mouth is about 0.5 mile upstream from the mouth of Right Fork Creek. The occurrence is at an elevation of about 1,900 feet on the northwest side of Right Fork, about 0.3 mile southeast of the center of section 14, T. 31 N., R 12 W., of the Fairbanks Meridian. The location is accurate.

\section{Commodities:}

Main: $\mathrm{Au}$

Other: $\mathrm{As}, \mathrm{Sb}$

Ore minerals: Arsenopyrite, gold, pyrite, pyrrhotite, stibnite

Gangue minerals: Ankerite, calcite, dolomite, quartz

\section{Geologic description:}

This occurrence consists of randomly-spaced veins and veinlets in phyllite exposed in bluff faces (Kurtak and others, 1999). Eighteen veins occur in one 100-foot-wide exposure of the phyllite. The veins average about 0.5 inches in width; they generally strike about $\mathrm{N} 60 \mathrm{~W}$ and dip $75 \mathrm{SW}$. The veins appear to fill a fracture set that cuts the phyllite. They consist of coarse, white quartz, calcite, ankerite and dolomite, 1-2\% pyrite, and traces of arsenopyrite, stibnite, and pyrrhotite. Visible gold occurs in these veins, mostly along their margins. A sample of a vein containing visible gold contains $17.8 \mathrm{ppm}$ gold(Kurtak and others, 1999). Several other veins contain $415 \mathrm{ppb}$ to $63.56 \mathrm{ppm}$ gold, 126 to 3,802 ppm arsenic, and 7 to $748 \mathrm{ppm}$ antimony. Samples of phyllitic with minor pyrite in the vicinity of the veins contain 13 to $38 \mathrm{ppb}$ Au. Eden (2000) also identified traces of marcasite, chalcopyrite, hematite, sphalerite, galena, and rutile in the veins. The rocks in the vicinity are upper Devonian phyllite and mica schist (Eden, 2000).

\section{Alteration:}

The wallrock apparently is not altered.

Age of mineralization:

Deposit model:

Low-sulfide Au-quartz vein (Cox and Singer, 1986; model 36a)

Deposit model number (After Cox and Singer, 1986 or Bliss, 1992): $36 \mathrm{a}$

Production Status: None

Site Status: Probably inactive

Workings/exploration:

Surface sampling and geologic mapping. 
Production notes:

Reserves:

Additional comments:

References:

Maddren, 1913; Kurtak and others, 1999; Eden, 2000.

Primary reference: Kurtak and others, 1999

Reporter(s): J.M. Britton (Anchorage)

Last report date: $8 / 9 / 2002$ 


\section{Site name(s): Unnamed (near the head of Colorado Creek)}

Site type: Occurrence

ARDF no.: WI033

Latitude: 67.3613

Quadrangle: WI B-6

Longitude: 152.6539

Location description and accuracy:

This occurrence is about 3 miles east of the junction of Colorado and Mettenpherg Creeks. The occurrence is at an elevation of about 1,160 meters, about 0.3 mile north of the center of section 3, T. 29 N., R. $23 \mathrm{~W}$., of the Fairbanks Meridian. The occurrence is the site of sample 228 in Dillon and others (1981 [AOF 133]). The location is accurate.

\section{Commodities:}

Main: $\mathrm{Ag}, \mathrm{Cu}$

Other: $\mathrm{Bi}, \mathrm{Mn}$

Ore minerals:

\section{Gangue minerals:}

Geologic description:

This occurrence consists of mineralized, calcareous, biotite-quartz-chlorite-albite schist probably derived from intermediate meta-igneous rock (Dillon and others, 1981 [AOF 133B]). A grab sample contains 100 ppm silver, more than 20,000 ppm copper, $100 \mathrm{ppm}$ bismuth, and 5,000 ppm manganese. No sulfides are noted in the sample description. The rocks in the area are Proterozoic(?) banded schist (Dillon and others, 1986). No other information is available.

\section{Alteration:}

Age of mineralization:

Deposit model:

Deposit model number (After Cox and Singer, 1986 or Bliss, 1992):

Production Status: None

Site Status: Inactive

Workings/exploration:

Only surface sampling.

Production notes:

Reserves:

Additional comments:

\section{References:}


Dillon and others, 1981 (AOF 133B); Dillon and others, 1986.

Primary reference: Dillon and others, 1981 (AOF 133B)

Reporter(s): J.M. Britton (Anchorage)

Last report date: $8 / 9 / 2002$ 


\title{
Site name(s): Ann
}

\author{
Site type: Prospect
}

ARDF no.: WI034

Latitude: 67.3954

Quadrangle: WI B-6

Longitude: 152.8472

Location description and accuracy:

The Ann prospect is located 3.5 miles east-northeast of the east end of Ernie Lake and about 3.5 miles northwest of the junction of Pass Creek and Mettenpherg Creek. The coordinates mark the principle mineral showing; it is on an unnamed creek at an elevation of about 580 meters, just east of the center of section 26, T. 30 N., R. 24 W., of the Fairbanks Meridian. There are other mineral showings in the vicinity; most are up to 500 feet upstream and downstream from the main showing. The location is accurate.

\section{Commodities:}

Main: $\mathrm{Ag}, \mathrm{Cu}, \mathrm{Pb}, \mathrm{Zn}$

Other: $\mathrm{Au}$

Ore minerals: Arsenopyrite(?), azurite, chalcopyrite, galena, malachite, pyrite, pyrrhotite(?), sphalerite

Gangue minerals: Barite, quartz

Geologic description:

This occurrence consists of vein and stratabound(?) $\mathrm{Pb}-\mathrm{Zn}$ deposits that consist of massive, stringer, and disseminated sulfides in pelitic schist interbeds in the Devonian, Skajit Limestone, adjacent to the Ernie Lake granitic plutons (Nokleberg and others, 1996). The principal mineral showing at the Ann prospect is a steeply-dipping lens of massive pyrite, sphalerite, galena and minor chalcopyrite between graphitic quartz schist and sericite-talc schist (Kurtak and others, 1999). The lens is 4-5 feet thick and is exposed for only about 6 to 7 feet before pinching out in one direction and disappearing under cover in the other. A chip sample across this lens contains 3.34\% lead, $4.31 \%$ zinc, 2.64 ounces of silver per ton, and 2,478 ppb gold (Kurtak and others, 1999). Bedded quartz-barite rock occurs a few hundred feet from the main $\mathrm{Pb}-\mathrm{Zn}$ showing, but it contains no sulfides.

Several similar, but smaller, deposits are within a few hundred feet of the main showing. One of these deposits consists of pyrite, arsenopyrite, pyrrhotite(?), galena, and chalcopyrite in layers and veins in calcareous, quartz-mica schist near the contact of granite gneiss and marble. A sample contains 37.7 ppm silver, $13 \%$ arsenic, 3.8\% lead, 1.8\% zinc, 315 ppm antimony (Dillon and others, 1981; sample 480 [AOF 133B]). Secondary copper carbonates--malachite and azurite--occur in the marble, calc-schist, and pelitic schist layers.

Claims were staked in 1975 (Grybeck, 1977). Exploration included surface rock sampling, geologic mapping, geochemical soil sampling, hand trenching, and ground geophysics. There was also limited surface rock sampling by government agencies in 1980's and 1990's (Dillon and others, 1981 [AOF 133B]; Kurtak and others, 1999).

Alteration:

Oxidation of copper mineral(s).

Age of mineralization:

Deposit model:

Polymetallic vein (metamorphosed) (Cox and Singer, 1986; model 22c) or Metamorphosed sulfide deposit 
(Nokleberg and others, 1987)

Deposit model number (After Cox and Singer, 1986 or Bliss, 1992):

$22 c(?)$

Production Status: None

Site Status: Inactive

Workings/exploration:

Claims were staked in 1975 (Grybeck, 1977). Exploration included surface rock sampling, geologic mapping, geochemical soil sampling, hand trenching, and ground geophysics. There was also limited surface rock sampling by government agencies in 1980's and 1990's (Dillon and others, 1981 [AOF 133B] Kurtak and others, 1999).

\section{Production notes:}

\section{Reserves:}

\section{Additional comments:}

See also Buzz (WI047).

\section{References:}

Grybeck, 1977; Dillon and others, 1981 (AOF 133B); Arctic Environmental Information and Data Center, 1982; Bundtzen and others, 1984; Eakins and others, 1985; Maas, 1987; Nokleberg and others, 1987; Bliss and others, 1988; Nokleberg and others, 1996; Kurtak and others, 1999; Kurtak and others, 2002.

Primary reference: Kurtak and others, 2002

Reporter(s): J.M. Britton (Anchorage)

Last report date: $8 / 9 / 2002$ 


\section{Site name(s): Colorado Creek}

Site type: Mine

ARDF no.: WI035

Latitude: 67.3801

Quadrangle: WI B-6

Longitude: 152.7202

Location description and accuracy:

Colorado Creek is a west-northwest-flowing tributary of upper Mettenpherg Creek. Their junction is approximately 6.5 miles east of the east end of Ernie Lake. The location of mining on Colorado Creek is unknown. The prospect is arbitrarily located near the mouth of the creek at an elevation of about 480 meters.

\section{Commodities:}

Main: $\mathrm{Au}$

Other:

Ore minerals: Gold

Gangue minerals:

Geologic description:

Reed (1938) reported mining activity on Colorado Creek in 1937. Bliss and others (1988) speculate that gold in Colorado Creek may be derived from unspecified skarns in the headwaters of the Colorado Creek . No other information is available.

Alteration:

Age of mineralization:

Quaternary.

Deposit model:

Placer Au (Cox and Singer, 1986; model 39a)

Deposit model number (After Cox and Singer, 1986 or Bliss, 1992):

$39 \mathrm{a}$

Production Status: Undetermined.

Site Status: Inactive

Workings/exploration:

Small-scale mining by booming and shoveling in from a small cut in 1937 (Reed, 1938).

Production notes:

Reserves:

Additional comments:

\section{References:}


Smith, 1912; Smith, 1913; Smith and Mertie, 1930; Reed, 1938; Cobb, 1972 (MF-469); Cobb, 1976 (OF76340); Bliss and others, 1988; Kurtak and others, 2002.

Primary reference: Reed, 1938

Reporter(s): J.M. Britton (Anchorage)

Last report date: $8 / 9 / 2002$ 


\title{
Site name(s): Unnamed (northwest of Colorado Creek)
}

Site type: Occurrence

ARDF no.: WI036

Latitude: 67.3942

Quadrangle: WI B-6

Longitude: 152.7537

Location description and accuracy:

This occurrence is located about 0.9 mile northwest of the mouth of Colorado Creek and almost 6 miles east of the east end of Ernie Lake. The occurrence is at an elevation of of about 1,120 meters, about 0.4 mile west-southwest of the center of section 29, T. 30 N., R. 23 W., of the Fairbanks Meridian. The occurrence is the site of sample 169 in Dillon and others (1981 [AOF 133B]). The location is accurate.

\section{Commodities:}

Main: Sn

Other:

Ore minerals: Cassiterite

Gangue minerals: Fluorite

Geologic description:

This occurrence consists of cassiterite and fluorite disseminated in pale green to white, fluorite-muscovite, granitic gneiss in the contact zone of a Proterozoic(?) granite gneiss (Dillon and others, 1981 [AOF 133B]; 1986). A sample of cassiterite-bearing gneiss contains $70 \mathrm{ppm}$ tin.

\author{
Alteration: \\ Age of mineralization: \\ Deposit model: \\ Porphyry Sn (?) (Cox and Singer, 1986; model 20a) \\ Deposit model number (After Cox and Singer, 1986 or Bliss, 1992): \\ $20 \mathrm{a}(?)$
}

Production Status: None

Site Status: Inactive

Workings/exploration:

Only surface sampling.

Production notes:

Reserves:

Additional comments:

References: 
Dillon and others, 1981 (AOF 133B); Dillon and others, 1986; Bliss and others, 1988.

Primary reference: Dillon and others, 1981 (AOF 133B)

Reporter(s): J.M. Britton (Anchorage)

Last report date: $8 / 9 / 2002$ 


\section{Site name(s): Unnamed (northwest of Colorado Creek)}

Site type: Occurrence

ARDF no.: WI037

Latitude: 67.3992

Quadrangle: WI B-6

Longitude: 152.7581

Location description and accuracy:

This occurrence is located about 1.2 miles northwest of the mouth of Colorado Creek and about 6 miles east of the east end of Ernie Lake. The occurrence is at an elevation of about 1,160 meters; it is about 0.2 mile south-southwest of the top of hill 1224, about 0.5 mile northwest of the center of section 29 , T. $30 \mathrm{~N}$., R. 23 W., of the Fairbanks Meridian. The occurrence is the site of sample 225 in Dillon and others (1981 [AOF 133B]). The location is accurate.

\section{Commodities:}

Main: $\mathrm{Ag}, \mathrm{Cu}, \mathrm{Zn}$

Other: $\mathrm{Bi}, \mathrm{Sn}$

Ore minerals: Azurite, bornite, malachite, sphalerite

Gangue minerals: Epidote, garnet

Geologic description:

This occurrence consists of azurite- and malachite-stained, garnet-epidote skarn that contains bornite and sphalerite (Dillon and others, 1981; sample 225 [AOF 133B]). A sample of skarn contains 7 ppm silver, 200 ppm bismuth, 5,000 ppm copper, 1,000 ppm tin, and 3,000 ppm zinc. The rocks in the area are Proterozoic(?) granitic rocks in contact with Proterozoic(?) marble, quartzite, and metabasite (Dillon and others, 1986).

Alteration:

Skarn development. Oxidation of copper mineral(s).

Age of mineralization:

Deposit model:

Cu skarn deposit (Cox and Singer, 1986; model 18b)

Deposit model number (After Cox and Singer, 1986 or Bliss, 1992): $18 b$

Production Status: None

Site Status: Inactive

Workings/exploration:

Only surface sampling.

Production notes:

Reserves: 
Additional comments:

References:

Dillon and others, 1981 (AOF 133B); Dillon and others, 1986; Bliss and others, 1988.

Primary reference: Dillon and others, 1981 (AOF 133B)

Reporter(s): J.M. Britton (Anchorage)

Last report date: $8 / 9 / 2002$ 


\section{Site name(s): Unnamed (northwest of Colorado Creek)}

Site type: Occurrence

ARDF no.: WI038

Latitude: 67.4050

Quadrangle: WI B-6

Longitude: 152.7667

Location description and accuracy:

This occurrence is located about 1.7 miles northwest of the junction of Colorado and Mettenpherg Creeks and about 5.8 miles east-northeast of the east end of Ernie Lake. The occurrence is at an elevation of about 1,100 meters, near the southeast corner of section 19, T. 30 N., R. 23 W., of the Fairbanks Meridian. The occurrence is the site of sample 224 in Dillon and others (1981 [AOF 133B]). The location is accurate.

\section{Commodities:}

Main: $\mathrm{Ag}, \mathrm{Cu}, \mathrm{Sn}, \mathrm{Zn}$

Other: $\mathrm{B}, \mathrm{Be}, \mathrm{Bi}, \mathrm{Cd}$

Ore minerals: Azurite, cassiterite, malachite, and unspecified sulfides

Gangue minerals: Calcite, diopside(?), epidote, garnet, tourmaline, tremolite

\section{Geologic description:}

This occurrence consists of cassiterite, secondary copper minerals, and unspecified sulfides at or near the contact between Proterozoic(?) leucogranite and graphic granite, and marble (Dillon and others, 1981, samples 224 and 288 [AOF 133B]). Samples collected by Dillon and others (1981) include azurite- and malachite-stained granitic rock containing unspecified sulfides (sample 224) and skarn with disseminated cassiterite(?) and malachite staining (sample 288). The skarn consists of garnet, epidote, tremolite, and calcite, with scattered tourmaline and diopside(?). A sample of the granitic rock contains up to 20 ppm silver, 5,000 ppm copper, 700 ppm tin, 1,500 ppm zinc, 2,000 ppm boron, 20 ppm beryllium, 200 ppm bismuth, and $100 \mathrm{ppm}$ cadmium. Samples of skarn contain up to $70 \mathrm{ppm}$ bismuth, $150 \mathrm{ppm}$ tin, and 1,500 ppm, zinc. The rocks in the area are mainly Proterozoic(?) granite gneiss and banded schist (Dillon and others, 1981).

\section{Alteration:}

Age of mineralization:

\section{Deposit model:}

Sn skarn deposit (?) (Cox and Singer, 1986; model 14b)

Deposit model number (After Cox and Singer, 1986 or Bliss, 1992): $14 \mathrm{~b}(?)$

Production Status: None

Site Status: Inactive

Workings/exploration:

Only surface sampling.

Production notes: 


\section{Reserves:}

Additional comments:

References:

Dillon and others, 1981 (AOF 133B); Bliss and others, 1988.

Primary reference: Dillon and others, 1981 (AOF 133B)

Reporter(s): J.M. Britton (Anchorage)

Last report date: $8 / 9 / 2002$ 


\section{Site name(s): Unnamed (west of Mettenpherg Creek)}

Site type: Occurrence

ARDF no.: WI039

Latitude: 67.3014

Quadrangle: WI B-6

Longitude: 152.7989

Location description and accuracy:

This occurrence is west of Mettenpherg Creek at the top of hill 1231, in the SE1/4 section 25, T. 29 N., R. $24 \mathrm{~W}$., of the Fairbanks Meridian. The occurrence is the location of sample 236 in Dillon and others (1981 [AOF 133B]). The location is accurate.

\section{Commodities:}

Main: $\mathrm{Cr}, \mathrm{Ni}, \mathrm{Ti}$

Other: $\mathrm{Ba}, \mathrm{Nb}$

Ore minerals: Rutile

Gangue minerals: Fuchsite, siderite

\section{Geologic description:}

This occurrence consists of greenschist and graphitic schist that contain pebble sized lenses of fuchsite (Dillon and others, 1981 [AOF 133B]). A composite sample contains a percent or more Ti, 3,000 ppm barium, 1,000 ppm chromium, $50 \mathrm{ppm}$ niobium, and $700 \mathrm{ppm}$ nickel. Rutile, fuchsite, and siderite probably account for the high $\mathrm{Ti}, \mathrm{Cr}$ and $\mathrm{Ba}$ values. The sample location is near the contact between Proterozoic(?) banded schist and Devonian, Skajit Limestone (Dillon and others, 1986).

\section{Alteration:}

Age of mineralization:

Deposit model:

Deposit model number (After Cox and Singer, 1986 or Bliss, 1992):

Production Status: None

Site Status: Inactive

Workings/exploration:

Only surface sampling.

Production notes:

Reserves:

Additional comments:

References:

Dillon and others, 1981 (AOF 133B); Dillon and others, 1986; Bliss and others, 1988. 
Primary reference: Dillon and others, 1981 (AOF 133B)

Reporter(s): J.M. Britton (Anchorage)

Last report date: $8 / 9 / 2002$ 


\title{
Site name(s): Unnamed (northwest of junction of Pass and Mettenpherg Creeks)
}

Site type: Occurrence

ARDF no.: WI040

Latitude: 67.3976

Quadrangle: WI B-6

Longitude: 152.8145

Location description and accuracy:

This occurrence is about 4.5 miles east-northeast of the east end of Ernie Lake and about 3 miles northwest of the junction of Pass and Mettenpherg Creeks. The occurrence is at the top of hill 1151 in about the center of section 29, T. 30 N., R. 24 W., of the Fairbanks Meridian. The occurrence is the site of sample 414 in Dillon and others (1981 [AOF 133B]). The location is accurate.

Commodities:

Main: Sn

Other: $\mathrm{F}$

Ore minerals: Cassiterite

Gangue minerals: Fluorite

Geologic description:

This occurrence consists of fluorite and cassiterite disseminated in granite-marble migmatite enclosed in fine grained, blastoporphyritic muscovite-granite gneiss (Dillon and others, 1981 [AOF 133B]). A grab sample of the migmatite contained $50 \mathrm{ppm} \mathrm{Sn}$.

\author{
Alteration: \\ Age of mineralization: \\ Deposit model: \\ Sn vein (?) (Cox and Singer, 1986; model 15b) \\ Deposit model number (After Cox and Singer, 1986 or Bliss, 1992): \\ $15 \mathrm{~b}(?)$
}

Production Status: None

Site Status: Inactive

Workings/exploration:

Production notes:

Reserves:

Additional comments:

References: 
Dillon and others, 1981 (AOF 133B); Bliss and others, 1988.

Primary reference: Dillon and others, 1981 (AOF 133B)

Reporter(s): J.M. Britton (Anchorage)

Last report date: $8 / 9 / 2002$ 


\section{Site name(s): Unnamed (south of Mt. Hecht)}

Site type: Occurrence

ARDF no.: WI041

Latitude: 67.4533

Quadrangle: WI B-6

Longitude: 152.8506

Location description and accuracy:

This occurrence is about a mile south of Mt. Hecht. It is at an elevation of about 1,200 meters, 0.1 mile southwest of the center of section 2, T. 30 N., R. 24 W., of the Fairbanks Meridian. The occurrence is the site of sample 289 of Dillon and others (1981 [AOF 133B]). The location is accurate.

\section{Commodities:}

Main: Sn

Other: Be, Y

Ore minerals: Cassiterite

Gangue minerals:

Geologic description:

This occurrence consists of muscovite-granite orthogneiss that contains disseminated cassiterite (Dillon and others, 1981 [AOF 133B]). A grab sample of the orthogneiss contains 7 ppm beryllium, 50 ppm tin, and $100 \mathrm{ppm}$ yttrium. The sample was collected near the contact with Proterozoic(?) banded schist (Dillon and others, 1986). A composite sample across the contact of the orthogneiss and schist, not far from the location of the orthogneiss sample, contains 5 ppm beryllium, $20 \mathrm{ppm}$ tin, and $70 \mathrm{ppm}$ yttrium.

\section{Alteration:}

Age of mineralization:

Deposit model:

Porphyry Sn (?) (Cox and Singer, 1986; model 20a)

Deposit model number (After Cox and Singer, 1986 or Bliss, 1992):

$20 \mathrm{a}(?)$

Production Status: None

Site Status: Inactive

Workings/exploration:

Only surface sampling.

Production notes:

Reserves:

Additional comments: 


\section{References:}

Dillon and others, 1981 (AOF 133B); Dillon and others, 1986; Bliss and others, 1988.

Primary reference: Dillon and others, 1981 (AOF 133B)

Reporter(s): J.M. Britton (Anchorage)

Last report date: $8 / 9 / 2002$ 


\section{Site name(s): Unnamed (northeast of Ernie Lake)}

Site type: Occurrence

ARDF no.: WI042

Latitude: 67.4121

Quadrangle: WI B-6

Longitude: 152.8739

Location description and accuracy:

This occurrence is about 3 miles northeast of Ernie Lake. It is at an elevation of about 1,240 meters, about 0.4 mile east-northeast of the center of section 22, T. 30 N., R. 24 W., of the Fairbanks Meridian. The occurrence is the site of sample 57 of Dillon and others (1981 [AOF 133B]). The location is accurate.

\section{Commodities:}

Main: Zn

Other: $\mathrm{Fe}$

Ore minerals: Magnetite, pyrite, sphalerite

Gangue minerals:

Geologic description:

This occurrence consists of magnetite, sphalerite, and pyrite in dark green tactite at the contact of a granite pluton (Dillon and others, 1981 [AOF 133B]). A grab sample from an outcrop of the tactite contains 500 ppm zinc and more than $20 \%$ iron. The rocks in the area are mainly Proterozoic(?) granitic rocks, but there is none at this occurrence.

Alteration:

Age of mineralization:

Deposit model:

Fe skarn (?) (Cox and Singer, 1986; model 18d)

Deposit model number (After Cox and Singer, 1986 or Bliss, 1992): $18 \mathrm{~d}(?)$

Production Status: None

Site Status: Inactive

Workings/exploration:

Only surface sampling.

Production notes:

Reserves:

Additional comments:

References: 
Dillon and others, 1981 (AOF 133B); Dillon and others, 1986; Bliss and others, 1988.

Primary reference: Dillon and others, 1981 (AOF 133B)

Reporter(s): J.M. Britton (Anchorage)

Last report date: $8 / 9 / 2002$ 


\section{Site name(s): Unnamed (east of Ernie Lake)}

Site type: Occurrence

ARDF no.: WI043

Latitude: 67.3949

Quadrangle: WI B-6

Longitude: 152.8897

Location description and accuracy:

This occurrence is located about 2.2 miles east-northeast of the east end of Ernie Lake. The occurrence is at an elevation of about 1,240 meters, about 0.1 mile southwest of the center of section 27, T. 30 N., R. 24 W., of the Fairbanks Meridian. The occurrence is the site of sample 172 in Dillon and others (1981 [AOF 133B]). The location is accurate.

\section{Commodities:}

Main: Sn

Other: F

Ore minerals: Cassiterite

Gangue minerals: Fluorite

Geologic description:

This occurrence consists of fluorite and cassiterite disseminated in border and contact phases of metagranite (Dillon and others, 1981; samples 172 and 455 [AOF 133B]). The contact rocks are light-olive-green, schistose, chlorite-muscovite granite gneiss. The border phase is blastoporphyritic, muscovite-biotite granite orthogneiss. Samples of both phases contain disseminated fluorite and cassiterite. Samples of schistose metagranite contain $20 \mathrm{ppm}$ Sn. No other anomalous metals were found.

\section{Alteration:}

Age of mineralization:

\section{Deposit model:}

Porphyry Sn (?) (Cox and Singer, 1986; model 20a)

Deposit model number (After Cox and Singer, 1986 or Bliss, 1992): $20 \mathrm{a}(?)$

Production Status: None

Site Status: Inactive

Workings/exploration:

Only surface sampling.

Production notes:

Reserves: 
Additional comments:

\section{References:}

Dillon and others, 1981 (AOF 133B); Bliss and others, 1988.

Primary reference: Dillon and others, 1981 (AOF 133B)

Reporter(s): J.M. Britton (Anchorage)

Last report date: $8 / 9 / 2002$ 


\section{Site name(s): Frog}

Site type: Prospect

ARDF no.: WI044

Latitude: 67.3178

Quadrangle: WI B-6

Longitude: 152.9171

Location description and accuracy:

The Frog prospect is located about 5 miles south-southeast of the west end of Ernie Lake, and about 5 miles west of upper Mettenpherg Creek. The prospect is at an elevation of about 1,160 meters, just northeast of the top of hill 1222 in the NE1/4 section 28, T. 29 N., R. 24 W., of the Fairbanks Meridian. The prospect is the site of samples 218, 219, and 220 in Dillon and others (1981 [AOF 133B]). There are several smaller occurrences about a mile to the southeast and west. The location is accurate.

\section{Commodities:}

Main: $\mathrm{Ag}, \mathrm{Pb}, \mathrm{Zn}$

Other: $\mathrm{Cu}$

Ore minerals: Arsenopyrite(?), chalcocite, chalcopyrite, galena, hydrozincite, pyrite, sphalerite

\section{Gangue minerals:}

\section{Geologic description:}

The Frog prospect consists of stratiform sphalerite, galena and pyrite in Devonian, Skajit Limestone, and pyrite and minor base metals in siliceous schists within and underlying the carbonate rocks (Kurtak and others, 2002). The principal mineralization consists of disseminated to semi-massive sphalerite-galena-pyrite layers, typically in gray to white, thin-bedded, calcarenite, but also in micaceous interbeds. Individual layers are lensoidal, and only continue 10 feet or less along strike. The lenses average 2 to 3 inches thick, although some are as much as a foot thick. Light brown sphalerite is typically the most abundant sulfide mineral. Although the sulfide layers are distributed sporadically through several hundred feet of the sedimentary section, the main mineralized horizon is a 10- to 35-foot-thick zone in which there is a concentration of sulfide layers. This horizon can be traced for about 350 to 400 feet along strike. Selected samples contain up to $30 \%$ zinc, $7 \%$ lead, and 1 ounces of silver per ton. But samples across widths of 5 feet or more typically contain less than 2 or 3\% zinc and lead; these values do not persist along strike. Dillon and others (1981 [AOF 133B]) collected three samples in the main ore horizon of quartzite, schist, and conglomerate with arsenopyrite(?), pyrite, sphalerite, and galena; the samples contain up to $100 \mathrm{ppm}$ silver, $1 \%$ lead, $4 \%$ zinc, and $10 \mathrm{ppm}$ antimony. Narrow, 0.2 - to 2 -inch veins of sphalerite and galena may result from remobilization of the stratiform sulfides into cleavages and fractures.

Scattered occurrences of massive to disseminated pyrite and minor sphalerite and galena that are stratigraphically below the main ore horizon extend for up to a mile west. These are 3- to 12-inch-thick, discontinuous stratiform layers in calcareous quartz-muscovite schist. The layers are near the contact of the overlying Skajit Limestone.

Approximately 0.8 to 1 mile southeast of the main mineral showing, scattered clots of chalcopyrite and disseminated pyrite and chalcopyrite occur along bedding planes in gray to white, thin-bedded, massive to laminated quartzite. This siliceous unit is 10 to 15 feet thick and is a member of the Skajit Limestone that is stratigraphically above the principal mineralized horizon. This area also contains a small, isolated, chalcocite-bearing quartz segregations in chlorite schist.

Ninety-eight mining claims were located from 1976 to 1978; subsequent exploration includes geologic mapping, surface rock and soil sampling, geophysical surveys, and 7 diamond drill holes (Kurtak and others, 2002). 


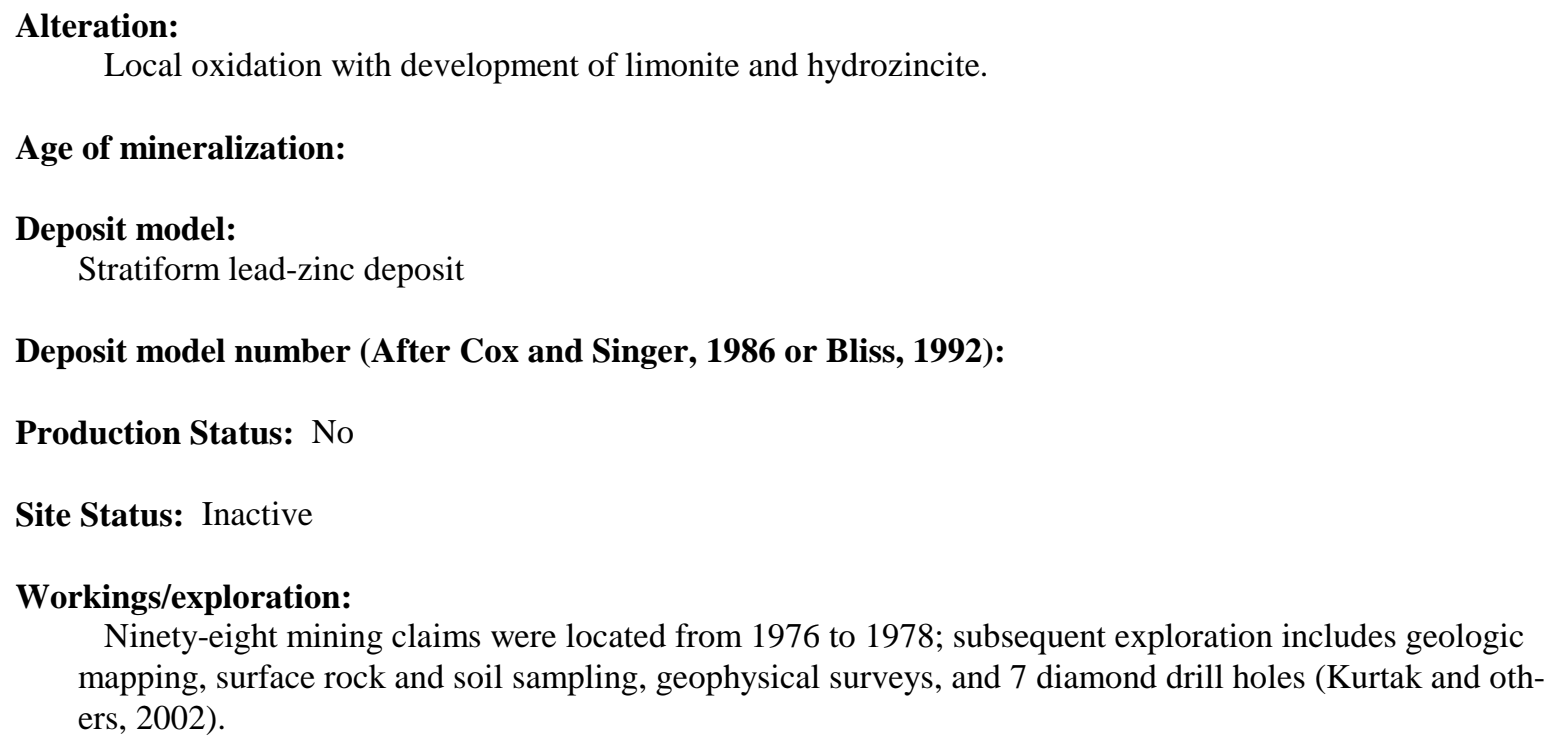

Production notes:

Reserves:

Additional comments:

\section{References:}

Dillon and others, 1981 (AOF 133B); Maas, 1987; Bliss and others, 1988; Kurtak and others, 2002.

Primary reference: Kurtak and others, 2002

Reporter(s): J.M. Britton (Anchorage)

Last report date: $8 / 9 / 2002$ 


\section{Site name(s): Unnamed (south of Ernie Lake)}

Site type: Occurrence

ARDF no.: WI045

Latitude: 67.3565

Quadrangle: WI B-6

Longitude: 152.9686

Location description and accuracy:

This occurrence is located about 2.2 miles south of the east end of Ernie Lake. The occurrence is at the top of a ridge at an elevation of about 1,320 meters, about 0.4 mile west of the top of hill 1425 , in the NW1/4 section 8, T. 29 N., R. 25 W of the Fairbanks Meridian. This occurrence is the site of sample 54 in Dillon and others (1981 [AOF 133B]). The location is accurate.

\section{Commodities:}

Main: $\mathrm{Pb}$

Other:

Ore minerals: Galena(?), pyrite

\section{Gangue minerals:}

Geologic description:

This occurrence consists of chlorite-talc-quartz schist with lenses of pyrite and galena(?) less than $6 \mathrm{~cm}$ long (Dillon and others, 1981 [AOF 133B]). The rocks in the area consist of Devonian, Skajit Limestone and/or Proterozoic(?) banded schist (Dillon and others, 1986).

\section{Alteration:}

Age of mineralization:

Deposit model:

Deposit model number (After Cox and Singer, 1986 or Bliss, 1992):

Production Status: None

Site Status: Inactive

Workings/exploration:

Only surface sampling.

Production notes:

Reserves:

Additional comments:

This occurrence is in Gates of the Arctic National Park.

References:

Dillon and others, 1981 (AOF 133B); Dillon and others, 1986; Bliss and others, 1988. 
Primary reference: Dillon and others, 1981 (AOF 133B)

Reporter(s): J.M. Britton (Anchorage)

Last report date: $8 / 9 / 2002$ 


\section{Site name(s): Unnamed (near Mettenpherg Creek)}

Site type: Occurrence

ARDF no.: WI046

Latitude: 67.2902

Quadrangle: WI B-6

Longitude: 152.8755

Location description and accuracy:

This occurrence is approximately 4 miles west of upper Mettenpherg Creek, at an elevation of about 1,120 meters, in the SE /4 SE1/4 section 34, T. 29 N., R. 24 W., of the Fairbanks Meridian. The location is accurate within one-half mile.

\section{Commodities:}

Main: $\mathrm{Pb}, \mathrm{Zn}$

Other: $\mathrm{Cu}$

Ore minerals: Chalcopyrite, galena, magnetite, malachite, pyrite, sphalerite

Gangue minerals:

\section{Geologic description:}

This occurrence consists of stratabound(?), disseminated to massive magnetite and pyrite, with minor galena, in sericitic dolomite (Kurtak and others, 2002). The mineralization occurs in bands up to 4 feet thick that can be traced for 100 to 150 feet along strike. The occurrence also includes malachite-stained, dolomite breccia that contains minor chalcopyrite. Mineralized float with pyrite, galena, and sphalerite occurs in streams that drain this occurrence. The rocks in the area are principally gray marble, interbedded with dolomite, quartzite, and greenstone (Kurtak and others, 2002).

\section{Alteration:}

Local oxidation of copper mineral.

Age of mineralization:

\section{Deposit model:}

Deposit model number (After Cox and Singer, 1986 or Bliss, 1992):

\section{Production Status:}

Site Status: Inactive

\section{Workings/exploration:}

Surface mapping and sampling.

Production notes:

Reserves:

Additional comments: 


\section{References:}

Kurtak and others, 2002.

Primary reference: Kurtak and others, 2002

Reporter(s): J.M. Britton (Anchorage)

Last report date: $8 / 9 / 2002$ 


\section{Site name(s): Buzz; Buzzard}

Site type: Prospect

ARDF no.: WI047

Latitude: 67.4150

Quadrangle: WI B-6

Longitude: 152.8575

Location description and accuracy:

The Buzz prospect is about 3.5 miles northeast of the east end of Ernie Lake and 4.5 miles northwest of the junction of Pass Creek and Mettenpherg Creek. The prospect is at an elevation of about 1,300 meters, about 0.3 mile northwest of the center of section 23, T. 30 N., R. 24 W., of the Fairbanks Meridian. This location is the principal mineral showing among several in the vicinity. The location is accurate.

\section{Commodities:}

Main: $\mathrm{Ag}, \mathrm{Pb}, \mathrm{Zn}$

Other: $\mathrm{As}, \mathrm{Au}, \mathrm{Cd}, \mathrm{Sb}$

Ore minerals: Arsenopyrite, galena, malachite, pyrite, sphalerite

\section{Gangue minerals:}

\section{Geologic description:}

The Buzz prospect consists of massive $\mathrm{Zn}-\mathrm{Pb}$ sulfide mineralization in rocks of the upper section of the Devonian, Skajit Limestone (Kurtak and others, 2002). The mineralization consists of small exposures of massive pyrite, sphalerite, galena and minor arsenopyrite in marble and in schist interbeds in the marble. Locally, the rocks are coated with malachite. Pyrite is the most abundant sulfide mineral. There are two principal mineralized outcrops, separated by more than 100 feet of barren rubble; the mineralization does not appear to be continuous between them, although scattered gossan and sulfide float occur for a considerable distance from the outcrops. The maximum dimensions of the mineralized exposures are 10 feet or less. Chip samples collected from the two principal mineralized outcrops contain 3.9 to $7.23 \%$ lead, 4.7 to $22.7 \%$ zinc, 2.2 to 5.7 ounces of silver per ton, 2,337 to 2,435 ppb gold, 6,480 to more than 10,000 ppm arsenic, 531 to more than 2,000 ppm antimony, and 1,451 to 1,509 ppm Cu (Kurtak and others, 1999).

The Skajit Limestone in this area is gray marble that contains irregular interbeds of dolomite, quartzite, quartz-muscovite schist, and chlorite schist (Kurtak and others, 2002). A small remnant of Hunt Fork Shale crops out west of the area of the mineralized outcrops and granitic rocks occur to the east. The mineralization appears to be spatially related to shear zones and not to the nearby granitic intrusions (Kurtak and others, 2002).

At least one company staked claims and conducted exploration in the 1970's (Kurtak and others, 2002). Exploration included surface rock sampling, geologic mapping, geochemical soil sampling, hand trenching, and ground geophysics. The Bureau of Land Management carried out limited surface rock sampling in the 1990's (Kurtak and others, 1999).

\section{Alteration:}

Oxidation of iron and copper minerals.

\section{Age of mineralization:}

Deposit model:

Polymetallic vein (metamorphosed) (Cox and Singer, 1986; model 22c) or Metamorphosed sulfide deposit (Nokleberg and others, 1987) 
Deposit model number (After Cox and Singer, 1986 or Bliss, 1992):

$22 \mathrm{c}(?)$

Production Status: None

Site Status: Inactive

Workings/exploration:

At least one company staked claims and conducted exploration in the 1970's (Kurtak and others, 2002). Exploration included surface rock sampling, geologic mapping, geochemical soil sampling, hand trenching, and ground geophysics. The Bureau of Land Management carried out limited surface rock sampling in the 1990's (Kurtak and others, 1999).

Production notes:

Reserves:

Additional comments:

See also Ann (WI034).

\section{References:}

Maas, 1987; Kurtak and others, 1999; Kurtak and others, 2002.

Primary reference: Kurtak and others, 2002

Reporter(s): J.M. Britton (Anchorage)

Last report date: $8 / 9 / 2002$ 


\section{Site name(s): Abo}

Site type: Prospects

ARDF no.: WI048

Latitude: 67.4504

Quadrangle: WI B-6

Longitude: 152.7180

Location description and accuracy:

The Abo prospect is about 3.8 miles east-southeast of Mount Hecht. Mineralization has been found at three locations on the property. The coordinates reflect the more-or-less centrally-located showing. It is at an elevation of about 1,240 meters, about 0.4 mile southwest of the center of section 4, T. 30 N., R. 23 W., of the Fairbanks Meridian. The other two locations are approximately 3,000 feet northwest and southeast of the central prospect. The location is accurate.

\section{Commodities:}

Main: $\mathrm{Ag}, \mathrm{Pb}, \mathrm{Zn}$

Other:

Ore minerals: Galena, pyrite, sphalerite

\section{Gangue minerals:}

\section{Geologic description:}

The Abo prospect consists of zinc and lead mineralization in the upper portion of the Devonian, Skajit Limestone (Kurtak and others, 2002). The mineralization is generally near the contact between sandy, micaceous limestone, which constitutes the uppermost part of the Skajit Limestone in this area, and underlying massive, gray marble. The Skajit Limestone contains lenses or interbeds of dolomite, sandstone, quartzite, quartz-mica schist, and chlorite schist. The dolomitic rocks occur as irregular zones and as individual dolomite units within the gray marble. The Skajit Limestone is overlain by Upper Devonian, Hunt Fork Shale.

There are three principal mineral showings (Kurtak and others, 2002). In two of the areas, stratabound sphalerite and galena occur in thin bands along the contact between sandy limestone and massive marble, and in a quartzose, dolomitic interbed in the marble. Individual bands of sulfide mineralization range in thickness from less than 1 inch to 2.5 feet. The extent of the mineralization along strike appears to be limited (in part due to overburden); the maximum traceable length is 175 feet. Selected samples of this mineralization contain up to $25 \%$ zinc and lead, and 2.4 ounces of silver per ton. More systematic sampling indicates the grades are generally less than $1 \%$ lead and $5 \%$ zinc over widths of a few tens of feet or less (Kurtak and others, 2002).

Sphalerite, galena, and minor pyrite, form disseminations, stringers, and pod-like bodies in siliceous and/ or dolomitic zones in one of the two areas described above, as well as in the third area. This mineralization, where it is stratabound, appears to be stratigraphically below the mineralization along the contact between the limestone and gray marble. The siliceous, mineralized bodies typically are 5 to 20 feet in length, and one is 150 feet long. Chip samples of this mineralization contain up to $13.5 \%$ combined zinc and lead, and 0.35 ounce of silver per ton. Two drill intercepts give values of $9.47 \%$ zinc, $0.96 \%$ lead, and 0.17 ounce of silver per ton over 15.5 feet; , and $0.44 \%$ zinc, $1.55 \%$ lead, and 0.14 ounce of silver per ton over 6 feet (Kurtak and others, 2002). A float sample contains $22.41 \%$ zinc, $1.8 \%$ lead, 0.34 ounce of silver per ton, and 77 ppb gold (Kurtak and others, 1999). A continuous chip sample of siliceous rock with abundant sphalerite contains $12.92 \%$ zinc, $0.34 \%$ lead, 2.7 ounces of silver per ton, and $19 \mathrm{ppb}$ gold.

Mining claims were staked in the mid-1970's (Grybeck, 1977). Extensive exploration has included geologic mapping, geochemical sampling, geophysics surveys, and diamond drilling (Kurtak and others, 2002). 
Alteration:

Age of mineralization:

Deposit model:

Polymetallic replacement deposit (?) (Cox and Singer, 1986; model 19a)

Deposit model number (After Cox and Singer, 1986 or Bliss, 1992):

$19 \mathrm{a}(?)$

Production Status:

Site Status:

Workings/exploration:

Mining claims were staked in the mid-1970's (Grybeck, 1977). Extensive exploration has included geologic mapping, geochemical sampling, geophysics surveys, and diamond drilling (Kurtak and others, 2002).

Production notes:

Reserves:

Additional comments:

References:

Grybeck, 1977; Arctic Environmental Information and Data Center, 1982; Maas, 1987; Kurtak and others, 1999; Kurtak and others, 2002.

Primary reference: Kurtak and others, 2002

Reporter(s): J.M. Britton (Anchorage)

Last report date: $8 / 9 / 2002$ 


\section{Site name(s): Zinc}

Site type: Occurrence

ARDF no.: WI049

Latitude: 67.3990

Quadrangle: WI B-6

Longitude: 152.6931

Location description and accuracy:

This occurrence is 3.25 miles north-northeast of the junction of Pass and Mettenpherg Creeks. The occurrence is at an elevation of about 780 meters, about 0.3 mile northeast of the center of section $28, \mathrm{~T}$. $30 \mathrm{~N}$., R. 23 W., of the Fairbanks Meridian. The location is accurate within 1 mile.

\section{Commodities:}

Main: $\mathrm{Pb}, \mathrm{Zn}$

Other:

Ore minerals: Galena, sphalerite

Gangue minerals:

Geologic description:

This occurrence consists of sphalerite and galena in carbonate rocks (Grybeck, 1977, no. 5). The rocks in the area are Devonian, Skajit Limestone (Dillon and others, 1986). No other information is available for this occurrence.

Alteration:

Age of mineralization:

Deposit model:

Polymetallic replacement deposit (?) (Cox and Singer, 1986; model 19a)

Deposit model number (After Cox and Singer, 1986 or Bliss, 1992): $19 \mathrm{a}(?)$

Production Status: None

Site Status: Inactive

Workings/exploration:

Eight mining claims were located in 1975 (Grybeck, 1977).

Production notes:

Reserves:

Additional comments:

References:

Grybeck, 1977; Maas, 1987. 
Primary reference: Grybeck, 1977, Maas, 1987

Reporter(s): J.M. Britton (Anchorage)

Last report date: 8/9/2002 


\section{Site name(s): Tana}

Site type: Prospect

ARDF no.: WI050

Latitude: 67.3308

Quadrangle: WI B-6

Longitude: 152.5135

Location description and accuracy:

This prospect is at an elevation of about 1,000 meters, just above the center of the southern boundary of section 17, T. 29 N., R. 23 W., of the Fairbanks Meridian. The location is accurate.

Commodities:

Main: $\mathrm{Ag}, \mathrm{Pb}, \mathrm{Zn}$

Other: $\mathrm{Cu}$

Ore minerals: Chalcopyrite, galena, pyrite, sphalerite

Gangue minerals:

\section{Geologic description:}

This prospect consists of oxidized, sulfide-bearing blocks of talus (Kurtak and others, 2002). The talus is distributed along two northwest-trending linear zones that are roughly parallel to the strike of underlying Devonian, Skajit Limestone. The sulfides occur in the matrix of dolomite breccia, and consist predominately of sphalerite with smaller amounts of galena and pyrite, and traces of chalcopyrite. A composite sample of the talus contains $4.4 \%$ lead, $6.7 \%$ zinc , and 4.03 ounces of silver per ton. (Kurtak and others, 2002).

\section{Alteration:}

The sulfides are oxidized to limonitic gossan.

Age of mineralization:

Deposit model:

Polymetallic replacement deposit (?) (Cox and Singer, 1986; model 19a)

Deposit model number (After Cox and Singer, 1986 or Bliss, 1992):

$19 \mathrm{a}(?)$

Production Status: None

Site Status: Inactive

Workings/exploration:

Kurtak and others (2002) report that mining claims were located in 1977 and surface mapping, trenching, and soil sampling were done in 1978.

Production notes:

Reserves:

Additional comments: 
See also: Frog (WI044).

\section{References:}

Kurtak and others, 2002.

Primary reference: Kurtak and others, 2002

Reporter(s): J.M. Britton (Anchorage)

Last report date: 8/9/2002 


\section{Site name(s): Unnamed (northeast of Ernie Lake)}

Site type: Occurrence

ARDF no.: WI051

Latitude: 67.4239

Quadrangle: WI B-6

Longitude: 152.8585

Location description and accuracy:

This occurrence is located about 4 miles northeast of Ernie Lake. The occurrence is at an elevation of about 1,700 meters, about 0.2 mile west-southwest of the center of section 14, T. 30 N., R. 24 W., of the Fairbanks Meridian. The occurrence is the site of sample 55 of Dillon and others (1981 [AOF 133B]). The location is accurate.

\section{Commodities:}

Main: Zn

Other: $\mathrm{Pb}(?)$

Ore minerals: Galena(?), pyrite, sphalerite

\section{Gangue minerals:}

Geologic description:

This occurrence consists of maroon, felsic schist that contains 5\% oxidized sulfides (Dillon and others, 1981 [AOF 133B]). The sulfides are principally pyrite and sphalerite, and possibly galena. A rock sample contains $350 \mathrm{ppm} \mathrm{Zn}$. The rocks in the area are Devonian, Skajit Limestone, a few miles south of the Earnie Lake pluton (Dillon and others, 1986). No other information is available.

\section{Alteration:}

Oxidation of sulfide minerals.

Age of mineralization:

Deposit model:

Polymetallic replacement deposit (?) (Cox and Singer, 1986; model 19a)

Deposit model number (After Cox and Singer, 1986 or Bliss, 1992):

$19 \mathrm{a}(?)$

Production Status: None

Site Status: Inactive

Workings/exploration:

Only surface sampling.

Production notes:

Reserves:

Additional comments: 
See also: Buzz (WI047); Ann (WI034).

\section{References:}

Dillon and others, 1981 (AOF 133B); Dillon and others, 1986; Bliss and others, 1988.

Primary reference: Dillon and others, 1981 (AOF 133B)

Reporter(s): J.M. Britton (Anchorage)

Last report date: 8/9/2002 


\section{Site name(s): Unnamed (east of upper Midas Creek)}

Site type: Occurrence

ARDF no.: WI052

Latitude: 67.2597

Quadrangle: WI B-5

Longitude: 152.2327

Location description and accuracy:

This occurrence is located about 6 miles south of the junction of Midas and Sixtymile Creeks. It is at an elevation of about 3,400 feet, 0.1 mile southeast of the top of hill 3567, in section 8, T. 28 N., R. 21 W., of the Fairbanks Meridian. The occurrence is the site of sample 82 in Dillon and others (1981 [AOF 133B]). The location is accurate.

\section{Commodities:}

Main: Zn

Other: As, B, Bi, Sn, W

Ore minerals:

\section{Gangue minerals:}

Geologic description:

This occurrence consists of skarn mineralization in calcareous schist near an intrusive (Dillon and others, 1981 [AOF 133B]). A chip sample of the mineralized rock contains $3000 \mathrm{ppm}$ zinc, more than $50 \mathrm{ppm}$ tungsten, 700 ppm tungsten, 7-- ppm tin, 500 ppm arsenic, 50 ppm bismuth, 700 ppm boron, and $20 \%$ iron. The rocks in the vicinity are Devonian chloritic and carbonate rocks and Devonian, Ambler metavolcanics and metabasite (Dillon and others, 1986).

\section{Alteration:}

Age of mineralization:

Deposit model:

Sn skarn deposit (?) (Cox and Singer, 1986; model 14b)

Deposit model number (After Cox and Singer, 1986 or Bliss, 1992):

$14 \mathrm{~b}(?)$

Production Status: None

Site Status: Inactive

Workings/exploration:

Only surface sampling.

Production notes:

Reserves:

Additional comments: 


\section{References:}

Dillon and others, 1981 (AOF 133B); Dillon and others, 1986; Bliss and others, 1988.

Primary reference: Dillon and others, 1981 (AOF 133B)

Reporter(s): J.M. Britton (Anchorage)

Last report date: $8 / 9 / 2002$ 


\section{Site name(s): Unnamed (south of Organ and Sixtymile Creeks)}

Site type: Occurrence

ARDF no.: WI053

Latitude: 67.3513

Quadrangle: WI B-5

Longitude: 152.4514

Location description and accuracy:

This occurrence is at an elevation of about 3,400 feet, about 0.2 mile southwest of the top of hill 3730, in section 10, T. 29 N., R. 22 W., of the Fairbanks Meridian. The occurrence is the site of sample 280 in Dillon and others (1981 [AOF 133B]). The location is accurate.

\section{Commodities:}

Main: $\mathrm{Cu}, \mathrm{Zn}$

Other:

Ore minerals: Chalcopyrite

Gangue minerals:

Geologic description:

This occurrence consists of albite-chlorite-muscovite-quartz schist that contains minor chalcopyrite (Dillon and others, 1981 [AOF 133B]). The rocks in the vicinity are predominately Devonian, Skajit Limestone, cut by several north-south trending faults (Dillon and others, 1986). A sample of schist contains $1,100 \mathrm{ppm}$ zinc but no copper.

\section{Alteration:}

Age of mineralization:

Deposit model:

Deposit model number (After Cox and Singer, 1986 or Bliss, 1992):

Production Status: None

Site Status: Inactive

Workings/exploration:

Only surface sampling.

Production notes:

Reserves:

Additional comments:

References:

Dillon and others, 1981 (AOF 133B); Dillon and others, 1986; Bliss and others, 1988. 
Primary reference: Dillon and others, 1981(AOF 133B)

Reporter(s): J.M. Britton (Anchorage)

Last report date: $8 / 9 / 2002$ 


\section{Site name(s): Unnamed (west of upper Malamute Fork John River)}

Site type: Occurrence

ARDF no.: WI054

Latitude: 67.2773

Quadrangle: WI B-5

Longitude: 152.4743

Location description and accuracy:

This occurrence is at the top of hill 3836, in section 6, T. 28 N., R. 22 W., of the Fairbanks Meridian. The site corresponds to the location of sample no. 80 in Dillon and others (1981 [AOF 133B]). The location is accurate.

\section{Commodities:}

Main: $\mathrm{Cu}, \mathrm{Pb}$

Other: $\mathrm{Sb}, \mathrm{Zn}$

Ore minerals: Azurite, bornite(?), galena, malachite

Gangue minerals: Quartz

Geologic description:

This occurrence consists of a mineralized stockworks of quartz veins in dolomite (Dillon and others, 1981 [AOF 133B]). The rocks in the area are Devonian, Skajit Limestone, with subordinate metabasite (Dillon and others, 1986). The veins contain malachite, azurite, bornite(?), and galena. A sample of quartz near a contact with greenschist with 5\% magnetite, contains up to 1,500 ppm copper, 1,000 ppm antimony, 240 ppm zinc, and no detectable lead.

Alteration:

Oxidation of copper mineral(s).

Age of mineralization:

Deposit model:

Polymetallic vein(?) (Cox and Singer, 1986; model 22c)

Deposit model number (After Cox and Singer, 1986 or Bliss, 1992): $22 \mathrm{c}(?)$

Production Status: None

Site Status: Inactive

Workings/exploration:

Only surface sampling.

Production notes:

Reserves:

Additional comments: 


\section{References:}

Dillon and others, 1981 (AOF 133B); Dillon and others, 1986; Bliss and others, 1988.

Primary reference: Dillon and others, 1981 (AOF 133B)

Reporter(s): J.M. Britton (Anchorage)

Last report date: $8 / 9 / 2002$ 


\section{Site name(s): Sixtymile Creek; Fool Creek; Sixtymile}

Site type: Prospects

ARDF no.: WI055

Latitude: 67.3490

Quadrangle: WI B-5

Longitude: 152.1644

Location description and accuracy:

Sixtymile Creek is a large, west-flowing tributary to John River. Fool Creek is not named on the Wiseman B-5 topographic map. But according to Maddren (1913), Fool Creek starts at the junction of Sixtymile and Midas Creeks (although Maddren's map labels the Sixtymile Creek as the Fiftymile Creek ), and enters the John River at the mouth of Crevice Creek. The locations of the placer prospects along 'Fool Creek' are unknown. These prospects are arbitrarily located on Sixtymile (Fool) Creek about 0.9 mile west of the mouth of Rock Creek.

\section{Commodities:}

Main: $\mathrm{Au}$

Other:

Ore minerals: Gold

\section{Gangue minerals:}

\section{Geologic description:}

Maddren (1913) reported good prospects on 'Fool Creek' and its tributaries, and Wimmler (1922) reported coarse gold along benches of Sixtymile Creek. (which is probably another name for Fool Creek). According to Kurtak and others (2002), 83 ounces of gold have been recovered from Sixtymile Creek. The rocks in the area consist mostly of Devonian, Skajit Limestone, with subordinate Middle or Upper Devonian(?) chloritic and carbonate rocks and Proterozoic(?) granite gneiss (Dillon and others, 1986).

\section{Alteration:}

Age of mineralization:

Quaternary.

Deposit model:

Placer Au (Cox and Singer, 1986; model 39a)

Deposit model number (After Cox and Singer, 1986 or Bliss, 1992):

$39 \mathrm{a}$

Production Status: Yes

Site Status: Inactive

Workings/exploration:

Some prospecting and mining.

Production notes:

Kurtak and others (2002) report that 83 ounces of gold of gold reported to have been recovered from Six- 
tymile Creek.

\section{Reserves:}

Additional comments:

See also Midas Creek (WI057).

\section{References:}

Schrader, 1904; Brooks, 1905; Maddren, 1910; Maddren, 1913; Smith, 1913; Wimmler, 1922; Wimmler, 1925; Brooks and Capps, 1924; Smith and Mertie, 1930; Smith, 1933 (B836); Smith, 1933 (B844A); Heiner and Wolff, 1968; Cobb, 1976 (OF76-340); Cobb, 1981 (OF81-732); Dillon and others, 1986; Maas, 1987; Kurtak and others, 2002.

Primary reference: Maddren, 1913

Reporter(s): J.M. Britton (Anchorage)

Last report date: $8 / 9 / 2002$ 


\section{Site name(s): McKinley Creek}

Site type: Prospect

ARDF no.: WI056

Latitude: 67.4404

Quadrangle: WI B-5

Longitude: 152.2088

Location description and accuracy:

McKinley Creek is a long, southeast-flowing tributary to the John River. The mouth of McKinley Creek is about 2 miles north of the junction of the Allen and John Rivers. The location and extent of placer prospects on McKinley Creek are unknown; the site is arbitrarily located at an elevation of about 1,500 feet on McKinley Creek, i.e. about in the center of this long creek.

\section{Commodities:}

Main: $\mathrm{Au}$

Other:

Ore minerals: Gold, magnetite, pyrite

\section{Gangue minerals:}

\section{Geologic description:}

Schrader (1900) reported a paystreak of considerable width on McKinley Creek. Cobb (1976 [OF76340]) in summarizing Schrader's report on the McKinley Creek occurrence, indicated that Schrader's location was uncertain and that it might instead be a description of Midas Creek or Crevice Creek. Cobb, however, provides no evidence to support his suggestion. Kurtak and others (1999) collected 3 pannedconcentrate samples from McKinley Creek in the vicinity of this site. One of these samples contained 2 particles of coarse gold, with abundant magnetite and pyrite. The concentrate contains 625 ppb gold. The other 2 samples contained only moderate to minor amounts of magnetite and sulfides. Kurtak and others (1999) did not find any evidence of mining on McKinley Creek.

\section{Alteration:}

\section{Age of mineralization:}

Quaternary.

\section{Deposit model:}

Placer Au (Cox and Singer, 1986; model 39a)

Deposit model number (After Cox and Singer, 1986 or Bliss, 1992): $39 \mathrm{a}$

Production Status: None

Site Status: Inactive

Workings/exploration:

Schrader (1900) noted that 50 men were mining in the area in 1900. This, however, may have referred to creeks other than McKinley Creek, as Kurtak and others (1999) found no evidence of mining. 
Production notes:

Questionable prospecting and mining.

Reserves:

Additional comments:

References:

Schrader, 1900; Heiner and Wolff, 1968; Cobb, 1976 (OF76-340); Maas, 1987; Kurtak and others, 1999.

Primary reference: Kurtak and others, 1999

Reporter(s): J.M. Britton (Anchorage)

Last report date: $8 / 9 / 2002$ 


\section{Site name(s): Midas Creek}

Site type: Occurrence

ARDF no.: WI057

Latitude: 67.3047

Quadrangle: WI B-5

Longitude: 152.2285

Location description and accuracy:

Midas Creek is a long, north-flowing tributary to Sixtymile Creek. The location of placer gold prospects on Midas Creek is unknown. The site is arbitrarily plotted near the cabin shown on the Wiseman B-5 topographic map, about 3 miles upstream of the mouth of the creek. This site approximates the location in Cobb (1972 [MF 469]).

\section{Commodities:}

Main: $\mathrm{Au}$

Other:

Ore minerals: Gold

\section{Gangue minerals:}

Geologic description:

Maddren (1913) reported that good placer gold prospects had been found on Midas Creek in 1905, although these had not been developed by 1913. A small one-man bulldozer-hydraulic mining operation was underway in 1952. No other information is available.

\section{Alteration:}

Age of mineralization:

Quaternary.

Deposit model:

Placer Au (Cox and Singer, 1986; model 39a)

Deposit model number (After Cox and Singer, 1986 or Bliss, 1992):

$39 \mathrm{a}$

Production Status: None

Site Status: Inactive

Workings/exploration:

Maddren (1913) reported that good placer gold prospects had been found on Midas Creek in 1905, although these had not been developed by 1913. A small one-man bulldozer-hydraulic mining operation was underway in 1952.

Production notes:

Reserves: 
Additional comments:

\section{References:}

Schrader, 1904; Brooks, 1905; Maddren, 1910; Maddren, 1913; Smith, 1913; Smith and Mertie, 1930; Smith, 1933 (B844A); Smith, 1933 (B836); Holdsworth, 1952; Heiner and Wolff, 1968; Cobb, 1972 (MF 469); Cobb, 1973 (B1374); Cobb, 1976 (OF76-340); Cobb, 1981 (OF81-732).

Primary reference: Maddren, 1913

Reporter(s): J.M. Britton (Anchorage)

Last report date: $8 / 9 / 2002$ 


\section{Site name(s): Unnamed (headwaters of Malamute Fork John River)}

Site type: Occurrence

ARDF no.: WI058

Latitude: 67.3083

Quadrangle: WI B-5

Longitude: 152.3625

Location description and accuracy:

This occurrence is located along a southwest-flowing headwater tributary to the Malamute Fork, John River. It is about 4.5 miles southwest of the junction of Midas and Sixtymile Creeks. The occurrence is at an elevation of about 1,650 feet on the tributary, in the NE1/4 section 25, T. 29 N., R. 22 W., of the Fairbanks Meridian. The occurrence is the site of sample 519 in Dillon and others (1981 [AOF 133B]). The location is accurate within one-half mile.

\section{Commodities:}

Main: $\mathrm{Cu}, \mathrm{Pb}, \mathrm{Zn}$

Other: $\mathrm{As}, \mathrm{Sb}$

Ore minerals: Arsenopyrite, chalcopyrite, galena, pyrite, pyrrhotite, sphalerite

\section{Gangue minerals:}

\section{Geologic description:}

Two sources report $\mathrm{Cu}$ and $\mathrm{Pb}$ mineralization here. Dillon and others (1981, plate 1 [AOF 133B]) note a small area of $\mathrm{Cu}-\mathrm{Pb}$ mineralization. Grybeck (1977, locality. 31) reports an occurrence of stratiform $\mathrm{Cu}, \mathrm{Pb}$, and $\mathrm{Zn}$ mineralization approximately 1.5 miles southeast of the site shown by Dillon and others. These two mineral occurrences may be the same.

At sample locality 519 of Dillon and others (1981 [AOF 133B]), quartzite layers in marble and calcareous contains massive arsenopyrite and pyrite. These sulfides occur in bands that are parallel to the enclosing strata and are up to $10 \mathrm{~cm}$ thick and $20 \mathrm{~m}$ long. A sample contains $500 \mathrm{ppm}$ arsenic, $219 \mathrm{ppb}$ antimony, and $23 \%$ iron. Similar occurrences occur along strike for up to $1 \mathrm{~km}$. Grybeck (1977), citing unpublished industry data, reports pyrrhotite, galena, sphalerite, and chalcopyrite in interbedded schist, quartzite, and limestone. The rocks in the area consist of Devonian, Skajit Limestone and Middle to Upper Devonian black calcareous schist and dark limestone (Dillon and others, 1986).

\section{Alteration:}

\section{Age of mineralization:}

Deposit model:

Polymetallic replacement deposit (?) (Cox and Singer, 1986; model 19a)

Deposit model number (After Cox and Singer, 1986 or Bliss, 1992):

$19 \mathrm{a}(?)$

Production Status: None

Site Status: Inactive

Workings/exploration: 
Eight prospecting sites were located in the area in 1976 (Grybeck, 1977).

Production notes:

Reserves:

Additional comments:

References:

Grybeck, 1977; Dillon and others, 1981 (AOF 133B); Cobb, 1981 (OF81-732); Dillon and others, 1986; Bliss and others, 1988.

Primary reference: Dillon and others, 1981 (AOF 133B)

Reporter(s): J.M. Britton (Anchorage)

Last report date: $8 / 9 / 2002$ 


\section{Site name(s): Unnamed (on McKinley Creek)}

Site type: Occurrence

ARDF no.: WI059

Latitude: 67.4666

Quadrangle: WI B-5

Longitude: 152.2690

Location description and accuracy:

This occurrence is on McKinley Creek, approximately 7.5 miles northwest of the junction of McKinley Creek and John River, at an elevation of about 1,850 feet. The occurrence is the site of sample 20 of Dillon and others (1981 [AOF 133B]). The location is accurate.

\section{Commodities:}

Main: $\mathrm{As}, \mathrm{Pb}$

Other: $\mathrm{Cr}, \mathrm{Cu}(?), \mathrm{Ni}$

Ore minerals: Arsenopyrite, chalcopyrite, galena, pyrite

Gangue minerals:

\section{Geologic description:}

This occurrence is based on a float sample of fuchsite-quartz dolomite that contains about $1 \%$ disseminated arsenopyrite or galena, as well as pyrite cored by chalcopyrite (Dillon and others, 1981; sample 20 [AOF 133B])). A sample of this rock contains as much as 1,500 ppm arsenic, $200 \mathrm{ppm}$ lead, 1,500 ppm chromium, and $50 \mathrm{ppm}$ nickel. Sphalerite in float is also reported in an area about a mile to the west but the exact location is uncertain. The rocks in the area consist mostly of Devonian, Skajit Limestone (Dillon and others, 1986).

\section{Alteration:}

Age of mineralization:

Deposit model:

Deposit model number (After Cox and Singer, 1986 or Bliss, 1992):

Production Status: None

Site Status: Inactive

Workings/exploration:

Only surface sampling.

Production notes:

Reserves:

Additional comments:

References: 
Dillon and others, 1981 (AOF 133B); Bliss and others, 1988.

Primary reference: Dillon and others, 1981 (AOF 133B)

Reporter(s): J.M. Britton (Anchorage)

Last report date: $8 / 9 / 2002$ 
Site name(s): Unnamed (east of Wild Lake, opposite Seward Creek)

Site type: Occurrence

ARDF no.: WI060

Latitude: 67.4955

Quadrangle: WI B-4

Longitude: 151.5075

Location description and accuracy:

This occurrence is about 1.5 miles east of Wild Lake, east of the mouth of Seward Creek. It is at an elevation of about 3,450 feet at the northeast end of a small ridge, near the center of section 23, T. 31 N., R. 18 W., of the Fairbanks Meridian. The location is accurate.

\section{Commodities:}

Main: $\mathrm{Ag}, \mathrm{Au}, \mathrm{Cu}, \mathrm{Sb}$

Other:

Ore minerals: Malachite, tetrahedrite

Gangue minerals: Limonite, quartz

\section{Geologic description:}

This occurrence consists of oxidized and locally mineralized quartz veins in Devonian schist and phyllite (Chipp, 1972). Of three, selected samples of the veins, one contained malachite, one contained tetrahedrite, and one contained an unknown gray mineral (Chipp, 1972; Kurtak and others, 1999). The tetrahedrite-

bearing sample contains 6.5 ppm gold, 13 ppm silver, 2,400 ppm copper, and 2,000 ppm antimony (Chipp, 1972; sample 138). Analyses of the other samples showed no valuable metals. No other information is available.

\section{Alteration:}

Oxidation to limonite and malachite.

Age of mineralization:

\section{Deposit model:}

Polymetallic vein (?) (Cox and Singer, 1986; model 22c)

Deposit model number (After Cox and Singer, 1986 or Bliss, 1992): $22 c(?)$

Production Status: None

Site Status: Inactive

Workings/exploration:

Production notes:

Reserves:

Additional comments: 


\section{References:}

Chipp, 1972; Kurtak and others, 1999.

Primary reference: Chipp, 1972

Reporter(s): J.M. Britton (Anchorage)

Last report date: $8 / 9 / 2002$ 


\section{Site name(s): Lake Creek}

Site type: Mine

ARDF no.: WI061

Latitude: 67.4738

Quadrangle: WI B-4

Longitude: 151.5579

Location description and accuracy:

Lake Creek drains the area between Mathews Dome and Wild Lake; it empties into the east side of Wild Lake about 0.5 mile north of the south end of the lake. Mining on Lake Creek has mainly been in an area near the head of the alluvial fan on the lower part of the creek and on an area above a fork of the creek about 1.5 miles east of Wild Lake. The two areas are about 0.8 mile apart and the coordinates are given for the midpoint between them. The location is accurate within 1 mile.

\section{Commodities:}

Main: $\mathrm{Au}$

Other: $\mathrm{As}, \mathrm{Bi}, \mathrm{Cu}, \mathrm{Pt}, \mathrm{Sb}, \mathrm{W}$

Ore minerals: Bismuth (native), copper (native), gold, hematite, magnetite, platinum(?), pyrite, scheelite, stibnite

Gangue minerals: Quartz

Geologic description:

Gold was discovered on Lake Creek in 1903 (Maddren, 1913) and mining has continued intermittently through at least 1996 (Kurtak and others, 1999). Mining has been concentrated near the head of the alluvial fan where the creek enters Wild Lake and in a narrow portion of the creek valley about 1.5 miles east of the lake. Near the head of the alluvial fan, the depth to bedrock is 60 to 95 feet. In the upper valley of the creek, the depth to bedrock is only 3 feet. Reed (1938) reported production from early mining from 1904 to 1937 to be at least $\$ 26,000$ (about 1,300 ounces of gold) but he speculated that the extent of the workings indicated the production was many thousands of dollars more. No information is available on production since 1937.

The rocks in the area are predominantly muscovite-chlorite schist that contains numerous quartz lenses and veinlets (Kurtak and others,1999). Some of the quartz is parallel to the cleavage or schistosity, and some cross cuts it. Reed (1938) describes the bedrock about 200 feet above the last of the old workings (about 2 miles from the lake) as alternating micaceous and graphitic schist cut by a 300-feet-wide, greenstone schist dike. This greenstone dike was not observed by Kurtak and others (1999). Reed (1938) also noted soft reddish schist containing numerous quartz stingers at the head of Lake Creek. A sample of vein quartz from the Lake Creek drainage near the head of the alluvial fan contained minor chalcopyrite and tourmaline (Chipp, 1972, sample 133).

The gravels on Lake Creek are coarse and waterworn with numerous large schist boulders. The upper part of the gravel contains erratics of conglomerate and black chert. The gold occurs as coarse, waterworn nuggets, and as fine flour gold. Maddren (1913) noted recovery of nuggets valued at $\$ 90$ to $\$ 150$ ( about 4.7 to 7.9 ounces). Two estimates of the value of the ground in two separate locations along the creek are $\$ 1.86$ and \$2.50 per square foot of bedrock (Reed, 1938). Joesting (1943) lists several minerals in the placer concentrates from Lake Creek, including two, inch-long pieces of stibnite, scheelite, native bismuth, native copper, hematite, pyrite and magnetite. Sluice concentrates collected by the Kurtak and others (1999) contains up to 5,930 ppb platinum, 976 ppm tungsten, 976 ppm tungsten, $0.44 \%$ bismuth, 1,750 ppm arsenic, and 3,043 ppb gold. The sluice concentrates did not contain visible gold. Samples of quartz veins and the schist bedrock contain no valuable metals. 


\section{Alteration: \\ Age of mineralization: \\ Quaternary. \\ Deposit model: \\ Placer Au (Cox and Singer, 1986; model 39a) \\ Deposit model number (After Cox and Singer, 1986 or Bliss, 1992): \\ $39 \mathrm{a}$}

Production Status: Yes; small

Site Status: Active?

\section{Workings/exploration:}

Intermittent extensive mining by sluicing and drifting from 1904 through to at least 1996 (Kurtak and others, 1999).

Production notes:

Reed (1938) reported production from early mining from 1904 to 1937 to be at least $\$ 26,000$ (about 1,300 ounces of gold) but he speculated that the extent of the workings indicated the production was many thousands of dollars more. No information is available on production since 1937.

\section{Reserves:}

In 1986 a placer reserve of 10,000 ounces of gold was announced by the owners (Bundtzen and others, 1987).

\section{Additional comments:}

\section{References:}

Maddren, 1910; Maddren, 1913; Wimmler, 1925; Smith and Mertie, 1930; Smith, 1934 (B857A); Smith, 1936; Reed, 1938; Smith, 1939 (B917A); Joesting, 1942; Joesting, 1943; Thorne and others, 1948; Heiner and Wolff, 1968; Chipp, 1972; Cobb, 1972 (MF-469); Cobb, 1973 (B1374); Cobb, 1975 (MR-66); Cobb, 1976 (OF76-340); Grybeck, 1977; Cobb, 1981 (OF81-732); Dillon, 1982; Maas, 1987; Bundtzen and others, 1986; Bundtzen and others, 1987; Bundtzen and others, 1988; Bliss and others, 1988; Swainbank and others, 1991; Kurtak and others, 1999.

Primary reference: Reed, 1938

Reporter(s): J.M. Britton (Anchorage)

Last report date: $8 / 9 / 2002$ 


\section{Site name(s): Unnamed (ridge between Madison and Crevice Creeks)}

Site type: Occurrence

ARDF no.: WI062

Latitude: 67.3507

Quadrangle: WI B-4

Longitude: 151.6897

Location description and accuracy:

This occurrence is on a ridge between Crevice Creek and Madison Creek at an elevation of 3900 feet, near the center of section 12, T. 29 N., R. 19 W., of the Fairbanks Meridian. This is the site of sample 71 in Dillon and others (1981 [AOF 133B]). The location is accurate.

\section{Commodities:}

Main: $\mathrm{Cr}, \mathrm{Ni}$

Other: $\mathrm{Pb}, \mathrm{Zn}(?)$

Ore minerals: Arsenopyrite(?), sphalerite(?)

Gangue minerals:

Geologic description:

This occurrence consists of a fuchsite-muscovite-calcite quartzite (Dillon and others, 1981 [AOF 133B]) in Middle or Upper Devonian(?), chloritic and carbonate rocks (Dillon and others, 1986). A grab sample contains $1000 \mathrm{ppm}$ chromium, (probably attributable to the fuchsite) and $200 \mathrm{ppm}$ nickel, as well as 500 ppm arsenic, and $200 \mathrm{ppm}$ lead. The analytical data suggest that sphalerite and arsenopyrite might be present but neither was visible in the sample.

\section{Alteration:}

Age of mineralization:

Deposit model:

Deposit model number (After Cox and Singer, 1986 or Bliss, 1992):

Production Status: None

Site Status: Inactive

Workings/exploration:

Only surface sampling.

Production notes:

Reserves:

Additional comments:

References:

Dillon and others, 1981 (AOF 133B); Dillon and others, 1986; Bliss and others, 1988. 
Primary reference: Dillon and others, 1981 (AOF 133B)

Reporter(s): J.M. Britton (Anchorage)

Last report date: $8 / 9 / 2002$ 


\title{
Site name(s): Unnamed (upper Crevice Creek)
}

Site type: Occurrence

ARDF no.: WI063

Latitude: 67.3550

\author{
Quadrangle: WI B-4
}

Longitude: 151.8251

Location description and accuracy:

This occurrence is along the north fork of upper Crevice Creek about 5.5 miles east of the junction of Crevice Creek and John River. The occurrence is on the north side of the creek at an elevation of about 1,700 feet, about 0.6 mile northeast of the center of section 9, T. 29 N., R. 19 W., of the Fairbanks Meridian. The occurrence is the site of sample 257 of Dillon and others (1981 [AOF 133B]). The location is accurate.

\section{Commodities:}

Main: $\mathrm{As}, \mathrm{Cu}$

Other: $\mathrm{Co}, \mathrm{Pb}, \mathrm{V}, \mathrm{Zr}$

Ore minerals: Chalcopyrite, malachite

\section{Gangue minerals:}

\section{Geologic description:}

This occurrence consists of malachite-stained, calcareous, muscovite-quartz schist that contains finegrained, disseminated chalcopyrite (Dillon and others, 1981 [AOF133B]). A sample of schist contains 2,000 ppm copper, $500 \mathrm{ppm}$ arsenic, $300 \mathrm{ppm}$ cobalt, $200 \mathrm{ppm}$ lead, 1,000 ppm vanadium, and $500 \mathrm{ppm}$ zircon. The rocks in the area are Middle or Upper Devonian(?) chloritic and carbonate units (Dillon and others, 1986).

\section{Alteration:}

Age of mineralization:

\section{Deposit model:}

Deposit model number (After Cox and Singer, 1986 or Bliss, 1992):

Production Status: None

Site Status: Inactive

\section{Workings/exploration:}

Only surface sampling.

Production notes:

Reserves:

Additional comments: 


\section{References:}

Dillon and others, 1981 (AOF 133B); Dillon and others, 1986; Bliss and others, 1988.

Primary reference: Dillon and others, 1981 (AOF 133B)

Reporter(s): J.M. Britton (Anchorage)

Last report date: $8 / 9 / 2002$ 


\section{Site name(s): Crevice Creek}

Site type: Mine

ARDF no.: WI064

Latitude: 67.3635

Quadrangle: WI B-4

Longitude: 151.9292

Location description and accuracy:

Crevice Creek is a west-flowing tributary to John River; it is between McCamant Creek to the north and Bullrun Creek to the south. The mouth of Crevice Creek is approximately 0.5 mile south of the junction of the John and Allen Rivers. The center of the placer workings is about 3.5 miles upstream of the mouth of Crevice Creek, approximately at the eastern side of section 12, T. 29 N., R. 20 W., of the Fairbanks Meridian. The workings extend for about two miles upstream and downstream. The location is accurate.

\section{Commodities:}

Main: $\mathrm{Au}$

Other: $\mathrm{Ag}, \mathrm{Sb}(?)$

Ore minerals: Gold, magnetite, silver, stibnite(?)

\section{Gangue minerals:}

\section{Geologic description:}

Although he did not visit Crevice Creek in 1937, Reed (1938) noted that Crevice Creek flowed principally on bedrock and that the gold that was mined from potholes and crevices in the bedrock. Some of the gold-bearing crevices were several feet deep. Dillon (1982) mapped the rocks in the area as a schist-marble unit, and tentatively identified stibnite in the placer concentrates. Occasional native silver nuggets have been recovered with the gold (Kurtak and others, 2002). Panned-concentrate samples from Crevice Creek contain visible gold grains and abundant magnetite; a sample from a sluice-box concentrate has over 8,000 ppb gold (Kurtak and others, 1999). Bliss and others (1988) speculate that the gold is derived from sulfidebearing quartz veins in the Devonian Skajit limestone (see WI066). Analyses of seven gold samples from Crevice Creek gave median values of $4.2 \%$ silver, $0.14 \%$ copper, $0.008 \%$ lead, and $0.47 \%$ mercury, and a median fineness of 958. Three of these analyses showed detectable levels (but less than $2 \mathrm{ppm}$ ) of $\mathrm{Pd}$ (Mosier and Lewis, 1986).

Mining was reported as early as 1904 and the property was sluice mined in the 1980's (Bliss and others, 1988). The last year of significant mining on the creek was in 1994, followed by only minor suction dredging on the lower creek in 1998 (Kurtak and others, 2002). Approximately $\$ 1,800$ in gold (at $\$ 20.67$ per ounce) was said to have been produced in 1904 (Maddren, 1913). Dillon (1982) reports production of 30 ounces of gold per year, but it is unclear whether this production was historical or current as of 1982.

\section{Alteration:}

\section{Age of mineralization:}

Quaternary.

\section{Deposit model:}

Placer Au (Cox and Singer, 1986; model 39a)

Deposit model number (After Cox and Singer, 1986 or Bliss, 1992): $39 \mathrm{a}$ 
Production Status: Yes

Site Status: Active?

Workings/exploration:

Mining was reported as early as 1904 and the property was sluice mined in the 1980's (Bliss and others, 1988). The last year of significant mining on the creek was in 1994, followed by only minor suction dredging on the lower creek in 1998 (Kurtak and others, 2002).

\section{Production notes:}

Approximately $\$ 1,800$ in gold (at \$20.67 per ounce) was said to have been produced in 1904 (Maddren, 1913). Dillon (1982) reports production of 30 ounces of gold per year, but it is unclear whether this production was historical or current as of 1982.

\section{Reserves:}

\section{Additional comments:}

\section{References:}

Maddren, 1910; Maddren, 1913; Smith, 1913; Brooks, 1916; Smith and Mertie, 1930; Reed, 1938; Heiner and Wolff, 1968; Cobb, 1972 (MF-469); Cobb, 1976 (OF76-340); Grybeck, 1977; Bundtzen and others, 1982; Dillon, 1982; Eakins and others, 1983; Bundtzen and others, 1984; Mosier and Lewis, 1986; Maas, 1987; Bliss and others, 1988; Kurtak and others, 1999; Kurtak and others, 2002.

Primary reference: Dillon, 1982

Reporter(s): J.M. Britton (Anchorage)

Last report date: $8 / 9 / 2002$ 


\section{Site name(s): Unnamed (near Allen River)}

Site type: Occurrence

ARDF no.: WI065

Latitude: 67.3828

Quadrangle: WI B-4

Longitude: 151.9893

Location description and accuracy:

The occurrence is on Allen River, 0.4 mile downstream from the mouth of McCamant Creek. The occurrence is sample 237 in Dillon and others (1981 [AOF 133B]). The location is accurate within one-half mile.

Commodities:

Main: $\mathrm{Cu}, \mathrm{Zn}$

Other: $\mathrm{Ni}, \mathrm{Sn}(?), \mathrm{Ti}(?)$

Ore minerals: Cassiterite(?), chalcopyrite, copper sulfides (unspecified), rutile(?), sphalerite

Gangue minerals:

Geologic description:

Brosge and Reiser (1960) noted copper sulfides and malachite in Upper Devonian black phyllite and slate on the Allen River near the mouth of McCamant Creek. Dillon and others (1981, sample 237 [AOF 133B]) collected a sample of mineralized, metaclastic quartzite on Allen River less than 0.5 mile downstream from McCamant Creek. The sample contained disseminated(?) chalcopyrite and sphalerite, secondary malachite and azurite, and possibly rutile and cassiterite. A sample contains 5,000 ppm copper, $320 \mathrm{ppm}$ zinc, and 200 ppm nickel. The rocks in the area are Middle or Upper Devonian(?) phyllite and dolomite, with lesser metasandstone, marble, and conglomerate (Dillon and others, 1986).

\section{Alteration:}

Oxidation of copper minerals(s).

Age of mineralization:

\section{Deposit model:}

Polymetallic vein (?) (Cox and Singer, 1986; model 22c)

Deposit model number (After Cox and Singer, 1986 or Bliss, 1992): $22 \mathrm{c}(?)$

Production Status: None

Site Status: Inactive

Workings/exploration:

Only surface sampling.

Production notes:

Reserves: 
Additional comments:

\section{References:}

Brosge and Reiser, 1960; Cobb, 1972 (MF-469); Cobb, 1976 (OF76-340); Grybeck, 1977; Degenhart and others, 1978; Dillon and others, 1981 (AOF 133B); Maas, 1987; Bliss and others, 1988.

Primary reference: Dillon and others, 1981 (AOF 133B)

Reporter(s): J.M. Britton (Anchorage)

Last report date: $8 / 9 / 2002$ 


\section{Site name(s): Unnamed (lower Crevice Creek)}

Site type: Occurrence

ARDF no.: WI066

Latitude: 67.3554

Quadrangle: WI B-4

Longitude: 151.8983

Location description and accuracy:

This occurrence is on Crevice Creek, about 3.5 miles above its mouth. It is about 0.6 mile northwest of the center of section 7, T. 29 N., R. 20 W., of the Fairbanks Meridian, at an elevation of about 1,200 feet. The location is accurate.

\section{Commodities:}

Main: $\mathrm{Cu}, \mathrm{Pb}$

Other:

Ore minerals: Copper sulfides, galena, malachite

Gangue minerals: Quartz

Geologic description:

This occurrence is described by Brosge and Reiser (1960) as malachite-stained, vein quartz that contains galena and unspecified copper sulfides. The occurrence is in Devonian(?) Skajit Limestone, about 0.5 mile from a small mafic, igneous body.

\section{Alteration:}

Malachite staining.

Age of mineralization:

Deposit model:

Deposit model number (After Cox and Singer, 1986 or Bliss, 1992):

Production Status: None

Site Status: Inactive

Workings/exploration:

Production notes:

Reserves:

Additional comments:

\section{References:}

Brosge and Reiser, 1960; Cobb, 1972 (MF-469); Cobb, 1976 (OF76-340); Grybeck, 1977; Maas, 1987;

Bliss and others, 1988. 
Primary reference: Brosge and Reiser, 1960

Reporter(s): J.M. Britton (Anchorage)

Last report date: $8 / 9 / 2002$ 


\section{Site name(s): Luke Creek}

Site type: Occurrence

ARDF no.: WI067

Latitude: 67.4587

Quadrangle: WI B-4

Longitude: 151.6027

Location description and accuracy:

Luke Creek is not named on the Wiseman B-4 topographic map. It is described by Reed (1938) as a small creek that runs east to the head of Trout Lake, which also is unnamed on the current B-4 topographic map, but it is the lake immediately south of Wild Lake (Chipp, 1972). Of the two short creeks that enter Trout Lake from the west, the coordinates arbitrarily identify the northern one as Luke Creek. The site of the prospecting on this or the other of these creeks is unknown.

\section{Commodities:}

Main: $\mathrm{Au}$

Other:

Ore minerals: Gold

Gangue minerals:

Geologic description:

Reed (1938) reported placer gold prospects on Luke Creek. No other information is available.

Alteration:

Age of mineralization:

Quaternary.

Deposit model:

Placer Au (Cox and Singer, 1986; model 39a)

Deposit model number (After Cox and Singer, 1986 or Bliss, 1992):

$39 \mathrm{a}$

Production Status: None

Site Status: Inactive

Workings/exploration:

Prospecting only.

Production notes:

Reserves:

Additional comments:

References: 
Reed, 1938; Chipp, 1972; Cobb, 1976 (OF76-340); Maas, 1987.

Primary reference: Reed, 1938

Reporter(s): J.M. Britton (Anchorage)

Last report date: $8 / 9 / 2002$ 


\section{Site name(s): Mary's Creek}

Site type: Prospects

ARDF no.: WI068

Latitude: 67.4569

Quadrangle: WI B-4

Longitude: 151.6152

Location description and accuracy:

Mary's Creek is described by Reed (1938) as a small, right-limit tributary to Luke Creek ; it joins Luke Creek about a mile from Trout Lake. None of these features, which are south of Wild Lake, are named on the Wiseman B-4 topographic map. The locations of Luke Creek and Trout Lake are described on record WI067. There is little topographically to indicate a right limit tributary to Luke Creek. Somewhat arbitrarily, this occurrence is plotted at a small gully in the NW1/4 NE1/4 section 5, T, 30 N., R. 18 W., of the Fairbanks Meridian, and this location is probably no more than 1/2 mile from Mary's Creek.

\section{Commodities:}

Main: $\mathrm{Au}$

Other:

Ore minerals: Gold

Gangue minerals:

Geologic description:

Reed (1938) reported that very good prospects were said to have been found on this creek. No other information is available.

\section{Alteration:}

Age of mineralization:

Quaternary.

\section{Deposit model:}

Placer Au (Cox and Singer, 1986; model 39a)

Deposit model number (After Cox and Singer, 1986 or Bliss, 1992):

$39 \mathrm{a}$

Production Status: None

Site Status: Inactive

Workings/exploration:

Prospecting only.

Production notes:

Reserves:

Additional comments: 


\section{References:}

Reed, 1938; Cobb, 1976 (OF76-340); Cobb, 1981 (OF81-732).

Primary reference: Reed, 1938

Reporter(s): J.M. Britton (Anchorage)

Last report date: $8 / 9 / 2002$ 


\section{Site name(s): Unnamed (east side of lower Wild Lake)}

Site type: Occurrence

ARDF no.: WI069

Latitude: 67.4905

Quadrangle: WI B-4

Longitude: 151.5634

Location description and accuracy:

This occurrence is at an elevation of 1,500 feet on the east side of lower Wild Lake. It is about 0.6 mile southeast of the center of section 21, T. 31 N., R. 18 W., of the Fairbanks Meridian. The location is accurate within one-half mile.

\section{Commodities:}

Main: $\mathrm{Cu}$

Other:

Ore minerals: Copper sulfides (unspecified), malachite

Gangue minerals:

Geologic description:

Brosge and Reiser (1960) noted unspecified copper sulfides and malachite in Devonian calcareous schist. No other information is available.

\section{Alteration:}

Oxidation of copper mineral(s).

Age of mineralization:

Deposit model:

Deposit model number (After Cox and Singer, 1986 or Bliss, 1992):

Production Status: None

Site Status: Inactive

Workings/exploration:

Production notes:

Reserves:

Additional comments:

References:

Brosge and Reiser, 1960; Cobb, 1972 (MF-469); Cobb, 1976 (OF76-340).

Primary reference: Brosge and Reiser, 1960 
Reporter(s): J.M. Britton (Anchorage)

Last report date: $8 / 9 / 2002$ 


\section{Site name(s): Unnamed (between Crevice and McCamant Creeks)}

Site type: Occurrence

ARDF no.: WI070

Latitude: 67.3722

Quadrangle: WI B-4

Longitude: 151.9014

Location description and accuracy:

This occurrence is located on top of the ridge between Crevice and McCamant Creeks, about 2.3 miles southeast of the confluence of McCamant Creek and Allen River. The occurrence is at an elevation of about 2,700 feet in the NE1/4 section 1, T. 29 N., R. 20 W., of the Fairbanks Meridian. The site is sample 303 in Dillon and others (1981 [AOF 133B]). The location is accurate.

\section{Commodities:}

Main: $\mathrm{Cu}, \mathrm{Pb}$

Other:

Ore minerals: Galena, malachite

\section{Gangue minerals:}

Geologic description:

This occurrence consists of galena and malachite in maroon and white, muscovite quartzite (Dillon and others, 1981 [AOF 133B]). An analysis of a composite rock sample, however, showed no anomalous metal values. The rocks in the area consists of Devonian, Hunt Fork Shale near its thrust contact with overlying Devonian, Skajit Limestone (Dillon and others, 1986). A small area of Devonian(?) siliceous, clastic rocks is nearby. No other information is available.

\section{Alteration:}

Oxidation of copper mineral.

Age of mineralization:

Deposit model:

Deposit model number (After Cox and Singer, 1986 or Bliss, 1992):

Production Status: None

Site Status: Inactive

Workings/exploration:

Only surface sampling.

Production notes:

Reserves:

Additional comments: 


\section{References:}

Dillon and others, 1981 (AOF 133B); Dillon and others, 1986; Bliss and others, 1988.

Primary reference: Dillon and others, 1981 (AOF 133B)

Reporter(s): J.M. Britton (Anchorage)

Last report date: $8 / 9 / 2002$ 


\section{Site name(s): Unnamed (in headwater fork of Crevice Creek)}

Site type: Occurrence

ARDF no.: WI071

Latitude: 67.3959

Quadrangle: WI B-4

Longitude: 151.6788

Location description and accuracy:

This occurrence is on the divide at the head of the northern, headwater fork of Crevice Creek, and about 5 miles south-southwest of the south end of Wild Lake. The occurrence is at an elevation of about 4,000 feet, about 0.45 mile east-northeast of the center of section 25, T. 30 N., R. 19 W., of the Fairbanks Meridian. This occurrence is the site of sample 372 in Dillon and others (1981 [AOF 133B]). The location is accurate.

\section{Commodities:}

Main: $\mathrm{As}, \mathrm{Cu}$

Other: $\mathrm{Fe}, \mathrm{Mn}$

Ore minerals:

\section{Gangue minerals:}

Geologic description:

Dillon and others (1981 [AOF 133B]) collected a float sample of scoriaceous ferricrete at this location. The sample contains 2,000 ppm copper, 3,000 ppm arsenic, $5000 \mathrm{ppm}$ manganese, and 20\% iron. The ferricrete float covers an area of about 3 square meters and probably represents a weathered product of the underlying rocks. The occurrence is near the thrust contact between Devonian, Hunt Fork Shale and a unit of Devonian black calcareous phyllite and thin, dark limestone (Dillon and others, 1986).

\section{Alteration:}

Age of mineralization:

\section{Deposit model:}

Deposit model number (After Cox and Singer, 1986 or Bliss, 1992):

Production Status: None

Site Status: Inactive

Workings/exploration:

Only surface sampling.

Production notes:

Reserves:

Additional comments:

\section{References:}


Dillon and others, 1981 (AOF 133B); Dillon and others, 1986; Bliss and others, 1988.

Primary reference: Dillon and others, 1981 (AOF 133B)

Reporter(s): J.M. Britton (Anchorage)

Last report date: $8 / 9 / 2002$ 


\section{Site name(s): Unnamed (west of Twoday Mountain)}

Site type: Occurrence

ARDF no.: WI072

Latitude: 67.2698

Quadrangle: WI B-4

Longitude: 151.7400

Location description and accuracy:

This occurrence is between upper Timber and Suckik Creeks, about 5 miles south-southwest of Twoday Mountain. The occurrence is locality 88 of Dillon and others (1981 [AOF 133B]). It is at an elevation of about 3,950 feet, about 0.6 mile south-southeast of the center of section 4, T. 28 N., R. 19 W., of the Fairbanks Meridian. The location is accurate.

\section{Commodities:}

Main: $\mathrm{Zn}(?)$

Other:

Ore minerals: Pyrite(?), sphalerite

\section{Gangue minerals:}

Geologic description:

This occurrence consists of banded marble that locally contains layers with $10 \%$ sphalerite that replaces pyrite(?) (Dillon, 1981 [AOF 133B]). However, a grab sample from outcrop, contains only $25 \mathrm{ppm} \mathrm{Zn}$ and no other anomalous metal values. The rocks in the area are Devonian(?) or older(?), black slate, phyllite, and limestone (Bliss and others, 1988). No other information is available.

\section{Alteration:}

Age of mineralization:

Deposit model:

Deposit model number (After Cox and Singer, 1986 or Bliss, 1992):

Production Status: None

Site Status: Inactive

Workings/exploration:

Only surface sampling.

Production notes:

Reserves:

Additional comments:

References:

Dillon and others, 1981 (AOF 133B) ; Bliss and others, 1988. 
Primary reference: Dillon and others, 1981(AOF 133B)

Reporter(s): J.M. Britton (Anchorage)

Last report date: $8 / 9 / 2002$ 


\title{
Site name(s): Unnamed (west of lower Wild Lake)
}

Site type: Occurrence

ARDF no.: WI073

Latitude: 67.4788

\author{
Quadrangle: WI B-4
}

Longitude: 151.6843

Location description and accuracy:

This occurrence is about 2.5 miles west-northwest of the outlet at the south end of Wild Lake. The occurrence is at an elevation of 3,650 feet, about 0.3 mile south-southeast of the center of section 25, T. 31 N., R. 19 W., of the Fairbanks Meridian. The occurrence is the site of sample 130 of Chipp (1972). The location is accurate.

\section{Commodities:}

Main: $\mathrm{Ag}, \mathrm{Cu}$

Other:

Ore minerals: Malachite, unspecified sulfides

Gangue minerals: Quartz

Geologic description:

This occurrence consists of locally mineralized quartz veins in dolomite (Chipp, 1972). A selected sample of quartz with unspecified sulfides and malachite contains $2,100 \mathrm{ppm}$ copper and $2.4 \mathrm{ppm}$, silver. A second sample of vein quartz, taken approximately 0.2 miles to the north, contains malachite but no elevated metal values. The rocks in the vicinity are Devonian schist and phyllite (Chipp, 1972). No other information is available.

\section{Alteration:}

Oxidation of copper mineral(s).

Age of mineralization:

\section{Deposit model:}

Deposit model number (After Cox and Singer, 1986 or Bliss, 1992):

Production Status: None

Site Status: Inactive

Workings/exploration:

Only surface sampling.

Production notes:

Reserves:

Additional comments: 


\section{References:}

Chipp, 1972; Cobb, 1976 (OF76-340); Bliss and others, 1988.

Primary reference: Chipp, 1972

Reporter(s): J.M. Britton (Anchorage)

Last report date: $8 / 9 / 2002$ 


\section{Site name(s): Moose Trail}

Site type: Occurrence

ARDF no.: WI074

Latitude: 67.3990

Quadrangle: WI B-4

Longitude: 151.9942

Location description and accuracy:

This occurrence is located about 1 mile north of the junction of McCamant Creek and Allen River. The occurrence is at an elevation of about 1,650 feet, 0.3 mile north-northwest of the center of section 27, T. 30 N., R. 20 W., of the Fairbanks Meridian. The location is accurate within 1 mile.

\section{Commodities:}

Main: $\mathrm{Cu}$

Other:

Ore minerals:

Gangue minerals:

Geologic description:

Almost no information is available for this occurrence. The location of the occurrence is given in the U.S. Bureau of Mine's MAS database and is shown by Maas (1987). Dillon (1981, Plate 1 [AOF 133B]) indicates that the area contains copper mineralization. The rocks in the area are principally Devonian(?) chloritic and carbonate rocks (Dillon and others, 1986). No other information is available.

\section{Alteration:}

Age of mineralization:

Deposit model:

Deposit model number (After Cox and Singer, 1986 or Bliss, 1992):

Production Status: None

Site Status: Inactive

Workings/exploration:

Production notes:

Reserves:

Additional comments:

See also: Allen River; Allen (WI065).

References:

Dillon and others, 1981 (AOF 133B); Dillon and others, 1986; Maas, 1987; Kurtak and others, 2002. 
Primary reference: Dillon and others, 1981 (AOF 133B)

Reporter(s): J.M. Britton (Anchorage)

Last report date: $8 / 9 / 2002$ 


\section{Site name(s): Unnamed (east of Gunsight Mountain)}

Site type: Occurrence

ARDF no.: WI075

Latitude: 67.4908

Quadrangle: WI B-4

Longitude: 151.8671

Location description and accuracy:

This occurrence is west of Allen River, about 4.5 miles northeast of Gunsight Mountain. The occurrence is at an elevation of about 2,750 feet in the SE1/4 section 19, T. 31 N., R. 19 W., of the Fairbanks Meridian. The location is accurate within one-half mile.

\section{Commodities:}

Main: $\mathrm{Cu}$

Other:

Ore minerals: Copper sulfides (unspecified), malachite

Gangue minerals:

Geologic description:

This occurrence consists of copper sulfides and malachite staining in a Devonian pebble conglomerate that is below the contact between a basal, phyllite and slate unit that been overthrust by Devonian, Skajit Limestone (Brosge and Reiser, 1960). No other information is available.

Alteration:

Oxidation of copper mineral(s).

Age of mineralization:

Deposit model:

Deposit model number (After Cox and Singer, 1986 or Bliss, 1992):

Production Status: None

Site Status: Inactive

Workings/exploration:

Only surface sampling.

Production notes:

Reserves:

Additional comments:

References:

Brosge and Reiser, 1960; Cobb, 1972 (MF-469); Cobb, 1976 (OF76-340); Bliss and others, 1988. 
Primary reference: Brosge and Reiser, 1960

Reporter(s): J.M. Britton (Anchorage)

Last report date: 8/9/2002 


\section{Site name(s): Birch Creek}

Site type: Mine

ARDF no.: WI076

Latitude: 67.4445

Quadrangle: WI B-3

Longitude: 151.3413

Location description and accuracy:

Birch Creek is a west-flowing tributary of Flat Creek. Their junction is about 3 miles southeast of Mathews Dome and about 6 miles east-southeast of the south end of Wild Lake. Mining in the early 1900's occurred along about 1 mile of the stream on either side of the mouth of a south-flowing unnamed tributary to Birch Creek whose mouth is about 1.25 miles above the mouth of Birch Creek. The mine is centered on Birch Creek at the mouth of this tributary at the southeast corner of section 4, T. 30 N., R. 17 W., of the Fairbanks Meridian. The location is accurate.

\section{Commodities:}

Main: $\mathrm{Au}$

Other:

Ore minerals: Gold

\section{Gangue minerals:}

\section{Geologic description:}

Gold was discovered on Birch Creek in 1904 by Louis Rue (Reed, 1938). He reportedly recovered about $\$ 1,800$ in gold in 1905 (gold at \$20.67 per ounce) (Reed, 1938). The modern channel of Birch Creek has been mined for about 1/2 mile above and below the mouth of Rue Creek, a name reported by Reed (1938), but not shown on the modern topographic map. Rue Creek is a south-flowing tributary to Birch Creek that enters Birch Creek about 1.25 miles above the mouth of Birch Creek. The gravel is coarse and waterworn in Birch Creek and contains many boulders. An area along the left limit of Birch Creek below Rue Creek was drift mined. The depth of the drift workings is probably about 20 feet, similar to the depth to bedrock in the creek bed (Reed, 1938). Several shafts were also sunk in the alluvial fan where Birch Creek enters the valley of Flat Creek but the results of this work are not known.

Birch Creek was mined by shoveling-in and drifting. Reed, (1938) noted that mining had not occurred on this creek since 1933. Reed estimated the total production from the early 1900's until about 1933 to be $\$ 20,000$ to $\$ 30,000$ (at the old price of gold at $\$ 20.67$ per ounce). A placer operation on Birch Creek in 1998 was mining stream gravel with dozers and then allowed paying customers to pan, sluice, dredge or use gold detectors to recover gold from the gravels (Kurtak and others, 1999).

A sample of quartz-mica schist from the ridge on the north side of upper Birch Creek contains $35 \mathrm{ppb}$ gold and 1,767 ppm arsenic (Kurtak and others, 1999).

\section{Alteration:}

Age of mineralization:

Quaternary.

Deposit model:

Placer Au (Cox and Singer, 1986; model 39a)

Deposit model number (After Cox and Singer, 1986 or Bliss, 1992): 
$39 a$

Production Status: Yes; small

Site Status: Active?

Workings/exploration:

Birch Creek was mined by shoveling-in and drifting. Reed, (1938) noted that mining had not occurred on this creek since 1933. More recently, until 1998, Paradise Mining operated on Birch Creek, including a tourist-oriented recreational mining concession.

\section{Production notes:}

Gold was discovered on Birch Creek in 1904 by Louis Rue. He reportedly recovered about $\$ 1,800$ in gold in 1905 (gold at \$20.67 per ounce) (Reed, 1938). Reed (1938) estimated the total production from the early 1900 's until about 1933 to be $\$ 20,000$ to $\$ 30,000$ (at the old price of gold at $\$ 20.67$ per ounce. A placer operation on Birch Creek in 1998 was mining stream gravel with dozers and then allowing paying customers to pan, sluice, dredge or use gold detectors to recover gold from the gravels (Kurtak and others, 1999).

\section{Reserves:}

\section{Additional comments:}

\section{References:}

Maddren, 1910; Maddren, 1913; Brooks, 1918; Brooks and Martin, 1921; Smith and Mertie, 1930; Reed, 1938; Heiner and Wolff, 1968; Cobb, 1972 (MF-469); Cobb, 1976 (OF76-340); Grybeck, 1977; Maas, 1987; Bliss and others, 1988; Green and others, 1989; Bundtzen and others, 1990; Swainbank and others, 1991; Bundtzen and others, 1994; Swainbank and others, 1995; Bundtzen and others, 1996; Swainbank and others, 1997; Swainbank and others, 1998; Kurtak and others, 1999; Szumigala and Swainbank, 1999; Swainbank and others, 2000.

Primary reference: Reed, 1938

Reporter(s): J.M. Britton (Anchorage)

Last report date: $8 / 9 / 2002$ 


\section{Site name(s): Unnamed (near junction of Fall and Michigan Creeks)}

Site type: Occurrence

ARDF no.: WI077

Latitude: 67.3015

Quadrangle: WI B-3

Longitude: 151.2446

Location description and accuracy:

This occurrence is the locations of several rock samples in an area about 0.2 mile in diameter (Dillon and others, 1981; Plate 1, samples 467 to 472 and 474 and 475 [AOF 133B]). The area is about 6 miles southwest of Ipnek Mountain and about 0.2 mile northwest of the junction of Fall and Michigan Creeks. The occurrence is at an elevation of about 1,550 feet, 0.4 mile south-southwest of the center of section 25, T. 29 N., R. 17 W., of the Fairbanks Meridian. The location is accurate.

\section{Commodities:}

Main: $\mathrm{As}, \mathrm{Au}, \mathrm{Cu}$

Other: $\mathrm{Ag}, \mathrm{Co}, \mathrm{Pb}, \mathrm{Ti}, \mathrm{Zn}$

Ore minerals: Arsenopyrite, cassiterite, chalcopyrite, marcasite, molybdenite(?), pyrite, pyrrhotite, rutile, sphalerite

Gangue minerals: Quartz

\section{Geologic description:}

Dillon and others (1981 [AOF 133B]) collected mineralized rock samples at several sites in an area of about a half mile in diameter. The mineralization occurs in layers and veins of massive pyrrhotite, chalcopyrite, sphalerite, arsenopyrite, cassiterite, rutile, pyrite and possible molybdenite. The pyrrhotite is partly altered to marcasite. Eight samples collected by Dillon and others contain up to 82,000 ppm arsenic, 700 ppm cobalt, 1,360 ppm copper, 8.28 ppm gold, 135 ppm lead, 50 ppm tin, and 329 ppm zinc. The sulfide layers and veins are up to $30 \mathrm{~cm}$. thick in actinolite-biotite felsite interlayered with marble and garnetquartz-albite-muscovite schist. Hornfelsed calc-silicate rocks along the contact with the felsite contain disseminated pyrite(?). Dillon and others (1986) map the area as Devonian and Devonian(?) interlayered felsic and mafic intrusive and extrusive rocks, locally mixed with clastic sedimentary rocks. They indicate that the upper Devonian felsic schist is regionally associated with copper deposits.

Alteration:

Alteration of pyrrhotite to marcasite; oxidation of sulfides.

Age of mineralization:

Deposit model:

Polymetallic vein(?) (Cox and Singer, 1986; model 22c)

Deposit model number (After Cox and Singer, 1986 or Bliss, 1992): $22 \mathrm{c}(?)$

Production Status: None

Site Status: Inactive 
Workings/exploration:

Only surface sampling.

Production notes:

Reserves:

Additional comments:

References:

Dillon and others, 1981 (AOF 133B); Dillon and others, 1986; Bliss and others, 1988.

Primary reference: Dillon and others, 1981 (AOF 133B)

Reporter(s): J.M. Britton (Anchorage)

Last report date: $8 / 9 / 2002$ 


\section{Site name(s): Agnes Creek}

Site type: Occurrence

ARDF no.: WI078

Latitude: 67.4694

Quadrangle: WI B-3

Longitude: 151.3940

Location description and accuracy:

Agnes Creek is a west-flowing tributary to upper Flat Creek, about 6 or 7 miles east of Wild Lake. The junction of Flat and Agnes Creeks is about 4 miles northeast of Mathews Dome. The extent of the placer is unknown and the occurrence is arbitrarily located about a mile upstream from the mouth of Agnes Creek.

\section{Commodities:}

Main: $\mathrm{Au}$

Other:

Ore minerals: Gold

Gangue minerals:

Geologic description:

Reed (1938) noted that there had been extensive prospecting and some mining on Agnes Creek in the early 1900's, but that records of the mining had been lost.

\section{Alteration:}

Age of mineralization:

Quaternary.

Deposit model:

Placer Au (Cox and Singer, 1986; model 39a)

Deposit model number (After Cox and Singer, 1986 or Bliss, 1992):

$39 \mathrm{a}$

Production Status: Undetermined.

Site Status: Inactive

Workings/exploration:

Prospecting and some mining in the early 1900's.

Production notes:

Reserves:

Additional comments:

References:

Reed, 1938; Cobb, 1976 (OF76-340); Cobb, 1981 (OF81-732); Maas, 1987; Bundtzen and others, 1990. 
Primary reference: Reed, 1938

Reporter(s): J.M. Britton (Anchorage)

Last report date: $8 / 9 / 2002$ 


\section{Site name(s): Unnamed (northwest of head of Jay Creek)}

Site type: Occurrence

ARDF no.: WI079

Latitude: 67.4231

Quadrangle: WI B-3

Longitude: 151.2809

Location description and accuracy:

This occurrence is located about 6 miles southeast of Mathews Dome and 2 miles northeast of the junction of Jay and Rye Creeks. The occurrence is at an elevation of about 4,000 feet, at about the center of section 14, T. 30 N., R. 17 W., of the Fairbanks Meridian. The location is accurate.

\section{Commodities:}

Main: $\mathrm{Cu}$

Other: Ag, Mo

Ore minerals: Chalcopyrite, magnetite, tetrahedrite(?)

Gangue minerals:

Geologic description:

This occurrence consists of sulfide-bearing greenschist. Dillon and others (1981, sample 477 [AOF 133B]) collected a rock sample of fine-grained greenschist containing disseminated chalcopyrite and possibly tetrahedrite. The sample contains $11.0 \mathrm{ppm}$ silver, $1,360 \mathrm{ppm}$ copper, and $320 \mathrm{ppm}$ molybdenum. A rubble sample collected by the Bureau of Land Management at this location consists of greenschist with disseminated chalcopyrite and magnetite, but no tetrahedrite (Kurtak and others, 1999, Plate 1, Map no. 93). They also collected an outcrop sample of quartz-chlorite-magnetite schist. Analyses of these samples shows no valuable metals.

\section{Alteration:}

Age of mineralization:

\section{Deposit model:}

Polymetallic vein (?) (Cox and Singer, 1986; model 22c)

Deposit model number (After Cox and Singer, 1986 or Bliss, 1992): $22 \mathrm{c}(?)$

Production Status: None

Site Status: Inactive

Workings/exploration:

Only surface sampling.

Production notes:

Reserves: 
Additional comments:

\section{References:}

Dillon and others, 1981 (AOF 133B); Bliss and others, 1988; Kurtak and others, 1999.

Primary reference: Dillon and others, 1981 (AOF 133B)

Reporter(s): J.M. Britton (Anchorage)

Last report date: $8 / 9 / 2002$ 


\section{Site name(s): Unnamed (south of lower Michigan Creek)}

Site type: Occurrence

ARDF no.: WI080

Latitude: 67.2801

Quadrangle: WI B-3

Longitude: 151.2847

Location description and accuracy:

This occurrence is south of lower Michigan Creek feet about 3 miles east-northeast of the junction of Michigan Creek and Wild River. The occurrence is at an elevation of 1,850 feet about 0.5 mile westnorthwest of the center of section 3, T. 28 N., R. 17 W., of the Fairbanks Meridian. The location is accurate.

\section{Commodities:}

Main: Zn

Other: As

Ore minerals: Pyrite, sphalerite

Gangue minerals: Quartz

Geologic description:

This occurrence consists of sulfide-bearing quartz veins and sulfides disseminations in greenschist. Dillon and others (1981, samples 52 and 402 [AOF 133B]) collected two samples of greenschist, one with thin quartz and pyrite veins, and one containing disseminated pyrite and traces of sphalerite in veins. One sample contained $500 \mathrm{ppm}$ arsenic. The rocks in the vicinity consist of metabasite (Dillon and others, 1986).

\section{Alteration:}

Age of mineralization:

Deposit model:

Deposit model number (After Cox and Singer, 1986 or Bliss, 1992):

Production Status: None

Site Status: Inactive

Workings/exploration:

Only surface sampling.

Production notes:

Reserves:

Additional comments:

References:

Dillon and others, 1981 (AOF 133B); Dillon and others, 1986; Maas, 1987; Bliss and others, 1988. 
Primary reference: Dillon and others, 1981(AOF 133B)

Reporter(s): J.M. Britton (Anchorage)

Last report date: $8 / 9 / 2002$ 


\section{Site name(s): Unnamed (ridge east of Scofield Creek)}

Site type: Occurrence

ARDF no.: WI081

Latitude: 67.3278

Quadrangle: WI B-3

Longitude: 151.3112

Location description and accuracy:

This occurrence is between Scofield and Michigan Creeks, about 7.5 miles west of Ipnek Mountain and 2.8 miles northeast of the junction of Scofield Creek and Wild River. The occurrence is at an elevation of about 3,550 feet, about 0.5 mile north-northeast of the center of section 22, T. 29 N., R. 17 W., of the Fairbanks Meridian. The location is accurate.

\section{Commodities:}

Main: $\mathrm{Ag}, \mathrm{Pb}, \mathrm{Zn}$

Other: As, $\mathrm{Ba}, \mathrm{Fe}$

Ore minerals:

\section{Gangue minerals:}

Geologic description:

This occurrence consists of a gossan zone at the contact of calc-schist and marble with granite. A sample of float from the gossan contains up to $20 \mathrm{ppm}$ silver, $1,000 \mathrm{ppm}$ arsenic, 1,500 ppm lead, 1,800 ppm zinc, $20 \%$ iron, and $0.5 \%$ barium. (Dillon and others, 1981, sample 380 [AOF 133B]). No sulfides were observed in the sample. Kurtak and others (2002) collected a sample of limonite-stained muscovite schist float in this area that contains $129 \mathrm{ppm}$ lead, and $391 \mathrm{ppm}$ arsenic.

About a mile to the west, Dillon and others (1981, no. 127) collected a sample of quartz-monzonite gneiss in contact with calc-schist and skarn. This sample contains about $3 \%$ unspecified, partly oxidized, sulfides, apparently of replacement origin. This sample contains about $200 \mathrm{ppm}$ lanthanum but no other anomalous metal values. The rocks in the area are granite gneiss of the Devonian Wild River Pluton, which intrudes Proterozoic or lower Paleozoic(?) schist of varying types with some marble. (Dillon and others, 1986).

Alteration:

Iron-staining.

Age of mineralization:

Deposit model:

Zn-Pb skarn deposit(?) (Cox and Singer, 1986; model 18c)

Deposit model number (After Cox and Singer, 1986 or Bliss, 1992): $18 \mathrm{c}(?)$

Production Status: None

Site Status: Inactive

Workings/exploration:

Six claims (EPI 1-6) were located by Canevex, Inc. in this area in 1975 but no other information on the 
claims is available (Kurtak and others, 2002).

Production notes:

Reserves:

Additional comments:

References:

Dillon and others, 1981 (AOF 133B); Dillon and others, 1986; Bliss and others, 1988; Kurtak and others, 2002.

Primary reference: Dillon and others, 1981 (AOF 133B)

Reporter(s): J.M. Britton (Anchorage)

Last report date: $8 / 9 / 2002$ 


\section{Site name(s): Jay Creek; Eagle Gulch}

Site type: Mine

ARDF no.: WI082

Latitude: 67.4050

Quadrangle: WI B-3

Longitude: 151.3191

Location description and accuracy:

Jay Creek is a southwest-flowing tributary of Rye Creek; it is about 6 miles southeast of Mathews Dome. This mine is about $1 / 2$ mile above the mouth of Jay Creek. Eagle Gulch, which is unnamed on the Wiseman B-3 topographic map, is a small, right-limit tributary to Jay Creek. Although the exact location of the placer workings on Jay Creek is not known, Reed (1938) noted that the claims extended from No. 1 Below Discovery (which reached about 500 feet into the Rye Creek valley) to No. 5 Above Discover, and that the creek was mined from the mouth to the lower reaches of No. 5 Above Discovery claim. The location is accurate.

\section{Commodities:}

Main: $\mathrm{Au}$

Other: $\mathrm{Cu}, \mathrm{Sb}$

Ore minerals: Chalcopyrite, gold, pyrite

Gangue minerals: Quartz

Geologic description:

Gold was discovered on Jay Creek in 1904 but mining did not begin until 1912 (Reed, 1938). Jay Creek is reputed to be the richest creek in the Wild River district. Jay Creek is in a canyon that averages about 50 feet wide. Brooks (1916) reported that the paystreak was 30 feet wide and 4 feet thick. Reed (1938) describes the gravel as thawed, very coarse grained with subangular sediments, 3 to 12 feet thick , and contains numerous erratic, conglomerate boulders. The gold occurs throughout the gravel and in the upper foot of the bedrock. The gold is coarse grained, unworn, very dark colored, and about 970 fine. Dillon (1982) reports a stibnite-quartz vein upstream from the placer, and Bliss and others (1988) speculated that the source of the gold is stibnite(?)-quartz veins within the drainage. The rocks in the vicinity consist of alternating bands of graphitic schist, micaceous schist, and greenstone schist (Reed, 1938). A little gold was found in Jay Creek near the mouth of Eagle Gulch, a locally named, small, right-limit tributary to Jay Creek (Reed, 1938).

A chip sample of a quartz vein with pyrite and chalcopyrite in the upper drainage of Jay Creek contains 21 ppb gold and 82 ppm arsenic (Kurtak and others, 1999; sample no. 95).

See also Rye Creek (WI084).

\section{Alteration:}

Age of mineralization:

Quaternary.

Deposit model:

Placer Au (Cox and Singer, 1986; model 39a)

Deposit model number (After Cox and Singer, 1986 or Bliss, 1992):

$39 \mathrm{a}$ 
Production Status: Yes; small

Site Status: Probably inactive

Workings/exploration:

From 1912 through at least 1935, the creek was mined by booming and shoveling into sluice boxes. Mining took place over 5 or 6 claim lengths from the mouth of the creek to the lower part of No. 5 Above Discovery. A mechanized mining operation was active on Jay Creek in 1998.

\section{Production notes:}

The estimated total production from Jay Creek through 1935 is about $\$ 200,000$ (approximately 10,000 oz.). The ground that was mined had an average value of about $\$ 0.505$ per square foot of bedrock (gold at $\$ 35$ per ounce) (Reed, 1938). There is no information available about recent mining.

\section{Reserves:}

\section{Additional comments:}

\section{References:}

Brooks, 1916; Smith, 1917; Brooks, 1918; Brooks, 1922; Smith and Mertie, 1930; Reed, 1938; Heiner and Wolff, 1968; Cobb, 1973 (B1374); Cobb, 1976 (OF76-340); Grybeck, 1977; Dillon, 1982; Mosier and Lewis, 1986; Bliss and others, 1988; Swainbank and others, 1991; Kurtak and others, 1999.

Primary reference: Reed, 1938

Reporter(s): J.M. Britton (Anchorage)

Last report date: $8 / 9 / 2002$ 


\section{Site name(s): Silver King}

Site type: Prospect

ARDF no.: WI083

Latitude: 67.2863

Quadrangle: WI B-3

Longitude: 151.3213

Location description and accuracy:

The Silver King prospect is along the north side of Michigan Creek about 2 miles east of Wild River and 8.75 miles southwest of Ipnek Mountain. It is at an elevation of about 1,100 feet, 0.3 mile west of the top of hill 1370, in the SW1/4 section 34, T. 29 N., R. 17 W., of the Fairbanks Meridian. The location is accurate.

\section{Commodities:}

Main: $\mathrm{Ag}, \mathrm{Au}, \mathrm{Cu}, \mathrm{Pb}, \mathrm{Zn}$

Other: As

Ore minerals: Chalcopyrite, galena (argentiferous), pyrite

Gangue minerals: Ankerite, quartz, siderite(?)

\section{Geologic description:}

Early descriptions of the Silver King prospect, beginning with Schrader in 1904, described this occurrence as argentiferous galena-bearing quartz veins in phyllite. Reed (1938) described several poorly exposed outcrops and float of galena-bearing quartz-vein material along about 2,000 feet of Michigan Creek. Reed described the rocks along Michigan Creek as a dark phyllite that grades to slate. Outcrops of the quartz veins, although at times inaccessible due to steep terrain, are about 5 to 6 feet thick, strike northeasterly, and dip steeply northwest.

More recent descriptions of the occurrence note a more varied mineral assemblage. Nokleberg and others (1987) characterize the occurrence as a Kuroko massive sulfide deposit. They describe the mineralization as 3- to 4-inch thick zones of disseminated to massive chalcopyrite and argentiferous galena in felsic schist, with crosscutting pyrite veins. The country rocks are felsic schist, marble and phyllite of the Devonian and Mississippian, Ambler sequence. Grab samples of the mineralized material contain up to $8.2 \%$ arsenic, 8.3 grams of gold per ton, 3.9 grams of silver per ton, $0.14 \%$ copper, $0.03 \%$ zinc, and $0.014 \%$ lead.

Kurtak and others (1999) collected and analyzed several float samples of mineralized material from near the Silver King prospect . The samples are limonite-stained vein quartz with galena, ankerite and siderite (?). Selected samples contain up to $4.35 \%$ lead, 2.63 ounces of silver per ton, $118 \mathrm{ppm}$ antimony, and $9 \mathrm{ppb}$ gold.

\section{Alteration:}

Iron staining.

\section{Age of mineralization:}

\section{Deposit model:}

Kuroko massive sulfide(?) (Cox and Singer, 1986; model 28a)

Deposit model number (After Cox and Singer, 1986 or Bliss, 1992): $28 \mathrm{a}(?)$ 
Production Status: None

Site Status: Inactive

Workings/exploration:

A 7x7 foot adit, 75 feet long, has been driven into the north wall of the canyon of Michigan Creek, probably to undercut a vein exposed in a surface trench about 150 feet north and 100 feet higher than the portal of the adit. This adit was caved in 1999 (Kurtak and others, 1999).

\section{Production notes:}

\section{Reserves:}

\section{Additional comments:}

\section{References:}

Schrader, 1904; Brooks, 1923; Smith and Mertie, 1930; Reed, 1938; Wedow and others, 1953; Brosge and Reiser, 1960; Berg and Cobb, 1967; Heiner and Wolff, 1968; Cobb, 1972 (MF-469); Cobb, 1976 (OF76340); Grybeck, 1977; Dillon and others, 1981 (AOF 133B); Maas, 1987; Nokleberg and others, 1987; Bliss and others, 1988; Nokleberg and others, 1996; Kurtak and others, 1999; Kurtak and others, 2002.

Primary reference: Nokleberg and others, 1987

Reporter(s): J.M. Britton (Anchorage)

Last report date: $8 / 9 / 2002$ 


\section{Site name(s): Rye Creek}

Site type: Mine

ARDF no.: WI084

Latitude: 67.4092

Quadrangle: WI B-3

Longitude: 151.3745

Location description and accuracy:

Rye Creek is west-flowing tributary to Flat Creek that joins it about 4 miles south-southwest of Mathews Dome. The mine is on Rye Creek at the west edge of section 21, T. 30 N., R. 17 W., of the Fairbanks Meridian. It is about 0.5 mile upstream from the approximate lower limit of placer mining; placer mining extended upstream to the mouth of Jay Creek (WI082). The location is accurate.

\section{Commodities:}

Main: $\mathrm{Au}$

Other: $\mathrm{Cu}, \mathrm{Pb}, \mathrm{REE}, \mathrm{W}$

Ore minerals: Chalcopyrite, galena, gold, ilmenite, monazite, pyrite, scheelite

\section{Gangue minerals:}

\section{Geologic description:}

Placer gold was found at Rye Creek in 1915 (Brooks, 1916) and subsequently gold was mined from the modern channel, a high channel, and a deep channel (Reed, 1938). The total production from Rye Creek as of 1938 was about $\$ 55,000$ (approx. 2,700 oz.). Nearly half of that was recovered from a 300-foot section of the modern channel below the mouth of Jay Creek (WI082) (Reed, 1938). Mining on the modern channel extended from near the mouth of Jay Creek downstream to where Rye Creek enters Flat Creek valley. A high channel occurs along the right limit of lower Rye Creek, about 0.2 mile north of the modern creek, but it apparently contained little gold. A deep channel also occurs along the right limit of Rye Creek. A shaft was sunk 85 feet to bedrock beside lower Rye Creek and the deep channel was drift mined for a short distance. Additional drift mining was conducted on the deep channel about 0.2 mile below Jay Creek, where the depth to bedrock is about 20 feet. The gravel in Rye Creek is angular, very coarse grained, and contains numerous small boulders. Gold in paying amounts in Rye Creek has not been found above the mouth of Jay Creek. Reed (1938) reports that the bedrock on lower Rye Creek to about 0.5 mile below the mouth of Jay Creek is blue crystalline limestone; above this point, the bedrock is schist. He suspects a fault contact between these two units. Dillon and others (1986) map most of the area around Rye Creek as Skajit Limestone; the uppermost part of the creek flows across chloritic and carbonate rocks. White (1951) reported various accessory minerals in panned samples from Rye Creek; these include ilmenite, andalusite, kyanite, pyrite, zircon, chalcopyrite, monazite, galena, and scheelite.

\section{Alteration:}

\section{Age of mineralization:}

Quaternary.

\section{Deposit model:}

Placer Au (Cox and Singer, 1986; model 39a)

Deposit model number (After Cox and Singer, 1986 or Bliss, 1992): $39 a$ 
Production Status: Yes

Site Status: Probably inactive

Workings/exploration:

The modern channel of Rye Creek was mined by hand methods; the deep channel was drift mined. Kurtak and others (2002) reported mining on Rye Creek and Jay Creek (WI082) as late as 1999.

\section{Production notes:}

Reed (1938) reported that total gold production from Rye Creek to 1938 was $\$ 55,000$ (approximately 1,600 ounces). Nearly half of that was recovered from a short section just below Jay Creek (WI082) where the gold values were about $\$ 3.35$ per square foot of bedrock (gold at \$35 per ounce).

\section{Reserves:}

\section{Additional comments:}

See also Jay Creek (WI082).

\section{References:}

Brooks, 1916; Brooks, 1918; Reed, 1938; White, 1952; Overstreet, 1967; Heiner and Wolff, 1968; Cobb, 1972 (MF-469); Cobb, 1973 (B1374); Cobb, 1976 (OF76-340); Cobb, 1981 (OF81-732); Dillon, 1982; Maas, 1987; Bliss and others, 1988; Kurtak and others, 2002.

Primary reference: Reed, 1938

Reporter(s): J.M. Britton (Anchorage)

Last report date: $8 / 9 / 2002$ 


\section{Site name(s): Unnamed (south of Mathews Dome)}

Site type: Occurrence

ARDF no.: WI085

Latitude: 67.4437

Quadrangle: WI B-3

Longitude: 151.4779

Location description and accuracy:

This occurrence is located about 1.5 miles south of Mathews Dome. It is at near a prominent peak an elevation of about 4,000 feet in the NW1/4 section 12, T. 30 N., R. 18 W., of the Fairbanks Meridian. The location is accurate.

\section{Commodities:}

Main: $\mathrm{Ag}, \mathrm{Au}, \mathrm{Zn}$

Other: $\mathrm{Pb}$

Ore minerals: Pyrite, sphalerite

Gangue minerals:

Geologic description:

This occurrence consists of replacement layers or veins of sphalerite and pyrite up to $8 \mathrm{~cm}$ thick in an orange-weathering dolomite layer in gray marble (Dillon and others, 1981 [AOF 133B]. A grab sample of the mineralized rock contains 0.40 ppm gold, 2.2 ppm silver, $200 \mathrm{ppm}$ lead, and $10.3 \%$ zinc. High values of $\mathrm{Mg}$ and $\mathrm{Mn}$ were also noted.

Alteration:

Age of mineralization:

Deposit model:

Polymetallic replacement deposit(?) (Cox and Singer, 1986; model 19a)

Deposit model number (After Cox and Singer, 1986 or Bliss, 1992): $19 \mathrm{a}(?)$

Production Status: None

Site Status: Inactive

Workings/exploration:

Only surface sampling.

Production notes:

Reserves:

Additional comments:

References: 
Dillon and others, 1981 (AOF 133B); Bliss and others, 1988.

Primary reference: Dillon and others, 1981 (AOF 133B)

Reporter(s): J.M. Britton (Anchorage)

Last report date: $8 / 9 / 2002$ 


\section{Site name(s): Unnamed (near Mathews Dome)}

Site type: Occurrence

ARDF no.: WI086

Latitude: 67.4836

Quadrangle: WI B-3

Longitude: 151.3095

Location description and accuracy:

This occurrence represents several rock samples taken over a distance of about 2000 feet immediately north of the summit of Mathews Dome. The occurrence is centered at about an elevation of about 4,100 feet,on the ridge about 0.2 mile north-northwest of the 4618-foot peak of Mathews Dome. The location is accurate.

\section{Commodities:}

Main: $\mathrm{Au}, \mathrm{Ag}, \mathrm{Cu}$

Other:

Ore minerals: Bornite, malachite, tetrahedrite(?)

Gangue minerals: Calcite, quartz

Geologic description:

This occurrence consists of bornite, malachite, and possibly tetrahedrite in quartz veins, altered calcschist, and schist; the rocks in the area consist of Devonian phyllite, schist, and subordinate limestone/ dolomite (Chipp, 1972). Seven samples contain up to $0.1 \mathrm{ppm}$ gold, $14 \mathrm{ppm}, \mathrm{m}$ silver, and $2.1 \%$ copper. No other information is available on this occurrence.

\section{Alteration:}

Oxidation of copper mineral(s). One sample of a calc-schist is described as altered, but no description of the alteration is available.

Age of mineralization:

\section{Deposit model:}

Polymetallic vein(?) (Cox and Singer, 1986; model 22c)

Deposit model number (After Cox and Singer, 1986 or Bliss, 1992): $22 \mathrm{c}(?)$

Production Status: None

Site Status: Inactive

Workings/exploration:

Field examination of mineralization and analysis of grab samples.

Production notes:

Reserves: 
Additional comments:

\section{References:}

Chipp, 1972; Cobb, 1976 (OF76-340); Grybeck, 1977; Cobb, 1981 (OF81-732); Dillon and others, 1981 (AOF 133B); Maas, 1987; Bliss and others, 1988; Kurtak and others, 1999.

Primary reference: Chipp, 1972

Reporter(s): J.M. Britton (Anchorage)

Last report date: $8 / 9 / 2002$ 


\section{Site name(s): Unnamed (north of Mathews Dome)}

Site type: Occurrence

ARDF no.: WI087

Latitude: 67.4687

Quadrangle: WI B-3

Longitude: 151.3928

Location description and accuracy:

This occurrence is about 0.6 mile north of the summit of Mathews Dome. It is at an elevation of about 4,000 feet near the southwest corner of section 25, T. 31 N., R. 18 W., of the Fairbanks Meridian. The location is accurate.

\section{Commodities:}

Main: $\mathrm{Ag}, \mathrm{Cu}$

Other:

Ore minerals: Malachite

Gangue minerals: Quartz

\section{Geologic description:}

This occurrence consists of traces of malachite in quartz veins and schist (Chipp, 1972). Selected grab sample of schist contain $2.1 \%$ copper and $14.0 \mathrm{ppm}$ silver. A sample of vein quartz contained no anomalous values. (Samples 501 and 502 of Dillon and others (1981 [AOF 133B]) are the same as samples 136 and 137 of Chipp (1972) that are cited above.). The rocks in the area are Devonian phyllite, schist, and subordinate limestone or dolomite (Chipp, 1972).

\section{Alteration:}

Oxidation of copper mineral.

Age of mineralization:

Deposit model:

Deposit model number (After Cox and Singer, 1986 or Bliss, 1992):

Production Status: None

Site Status: Inactive

Workings/exploration:

Only surface sampling.

Production notes:

Reserves:

Additional comments:

See also Mathews Dome (WI086). 


\section{References:}

Chipp, 1972; Dillon and others, 1981 (AOF 133B); Bliss and others, 1988.

Primary reference: Chipp, 1972

Reporter(s): J.M. Britton (Anchorage)

Last report date: $8 / 9 / 2002$ 


\section{Site name(s): East Creek}

Site type: Occurrence

ARDF no.: WI088

Latitude: 67.3658

Quadrangle: WI B-3

Longitude: 151.1651

Location description and accuracy:

East Creek originates near Ipnek Mountain and flows west to Michigan Creek. The junction of East and Michigan Creeks is about 5.2 miles northwest of Ipnek Mountain. The location of the placer occurrence along East Creek is not known and this occurrence is arbitrarily placed about a mile upstream from the mouth of the creek.

\section{Commodities:}

Main: $\mathrm{Au}$

Other:

Ore minerals: Gold, magnetite

\section{Gangue minerals:}

Geologic description:

Although Reed (1938) did not visit East Creek, he reports that it drains an area of schist and that very good placer prospects were found along it in the early 1900's.

Alteration:

Age of mineralization:

Quaternary.

Deposit model:

Placer Au (Cox and Singer, 1986; model 39a)

Deposit model number (After Cox and Singer, 1986 or Bliss, 1992):

$39 \mathrm{a}$

Production Status: None

Site Status: Inactive

Workings/exploration:

Possibly only some prospecting.

Production notes:

Reserves:

Additional comments:

References: 
Reed, 1938; Cobb, 1976 (OF76-340); Maas, 1987; Kurtak and others, 2002.

Primary reference: Reed, 1938

Reporter(s): J.M. Britton (Anchorage)

Last report date: $8 / 9 / 2002$ 


\section{Site name(s): Fall Creek}

Site type: Prospects

ARDF no.: WI089

Latitude: 67.2918

Quadrangle: WI B-3

Longitude: 151.2077

Location description and accuracy:

Fall Creek is a west-flowing tributary to Michigan Creek; its mouth is about 6 miles southwest of Ipnek Mountain. The exact locations of placer prospects on Fall Creek are unknown and the site is arbitrarily placed approximately 1 mile upstream from its mouth.

\section{Commodities:}

Main: $\mathrm{Au}$

Other:

Ore minerals: Gold

Gangue minerals:

Geologic description:

Reed (1938) did not visit visit Fall Creek but was told that it flowed entirely over schist and that very good prospects had been found on it in the early 1900's. No other information is available on these prospects.

Alteration:

Age of mineralization:

Quaternary.

Deposit model:

Placer Au (Cox and Singer, 1986; model 39a)

Deposit model number (After Cox and Singer, 1986 or Bliss, 1992):

$39 \mathrm{a}$

Production Status: None

Site Status: Inactive

Workings/exploration:

Prospecting only.

Production notes:

Reserves:

Additional comments:

\section{References:}


Reed, 1938; Cobb, 1976 (OF 76-340).

Primary reference: Reed, 1938

Reporter(s): J.M. Britton (Anchorage)

Last report date: $8 / 9 / 2002$ 


\section{Site name(s): Bourbon Creek}

Site type: Mine

ARDF no.: WI090

Latitude: 67.2794

Quadrangle: WI B-3

Longitude: 151.1609

Location description and accuracy:

Bourbon Creek is not named on the Wiseman B-3 topographic map. Reed (1938) describes Bourbon Creek as a left-limit tributary of Fall Creek. Later publications (Cobb (1972 [MF469]); Maas, 1987; Bliss and others, 1988) placed Bourbon Creek about 2.5 miles upstream from the mouth of Fall Creek although at least two other tributaries farther upstream could correspond to Reed's description. This mine is somewhat arbitrarily located near the mouth of the tributary in the NW1/4 section 6, T. 28 N., R. 16 W., of the Fairbanks Meridian.

\section{Commodities:}

Main: $\mathrm{Au}$

Other:

Ore minerals: Gold

Gangue minerals:

Geologic description:

The only information about this placer deposit is that it was extensively mined in the early 1900's and was considered to have been mined out by 1937 (Reed, 1938).

\section{Alteration:}

Age of mineralization:

Quaternary.

Deposit model:

Placer Au (Cox and Singer, 1986; model 39a)

Deposit model number (After Cox and Singer, 1986 or Bliss, 1992):

$39 \mathrm{a}$

Production Status: Yes

Site Status: Inactive

Workings/exploration:

Bourbon Creek was extensively mined in the early 1900's.

Production notes:

Reserves:

Additional comments: 


\section{References:}

Reed, 1938; Cobb, 1972 (MF-469); Cobb, 1976 (OF76-340); Grybeck, 1977; Maas, 1987; Bliss and others, 1988.

Primary reference: Reed, 1938

Reporter(s): J.M. Britton (Anchorage)

Last report date: $8 / 9 / 2002$ 


\section{Site name(s): Kay Creek}

Site type: Occurrence

ARDF no.: WI091

Latitude: 67.4204

Quadrangle: WI B-3

Longitude: 151.1703

Location description and accuracy:

Kay Creek is not named on the Wiseman B-3 topographic map. The only information on the location of Kay Creek is a report by Reed (1938) that describes Kay Creek as a small, southeast-flowing, right-limit tributary of Michigan Creek that heads against Jay Creek. Kay Creek is most likely the small drainage about 3 miles above the junction of East and Michigan Creeks and about 8 miles east-southeast of Mathews Dome. There is, however, nothing that describes the location of any workings on this creek. This occurrence is arbitrarily located a short distance upstream from the mouth of the northern of the two unnamed creeks in the S1/2 section 17, T. 30 N., R. 16 W., of the Fairbanks Meridian.

\section{Commodities:}

Main: $\mathrm{Au}$

Other:

Ore minerals: Gold

Gangue minerals:

\section{Geologic description:}

The only information available on this prospect is that some mining and considerable prospecting was done, probably prior to 1910 (Reed, 1938).

\section{Alteration:}

Age of mineralization:

Quaternary.

\section{Deposit model:}

Placer Au (Cox and Singer, 1986; model 39a)

Deposit model number (After Cox and Singer, 1986 or Bliss, 1992):

$39 \mathrm{a}$

Production Status: Undetermined.

Site Status: Inactive

Workings/exploration:

Extensive prospecting which resulted in some mining prior to 1910 (Reed, 1938).

Production notes:

Reserves: 
Additional comments:

\section{References:}

Reed, 1938; Cobb, 1972 (MF-469); Cobb, 1976 (OF76-340); Maas, 1987; Bliss and others, 1988.

Primary reference: Reed, 1938

Reporter(s): J.M. Britton (Anchorage)

Last report date: $8 / 9 / 2002$ 


\section{Site name(s): Lucky Creek}

Site type: Prospects

ARDF no.: WI092

Latitude: 67.3913

Quadrangle: WI B-3

Longitude: 151.2917

Location description and accuracy:

Lucky Creek does not appear on the B-3 topographic map but it is a local name for the northeast continuation of Rye Creek. The point where Rye Creek supposedly becomes Lucky Creek is unclear but is assumed to be a point about 1 mile southeast of the mouth of Jay Creek. The location of placer prospects on Lucky Creek is not known and these prospects are somewhat arbitrarily located on the creek at an elevation of about 1,950 feet in the SW1/4 section 26, T. 30 N., R. 17 W., of the Fairbanks Meridian.

\section{Commodities:}

Main: $\mathrm{Au}$

Other:

Ore minerals: Gold

\section{Gangue minerals:}

Geologic description:

According to Reed (1938), Lucky Creek, flows entirely on schist. It was extensively prospected in the early 1900 's, with recovery of small amounts of gold. However, there is no information to suggest any significant mining.

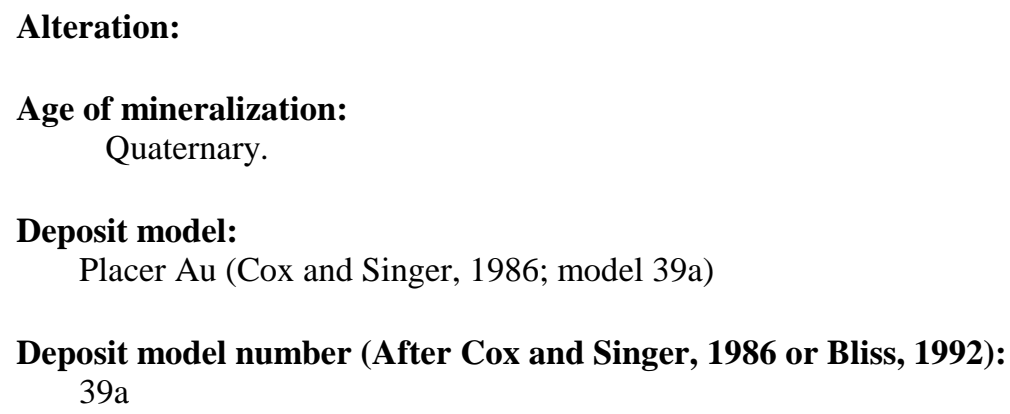

Deposit model:

Placer Au (Cox and Singer, 1986; model 39a)

Deposit model number (After Cox and Singer, 1986 or Bliss, 1992):

$39 \mathrm{a}$

Production Status: None

Site Status: Inactive

Workings/exploration:

Prospecting only.

Production notes:

Reserves:

Additional comments: 


\section{References:}

Reed, 1938; Cobb, 1976 (OF76-340); Grybeck, 1977.

Primary reference: Reed, 1938

Reporter(s): J.M. Britton (Anchorage)

Last report date: $8 / 9 / 2002$ 


\section{Site name(s): Oregon Creek}

Site type: Prospects

ARDF no.: WI093

Latitude: 67.4429

Quadrangle: WI B-3

Longitude: 151.4761

Location description and accuracy:

Oregon Creek is not named on the Wiseman B-3 topographic map. It is a small right-limit tributary to Flat Creek. The mouth of Oregon Creek is located about 1.5 miles north of the junction of Birch and Flat Creeks. The location of placer prospects on Oregon Creek is not known and the site is plotted just upstream from the mouth of the creek in about the center of section 32, T. 31 N., R. 17 W., of the Fairbanks Meridian.

\section{Commodities:}

Main: $\mathrm{Au}$

Other:

Ore minerals: Gold

\section{Gangue minerals:}

\section{Geologic description:}

Reed (1938) reported that good placer prospects had been found on Oregon Creek but that there had been no mining. Reed described the bedrock on Oregon Creek as schist; Dillon and others (1986) map the area as Upper Devonian(?), Hunt Fork Shale and Middle Devonian(?) siliceous clastic rocks.

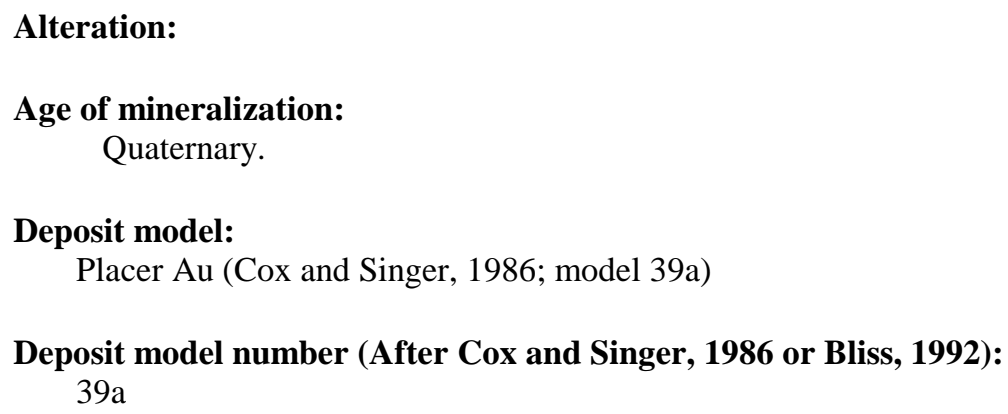

Site Status: Inactive

Workings/exploration:

Prospecting but no mining.

Production notes:

Reserves:

Additional comments: 


\section{References:}

Reed, 1938; Cobb, 1972 (MF-469); Cobb, 1976 (OF76-340); Cobb, 1981 (OF81-732); Dillon and others, 1986; Maas, 1987.

Primary reference: Reed, 1938

Reporter(s): J.M. Britton (Anchorage)

Last report date: $8 / 9 / 2002$ 


\section{Site name(s): Conglomerate Creek}

Site type: Occurrence

ARDF no.: WI094

Latitude: 67.4846

Quadrangle: WI B-2

Longitude: 150.6758

Location description and accuracy:

Conglomerate Creek is a southeast-flowing tributary to Glacier River. Its mouth is approximately 2 miles east of Delay Pass and 5.5 miles northwest of Bluecloud Mountain. There is little information to locate this placer occurrence along Conglomerate Creek and the site is arbitrarily plotted about 0.2 mile east of the center of section 28, T. 31 N., R. 14 W., of the Fairbanks Meridian, based on the location shown in Dillon (1982).

\section{Commodities:}

Main: $\mathrm{Au}$

Other:

Ore minerals: Gold, magnetite, pyrite

\section{Gangue minerals:}

\section{Geologic description:}

Although he did not visit Conglomerate Creek, Reed (1938) reported that very good prospects were found on it in the early 1900's. Bliss and others (1988) indicated that there was some activity in the 1980's. The mining is s hampered by large conglomerate boulders in the creek. Mosier and Lewis (1986) analyzed six samples of yellow gold from Conglomerate Creek. Panned samples collected by Kurtak and others (1999) contained no visible gold although one sample contained $250 \mathrm{ppb}$ gold. Only one pan contained any metallic minerals, chiefly traces of magnetite and some pyrite.

\section{Alteration:}

Age of mineralization:

Quaternary.

Deposit model:

Placer Au (Cox and Singer, 1986; model 39a)

Deposit model number (After Cox and Singer, 1986 or Bliss, 1992):

$39 \mathrm{a}$

Production Status: Undetermined.

Site Status: Probably inactive

Workings/exploration:

Reed (1938) noted reports of mining on this creek, and Bliss and others (1988) indicated that there was some activity in the 1980's.

Production notes: 


\section{Reserves:}

Additional comments:

Bureau of Land Management lists the locality as Cinco Mining (U. S. Bureau of Mines, 1998; Kurtak and others, 1999).

\section{References:}

Reed, 1938; Cobb, 1976 (OF76-340); Dillon, 1982; Mosier and Lewis, 1986; Bliss and others, 1988; U.S. Bureau of Mines, 2000; Kurtak and others, 1999.

Primary reference: Reed, 1938

Reporter(s): J.M. Britton (Anchorage)

Last report date: $8 / 9 / 2002$ 


\section{Site name(s): Big Four Creek}

Site type: Occurrence

ARDF no.: WI095

Latitude: 67.4980

Quadrangle: WI B-2

Longitude: 150.6976

Location description and accuracy:

The location of this occurrence is uncertain. The only description is that Big Four Creek is a left-limit tributary to Conglomerate Creek between Conglomerate Creek and Mascot Creek (Reed, 1938). This could be one of several left-limit tributaries to Conglomerate Creek. This location is arbitrarily placed near the mouth of the largest of the left-limit tributaries of Conglomerate Creek, at the east edge of the SE1/4 section 20, T. 31 N., R. 14 W., of the Fairbanks Meridian.

Big Four Creek is given as an alternate name for Bonanza Creek in the U. S. Bureau of Mines Minerals Availability System data (U.S. Bureau of Mines, 2000). Their location also differs from Reed's (1938) location for Big Four Creek. The Reed location is used here.

\section{Commodities:}

Main: $\mathrm{Au}$

Other:

Ore minerals: Gold

Gangue minerals:

\section{Geologic description:}

Schrader (1904) reported mining in 1902. Reed (1938) noted that mining in the early days was small scale, but reports that there was no activity in 1937. No additional information is available.

\section{Alteration:}

Age of mineralization:

Quaternary.

Deposit model:

Placer Au (Cox and Singer, 1986; model 39a)

Deposit model number (After Cox and Singer, 1986 or Bliss, 1992):

$39 \mathrm{a}$

Production Status: Yes

Site Status: Inactive

Workings/exploration:

Reed (1938) reported no activity in 1937.

Production notes:

Reed (1938) notes that mining in the early days was small scale. 


\section{Reserves:}

Additional comments:

\section{References:}

Schrader, 1904; Reed, 1938; U.S. Bureau of Mines, 2000.

Primary reference: Reed, 1938

Reporter(s): J.M. Britton (Anchorage)

Last report date: $8 / 9 / 2002$ 


\section{Site name(s): Minnie Creek}

Site type: Prospects

ARDF no.: WI096

Latitude: 67.3939

Quadrangle: WI B-1

Longitude: 150.1494

Location description and accuracy:

Minnie Creek is a west-flowing tributary to the Middle Fork, Koyukuk River. It joins the Middle Fork about 0.75 mile north of Wiseman. Only the lower three miles or so of Minnie Creek are in the Wiseman quadrangle; the remainder of it's approximately 9-mile length is to the east in the Chandalar quadrangle. Although most indications of placer activity are on the part of the creek in the Chandalar quadrangle, the exact location of prospecting and/or mining are uncertain. This prospects are arbitrarily placed approximately 1 mile upstream from the mouth of Minnie Creek.

\section{Commodities:}

Main: $\mathrm{Au}$

Other:

Ore minerals: Gold

\section{Gangue minerals:}

\section{Geologic description:}

Minnie Creek reportedly was heavily prospected and locally drift mined in the early 1900's, but it is unclear as to exactly where on Minnie Creek this activity occurred (Reed, 1938). Water problems hindered excavation to bedrock and the early mining efforts were not very successful (Reed, 1938). A shaft to bedrock in 1904 reportedly produced $\$ 500$ of 'shot' gold from a short drift before it was flooded. Drift mining was concentrated in a deep channel, although some gold was taken out at higher levels. No prospects were reported on the modern channel or on a high channel, although several high benches indicate the presence of a high channel. Limited evidence suggests that most mining activity on Minnie Creek has been on the middle and upper parts of the creek in the Chandalar quadrangle, although it is likely that at least some prospecting has occurred along the lower portion of the creek in the Wiseman quadrangle. A pannedconcentrate sample from upper Minnie Creek (in the Wiseman quadrangle) contained 6,899 ppb gold (Kurtak and others, 1999).

\section{Alteration:}

Age of mineralization:

Quaternary.

\section{Deposit model:}

Placer Au (Cox and Singer, 1986; model 39a)

Deposit model number (After Cox and Singer, 1986 or Bliss, 1992): $39 \mathrm{a}$

Production Status: Yes; small

Site Status: Inactive 


\section{Workings/exploration:}

Considerable prospecting and some drifting was reported in the early 1900's, but water above bedrock made prospecting and drift mining difficult (Mulligan, 1974).

Production notes:

$\$ 1,000$ worth of gold (about 49 ounces) was produced by 1909 (Maddren, 1913).

\section{Reserves:}

\section{Additional comments:}

\section{References:}

Maddren, 1910; Brooks, 1913; Maddren, 1913; Brooks, 1918; Smith, 1933 (B836); Reed, 1938; Heiner and Wolff, 1968; Brosge and Reiser, 1972; Cobb, 1972 (MF-469); Mulligan, 1974; Cobb, 1976 (OF76-340);

Dillon, 1982; Orris and Bliss, 1985; Dillon, 1987; Maas, 1987; Bliss and others, 1988.

Primary reference: Reed, 1938

Reporter(s): J.M. Britton (Anchorage)

Last report date: $8 / 9 / 2002$ 


\section{Site name(s): Lofty Gulch; Lofty Creek}

Site type: Mine

ARDF no.: WI097

Latitude: 67.4865

Quadrangle: WI B-1

Longitude: 150.0925

Location description and accuracy:

Lofty Gulch is a short, steep, south tributary to the lower Hammond River, between Swift Creek and Gold Bottom Gulch. Placer mining has occurred from near the mouth of Lofty Gulch for a distance of about 1,500 feet upstream. The mine is plotted at an elevation of about 1,350 feet near the mouth of the gulch. The location is accurate.

\section{Commodities:}

Main: $\mathrm{Au}$

Other:

Ore minerals: Gold

\section{Gangue minerals:}

Geologic description:

The modern channel of Lofty Gulch was mined near its mouth in the early 1900's (Reed, 1938). There has been no mining on the upper parts of the creek, where it is narrow, steep and contains only limited amounts of gravel in which gold could occur. According to Reed (1938), the creek was mined out.

\section{Alteration:}

Age of mineralization:

Quaternary.

Deposit model:

Placer Au (Cox and Singer, 1986; model 39a)

Deposit model number (After Cox and Singer, 1986 or Bliss, 1992):

$39 \mathrm{a}$

Production Status: Yes; small

Site Status: Inactive

\section{Workings/exploration:}

There was limited mining near the mouth of Lofty Gulch.

Production notes:

Reserves:

Additional comments: 


\section{References:}

Reed, 1938; Mulligan, 1974; Cobb, 1976 (OF76-340); Maas, 1987; Kurtak and others, 1999.

Primary reference: Reed, 1938

Reporter(s): J.M. Britton (Anchorage)

Last report date: $8 / 9 / 2002$ 


\section{Site name(s): Union Gulch; Union Creek}

Site type: Mine

ARDF no.: WI098

Latitude: 67.4241

Quadrangle: WI B-1

Longitude: 150.1516

Location description and accuracy:

Union Gulch flows east and southeast off the southeast side of Midnight Dome; it is about 3 miles north of Wiseman. Maddren (1913) noted that placer gold deposits on this creek were limited to about one claim but he did not specify the exact location of this claim. Eden (2000) indicates that the placer gold deposits were about 0.8 mile upstream from the mouth of Union Gulch, which is at an elevation of about 1,300 feet. The location is accurate within one-half mile.

\section{Commodities:}

Main: $\mathrm{Au}$

Other:

Ore minerals: Gold

\section{Gangue minerals:}

\section{Geologic description:}

Placer gold deposits on Union Gulch are limited to the modern stream channel (Reed, 1938). Gold was discovered in 1901 when a 32 ounce nugget was recovered. Maddren (1913) reported \$35,000 of gold (about 1850 oz.) produced from 1900 through 1909, with $\$ 30,000$ of that produced in 1902. Mining was reported in 1934 and 1937, but Mulligan (1974) indicated that the property was inactive as of 1974. Bliss and others (1986) reported some mining activity from 1980 to 1982 and Szumigala and Swainbank (1999) reported production from Union Gulch in 1998. The gold is coarse and at a shallow depth (Heiner and Wolff, 1968). Three, panned-concentrate samples from Union Gulch contained abundant magnetite, some sulfides, and one very fine gold particle (Kurtak and others, 1999). All of these panned-concentrate samples were geochemically anomalous in gold (Kurtak and others, 1999). The rocks in the area consist of quartzite, quartz-mica schist and phyllite (Eden, 2000).

Maddren (1913) reported \$35,000 of gold about 1,850 oz.) produced from 1900 through 1909, with $\$ 30,000$ of that produced in 1902. Mining was reported in 1934 and 1937, but Mulligan (1974) indicated that the property was inactive as of 1974. Bliss and others (1986) reported some mining activity from 1980 to 1982 and Szumigala and Swainbank (1999) reported production from Union Gulch in 1998.

\section{Alteration:}

Age of mineralization:

Quaternary.

Deposit model:

Placer Au (Cox and Singer, 1986; model 39a)

Deposit model number (After Cox and Singer, 1986 or Bliss, 1992):

$39 a$

Production Status: Yes; small 
Site Status: Active?

Workings/exploration:

Maddren (1913) reported $\$ 35,000$ of gold about 1,850 oz.) produced from 1900 through 1909, with $\$ 30,000$ of that produced in 1902. Mining was reported in 1934 and 1937, but Mulligan (1974) indicated that the property was inactive as of 1974. Bliss and others (1986) reported some mining activity from 1980 to 1982 and Szumigala and Swainbank (1999) reported production from Union Gulch in 1998.

\section{Production notes:}

Maddren (1913) reported \$35,000 (about 1,850 oz.) of gold produced from 1900 through 1909 with $\$ 30,000$ of that produced in 1902. Mining was reported in 1934 and 1937, but Mulligan (1974) indicated that the property was inactive as of 1974. Bliss and others (1986) reported some mining activity from 1980 to 1982 and Szumigala and Swainbank (1999) reported production from Union Gulch in 1998.

\section{Reserves:}

\section{Additional comments:}

\section{References:}

Schrader, 1904; Maddren, 1910; Maddren, 1913; Smith, 1936; Reed, 1938; Heiner and Wolff, 1968; Cobb, 1972 (MF-469); Cobb, 1973 (B1374); Mulligan, 1974; Cobb, 1976 (OF76-340); Grybeck, 1977; Dillon, 1982; Eakins and others, 1983; Bundtzen and others, 1984; Maas, 1987; Bliss and others, 1988; Swainbank and others, 1993; Bundtzen and others, 1994; Swainbank and others, 1998; Kurtak and others, 1999; Szumigala and Swainbank, 1999; Eden, 2000; Swainbank and others, 2000; Kurtak and others, 2002.

Primary reference: Reed, 1938

Reporter(s): J.M. Britton (Anchorage)

Last report date: $8 / 9 / 2002$ 


\section{Site name(s): Confederate Gulch}

Site type: Prospects

ARDF no.: WI099

Latitude: 67.4631

Quadrangle: WI B-1

Longitude: 150.0885

Location description and accuracy:

Confederate Gulch is a small drainage west of the Middle Fork, Koyukuk River; it is about 3.5 miles north-northeast of Wiseman. Placer prospecting extends from the coordinates given above where the creek enters the valley of the Middle Fork, Koyukuk River, and continues upstream for about 4,000 feet. The location is accurate.

\section{Commodities:}

Main: $\mathrm{Au}$

Other:

Ore minerals: Gold

Gangue minerals:

Geologic description:

Confederate Gulch was prospected extensively in the early 1900's and some coarse gold was recovered during prospecting (Maddren, 1913). The amount of gold, however, was insufficient to justify intensive mining.

\section{Alteration:}

Age of mineralization:

Quaternary.

Deposit model:

Placer Au (Cox and Singer, 1986; model 39a)

Deposit model number (After Cox and Singer, 1986 or Bliss, 1992):

$39 a$

Production Status: None

Site Status: Inactive

Workings/exploration:

Prospecting only.

Production notes:

Reserves:

Additional comments: 


\section{References:}

Maddren, 1913; Reed, 1938; Heiner and Wolff, 1968; Cobb, 1972 (MF-469); Mulligan, 1974; Cobb, 1976 (OF76-340); Maas, 1987.

Primary reference: Maddren, 1913

Reporter(s): J.M. Britton (Anchorage)

Last report date: $8 / 9 / 2002$ 


\section{Site name(s): Buckeye Gulch; Buckeye Creek}

Site type: Mine

ARDF no.: WI100

Latitude: 67.4992

Quadrangle: WI B-1

Longitude: 150.1072

Location description and accuracy:

Buckeye Gulch is a short, east-flowing tributary to the lower Hammond River; it is approximately 2 miles northeast of Smith Creek Dome. The mine is just above the mouth of Buckeye Gulch. Placer mining has occurred from near the mouth of the gulch, upstream for a distance of about 2,000 feet. The location is accurate.

\section{Commodities:}

Main: $\mathrm{Au}$

Other:

Ore minerals: Gold

\section{Gangue minerals:}

Geologic description:

The modern bed of Buckeye Gulch was said to have been mined in the early 1900's for about 2,000 feet above its mouth (Reed, 1938). The gold near the mouth of the gulch probably was derived from bench gravels of the Hammond River (Dillon, 1982).

\section{Alteration:}

Age of mineralization:

Quaternary.

Deposit model:

Placer Au (Cox and Singer, 1986; model 39a)

Deposit model number (After Cox and Singer, 1986 or Bliss, 1992):

$39 \mathrm{a}$

Production Status: Yes; small

Site Status: Inactive

\section{Workings/exploration:}

About 2,000 feet of Buckeye Gulch above its mouth was mined in the 1900's. A high channel of the Hammond River, which was exposed in Buckeye Gulch just above its mouth was being explored in 1937 (Reed, 1938).

Production notes:

Probably some production.

\section{Reserves:}


Additional comments:

References:

Maddren, 1913; Reed, 1938; Heiner and Wolff, 1968; Dillon, 1982.

Primary reference: Reed, 1938

Reporter(s): J.M. Britton (Anchorage)

Last report date: $8 / 9 / 2002$ 


\section{Site name(s): Nolan Creek (includes Mary's Bench and Swede Channel)}

Site type: Mine

ARDF no.: WI101

Latitude: 67.4754

Quadrangle: WI B-1

Longitude: 150.2307

Location description and accuracy:

Nolan Creek is a south-southwesterly-flowing tributary of Wiseman Creek; its mouth is about 5 miles northwest of Wiseman. The coordinates are at a cabin shown on the 1:63,360-scale topographic map on the west bank of Nolan Creek just above the mouth of Smith Creek. The placer deposits extends approximately 1 mile below and 1.75 miles above the cabin. The Mary's Bench and Swede Channel placers are bench deposits of Nolan Creek just east of Nolan Creek between Smith and Archibald Creeks. The location is accurate.

\section{Commodities:}

Main: $\mathrm{Au}$

Other:

Ore minerals: Gold

\section{Gangue minerals:}

\section{Geologic description:}

Gold placers in Nolan Creek valley are in shallow gravels of the modern stream, in bench gravels, and in frozen gravels in a deep channel. The gravels of the deep channel have been the most productive by far.

The present channel in Nolan Creek was mined just below the mouth of Fay Creek (near the Discovery claim) from 1903 to 1905. This channel together with shallow gravels on Smith and Fay Creeks produced a considerable amount of gold. The shallow gravels on Nolan Creek were about 3.5 feet thick and lay on false bedrock in the valley fill. Reed (1938) suggested that the gold in this placer was derived from erosion of gold-bearing gravels in Fay Creek. Recent information from the Internet page website of Silverado Gold Mines, the current property owner, (http://www.silverado.com) indicates that shallow placer deposits also occur on upper Nolan Creek for about 0.5 mile above Fay Creek.

The bench deposits on Nolan Creek generally are between the mouth of Fay Creek to just below the mouth of Smith Creek. The configuration of several of these bench deposits suggests that at least some of them may be derived from the eastern tributaries to Nolan Creek. Most are located along the east side of Nolan Creek and 20 to more than 200 feet above the modern stream. The gravel in these deposits is frozen and coarse grained but contains few boulders. The gold is also coarse; it includes small nuggets and a few large nuggets. The gold fineness varies from 885 to 962 . According to Reed (1938) these deposits varied in value from $\$ 0.25$ to $\$ 4.20$ per square foot of bedrock (gold at $\$ 35$ per ounce).

The most productive portion of the Nolan Creek placers has been the deep channel. This extends for about 2 miles along the Nolan Creek valley from near the mouth of Fay Creek to about 0.75 mile below the mouth of Smith Creek. At its upper end, the deep channel is about 20 feet below the surface; it gradually deepens to over 200 feet at its lower end. The average gradient of the deep channel is about 4.5 percent but there are a number of steeper gradients as the channel makes its way down valley. The gravel and overlying fill in Nolan Creek is frozen and waterworn and generally fairly fine, grained; however, large boulders commonly are scattered throughout the gravel. The gold in the deep channel lies directly on bedrock. It is rounded and waterworn and generally coarse grained; large nuggets are rare. Values, according to Reed (1938), range from $\$ 1.15$ to as much as $\$ 15$ per square foot of bedrock (gold at $\$ 35$ per ounce).

In addition to the principal deep channel, there are sections of other deep channels that have been pre- 
served at levels above the principal channel. Reed (1938) speculated that these remnants may have been bench deposits formed either when the deep-channel stream was active, or when an aggrading Nolan Creek deposited gold in channels cut in the valley walls as it meandered across the valley floor.

The rocks in the valley of Nolan Creek are predominantly black metasiltstone, phyllite, pelitic schist and black slate of the Middle to Upper Devonian, Beaucoup Formation (Eden, 2000).

Nolan Creek has been extensively mining and prospected beginning in 1903 and continuing until the present (2000). Most early mining was by underground drifting. Modern mining has been by open-pit operation in the summer and underground drift mining in frozen gravel in the winter. Reed (1938) noted that by 1937 the deep channel was considered mined out. However, press releases from Silverado Gold Mines (the current property owner) indicate that mining is continuing in the Nolan Creek valley, and that further exploration on the deep channel is planned.

\section{Alteration:}

Age of mineralization:

Quaternary.

Deposit model:

Placer Au (Cox and Singer, 1986; model 39a)

Deposit model number (After Cox and Singer, 1986 or Bliss, 1992):

$39 \mathrm{a}$

Production Status: Yes; small

Site Status: Active

Workings/exploration:

Nolan Creek has been extensively mining and prospected beginning in 1903 and continuing until the present (2000). Most early mining was by underground drifting. Modern mining has been by open-pit operation in the summer and underground drift mining in frozen gravel in the winter. Reed (1938) noted that by 1937 the deep channel was considered mined out. However, press releases from Silverado Gold Mines (the current property owner) indicate that mining is continuing in the Nolan Creek valley, and that further exploration on the deep channel is planned.

\section{Production notes:}

Maddren (1913) reports gold production from Nolan Creek between 1904 and 1909 was \$765,000 (approximately 40,300 ounces). Eden (2000) reports that a total of 135,437.70 ounces of gold was produced from Nolan Creek between 1904 and 1999. A press release dated October 27, 1999 from Silverado Gold Mines (the current property owner) indicated that a total of 734 ounces of gold were recovered during mining operations in the summer of 1999. A press release from Silverado Gold Mines on Aug. 24, 2000 indicated that the company was actively mining on Nolan Creek.

\section{Reserves:}

A number of reserve figures for the Nolan Property (which includes Nolan Placer, Nolan Lode, Thompson's Pup, Dionne (Mary's Bench) and Smith Creek) are given on the website of the Silverado Gold Mines Ltd., the current property owner (http://www.silverado.com/) . A press release dated February 16, 2000 posted on the website indicated a gold reserve of 145,000 oz. of proven, probable, and drill-indicated reserves for the Nolan Gold Property. This figure is presumed to represent a total resource for the entire property. On the website, Silverado has also described a probable and possible gold resource for the Nolan Placer of 114,760 ounces. Although it is unclear from the information on the website what portion of the overall Nolan property this reserve figure represents, the information implies that it is for the Nolan deep channel.

Additional comments: 
Pleistocene fossils occur in the deep channel and overlying muck.

\section{References:}

Schrader, 1904; Brooks, 1908; Brooks, 1909; Maddren, 1910; Brooks, 1911; Brooks, 1912; Brooks, 1913; Maddren, 1913; Brooks, 1915; Brooks, 1916; Smith, 1917 (BMB 142); Smith, 1917 (BMB 153); Brooks, 1918; Brooks and Martin, 1921; Brooks, 1922; Brooks, 1923; Brooks and Capps, 1924; Wimmler, 1925; Smith, 1929; Smith, 1930 (B810) ; Smith, 1930 (B813); Smith, 1932; Smith, 1933 (B836); Smith, 1933 (B844A); Smith, 1934 (B857A); Smith, 1934 (B864A); Smith, 1936; Smith, 1937; Reed, 1938; Smith, 1938; Smith, 1939 (B910A); Smith, 1939 (B917A); Smith, 1941; Smith, 1942; Brosge and Reiser, 1960; Heiner and Wolff, 1968; Brosge and Reiser, 1972; Cobb, 1972 (MF-469); Cobb, 1973 (B1374); Mulligan, 1974; Carnes, 1976; Cobb, 1976 (OF76-340); Cobb, 1981 (OF81-732); Bundtzen and others, 1982; Dillon, 1982; Eakins and others, 1983; Armstrong, 1985; Bundtzen and others, 1984; Eakins and others, 1985; Bundtzen and others, 1986; Bundtzen and others, 1987; Maas, 1987; Bliss and others, 1988; Bundtzen and others, 1988; Green and others, 1989; Bundtzen and others, 1990; Bundtzen and others, 1992; Swainbank and others, 1993; Bundtzen and others, 1994; Swainbank and others, 1995; Bundtzen and others, 1996; Swainbank and others, 1997; Swainbank and others, 1998; Kurtak and others, 1999; Szumigala and Swainbank, 1999; Eden, 2000; Swainbank and others, 2000; Kurtak and others, 2002.

Primary reference: Reed, 1938

Reporter(s): J.M. Britton (Anchorage)

Last report date: $8 / 9 / 2002$ 


\section{Site name(s): Swift Creek; Swift Gulch}

Site type: Mine

ARDF no.: WI102

Latitude: 67.4902

Quadrangle: WI B-1

Longitude: 150.1115

Location description and accuracy:

Swift Creek is a northeast-flowing tributary of the Hammond River that begins on the northeast flank of Smith Creek Dome. The placer deposits extend from the mouth of Swift Creek about a mile upstream; the workings continue a short distance up a small, left-limit gully that joins Swift Creek about 0.8 mile above its mouth. The location is accurate.

\section{Commodities:}

Main: $\mathrm{Au}$

Other:

Ore minerals: Gold

\section{Gangue minerals:}

Geologic description:

Gold was produced from Swift Creek as early as 1901(Schrader, 1904). The richest gold placer deposits were near the mouth, although the mines produced only wages and small amounts of coarse gold (Maddren, 1913). The modern stream bed has been mined as well as a high channel that coalesced with an eroded high channel of the Hammond River. Some of the gold had a white coating similar to that found on the gold from Smith Creek (WI116). Mosier and Lewis (1986) report that the gold was 880 fine from the high channel and 924 fine from the modern channel. Of three panned-concentrate samples from Swift Creek, only one, near the mouth, showed any visible gold (Kurtak and others, 1999). The rocks in the area are predominantly chlorite-mica schist, quartz-mica schist, and phyllite (Eden, 2000). Swift Creek drains mineralized areas on Smith Creek Dome (WI107, WI110, and WI127).

\section{Alteration:}

Age of mineralization:

Quaternary.

Deposit model:

Placer Au (Cox and Singer, 1986; model 39a)

Deposit model number (After Cox and Singer, 1986 or Bliss, 1992): $39 \mathrm{a}$

Production Status: Yes

Site Status: Inactive

Workings/exploration:

Swift Creek was mined by hand methods between 1901 and 1927. Gold production in later years may have been included with reports from the Hammond River (WI103). 


\section{Production notes:}

Maddren (1913) reports gold production of \$7,200 (approximately 380 ounces) between 1902 and 1909. Reed (1938) noted that the high channel had been worked out several years before his visit.

\section{Reserves:}

\section{Additional comments:}

\section{References:}

Schrader, 1904; Brooks, 1908; Maddren, 1910; Brooks, 1913; Maddren, 1913; Wimmler, 1925; Smith, 1930 (B810); Reed, 1938; Heiner and Wolff, 1968; Cobb, 1972 (MF-469); Cobb, 1973 (B1374); Mulligan, 1974; Cobb, 1976 (OF76-340); Grybeck, 1977; Dillon, 1982; Maas, 1987; Bliss and others, 1988; Kurtak and others, 1999; Eden, 2000; Kurtak and others, 2002.

Primary reference: Reed, 1999

Reporter(s): J.M. Britton (Anchorage)

Last report date: $8 / 9 / 2002$ 


\section{Site name(s): Hammond River; Hammond Creek}

Site type: Mine

ARDF no.: WI103

Latitude: 67.4874

Quadrangle: WI B-1

Longitude: 150.0477

Location description and accuracy:

The Hammond River is a large, northern tributary of the Middle Fork, Koyukuk River. It begins near Alhamblar Mountain, nearly 35 miles north of its junction with the Middle Fork. The mouth of the Hammond River is located approximately 4 miles northeast of Wiseman and 3 miles east of Midnight Dome. Gold has been produced from the Hammond River for a distance of about 13 miles above its mouth, but most mining has been within 3 miles of the mouth. The 13 miles of productive ground extends from its mouth to the mouth of Canyon Creek. The coordinates are about the center of the more productive ground, near the Discovery claim.

\section{Commodities:}

Main: $\mathrm{Au}$

Other:

Ore minerals: Galena, gold, pyrite

Gangue minerals:

\section{Geologic description:}

Gold was discovered on the Hammond River about 1900 (Maddren, 1913). The gold is mainly along the lower 13 miles of the river, although most mining has occurred within 3 miles of its mouth. The gold is in the modern channel, a deep channel, and a high channel. Most of the gold has come from the deep channel.

There has been intermittent mining of the gravels in the modern channel, mostly prior to 1910. This mining was principally in areas where the river has cut to bedrock from just below Buckeye Gulch to above the mouth of the Hammond River. According to Maddren (1913), this mining in the modern channel produced about $\$ 8,000$ to $\$ 10,000$ in gold (gold at $\$ 20.67$ per ounce) by 1913 . Gravel in the deep channel have been mined from near the mouth of Buckeye Gulch to about a mile or so above the mouth of the Hammond River. The lower end of the deep channel extends into the valley of the Middle Fork, Koyukuk River, but is truncated in valley, presumably by glacial scouring.

The deep channel is approximately 30 feet wide and lies more than 115 feet below the modern river level at its lower end, rising to about 35 feet below the modern channel near its upper end. The gravels of the deep channel were said to become richer downstream. The gold in the deep channel occurs directly on bedrock; it is coarse grained, rounded, and waterworn. Galena and pyrite are locally associated with the gold. The deep channel, except for a few areas overlooked by the early miners, was thought to be mined out by 1937 (Reed, 1938). Workings in one of these overlooked spots in 1936 and 1937 found a section 8-10 thick of paying gravel. The channel was 35 feet wide and the depth to bedrock was 115 feet. The gravel consisted of small boulders and large cobbles, separated by sand and fine gravel. The gravel was frozen to bedrock (although this was not always the case at other locations along the deep channel) and the bedrock was described as hard schist (Reed, 1938). The gold included many nuggets, was waterworn, and had a fineness of 961. According to Reed (1938), the ground was valued at about $\$ 1.46$ per square foot of bedrock (gold at $\$ 35$ per ounce).

Gold also occurs in sections of a high channel preserved along the lower Hammond River. These sections appear to be 40-50 feet above the modern river bed and were first encountered in locations where the high channel is cut by tributary streams such as at Buckeye Gulch (WI100). Little additional information is avail- 
able about these bench deposits.

Much coarse gold has been produced from the Hammond River, including several nuggets valued at $\$ 800$ to $\$ 1100$ (gold at $\$ 20.67$ per ounce.) and a 137 ounce nugget (Maddren, 1913; Dillon, 1982). Mosier and Lewis (1986) reported that gold in 14 samples from Hammond River varies from from 845 to 929 fine with a median fineness of 900 .

See also: Slisco Bench (WI129).

\section{Alteration:}

Age of mineralization:

Quaternary.

Deposit model:

Placer Au (Cox and Singer, 1986; model 39a)

\section{Deposit model number (After Cox and Singer, 1986 or Bliss, 1992):} $39 \mathrm{a}$

Production Status: Yes; small

Site Status: Active?

Workings/exploration:

Workings included extensive drift mining on the deep channel, beginning around 1913 and continuing until around 1950. Drift mining of the deep channel was often impeded by water problems in thawed gravels. There was limited mining of the modern stream bed, generally by hand methods, in the early 1900's. Some mining took place on preserved sections of a high channel early 1900's. Mining has continued along the Hammond River intermittently through at least the 1990's. This work included opencut mining near Wiseman in 1993 (Bundtzen and others, 1994) and open-pit mining as late as 2000 (Szumigala and others, 2001).

\section{Production notes:}

The total placer gold production figures for the Hammond River are uncertain, but most reports agree that it has been substantial. Bliss and others (1988) indicate that total production may have been in the range of 1.2 to 1.8 tonnes of gold (although these figures likely included production from tributaries, including Gold Bottom Gulch (WI104), Buckeye Gulch (WI100), Swift Creek (WI130), and Steep Creek). Eden (2000) reported that only 17,255.90 ounces of gold has been produced from the Hammond River between 1904 and 1999.

\section{Reserves:}

\section{Additional comments:}

\section{References:}

Brooks, 1904; Schrader, 1904; Maddren, 1910; Brooks, 1912; Brooks, 1913; Maddren, 1913; Brooks, 1914; Brooks, 1915; Brooks, 1916; Smith, 1917 (BMB 142); Smith, 1917 (BMB 153); Brooks, 1918; Brooks and Capps, 1924; Wimmler, 1925; Moffit, 1927; Smith, 1929; Wimmler, 1929; Smith, 1930 (B810); Smith, 1930 (B813); Smith, 1933 (B844A); Smith, 1934 (B857A); Smith, 1934 (B864A); Smith, 1936; Smith, 1937; Reed, 1938; Smith, 1938; Smith, 1941; Smith, 1942; Brosge and Reiser, 1960; Heiner and Wolff, 1968; Brosge and Reiser, 1972; Cobb, 1972 (MF-469); Cobb, 1973 (B1374); Mulligan, 1974; Cobb, 1976 (OF76-340); Dillon, 1982; Mosier and Lewis, 1986; Maas, 1987; Bliss and others, 1988; Bundtzen and others, 1988; Green and others, 1989; Bundtzen and others, 1990; Swainbank and others, 1991; Bundtzen and others, 1994; Swainbank and others, 1998; Kurtak and others, 1999; Eden, 2000; Szumigala and others, 2001; Kurtak and others, 2002. 
Primary reference: Reed, 1938

Reporter(s): J.M. Britton (Anchorage)

Last report date: $8 / 9 / 2002$ 


\section{Site name(s): Gold Bottom Gulch; Gold Bottom Creek}

Site type: Mine

ARDF no.: WI104

Latitude: 67.4844

Quadrangle: WI B-1

Longitude: 150.0798

Location description and accuracy:

Gold Bottom Gulch is a short, steep, south tributary to the lower Hammond River. It drains the northeast flank of Midnight Dome between Lofty Gulch and Steep Gulch. This mine is about 5 miles north-northeast of Wiseman. Most placer mining on Gold Bottom Gulch was near the mouth but it extended approximately 0.5 mile upstream. The location is accurate.

\section{Commodities:}

Main: $\mathrm{Au}$

Other:

Ore minerals: Gold

\section{Gangue minerals:}

Geologic description:

Maddren (1913) reported that 600 to 700 feet of the modern channel near the mouth of Gold Bottom Gulch was mined; a \$400 nugget was recovered in 1904 (gold at \$20.67 per ounce). These shallow gravels were mined out in the early 1900's. Reed (1938) noted mining of a high channel and a deep channel in 1937 near the mouth of the creek. Bedrock had not yet been reached in the deep channel and the only production was of gold scattered through the gravel. There were two types of gold in the deep channel (Reed, 1938). Most was a coarse-grained, rounded gold similar to that found in the Hammond River deep channel; this was accompanied by lesser amounts of very fine and flaky gold. The gravel in the deep channel is not frozen. The high channel is on the west side of Gold Bottom Gulch, about 50 feet above the bottom of the cut in which the deep channel was being mined in 1937 (Reed, 1938). The high channel was prospected in 1937, but not mined. From 1978 to the present (2000), mining has been by dozer, excavator and washing plant; production figures are not available. Dillon (1982) speculates that the gold in the lower parts of tributaries of the Hammond River, such as Gold Bottom Gulch, is mostly derived from bench gravels of the Hammond River.

\section{Alteration:}

Age of mineralization:

Quaternary.

\section{Deposit model:}

Placer Au (Cox and Singer, 1986; model 39a)

Deposit model number (After Cox and Singer, 1986 or Bliss, 1992): $39 \mathrm{a}$

Production Status: Yes

Site Status: Active 


\section{Workings/exploration:}

The modern channel near the mouth of Gold Bottom Gulch was mined out within a few years after 1900. In 1937, the deep channel was mined by ground sluicing and shoveling into sluice boxes, and there was prospecting of a high channel. From 1978 to the present (2000), mining has been by dozer, excavator, and washing plant; production figures are not available.

\section{Production notes:}

Maddren (1913) reported gold production totaling \$10,000 from 1900 to 1909 (gold at \$20/ounce). From 1978 to the present (2000), mining has been by dozer, excavator, and washing plant; production figures are not available.

\section{Reserves:}

\section{Additional comments:}

\section{References:}

Maddren, 1913; Reed, 1938; Heiner and Wolff, 1968; Dillon, 1982; Bliss and others, 1988; Eden, 2000.

Primary reference: Reed, 1938

Reporter(s): J.M. Britton (Anchorage)

Last report date: $8 / 9 / 2002$ 


\section{Site name(s): Clara Creek; Clara Gulch}

Site type: Mine

ARDF no.: WI105

Latitude: 67.2193

Quadrangle: WI B-1

Longitude: 150.0338

Location description and accuracy:

Clara Creek is a westward-flowing tributary to the Middle Fork, Koyukuk River; its mouth is about 1 mile north of Coldfoot. The location of mining on the creek is not accurately described, but it probably occurred over at least a mile of the creek near the junction of Clara Creek and the Middle Fork.

\section{Commodities:}

Main: $\mathrm{Au}$

Other:

Ore minerals: Gold

Gangue minerals:

Geologic description:

Gold was discovered on Clara Creek in 1900. Mining in 1900 and 1901 produced \$3,000 in gold (about 150 ounces), including an 18 ounce nugget (Maddren, 1913; Schrader, 1904). Reed (1938) reported no evidence of mining on the creek since the early 1900's, although Smith (1936) reported mining in 1934.

Alteration:

Age of mineralization:

Quaternary.

Deposit model:

Placer Au (Cox and Singer, 1986; model 39a)

Deposit model number (After Cox and Singer, 1986 or Bliss, 1992):

$39 \mathrm{a}$

Production Status: Yes

Site Status: Active?

Workings/exploration:

Some mining prior to 1934 and considerable prospecting. There was some recreational suction dredging in the 1990's (Kurtak and others, 2002).

Production notes:

Mining in 1900-1901 produced \$3,000 worth of gold (about 150 ounces), including an 18 ounce nugget.

Reserves:

Additional comments: 


\section{References:}

Schrader, 1900; Schrader, 1904; Maddren, 1910; Maddren, 1913; Smith, 1936; Reed, 1938; Heiner and Wolff, 1968; Cobb, 1972 (MF-469); Mulligan, 1974; Cobb, 1976 (OF76-340); Maas, 1987; Bliss and others, 1988; Bundtzen and others, 1990.

Primary reference: Maddren, 1913

Reporter(s): J.M. Britton (Anchorage)

Last report date: $8 / 9 / 2002$ 


\section{Site name(s): Ferguson}

Site type: Prospect

ARDF no.: WI106

Latitude: 67.4367

Quadrangle: WI B-1

Longitude: 150.1627

Location description and accuracy:

This prospect is located just east of the ridge line of Midnight Dome at the head of Union Gulch. The prospect is at an elevation of about 3,500 feet, about 0.7 mile southeast of the center of section 35 , T. $31 \mathrm{~N}$., R 12 W., of the Fairbanks Meridian. The location is accurate.

\section{Commodities:}

Main: $\mathrm{Au}, \mathrm{Sb}$

Other: Ag

Ore minerals: Gold, stibnite

Gangue minerals: Quartz

\section{Geologic description:}

This deposit was described by Ebbley and Wright (1948) as prospect pits that expose a 6-inch quartz vein containing kernels of stibnite in an earthy yellow matrix of antimony oxides. Samples of vein material contain 0.03 to $0.04 \mathrm{ppm}$ gold, up to $0.15 \mathrm{ppm}$ silver, more than $1 \%$ antimony. A sample of bedrock contains 0.05 ppm gold, 0.1 ppm silver, and 0.03\% antimony. (Brosge and Reiser, 1970). Samples of the quartzstibnite vein collected by Dillon (1982) contain up to $14 \mathrm{ppm}$ Au. A sample of fine- to coarse-grained, crystalline stibnite from dump material assays 62\% Sb (Mulligan, 1974). Kurtak and others (1999) analyzed two samples in the late 1990's. One sample, described as massive stibnite and a yellow alteration mineral contains 14 ppb gold and 33\% antimony. The other, a quartz veinlet with more than $1 \%$ pyrite, contains 37 ppb gold and 25 ppm antimony. The rocks in the area are Middle or Upper Devonian(?) calcareous, chloritic wacke (Dillon and others, 1986).

\section{Alteration:}

Oxidation of stibnite to yellow Sb oxides.

Age of mineralization:

Deposit model:

Simple Sb deposit (Cox and Singer, 1986; model 27d)

Deposit model number (After Cox and Singer, 1986 or Bliss, 1992): $27 d$

Production Status: None

Site Status: Inactive

Workings/exploration:

There are at least two prospect pits. 
Production notes:

Reserves:

Additional comments:

See also: Jones and Boyle (WI114), and Wannemaker and Wortman (WI115).

\section{References:}

Ebbley and Wright, 1948; Berg and Cobb, 1967; Heiner and Wolff, 1968; Brosge and Reiser, 1970; Brosge and Reiser, 1972; Cobb, 1972 (MF-469); Mulligan, 1974; Cobb, 1976 (OF76-340); Grybeck, 1977; Dillon and others, 1986; Dillon, 1982; Maas, 1987; Bliss and others, 1988; Kurtak and others, 1999; Eden, 2000.

Primary reference: Ebbley and Wright, 1948

Reporter(s): J.M. Britton (Anchorage)

Last report date: $8 / 9 / 2002$ 


\section{Site name(s): Palisades}

Site type: Occurrence

ARDF no.: WI107

Latitude: 67.4895

Quadrangle: WI B-1

Longitude: 150.1568

Location description and accuracy:

This occurrence is at an elevation of about 3,250 feet on the divide between Fay creek and Swift Creek. It is just north of the center of the southern boundary of section 23, T. 31 N., R. 12 W., of the Fairbanks Meridian. The location is accurate.

\section{Commodities:}

Main: $\mathrm{Ag}, \mathrm{Au}$

Other: $\mathrm{As}, \mathrm{Sb}$

Ore minerals: Arsenopyrite, gold, pyrite

Gangue minerals: Limonite, quartz

\section{Geologic description:}

Brosge and Reiser (1972) collected a series of soil and rock samples, and quartz veins for approximately 0.5 mile across this area. The quartz veins contain elevated gold, silver, antimony, and arsenic. One of the samples, described as a thin quartz vein contains 5.8 and 0.97 ppm gold in replicate analyses. Eden (2000) reported quartz veins with arsenopyrite and pyrite exposed in a trench in the same general area. Several trench and outcrop samples of oxidized, pyrite- or arsenopyrite-bearing quartz contained up to 90 ppb gold and 4,760 arsenic. The veins strike east-west and dip steeply. The pyrite and arsenopyrite form euhedral crystals in open spaces. The rocks in the area are Upper Devonian quartz-mica schist, phyllite, and micaceous schist (Eden, 2000).

\section{Alteration:}

Iron-oxide alteration.

Age of mineralization:

Deposit model:

Low-sulfide Au-quartz vein (Cox and Singer, 1986; model 36a)

Deposit model number (After Cox and Singer, 1986 or Bliss, 1992): $36 \mathrm{a}$

Production Status: None

Site Status: Probably inactive

\section{Workings/exploration:}

Surface sampling and trenching.

Production notes: 


\section{Reserves:}

Additional comments:

See also: Smith Creek Dome (WI110).

\section{References:}

Brosge and Reiser, 1972; Cobb, 1972 (MF-469); Cobb, 1976 (OF76-340); Dillon, 1982; Kurtak and others, 1999; Eden, 2000.

Primary reference: Eden, 2000

Reporter(s): J.M. Britton (Anchorage)

Last report date: $8 / 9 / 2002$ 


\section{Site name(s): Wiseman Creek}

Site type: Prospects

ARDF no.: WI108

Latitude: 67.4212

Quadrangle: WI B-1

Longitude: 150.0630

Location description and accuracy:

Wiseman Creek is a tributary to the Middle Fork, Koyukuk River. It flows north from the north flank of Emma Dome, swings in a large arc to the east, and then flows southeast to enter the Middle Fork at the town of Wiseman. Placer prospecting on Wiseman Creek has generally focused on the 4 or 5 miles of Wiseman Creek between Nolan Creek and the Middle Fork, Koyukuk. The prospects are somewhat arbitrarily placed about 2.8 miles southeast of the junction of Nolan and Wiseman Creeks at the prospect symbols on the Wiseman B-1 topographic map.

\section{Commodities:}

Main: $\mathrm{Au}$

Other:

Ore minerals: Gold

\section{Gangue minerals:}

\section{Geologic description:}

Gold prospecting has been concentrated in the area between the mouth of Nolan Creek and the Middle Fork Koyukuk River. Prospecting is severely hampered by thick glacial deposits in the valley. Only one shaft, located about a mile below Nolan Creek, is known to have reached bedrock. This shaft was 260 feet deep and encountered only colors of gold in 30 feet of washed gravel in the lower 40 feet of the shaft. A second shaft was sunk to a depth of 335 feet and a pipe driven another 30 feet without reaching bedrock. In the 1920's an attempt was made to find a deep channel under the glacial deposits by making two open cuts along the edge of the valley about 1.5 mile northwest of the town of Wiseman. These cuts found only fine, flour gold with values estimated to be $\$ 0.06$ to $\$ 0.10$ per cubic yard of gravel (gold at $\$ 20.67$ per ounce) (Reed, 1938).

Also see Nolan Creek (WI101).

\section{Alteration:}

Age of mineralization:

Quaternary.

\section{Deposit model:}

Placer Au (Cox and Singer, 1986; model 39a)

Deposit model number (After Cox and Singer, 1986 or Bliss, 1992): $39 \mathrm{a}$

Production Status: None

Site Status: Inactive 
Workings/exploration:

Wiseman Creek was explored by deep prospect shafts in 1908 and 1909 (Maddren, 1913) and by open cuts from 1924 to 1929 (Reed, 1938). There has been little or no mining or gold production. Over the years, placer claims have been staked along the length and width of Wiseman Creek valley but the creek has not proven to contain any significant concentrations of gold.

Production notes:

Wiseman Creek was prospected from 1909 to at least 1924 but there is little evidence of production (Maddren, 1913; Reed, 1938).

\section{Reserves:}

\section{Additional comments:}

\section{References:}

Schrader, 1900; Brooks, 1905; Maddren, 1910; Maddren, 1913; Smith, 1932; Smith, 1933 (B836); Reed, 1938; Smith, 1939 (B910A); Smith, 1939 (B917A); Heiner and Wolff, 1968; Cobb, 1972 (MF-469); Cobb, 1976 (OF76-340); Cobb, 1981 (OF81-732); Maas, 1987.

Primary reference: Reed, 1938

Reporter(s): J.M. Britton (Anchorage)

Last report date: $8 / 9 / 2002$ 


\section{Site name(s): Roches Moutonnees}

Site type: Occurrence

ARDF no.: WI109

Latitude: 67.3470

Quadrangle: WI B-1

Longitude: 150.1808

Location description and accuracy:

This occurrence is on the west side of the Middle Fork, Koyukuk River about 0.5 mile northwest of the mouth of Moose Creek. It is at an elevation of about 1,530 feet, 0.1 mile south of the center of section 35 , T. 30 N., R. 12 W., of the Fairbanks Meridian. The name, Roches Moutonnees, is derived from the rounded hummock outcrops in the area, which are said to form a distinctive local feature. The location is accurate within one-half mile.

\section{Commodities:}

Main: $\mathrm{Cu}$

Other: $\mathrm{Zn}$

Ore minerals: Bornite

Gangue minerals: Quartz

Geologic description:

This occurrence consists of quartz veinlets in dolomite and limestone (Mulligan, 1974). Analysis of the veinlets show trace amounts of copper and zinc, but the only visible sulfide in freshly broken quartz was a small bleb of bornite. The rocks in the area are Proterozoic or lower Paleozoic(?), calcareous schist, and local marble (Dillon and others, 1986).

\section{Alteration:}

Age of mineralization:

Deposit model:

Deposit model number (After Cox and Singer, 1986 or Bliss, 1992):

Production Status: None

Site Status: Inactive

Workings/exploration:

Only surface sampling.

Production notes:

Reserves:

Additional comments:

References: 
Mulligan, 1974; Dillon and others, 1986; Bliss and others, 1988.

Primary reference: Mulligan, 1974

Reporter(s): J.M. Britton (Anchorage)

Last report date: $8 / 9 / 2002$ 


\section{Site name(s): Unnamed (on Smith Creek Dome)}

Site type: Prospect

ARDF no.: WI110

Latitude: 67.4852

Quadrangle: WI B-1

Longitude: 150.1554

Location description and accuracy:

This prospect is at an elevation of about 3,150 feet in a saddle approximately 0.7 mile northeast of the summit of Smith Creek Dome. The location is accurate.

Commodities:

Main: $\mathrm{Au}, \mathrm{Sb}$

Other:

Ore minerals: Cervantite, gold, kermesite, stibiconite, stibnite

Gangue minerals: Quartz

\section{Geologic description:}

The prospect consists of stibnite and various alteration products of stibnite (including cervantite, kermesite, and stibiconite) in a 6-inch-wide vein exposed in an old trench. The vein strikes N5E and dips 50E. Rock samples collected by Brosge and Reiser (1972) from this prospect contain up to 9.2 ppm gold. A sample collected in the late 1990's described as vein quartz with stibnite and a yellow alteration mineral contained only 436 ppb gold, 297 ppm arsenic and 28.09\% antimony (Kurtak and others, 1999; Eden, 2000). The rocks in the area are Upper Devonian, brown micaceous schist, with lesser phyllite and metasiltstone (Eden, 2000).

\section{Alteration:}

The stibnite is altered to secondary antimony minerals.

Age of mineralization:

\section{Deposit model:}

Simple Sb deposit (Cox and Singer, 1986; model 27d)

Deposit model number (After Cox and Singer, 1986 or Bliss, 1992): $27 \mathrm{~d}$

Production Status: No

Site Status: Inactive

Workings/exploration:

Vein exposed in a small prospect pit or trench.

Production notes:

Reserves: 
Additional comments:

See also Jones and Boyle (WI114) and Wannemaker and Wortman (WI115). Note that the this prospect is different from another unnamed occurrence (WI127) nearer the summit of Smith Creek Dome.

\section{References:}

Joesting, 1943; Ebbley and Wright, 1948; Brosge and Reiser, 1960; Brosge and Reiser, 1972; Berg and Cobb, 1967; Cobb, 1972 (MF-469); Mulligan, 1974; Cobb, 1976 (OF76-340); Cobb, 1981 (OF81-732);

Dillon, 1982; Maas, 1987; Bliss and others, 1988; Kurtak and others, 1999; Eden, 2000.

Primary reference: Bliss and others, 1988

Reporter(s): J.M. Britton (Anchorage)

Last report date: $8 / 9 / 2002$ 


\section{Site name(s): Sawyer Creek; Sawyer Gulch}

Site type: Prospects

ARDF no.: WI111

Latitude: 67.3216

Quadrangle: WI B-1

Longitude: 150.1988

Location description and accuracy:

Sawyer Creek is a east-flowing tributary to the Middle Fork, Koyukuk River; it joins the Middle Fork about 4.75 miles east-southeast of Emma Dome. The exact locations of placer prospects on Sawyer Creek are unknown and these prospects are arbitrarily placed about 0.5 mile west of the mouth of Sawyer Creek.

\section{Commodities:}

Main: $\mathrm{Au}$

Other:

Ore minerals: Gold

Gangue minerals:

Geologic description:

Sawyer Creek was prospected for gold in 1936 (Reed, 1938). There is no record of any mining before then. Mosier and Lewis (1986) collected and analyzed five samples of gold from Sawyer Creek. However, there are no reports of actual mining on the creek, probably due in part to numerous large boulders in the creek gravels.

\section{Alteration:}

Age of mineralization:

Quaternary.

Deposit model:

Placer Au (Cox and Singer, 1986; model 39a)

Deposit model number (After Cox and Singer, 1986 or Bliss, 1992):

$39 \mathrm{a}$

Production Status: None

Site Status: Inactive

\section{Workings/exploration:}

Sawyer Creek was prospected for gold 1936 (Reed, 1938). There is no record of any mining before then.

Production notes:

Reserves:

Additional comments:

Also see Emma Creek (WI118). 


\section{References:}

Maddren, 1913; Reed, 1938; Heiner and Wolff, 1968; Cobb, 1972 (MF-469); Mulligan, 1974; Cobb, 1976 (OF76-340); Mosier and Lewis, 1986; Maas, 1987; Bliss and others, 1988.

Primary reference: Maddren, 1913

Reporter(s): J.M. Britton (Anchorage)

Last report date: $8 / 9 / 2002$ 


\section{Site name(s): Fay Creek; Fay Gulch; Faye Creek}

Site type: Mine

ARDF no.: WI112

Latitude: 67.4898

Quadrangle: WI B-1

Longitude: 150.1952

Location description and accuracy:

Fay Creek originates on the north side of Smith Creek Dome and flows westward a little more than 1 mile to Nolan Creek. Placer mining apparently extended from near the mouth of Fay Creek more than 4,000 feet upstream. The coordinates are just upstream from its mouth. The location is accurate.

\section{Commodities:}

Main: $\mathrm{Au}$

Other:

Ore minerals: Gold

Gangue minerals: Quartz

\section{Geologic description:}

Placer gold in Fay Creek occurs in the modern channel, in a deep channel, and in a high channel. The discovery in 1901 of gold in the shallow gravels near the mouth of the modern channel of Fay Creek sparked the initial interest in the Nolan Creek valley. These shallow gravels were first mined beginning in 1903 but were exhausted within a few years.

Gold in portions of a high channel along the north side of Fay Creek was mined prior to 1930. These highchannel placers begin about 1000 feet upstream from the mouth of the creek and are about 275 higher in elevation (Reed, 1938). A gold-bearing deep channel near the mouth of the creek, which in fact was a deep channel of Nolan Creek, was mined out in the early 1900's. This deep channel was about 20 feet below the surface.

Maddren (1913) noted that the placer gold in Fay Creek appeared not to have moved very far from its bedrock source as it generally occurs in rough and angular grains attached to quartz. There are reports of lode gold occurrences nearby on Smith Creek Dome (WI110 \& WI127), near the head of Fay Creek, and as well on on Thompson Pup (WI128), a tributary of Fay Creek (Brosge and Reiser, 1972). A sample of gold from Fay Creek is 842 fine, and contains 16\% silver, 94 ppm copper, 16 ppm lead, and $0.625 \%$ mercury (Mosier and Lewis, 1986).

The modern and deep channels of Fay Creek were mined in the early 1900's, but there is no record of the mining methods. Sections of the high channel were mined in the early 1900's and the high channel was being prospected in 1929 (Reed, 1938). Brosge and Reiser (1960) noted probable post-World War II mining activity and Dillon (1982) noted reports of recent mining activity. Fay Creek was the first creek in the Nolan Creek valley to have been mined. Reed (1938) indicated that mining began in 1901, whereas Maddren (1913) reported that it began in 1903. According to Maddren (1913) Fay Creek produced about $\$ 30,000$ of gold (about 1,500 ounces) between 1900 and 1909. Eden (2000) reports that a total of 1865.41 ounces of gold were produced from Fay Creek between 1904 and 1999. The modern stream channel and the deep channel were considered to have been mined out by 1937.

\section{Alteration:}

Age of mineralization:

Quaternary. 


\section{Deposit model: \\ Placer Au (Cox and Singer, 1986; model 39a) \\ Deposit model number (After Cox and Singer, 1986 or Bliss, 1992): \\ $39 a$}

Production Status: Yes

Site Status: Undetermined

Workings/exploration:

The modern and deep channels of Fay Creek were mined in the early 1900's, but there is no record of the mining methods. Sections of the high channel were mined in the early 1900's and the high channel was being prospected in 1929 (Reed, 1938). Brosge and Reiser (1960) noted probable post-World War II mining activity and Dillon (1982) noted reports of recent mining activity.

\section{Production notes:}

Fay Creek was the first creek in the Nolan Creek valley to have been mined. Reed (1938) indicated that mining began in 1901, whereas Maddren (1913) reported that it began in 1903. According to Maddren (1913) Fay Creek produced about $\$ 30,000$ of gold (about 1500 ounces) between 1900 and 1909. Eden (2000) reports that a total of 1865.41 ounces of gold were produced from Fay Creek between 1904 and 1999. The modern stream channel and the deep channel were considered to have been mined out by 1937 .

\section{Reserves:}

Additional comments:

See also: Nolan Creek (WI101), an unnamed deposit on Smith Creek Dome (WI110), and Thompson Pup (WI124).

\section{References:}

Brooks, 1908; Maddren, 1910; Maddren, 1913; Wimmler, 1925; Reed, 1938; Brosge and Reiser, 1960; Heiner and Wolff, 1968; Cobb, 1972 (MF-469); Mulligan, 1974; Cobb, 1976 (OF76-340); Grybeck, 1977; Dillon, 1982; Mosier and Lewis, 1986; Bliss and others, 1988; Swainbank and others, 1997; Eden, 2000.

Primary reference: Reed, 1938

Reporter(s): J.M. Britton (Anchorage)

Last report date: $8 / 9 / 2002$ 


\section{Site name(s): Archibald Creek; Archibald Gulch}

Site type: Mine

ARDF no.: WI113

Latitude: 67.4823

Quadrangle: WI B-1

Longitude: 150.2081

Location description and accuracy:

Archibald Creek is a west-flowing tributary to Nolan Creek. Its mouth is about 1.75 miles above the mouth of Nolan Creek on Wiseman Creek. Most of the mining activity on Archibald Creek has been along the lower 0.5 mile of the creek; the coordinates are about at the center of mining. The location is accurate.

\section{Commodities:}

Main: $\mathrm{Au}$

Other: $\mathrm{Sb}(?)$

Ore minerals: Gold, stibnite(?)

\section{Gangue minerals:}

\section{Geologic description:}

Placer gold has been mined both from the modern channel and a deep channel on Archibald Creek. The modern channel was mined near the mouth of the creek in the early 1900's and was being mined about 3/8 mile upstream in 1937. The gravel in the modern channel is coarse and subangular; it contains many boulders. Five to twelve feet of frozen gravel, covered by 3 feet of muck and a foot of moss, overlie soft, schist bedrock. The gold is distributed throughout the gravel and occurs both as fine particles worn flat and smooth, and as coarse particles that are rough and porous. The average fineness of the gold is 905 and the value of the ground is about $\$ 0.44$ per square foot of bedrock (gold at \$35 per ounce) (Reed, 1938).

The deep channel which is 5 to to 14 feet wide is on the north side of the creek at a depth of about 25 feet near the mouth of the creek; it rises upstream to coalesce with the modern channel. Seven to nine feet of frozen, coarse, subangular gravel overlies bedrock described as alternating bands of black graphitic and yellow schist (Reed, 1938). The gravel is overlain by 16 to 18 feet of muck and a foot of moss. Unlike the modern channel, the deep channel is free of large boulders. The gold in the deep channel occurs both as coarse, worn and rounded particles, and as coarse, porous and unworn particles. Reed (1938) reports values of approximately $\$ 2.11$ per square foot of bedrock (gold at \$35 per ounce) and an average fineness of 904 .

A stibnite vein was reported during drift mining on Archibald Creek (Ebbley and Wright, 1948.

\section{Alteration:}

Age of mineralization:

Quaternary.

\section{Deposit model:}

Placer Au (Cox and Singer, 1986; model 39a)

Deposit model number (After Cox and Singer, 1986 or Bliss, 1992): $39 \mathrm{a}$

Production Status: Yes; small 
Site Status: Inactive

\section{Workings/exploration:}

The creek and bench placers have been mined by hand and hydraulic methods, and the deep channel by drifting. Mulligan (1974) reported hand mining in 1974.

\section{Production notes:}

Maddren (1913) reported \$6,000 of gold (about 300 ounces) was produced from 1900 to 1909 . Eden (2000) reports a total of 5429.90 ounces of gold were produced from Archibald Creek between 1904 and 1999.

Most of the production from Archibald Creek has been from the buried channels. Tri-Con Mining mined on Archibald Creek as late as 1991 (Bundtzen and others, 1992).

\section{Reserves:}

\section{Additional comments:}

See also Nolan Creek (WI101).

\section{References:}

Maddren, 1910; Maddren, 1913; Wimmler, 1925; Smith, 1930 (B810); Smith, 1934 (B864A); Smith, 1936; Smith, 1937; Reed, 1938; Smith, 1938; Smith 1939, (B910A); Smith, 1939 (B917A); Ebbley and Wright, 1948; Heiner and Wolff, 1968; Mulligan, 1974; Dillon, 1982; Eakins and others, 1983; Armstrong, 1985; Bundtzen and others, 1984; Eakins and others, 1985; Bundtzen and others, 1986; Mosier and Lewis, 1986; Bundtzen and others, 1988; Bundtzen and others, 1992; Swainbank and others, 1993; Eden, 2000.

Primary reference: Reed, 1938

Reporter(s): J.M. Britton (Anchorage)

Last report date: $8 / 9 / 2002$ 


\section{Site name(s): Jones \& Boyle}

Site type: Prospect

ARDF no.: WI114

Latitude: 67.4753

Quadrangle: WI B-1

Longitude: 150.2127

Location description and accuracy:

This prospect is on the north bank of lower Smith Creek, about 0.4 mile north-northeast of the center of section 33, T. 30 N., R. 12 W., of the Fairbanks Meridian. The prospect is about 0.1 mile south-southwest of the mine symbol on the Wiseman B-1 topographic map. The location is accurate.

\section{Commodities:}

Main: $\mathrm{Au}, \mathrm{Sb}$

Other:

Ore minerals: Gold, stibnite

Gangue minerals: Quartz

\section{Geologic description:}

This prospect consists of a series of quartz-stibnite veins, 1 to 40 feet apart, that were exposed during placer mining sometime prior to 1943. The veins apparently were still exposed in the old placer cuts as late as 1974. Ebbley and Wright (1948) describe six, parallel quartz-stibnite veins, 3-4 inches wide; the stibnite is concentrated in the central 1.5 to 2 inches of the veins. W. W. Patton Jr.'s, U. S. Geological Survey field notes in 1953 indicate that the veins are as wide as 1 foot and that their stibnite core is as wide as 4 inches (Bliss and others, 1988). The veins are in joints and locally are offset by cross faults (Bliss and others, 1988). According to Eden (2000) the rocks in the area are Devonian black metasiltstone, phyllite and schists.

Six samples of vein material contain 0.02 to $0.06 \mathrm{ppm}$ gold and from less than $0.1 \mathrm{ppm}$ to 0.2 ppm silver (Bliss and others, 1988). Two samples of bedrock near the veins contain $0.03 \mathrm{ppm}$ gold. Samples across the veins contained $33.8 \%$ to $44.5 \%$ antimony (Mulligan, 1974). Several more recent samples of selected quartz-vein material contain 151 to 1,716 ppb gold (Kurtak and others, 1999).

Five tons of stibnite ore was recovered from sluice operations on upper Smith Creek and shipped during World War II (Joesting, 1943). Joesting attributed at least some of this production to the Jones \& Boyle prospect, but his description of its source as upper Smith Creek contradicts the location of the Jones \& Boyle prospect described by Ebbley \& Wright (1948). More likely, the source of the stibnite was the unnamed prospect farther up Smith Creek Valley (WI130), or all three of the stibnite prospects located along Smith Creek (WI114, WI115 and WI130).

\section{Alteration:}

The phyllite wallrock adjacent to the veins is bleached (Bliss and others, 1988).

Age of mineralization:

\section{Deposit model:}

Sb-Au vein (Nokleberg and others, 1987), as adapted from a simple Sb deposit model (Cox and Singer, 1986; model 27d)

Deposit model number (After Cox and Singer, 1986 or Bliss, 1992): 
$27 d$

Production Status: Undetermined.

Site Status: Inactive

Workings/exploration:

The veins were exposed by placer operations, but apparently nothing more than sampling has been done on the veins. However, see the Production field for possible stibnite production.

\section{Production notes:}

Five tons of stibnite ore was recovered from sluice operations on upper Smith Creek and shipped during World War II (Joesting, 1943). Joesting attributed at least some of this production to the Jones \& Boyle prospect, but his description of its source as upper Smith Creek contradicts the location of the Jones \& Boyle prospect described by Ebbley \& Wright (1948). More likely, the source of the stibnite was the unnamed prospect farther up Smith Creek Valley (WI130), or all three of the stibnite prospects located along Smith Creek (WI114, WI115 and WI130).

\section{Reserves:}

\section{Additional comments:}

\section{References:}

Joesting, 1943; Ebbley and Wright, 1948; Saunders, 1954; Berg and Cobb, 1967; Heiner and Wolff, 1968; Brosge and Reiser, 1972; Cobb, 1973 (B1374); Mulligan, 1974; Grybeck, 1977; Dillon, 1982; Bliss and others, 1988; Kurtak and others, 1999; Eden, 2000.

Primary reference: Ebbley and Wright, 1948

Reporter(s): J.M. Britton (Anchorage)

Last report date: $8 / 9 / 2002$ 


\section{Site name(s): Wannemaker and Wortman; Workman's Bench}

Site type: Prospect

ARDF no.: WI115

Latitude: 67.4689

Quadrangle: WI B-1

Longitude: 150.2241

Location description and accuracy:

This prospect is at an elevation of about 1,800 feet on the south side of lower Smith Creek, 0.2 mile east of the junction of Smith and Nolan Creeks. A mine symbol on the Wiseman B-1 topographic map accurately represents the location of this prospect.

\section{Commodities:}

Main: $\mathrm{Au}, \mathrm{Sb}$

Other: $\mathrm{As}, \mathrm{Hg}(?), \mathrm{Pb}(?)$

Ore minerals: Arsenopyrite, cinnabar(?), galena(?), gold, stibnite

Gangue minerals: Ankerite(?), calcite(?), dolomite(?), quartz

\section{Geologic description:}

This prospect consists of a 3 to 4 inch-wide quartz-stibnite vein exposed in a trench about 150 feet above creek level on the south side of Smith Creek. The stibnite fills open spaces between quartz crystals with euhedral terminations deposited along the margins of the vein (Ebbley and Wright, 1948). Mulligan (1974) noted that the vein occupies a vertical fissure that cuts across a flat-lying, blue-gray phyllite. Selected rock samples from this prospect contain as much as $12.2 \mathrm{ppm}$ gold and are anomalous in arsenic (Eden, 2000) and up to 58.3\% Sb (Mulligan, 1974). Eden, based on geochemical data and not direct observation, suggests that accessory galena and cinnabar may accompany the primary stibnite-arsenopyrite-gold mineralization.

Eden (2000) describes auriferous quartz veins containing stibnite and arsenopyrite in the general area. Calcite, ankerite and minor dolomite accompany the quartz at the margins of these veins, which strike $\mathrm{N} 44$ E and dip nearly vertically. The gold is mostly near the margins of the veins and is rare in the stibnite (Eden, 2000).

\section{Alteration:}

The vein does not show an alteration envelope (Eden, 2000).

Age of mineralization:

Deposit model:

Sb-Au vein (Nokleberg and others, 1987), as adapted from a simple Sb deposit model (Cox and Singer, 1986; model 27d)

Deposit model number (After Cox and Singer, 1986 or Bliss, 1992): $27 d$

Production Status: None

Site Status: Inactive

Workings/exploration: 
The vein is exposed for $8 \mathrm{ft}$ along strike in a surface trench (Mulligan, 1974).

\section{Production notes:}

Reserves:

Additional comments:

See also Jones and Boyle (WI114).

\section{References:}

Ebbley and Wright, 1948; Saunders, 1954; Brosge and Reiser, 1960; Heiner and Wolff, 1968; Cobb, 1972 (MF-469); Mulligan, 1974; Cobb, 1976 (OF76-340); Grybeck, 1977; Dillon, 1982; Bliss and others, 1988; Kurtak and others, 1999; Eden, 2000; Kurtak and others, 2002.

Primary reference: Eden, 2000

Reporter(s): J.M. Britton (Anchorage)

Last report date: $8 / 9 / 2002$ 


\section{Site name(s): Smith Creek; Smith Gulch}

Site type: Mine

ARDF no.: WI116

Latitude: 67.4601

Quadrangle: WI B-1

Longitude: 150.1622

Location description and accuracy:

Smith Creek is a west-flowing tributary to Nolan Creek; it about half way between the mouth of Nolan Creek and Archibald Creek. The center of the placer workings on Smith Creek is at an elevation of 1,750 feet, about 0.5 mile east of Nolan Creek. The workings extend for approximately 1.5 miles along the creek. The location is accurate.

\section{Commodities:}

Main: $\mathrm{Au}$

Other: $\mathrm{Sb}$

Ore minerals: Gold, stibnite

\section{Gangue minerals:}

\section{Geologic description:}

According to Maddren (1913), the placer deposits in the Nolan Creek basin -- including Smith Creek -occur in the shallow gravels of the modern channel, as bench deposits, and in deep, frozen gravels. Mining of the shallow gravels began in 1903, two years after their discovery. Maddren (1913) described the gold from upper Smith Creek as mostly rough, angular grains; the gold becomes progressively more rounded and coarser downstream. Some of the gold near the head of the Smith Creek is coated by a white substance that Maddren did not identify although he suspected that it might be lime.

The gravel along the lower 2 miles of the modern channel of Smith Creek was selectively worked in richer spots during the earliest mining activity, but there is little information about this early mining. Gravel in the modern channel that was mined in the 1920's and 1930's were 6 to 20 feet thick. The gravel was frozen, coarse and subangular, and contained a few boulders. The gold was both coarse, rough and pitted, and smooth, rounded and waterworn. The value of the ground was about $\$ 0.30$ per square foot of bedrock (gold at $\$ 20.67$ per ounce) and the average fineness of the gold was about 950 .

The deep channel on Smith Creek rose from a depth of 135 feet near the mouth to eventually coincide upstream with the modern channel. By 1937, this deep channel was considered to be mined out by the methods available at the time.

Reed (1938) reported that remnants of the bench channel on Smith Creek had been mined at several locations along the creek. The gravel was frozen and generally coarse and subangular. The gold from one of these locations was mostly coarse, unworn and pitted, but some was smooth, rounded and worn. This gold occurred throughout the gravel but most was in the lower few feet; there were no large nuggets. The fineness was about 950 .

Based on analysis of six gold samples, Eden (2000) concluded that the gold occurs in two different populations defined by either high or low silver content. The fineness of these six samples ranged from 925 to 986. Eden also suggests that the gold in the Nolan-Hammond area has been derived from two gold-bearing vein systems in the area. The rocks in the valley of Smith Creek are micaceous schist, phyllite, and slate (Eden, 2000).

\section{Alteration:}


Age of mineralization:

Quaternary.

Deposit model:

Placer Au (Cox and Singer, 1986; model 39a)

Deposit model number (After Cox and Singer, 1986 or Bliss, 1992):

$39 a$

Production Status: Yes

Site Status: Active?

Workings/exploration:

Smith Creek was worked by hand-mining methods from about 1903 until the early 1960's. The hand methods included hydraulic washing of the gravel into sluice boxes.

\section{Production notes:}

Maddren (1913) reported that \$208,000 (about 10,400 oz.) in gold was produced from Smith Creek from 1903 to 1909. Eden (2000) reports that a total of 15,141.30 ounces of gold were produced from Smith Creek between 1904 and 1999. Cobb (1973) notes that 5 tons of placer and lode stibnite was recovered from Smith Creek and shipped during World War II.

\section{Reserves:}

The Internet page of Silverado Gold Mines Ltd., the current owner/operator of much of the Nolan Creek area, indicates that they consider the Smith Creek area to contain 7,571 ounces of gold in probable and possible resources (http://www.silverado.com/s/PropertyInformation.asp).

\section{Additional comments:}

See also: Wannemaker and Wortman (WI115); Jones and Boyle (WI114); Unnamed (in Smith Creek valley) (WI130).

\section{References:}

Brooks, 1908; Maddren, 1910; Brooks, 1913; Maddren, 1913; Brooks, 1915; Brooks, 1916; Brooks, 1918; Brooks, 1922; Wimmler, 1925; Smith, 1930 (B810); Smith, 1930 (B813); Smith, 1932; Smith, 1933 (B836); Smith, 1936; Smith, 1937; Reed, 1938; Smith, 1938; Heiner and Wolff, 1968; Cobb, 1972 (MF469); Cobb, 1973 (B1374); Mulligan, 1974; Cobb, 1976 (OF76-340); Grybeck, 1977; Dillon, 1982; Maas, 1987; Bliss and others, 1988; Bundtzen and others, 1990; Bundtzen and others, 1992; Kurtak and others, 1999; Eden, 2000; Kurtak and others, 2002.

Primary reference: Reed, 1938

Reporter(s): J.M. Britton (Anchorage)

Last report date: $8 / 9 / 2002$ 


\section{Site name(s): Kelly Gulch; Kelly's Gulch; Kelly's Mistake}

Site type: Mine

ARDF no.: WI117

Latitude: 67.2215

Quadrangle: WI B-1

Longitude: 150.0550

Location description and accuracy:

Kelly Gulch is a short, east-flowing tributary to the Middle Fork, Koyukuk River; its mouth is about 3 miles north of Coldfoot. The exact location of placer workings on this creek is unknown. The mine is arbitrarily located on the creek at an elevation of about 1,300 feet.

\section{Commodities:}

Main: $\mathrm{Au}$

Other:

Ore minerals: Gold

Gangue minerals:

Geologic description:

Maddren (1913) indicates that some mining was done on Kelly Gulch in 1901. Reed (1938) reported that an effort to mine in 1937 was abandoned before any significant results were obtained. No other information is available.

Alteration:

Age of mineralization:

Quaternary.

Deposit model:

Placer Au (Cox and Singer, 1986; model 39a)

Deposit model number (After Cox and Singer, 1986 or Bliss, 1992):

$39 \mathrm{a}$

Production Status: Yes

Site Status: Inactive

Workings/exploration:

Some mining, probably by open cut.

Production notes:

The mine produced $\$ 500$ (about 25 ounces) in gold in 1901 (Maddren, 1913).

Reserves:

Additional comments: 


\section{References:}

Maddren, 1910; Maddren, 1913; Reed, 1938; Heiner and Wolff, 1968; Cobb, 1972 (MF-469); Mulligan, 1974; Cobb, 1976 (OF76-340); Maas, 1987; Bliss and others, 1988.

Primary reference: Reed, 1938

Reporter(s): J.M. Britton (Anchorage)

Last report date: 8/9/2002 


\section{Site name(s): Emma Creek}

Site type: Mine

ARDF no.: WI118

Latitude: 67.2763

Quadrangle: WI B-1

Longitude: 150.1469

Location description and accuracy:

Emma Creek is an east-flowing tributary to the Middle Fork, Koyukuk River; its mouth is about 4.5 miles north of Coldfoot. The coordinates are about 0.8 mile upstream from the mouth; placer mining has occurred for about 0.5 mile downstream and 2 miles upstream. The location is accurate.

\section{Commodities:}

Main: $\mathrm{Au}$

Other:

Ore minerals: Gold

\section{Gangue minerals:}

\section{Geologic description:}

Gold was discovered on Emma Creek in 1900. The gold occurs in the modern channel and on a high bench. The productive portion of the modern channel is centered in a steep canyon cut through crystalline limestone. The canyon begins about a mile above the mouth of Emma Creek and extends upstream 1/2 mile or more. Most of the placer gold in this part of Emma Creek was concentrated at the upper end of the canyon, both within the canyon and in a gravel fan at its lower end. The richest ground was at the lower end of the canyon (Maddren, 1913).

Gold also occurs in a high bench channel on the south side of Emma Creek about a half mile from the mouth. This channel lies about 30 feet above the modern creek bed and is approximately 150 feet wide. Toward the Middle Fork, it diverges from the modern creek bed and swings to the southeast. The bench gravel is small and waterworn and contains numerous granite and limestone boulders (Reed, 1938). The depth to bedrock varies from 5 to 91 feet. From the top, the section consists of a foot of moss, 0-50 feet of sand and clay, and 4-40 feet of gravel. All of the gravel, except the lower 4-5 feet is frozen. The gold is coarse and angular and commonly attached to quartz (Bliss and others, 1988). The gold on bedrock was in small nuggets valued at $\$ 0.25$ to $\$ 1$ (gold at $\$ 20$ per ounce.) The bedrock in the area around the high channel is micaceous and graphitic schist with bands of limestone (Reed, 1938). Bliss and others (1988) suggested that the source of the gold may be the numerous quartz veins that occur in the drainage area. Three samples of gold from Emma Creek have a median fineness of 905 and median trace elements contents of $0.047 \%$ copper, 50 ppm lead, 80 ppm antimony, and 0.31\% mercury (Mosier and Lewis, 1986).

Early mining of the modern channel was by sluicing, and of the high bench by drifting and open cuts. Mining in the modern channel was complicated by numerous large boulders, 3 to 10 feet in diameter, above and below the canyon. Small-scale mining was reported in 1974 (Mulligan, 1974). According to Kurtak and others (2002) a suction dredge has been used on Emma creek to clean out potholes in the bedrock. Mining on Emma Creek has been regularly reported during the 1980's, 1990's (Eakins and others, 1983 and 1985; Bundtzen and others, 1984, 1986, 1990, and 1992; Green and others, 1989; Swainbank and others, 1993), and as recently as 2000 (Szumigala and others, 2001).

Most of the production from this creek occurred prior to 1930. The value of the gold produced from 1900 to 1909 was estimated to be \$160,000 (gold at \$20/ounce), most of which was produced from 1900 to 1902 (Maddren, 1913). According to Reed (1938) as much as \$12,000 (gold at \$35/ounce) was produced from the high channel through 1928. 


\author{
Alteration: \\ Age of mineralization: \\ Quaternary. \\ Deposit model: \\ Placer Au (Cox and Singer, 1986; model 39a) \\ Deposit model number (After Cox and Singer, 1986 or Bliss, 1992): \\ $39 \mathrm{a}$
}

Production Status: Yes; small

Site Status: Active?

Workings/exploration:

Early mining of the modern channel was by sluicing, and of the high bench by drifting and open cuts. Mining in the modern channel was complicated by numerous large boulders, 3 to 10 feet in diameter, above and below the canyon. Small-scale mining was reported in 1974 (Mulligan, 1974). According to Kurtak and others (2002) a suction dredge has been used on Emma creek to clean out potholes in the bedrock. Mining on Emma Creek has been regularly reported during the 1980's, 1990's (Eakins and others, 1983 and 1985; Bundtzen and others, 1984, 1986, 1990, and 1992; Green and others, 1989; Swainbank and others, 1993), and as recently as 2000 (Szumigala and others, 2001).

\title{
Production notes:
}

Most of the production from this creek occurred prior to 1930. The value of the gold produced from 1900 to 1909 was estimated to be $\$ 160,000$ (gold at $\$ 20 /$ ounce), most of which was produced from 1900 to 1902 (Maddren, 1913). According to Reed (1938) as much as $\$ 12,000$ (gold at $\$ 35 /$ ounce) was produced from the high channel through 1928.

\section{Reserves:}

\section{Additional comments:}

\section{References:}

Schrader, 1900; Schrader, 1904; Brooks, 1908; Maddren, 1910; Brooks, 1913; Maddren, 1913; Brooks, 1915; Brooks, 1918; Wimmler, 1925; Reed, 1938; Brosge and Reiser, 1960; Heiner and Wolff, 1968; Cobb, 1972 (MF-469); Mulligan, 1974; Cobb, 1976 (OF76-340); Grybeck, 1977; Dillon, 1982; Eakins and others, 1983; Bundtzen and others, 1984; Eakins and others, 1985; Bundtzen and others, 1986; Bundtzen and others, 1987; Mosier and Lewis, 1986; Maas, 1987; Bliss and others, 1988; Green and others, 1989; Bundtzen and others, 1990; Bundtzen and others, 1992; Swainbank and others, 1993.

Primary reference: Reed, 1938

Reporter(s): J.M. Britton (Anchorage)

Last report date: $8 / 9 / 2002$ 


\section{Site name(s): Emma Dome}

Site type: Occurrence

ARDF no.: WI119

Latitude: 67.2977

Quadrangle: WI B-1

Longitude: 150.2179

Location description and accuracy:

This occurrence is at an elevation of about 3,900 feet, in the SE1/4 section 22, T. 29 N., R. 13 W., of the Fairbanks Meridian. It is 0.2 mile south of hill 4465. The location is accurate.

Commodities:

Main: $\mathrm{Ag}, \mathrm{Au}, \mathrm{Cu}$

Other:

Ore minerals: Malachite, unspecified copper sulfides

Gangue minerals: Quartz

Geologic description:

This occurrence is a quartz vein in Devonian schist and marble (Brosge and Reiser, 1972). A sample contains 0.04 to $0.079 \mathrm{ppm}$ gold and 6.0 to $19 \mathrm{ppm}$ silver. Brosge and Reiser (1960) earlier reported copper sulfides and malachite along the contact between the schist and marble.

\section{Alteration:}

Oxidation of copper mineral(s).

Age of mineralization:

Deposit model:

Deposit model number (After Cox and Singer, 1986 or Bliss, 1992):

Production Status: No

Site Status: Inactive

Workings/exploration:

Only surface sampling.

Production notes:

Reserves:

Additional comments:

This occurrence is in Gates of the Arctic National Park and Preserve.

\section{References:}

Brosge and Reiser, 1960; Brosge and Reiser, 1970; Brosge and Reiser, 1972; Cobb, 1972 (MF-469); Cobb, 1976 (OF76-340); Grybeck, 1977; Maas, 1987; Bliss and others, 1988. 
Primary reference: Brosge and Reiser, 1972

Reporter(s): J.M. Britton (Anchorage)

Last report date: $8 / 9 / 2002$ 


\section{Site name(s): Acme Creek}

Site type: Mine

ARDF no.: WI120

Latitude: 67.4839

Quadrangle: WI B-1

Longitude: 150.2293

Location description and accuracy:

Acme Creek is a southeast-flowing tributary to lower Nolan Creek . Its mouth is 1.5 miles upstream of the confluence of Nolan and Wiseman Creeks. The mine workings are on lower Acme Creek just upstream from its mouth.

\section{Commodities:}

Main: $\mathrm{Au}$

Other:

Ore minerals: Gold

Gangue minerals:

Geologic description:

Reed (1938) reported that a small amount of fine gold was mined on Acme Creek from a deep channel 70 to 110 feet below the surface, a few hundred feet upstream from the junction of the Acme Creek deep channel and the deep channel of Nolan Creek (WI101). The gold from Acme Creek was fine and bright and differs from that in Nolan Creek. Reed (1938) noted that gold had not been found in either the present or high channels of Acme Creek.

\section{Alteration:}

Age of mineralization:

Quaternary.

\section{Deposit model:}

Placer Au (Cox and Singer, 1986; model 39a)

Deposit model number (After Cox and Singer, 1986 or Bliss, 1992):

$39 \mathrm{a}$

Production Status: Undetermined.

Site Status: Probably inactive

Workings/exploration:

Some mining on a deep channel just above the mouth of Acme Creek.

Production notes:

Probably some gold production.

Reserves: 
Additional comments:

\section{References:}

Reed, 1938; Cobb, 1972 (MF-469); Cobb, 1976 (OF76-340); Grybeck, 1977; Maas, 1987; Bundtzen and others, 1992.

Primary reference: Reed, 1938

Reporter(s): J.M. Britton (Anchorage)

Last report date: $8 / 9 / 2002$ 


\section{Site name(s): Cow Creek}

Site type: Occurrence

ARDF no.: WI121

Latitude: 67.3762

Quadrangle: WI B-1

Longitude: 150.1674

Location description and accuracy:

Cow Creek is a small, east-flowing tributary to the Middle Fork, Koyukuk River. Its mouth is about 1.8 miles southwest of Wiseman. The occurrence, as plotted by Brosge and Reiser (1960), is at an elevation of about 1,500 feet, in the SE1/4 section 26, T. 30 N., R. 12 W., of the Fairbanks Meridian. It is just north of Cow Creek, on a small unnamed, north tributary. The location is accurate within one-half mile.

\section{Commodities:}

Main: $\mathrm{Cu}$

Other:

Ore minerals: Copper sulfides, malachite

Gangue minerals:

Geologic description:

Brosge and Reiser (1960) noted copper sulfides and malachite staining in Devonian(?) schist and marble.

\section{Alteration:}

Alteration of copper minerals.

Age of mineralization:

Deposit model:

Deposit model number (After Cox and Singer, 1986 or Bliss, 1992):

Production Status: None

Site Status: Inactive

Workings/exploration:

Only surface sampling.

Production notes:

Reserves:

Additional comments:

References:

Brosge and Reiser, 1960; Cobb, 1972 (MF-469); Cobb, 1976 (OF76-340); Grybeck, 1977; Maas, 1987;

Bliss and others, 1988. 
Primary reference: Brosge and Reiser, 1960

Reporter(s): J.M. Britton (Anchorage)

Last report date: $8 / 9 / 2002$ 


\section{Site name(s): Moose Creek; Moose Gulch}

Site type: Occurrence

ARDF no.: WI122

Latitude: 67.3214

Quadrangle: WI B-1

Longitude: 150.4058

Location description and accuracy:

Moose Creek is a west tributary to the Middle Fork, Koyukuk River; its mouth is about 3 miles southsouthwest of Wiseman. The exact location of this occurrence is unknown and the location is arbitrarily placed about 0.5 mile upstream from the mouth of Moose Creek.

\section{Commodities:}

Main: $\mathrm{Au}$

Other:

Ore minerals: Gold

Gangue minerals:

Geologic description:

Maddren (1913) described Moose Creek as a small gulch containing gold prospects, but numerous large boulders prevented any work from being done. No other information is available on this occurrence.

\section{Alteration:}

Age of mineralization:

Quaternary.

Deposit model:

Placer Au (Cox and Singer, 1986; model 39a)

Deposit model number (After Cox and Singer, 1986 or Bliss, 1992):

$39 \mathrm{a}$

Production Status: None

Site Status: Inactive

Workings/exploration:

Surface prospecting.

Production notes:

Reserves:

Additional comments:

References:

Maddren, 1913; Reed, 1938; Heiner and Wolff, 1968; Cobb, 1976 (OF76-340); Maas, 1987. 
Primary reference: Maddren, 1913

Reporter(s): J.M. Britton (Anchorage)

Last report date: $8 / 9 / 2002$ 


\section{Site name(s): Jap Creek}

Site type: Prospects

ARDF no.: WI123

Latitude: 67.4143

Quadrangle: WI B-1

Longitude: 150.1304

Location description and accuracy:

Jap Creek, which is not named on the Wiseman B-1 topographic map, is a west tributary to Wiseman Creek. It joins Wiseman Creek about 1.5 miles northwest of Wiseman. The locations of placer prospects along the creek is uncertain and the prospects are arbitrarily placed about 0.2 mile above its mouth.

\section{Commodities:}

Main: $\mathrm{Au}, \mathrm{Sb}(?)$

Other:

Ore minerals: Gold, stibnite(?)

Gangue minerals:

Geologic description:

Gold occurs in the gravels of Jap Creek but not in amounts sufficient for mining (Mulligan, 1974). Two stream-sediment samples contain 700 ppm and 3,000 ppm antimony (Brosge and Reiser, 1972).

\section{Alteration:}

Age of mineralization:

Quaternary.

Deposit model:

Placer Au (Cox and Singer, 1986; model 39a)

Deposit model number (After Cox and Singer, 1986 or Bliss, 1992): $39 \mathrm{a}$

Production Status: None

Site Status: Inactive

Workings/exploration:

Prospecting only.

Production notes:

Reserves:

Additional comments:

References:

Brosge and Reiser, 1972; Mulligan, 1974; Cobb, 1976 (OF76-340). 
Primary reference: Mulligan, 1974

Reporter(s): J.M. Britton (Anchorage)

Last report date: $8 / 9 / 2002$ 


\section{Site name(s): Thompson Pup; Thompson Gulch}

Site type: Mine

ARDF no.: WI124

Latitude: 67.4898

Quadrangle: WI B-1

Longitude: 150.1848

Location description and accuracy:

Thompson Pup is a 0.8-mile-long tributary to Fay Creek. The junction of Fay Creek and and Thompson Pup is about 1 mile northwest of the summit of Smith Creek Dome. Placer gold has been mined along most of Thompson Pup. The coordinates are at the mine symbol on the 1:63,360-scale topographic map, a short distance above the mouth of Thompson Creek. The location is accurate.

\section{Commodities:}

Main: $\mathrm{Au}$

Other: As

Ore minerals: Arsenopyrite, gold

\section{Gangue minerals:}

\section{Geologic description:}

Thompson Pup is generally described together with the Nolan Creek placers, not as a separate placer deposit. There is, however, little doubt that there are placer gold deposits along most of Thompson Pup. Work on Thompson Pup was noted by Holdsworth (1957) and Williams (1950) describe a hydraulic and ground sluicing operation on Thompson Gulch. Eden (2000) reports that a total of 3,100 ounces of gold were produced from Thompson Pup between 1904 and 1999. Williams also reports that there were several channels and that the fineness of the gold being recovered was unusually high; the gold averages about 940 fine with nuggets up to 982 fine. Mosier and Lewis (1986), however, indicate that the fineness is generally lower, in the range of 777 to 926 . Eden (2000) indicates that the gold placer deposits extend up Thompson Pup for approximately a half mile above Fay Creek, and that the gold from Thompson Pup is crystalline. The crystalline nature of the gold distinguishes it from other placer gold in the Nolan Creek area and suggests that the gold has not traveled far from its source. Kurtak and others (1999) analyzed arsenopyrite crystals from placer concentrates from Thompson Pup; they contain as much as 1,964 ppb gold, but they may have been contaminated. The rocks in the area consist of micaceous and chloritic schists, phyllite, and metasiltstone (Eden, 2000).

\section{Alteration:}

Age of mineralization:

Quaternary.

\section{Deposit model:}

Placer Au (Cox and Singer, 1986; model 39a)

Deposit model number (After Cox and Singer, 1986 or Bliss, 1992): $39 \mathrm{a}$

Production Status: Yes 
Site Status: Active?

\section{Workings/exploration:}

Thompson Pup was mined by hand methods, including ground sluicing, and by hydraulic methods. Mining was last reported in 1994 (Kurtak and others, 2002).

Production notes:

Eden (2000) reports that a total of 3,100 ounces of gold were produced from Thompson Pup between 1904 and 1999.

\section{Reserves:}

\section{Additional comments:}

References:

Williams, 1950; Holdsworth, 1957; Cobb, 1972 (MF-469); Cobb, 1973 (B1374); Cobb, 1976 (OF76-340); Armstrong, 1985; Maas, 1987; Kurtak and others, 1999; Eden, 2000; Kurtak and others, 2002.

Primary reference: Eden, 2000

Reporter(s): J.M. Britton (Anchorage)

Last report date: $8 / 9 / 2002$ 


\section{Site name(s): Pasco Creek}

Site type: Occurrence

ARDF no.: WI125

Latitude: 67.4663

Quadrangle: WI B-1

Longitude: 150.3082

Location description and accuracy:

Pasco Creek is a short, west tributary to Wiseman Creek. It heads in Pasco Pass and flows into Wiseman Creek about 1 mile west of Nolan Creek Lake. The location of placer occurrences on Pasco creek is uncertain and the coordinates are arbitrarily placed near its mouth.

\section{Commodities:}

Main: $\mathrm{Au}$

Other:

Ore minerals: Gold

Gangue minerals:

Geologic description:

Schrader (1900) reported placer gold on Pasco Creek but no other information is available.

\section{Alteration:}

Age of mineralization:

Quaternary.

Deposit model:

Placer Au (Cox and Singer, 1986; model 39a)

Deposit model number (After Cox and Singer, 1986 or Bliss, 1992):

$39 \mathrm{a}$

Production Status: None

Site Status: Inactive

Workings/exploration:

Schrader (1900) reported placer gold on Pasco Creek but no other information is available.

Production notes:

\section{Reserves:}

\section{Additional comments:}

\section{References:}

Schrader, 1900; Heiner and Wolff, 1968; Cobb, 1976 (OF76-340); Cobb, 1981 (OF81-732); Maas, 1987;

Kurtak and others, 2002. 
Primary reference: Reed, 1938

Reporter(s): J.M. Britton (Anchorage)

Last report date: $8 / 9 / 2002$ 


\section{Site name(s): Quartz Creek}

Site type: Mine

ARDF no.: WI126

Latitude: 67.2462

Quadrangle: WI B-1

Longitude: 150.3004

Location description and accuracy:

Quartz Creek is a southeast-flowing tributary to Porcupine Creek. It joins Porcupine Creek about 1.5 miles north-northwest of the junction of Porcupine Creek and the Middle Fork, Koyukuk River. The location of placer mining on Quartz Creek is uncertain. Cobb (1972 [MF469]) and Dillon (1985) indicate that mining took place near the junction with Porcupine Creek and Quartz Creek, about 3 miles west-southwest of Coldfoot.

\section{Commodities:}

Main: $\mathrm{Au}$

Other:

Ore minerals: Gold

\section{Gangue minerals:}

\section{Geologic description:}

Hand-mining in the modern channel of Quartz Creek produced about \$2,500 in gold (about 120 ounces) through 1937 (Reed, 1938). The depth to bedrock is about three feet. Mining was reported on Porcupine and Quartz Creeks in 2000 (Kurtak and others, 2002).

\section{Alteration:}

Age of mineralization:

Quaternary.

\section{Deposit model:}

Placer Au (Cox and Singer, 1986; model 39a)

Deposit model number (After Cox and Singer, 1986 or Bliss, 1992):

$39 \mathrm{a}$

Production Status: Yes

Site Status: Active?

Workings/exploration:

Hand mining occurred at various times through 1937 (Reed, 1938). Mining was reported on Porcupine and Quartz Creeks in 2000 (Kurtak and others, 2002).

Production notes:

Hand-mining produced about \$2,500 in gold (approximately 120 ounces) through 1937 (Reed, 1938).

\section{Reserves:}


Additional comments:

See also Porcupine Creek (WI152).

\section{References:}

Reed, 1938; Saunders, 1954; Cobb, 1972 (MF-469); Cobb, 1976 (OF76-340); Dillon, 1982; Bliss and others, 1988; Kurtak and others, 2002.

Primary reference: Reed, 1938

Reporter(s): J.M. Britton (Anchorage)

Last report date: $8 / 9 / 2002$ 


\section{Site name(s): Unnamed (near summit of Smith Creek Dome)}

Site type: Occurrence

ARDF no.: WI127

Latitude: 67.4757

Quadrangle: WI B-1

Longitude: 150.1686

Location description and accuracy:

This occurrence is at an elevation of 3,800 feet, about 0.1 mile southeast of the summit of Smith Creek

Dome. The location is accurate.

Commodities:

Main: $\mathrm{Ag}, \mathrm{Au}$

Other: $\mathrm{Pb}$

Ore minerals: Galena(?), gold(?), pyrite

Gangue minerals: Quartz

\section{Geologic description:}

The only information on this occurrence is based on two rock samples collected from an outcrop; one is a sample of a quartz vein cutting quartz-mica schist (Eden, 2000, no. 10741), and the other a sample of quartz-muscovite schist that contained pyrite cubes and iron oxide (Eden, 2000, no. 10720). The quartzvein sample contains $46 \mathrm{ppb}$ gold; the schist sample contains 2,234 ppb gold, 7.2 ppm silver and 3,500 ppm lead. The rocks on top of Smith Creek Dome are Upper Devonian, banded quartzite, interbedded with chloritic quartzite and quartz-mica schist (Eden, 2000).

Eden (2000) reports gold-quartz veins at several localities in the general Nolan Creek area, including this occurrence. These veins generally are narrow, $1 \mathrm{~mm}$ to a few $\mathrm{cm}$ in width, strike northwest-southeast, and dip nearly vertically. The vein mineralogy varies. . Most consist primarily of quartz and lesser amounts of calcite, ankerite and dolomite, with gold and arsenopyrite. Accessory minerals include pyrite, marcasite, chalcopyrite, pyrrhotite, hematite, sphalerite, galena, and rutile. Stibnite is rare in these veins.

\section{Alteration:}

No observed wallrock alteration.

Age of mineralization:

Deposit model:

Low-sulfide Au-quartz vein (Cox and Singer, 1986; model 36a)

Deposit model number (After Cox and Singer, 1986 or Bliss, 1992): $36 \mathrm{a}$

Production Status: None

Site Status: Inactive

Workings/exploration:

Only surface sampling. 
Production notes:

Reserves:

Additional comments:

References:

Kurtak and others, 1999; Eden, 2000.

Primary reference: Eden, 2000

Reporter(s): J.M. Britton (Anchorage)

Last report date: $8 / 9 / 2002$ 


\section{Site name(s): Unnamed (near the head of Thompson Pup)}

Site type: Occurrence

ARDF no.: WI128

Latitude: 67.4956

Quadrangle: WI B-1

Longitude: 150.1669

Location description and accuracy:

This occurrence represents several sites that cover an area approximately 0.5 miles in diameter; the center of the area is at an elevation of about 2,900 feet near the head of Thompson Pup. Thompson Pup is a short tributary to Fay Creek (WI112). The location is accurate.

\section{Commodities:}

Main: $\mathrm{Au}$

Other: $\mathrm{Ag}, \mathrm{As}, \mathrm{Cu}, \mathrm{Sb}$

Ore minerals: Arsenopyrite, chalcopyrite(?), gold, pyrite, pyrrhotite, stibnite(?)

Gangue minerals: Limonite, quartz, siderite

\section{Geologic description:}

This occurrence consists of sulfide-bearing quartz-carbonate(siderite) veins at the head of Thompson Pup (Kurtak and others, 1999). Several samples of the veins contain up to 186 ppb gold, 0.4 ppm silver, $0.35 \%$ antimony, 3,062 ppm copper, and 765 ppm arsenic. The veins are in phyllite; they are up to 4 feet thick; and contain varying amounts of arsenopyrite, pyrite, pyrrhotite, limonite, and chalcopyrite(?). Eden (2000) describes three quartz-arsenopyrite-gold(?) veins in Thompson Pup, but not their exact location. He also notes that data from an unpublished report indicate that these veins contain gold, but that assay results have not been encouraging. The rocks in the area are mostly micaceous schist, phyllite, and metasiltstone (Eden, 2000).

\section{Alteration:}

Age of mineralization:

\section{Deposit model:}

Low-sulfide Au-quartz vein (Cox and Singer, 1986; model 36a)

Deposit model number (After Cox and Singer, 1986 or Bliss, 1992): $36 \mathrm{a}$

Production Status: None

Site Status: Probably inactive

Workings/exploration:

Only surface sampling.

Production notes:

Reserves: 
Additional comments:

References:

Kurtak and others, 1999; Eden, 2000.

Primary reference: Kurtak and others, 1999

Reporter(s): J.M. Britton (Anchorage)

Last report date: $8 / 9 / 2002$ 


\section{Site name(s): Unnamed (on lower Wiseman Creek)}

Site type: Occurrence

ARDF no.: WI129

Latitude: 67.3804

Quadrangle: WI B-1

Longitude: 150.1584

Location description and accuracy:

This occurrence is at the lower end of the Wiseman Creek canyon about 0.5 mile west-northwest of Wiseman. The location is accurate.

Commodities:

Main: $\mathrm{Cu}$

Other:

Ore minerals: Chalcopyrite, chrysocolla

Gangue minerals: Gypsum, quartz

\section{Geologic description:}

Brosge and Reiser (1960) reported unspecified copper sulfides and malachite stains in Devonian(?) schist and marble. At the same location, Mulligan (1974) described narrow veins of quartz and dogtooth-spar gypsum in mica schist. Grab samples of quartz and gypsum float contained traces of chalcopyrite and chrysocolla (Mulligan, 1974). Dillon and Reifenstuhl (1990) mapped the rocks in the area as lower Paleozoic(?) or Proterozoic(?) marble and calcareous schist.

Alteration:

Age of mineralization:

Deposit model:

Deposit model number (After Cox and Singer, 1986 or Bliss, 1992):

Production Status: None

Site Status: Inactive

Workings/exploration:

Production notes:

Reserves:

Additional comments:

\section{References:}

Brosge and Reiser, 1960; Cobb, 1972 (MF-469); Mulligan, 1974; Cobb, 1976 (OF76-340); Maas, 1987;

Dillon and Reifenstuhl, 1990. 
Primary reference: Mulligan, 1974

Reporter(s): J.M. Britton (Anchorage)

Last report date: $8 / 9 / 2002$ 


\section{Site name(s): Unnamed (in Smith Creek)}

Site type: Prospect

ARDF no.: WI130

Latitude: 67.4631

Quadrangle: WI B-1

Longitude: 150.1458

Location description and accuracy:

This prospect is at an elevation of about 1,950 feet in Smith Creek, about 1 mile east of Nolan Creek. The location is accurate.

Commodities:

Main: $\mathrm{Au}, \mathrm{Sb}$

Other:

Ore minerals: Arsenopyrite, gold, stibnite

Gangue minerals: Ankerite, dolomite, quartz

\section{Geologic description:}

Eden (2000) describes quartz-stibnite-gold veins at three locations in the vicinity of Smith Creek. Two of the three locations described by Eden (2000, locations 266 \& 359) appear to correspond to the Wanemaker \& Wortman (WI115) and the Jones \& Boyle (WI114) prospects described by Ebbley and Wright (1948). The location described in this record is about a mile further upstream and was not described by Ebbley $\&$ Wright (1948). Reports of production of antimony from placer operations on Smith Creek may have covered one or more of these three locations.

The veins here consist of coarse-grained, white quartz with stibnite and arsenopyrite. The gold is mostly in the margins of the quartz veins but rare in the stibnite. Calcite, ankerite and minor dolomite also occur along the margins of the veins. The veins do not exhibit alteration envelopes. Thin quartz-carbonate veins, which represent a later stage of the mineralizing event, cut the quartz-stibnite-gold veins. The mineralized veins are 0.5 to 1.5 centimeters thick, strike N 55 E, and dip steeply (Eden, 2000). Two samples of sulfidebearing quartz veins contain 1,532 and 1,958 ppb gold, 5,772 ppm and 3,933 ppm arsenic and more than 2,000 ppm antimony (Eden, 2000, samples 11165 and 11166). The veins are near a fault contact between Devonian chloritic schist and a unit of Devonian gray-black phyllite, black slate, and black metasiltstone.

\section{Alteration:}

\section{Age of mineralization:}

\section{Deposit model:}

Sb-Au vein deposit (Nokleberg and others, 1987); or simple stibnite vein (Cox and Singer, 1986; model 27d)

Deposit model number (After Cox and Singer, 1986 or Bliss, 1992): $27 d$

Production Status: Yes

Site Status: Inactive 
Workings/exploration:

The veins were exposed by during placer mining. Apparently there is no other work on the veins beyond sampling.

Production notes:

Five tons of stibnite was recovered from sluice operations in the vicinity of the veins and shipped during World War II (Joesting, 1943).

\section{Reserves:}

\section{Additional comments:}

\section{References:}

Joesting, 1943; Ebbley and Wright, 1948; Saunders, 1954; Kurtak and others, 1999; Eden, 2000.

Primary reference: Eden, 2000

Reporter(s): J.M. Britton (Anchorage)

Last report date: $8 / 9 / 2002$ 


\section{Site name(s): Fortress}

Site type: Occurrence

ARDF no.: WI131

Latitude: 67.4994

Quadrangle: WI B-1

Longitude: 150.1451

Location description and accuracy:

This occurrence is at elevation of about 3,000 feet on the north end of the ridge at the head of Buckeye Gulch; it is about 0.4 mile east-northeast of the center of section 24, T. 31 N., R. 12 W., of the Fairbanks Meridian. The occurrence is the site of a gold-bearing sample that contained gold (Eden, 2000). Similar occurrences are included that occur south along the ridge for about 0.2 mile. The location is accurate.

\section{Commodities:}

Main: $\mathrm{Au}$

Other: As

Ore minerals: Gold, pyrite

Gangue minerals: Ankerite, calcite, hematite, quartz

\section{Geologic description:}

This occurrence consists of veins that contain coarse, white quartz crystals which fill cavities, and euhedral calcite crystals (Eden, 2000). Ankerite, with pyrite, and hematite after pyrite, occurs along the margins of the veins. The veins strike northwest-southeast, dip almost vertically, and are up to one inch thick. Several samples of the veins contain 5 to $58 \mathrm{ppb}$ gold and 15 to $138 \mathrm{ppm}$ arsenic (Kurtak and others, 1999). The samples were taken in quartz veins about 1 inch thick that contain minor pyrite, $+/$ - hematite, $+/$ - siderite. One continuous chip sample from an outcrop, described as a hematite- and pyrite-bearing quartz vein in phyllite, contains 8,301 ppb gold and 1,134 ppm arsenic (Eden, 2000, sample 10650). Eden (2000) notes that the occurrences at this site are extensions of a gold-quartz vein system in the Nolan Creek area (WI101). In general, the mineralization in the Nolan Creek consists of quartz veins with lesser calcite, ankerite and dolomite, arsenopyrite sometimes, and varying amounts of a variety of accessory sulfide and oxide minerals including pyrite, marcasite, chalcopyrite, pyrrhotite, hematite, sphalerite, galena, and rutile.

\section{Alteration:}

The wallrock adjoining the veins apparently is not altered.

\section{Age of mineralization:}

Deposit model:

Low-sulfide Au-quartz vein (Cox and Singer, 1986; model 36a)

Deposit model number (After Cox and Singer, 1986 or Bliss, 1992): $36 \mathrm{a}$

Production Status: None

Site Status: Inactive

Workings/exploration: 
Surface sampling and geologic mapping.

Production notes:

Reserves:

Additional comments:

References:

Kurtak and others, 1999; Eden, 2000.

Primary reference: Eden, 2000

Reporter(s): J.M. Britton (Anchorage)

Last report date: $8 / 9 / 2002$ 


\section{Site name(s): Unnamed (near southwest end of Midnight Dome)}

Site type: Occurrence

ARDF no.: WI132

Latitude: 67.4543

Quadrangle: WI B-1

Longitude: 150.0976

Location description and accuracy:

This occurrence is at an elevation of 3,700 feet, 0.2 mile west of hill 3860 on the south end of Midnight

Dome. The location is accurate.

Commodities:

Main: $\mathrm{Au}$

Other: $\mathrm{Cu}$

Ore minerals: Gold(?), malachite, pyrite

Gangue minerals: Quartz

\section{Geologic description:}

This occurrence consists of sulfide-bearing quartz veins in schist or quartzite (Eden, 2000). A sample of vein quartz found in float contains pyrite, malachite, and limonite, 179 ppb gold and 1,469 ppm copper. A sample of quartz vein collected in place contains pyrite and limonite, and 532 ppb gold. Eden (2000) interprets this occurrence as an extension of the system of auriferous quartz veins in the Nolan area. The rocks in the area are Upper Devonian chloritic schist and chloritic quartzite (Eden, 2000).

Alteration:

Iron-oxide alteration

Age of mineralization:

Deposit model:

Low-sulfide Au-quartz vein (Cox and Singer, 1986; model 36a)

Deposit model number (After Cox and Singer, 1986 or Bliss, 1992):

$36 \mathrm{a}$

Production Status: None

Site Status: Inactive

Workings/exploration:

Only limited surface sampling and geologic mapping.

Production notes:

Reserves:

Additional comments: 


\section{References:}

Kurtak and others, 1999; Eden, 2000.

Primary reference: Eden, 2000

Reporter(s): J.M. Britton (Anchorage)

Last report date: $8 / 9 / 2002$ 


\section{Site name(s): Unnamed (above Gold Bottom Gulch)}

Site type: Occurrence

ARDF no.: WI133

Latitude: 67.4727

Quadrangle: WI B-1

Longitude: 150.0806

Location description and accuracy:

This occurrence is located about 4.5 miles north of Wiseman near the top of the ridge at the head of Steep Gulch. The occurrence is at an elevation of 2,900 feet in about the center of the NE1/4 section 31, T. 31 N., R. 11 W., of the Fairbanks Meridian. The location is accurate.

\section{Commodities:}

Main: $\mathrm{Au}$

Other:

Ore minerals: Gold(?), hematite, pyrite

Gangue minerals: Quartz

Geologic description:

This occurrence consists of an auriferous, pyrite-bearing quartz vein. A select sample of the quartz vein contains 810 ppb gold (Eden, 2000). Eden indicates that this vein is an extension of a system of goldquartz veins in the Nolan area. The rocks in the area consist of quartz-mica schist interlayered with chlorite schist and phyllite (Eden, 2000). No other information is available.

Alteration:

Age of mineralization:

Deposit model:

Low-sulfide Au-quartz vein (Cox and Singer, 1986; model 36a)

Deposit model number (After Cox and Singer, 1986 or Bliss, 1992): $36 \mathrm{a}$

Production Status: None

Site Status: Inactive

Workings/exploration:

Surface sampling and geologic mapping.

Production notes:

Reserves:

Additional comments:

References: 
Kurtak and others, 1999; Eden, 2000.

Primary reference: Eden, 2000

Reporter(s): J.M. Britton (Anchorage)

Last report date: $8 / 9 / 2002$ 


\section{Site name(s): Roosevelt Creek; RO; Skroo}

Site type: Prospect

ARDF no.: WI134

Latitude: 67.1389

Quadrangle: WI A-6

Longitude: 152.8988

Location description and accuracy:

This prospect is located near Roosevelt Creek about two miles north of the Malamute Fork, Alatna River. A large claim group which extends about 10 miles east and west and 1 to 1.5 miles north and south, is shown by Dillon and others (1981, Plate 1 [AOF 133B]); it is presumed to correspond to this prospect. The location is accurate within 1 mile.

\section{Commodities:}

Main: $\mathrm{Cu}, \mathrm{Pb}, \mathrm{Zn}$

Other: $\operatorname{Ag}(?), \operatorname{Au}(?)$

Ore minerals: Chalcopyrite, galena, pyrite, sphalerite

\section{Gangue minerals:}

\section{Geologic description:}

Sparse published information about the Roosevelt Creek prospect principally cites oral communications and reports of unpublished industry data. The most recent of the published reports (Nokleberg and others, 1996) describes the Roosevelt Creek prospect as massive and disseminated(?) sulfides in metavolcanics, pelitic schists and marbles of the Devonian and Mississippian, Ambler sequence. The sulfides are described as probably chalcopyrite, sphalerite, and galena. Dillon and others (1986) map the general area of the prospect as Devonian, metavolcanic rocks and Proterozoic(?) or lower Paleozoic schists of various types, along with local marble. Grybeck (1977) indicates that the geology and geochemistry of the area is similar to that to the west in the Ambler district.

Kurtak and others (2002) examined the area during their study of the Koyukuk mining district. They report that the canyon on Roosevelt Creek exposes Devonian(?) muscovite schist, graphitic schist and metarhyolite in a sequence that trends generally east-west and dips 55o south. Drilling intersected narrow, discontinuous zones of massive to semi-massive pyrite, sphalerite, galena, and chalcopyrite mineralization in schist and metarhyolite.

Several rock samples collected along Roosevelt Creek in the vicinity of the presumed location of the prospect are described in Dillon and others (1981 [AOF 133B]) as felsic schists or felsites, most of which contain 1-2\% disseminated pyrite. One sample may contain as much as 3\% disseminated chalcopyrite and another may contain galena. Chemical analysis of these samples showed that only one contained any base metals: it was weakly anomalous in $\mathrm{Pb}$.

\section{Alteration:}

Age of mineralization:

\section{Deposit model:}

Kuroko massive sulfide (Cox and Singer, 1986; model 28a)

Deposit model number (After Cox and Singer, 1986 or Bliss, 1992): $28 \mathrm{a}$ 
Production Status: None

Site Status: Inactive

Workings/exploration:

The prospect was explored by geophysics and drilling in 1978 (Kurtak and others, 2002). Grybeck (1977, loc. 1) reported 77 lode claims located in 1975, and Dillon and others (1981) show a large claim block extending at least 10 miles east-west and 1 to 1.5 miles north-south.

\section{Production notes:}

Reserves:

Additional comments:

Core samples from three drill holes from the Roosevelt Creek and/or RO prospects are stored at the Alaska Geologic Materials Center in Eagle River, Alaska.

\section{References:}

Grybeck, 1977; Dillon and others, 1981 (AOF 133B) ; Arctic Environmental Information and Data Center, 1982; Maas, 1987; Nokleberg and others, 1987; Nokleberg and others, 1996; Kurtak and others, 2002.

Primary reference: Nokleberg and others, 1996

Reporter(s): J.M. Britton (Anchorage)

Last report date: $8 / 9 / 2002$ 


\section{Site name(s): Jones Creek (placer); Bog}

Site type: Occurrence

ARDF no.: WI135

Latitude: 67.1320

Quadrangle: WI A-6

Longitude: 152.5605

Location description and accuracy:

This placer occurrence is located on Jones Creek, an east tributary to lower Mettenpherg Creek. The occurrence is about 3 miles upstream of the mouth of Jones Creek in the SW 1/4 of section 26, T. 7 N., R. 23 W. of the Fairbanks Meridian. The location is accurate within 1 mile.

\section{Commodities:}

Main: $\mathrm{Au}$

Other:

Ore minerals: Gold

Gangue minerals: Garnet, magnetite

\section{Geologic description:}

Pan samples taken from two separate sites on lower Jones Creek (Kurtak and others, 2002) contained visible placer gold. Schist in the creek contained 1-2\% disseminated pyrite. Regional geologic mapping indicates the lower Jones Creek area is underlain by Devonian(?), quartz-mica schist, mica schist, phyllite, and quartzite (Brosge and Reiser, 1971). Placer claims were located on Jones Creek in 1976 (Kurtak and others, 2002).

\section{Alteration:}

Age of mineralization:

Quaternary.

\section{Deposit model:}

Placer Au (Cox and Singer, 1986; model 39a)

Deposit model number (After Cox and Singer, 1986 or Bliss, 1992):

$39 \mathrm{a}$

Production Status: None

Site Status: Probably inactive

Workings/exploration:

Placer claims were located on Jones Creek in 1976 (Kurtak and others, 2002).

Production notes:

Reserves:

Additional comments: 


\section{References:}

Maas, 1987; Brosge and Reiser, 1971; Kurtak and others, 2002.

Primary reference: Kurtak and others, 2002

Reporter(s): J.M. Britton (Anchorage)

Last report date: $8 / 9 / 2002$ 


\section{Site name(s): Red}

Site type: Occurrence

ARDF no.: WI136

Latitude: 67.1964

Quadrangle: WI A-6

Longitude: 152.7590

Location description and accuracy:

The Red property is located west of lower Mettenpherg Creek, about 5 to 6 miles north of the junction of Mettenpherg Creek and the Malamute Fork, Alatna River. Two small claim groups, approximately 1 to 1.5 miles apart in a north-south direction are shown by Dillon and others (1981, Plate 1 [AOF 133B]); the most northerly of these claim groups is inferred (from very scant data) to correspond to the Red property. The occurrence is near the center of the claim block at an elevation of about 2,150 feet, in the NE1/4 section 2, $\mathrm{T}$.

27 N., R. 24 W., of the Fairbanks Meridian. The location is accurate within 2 miles.

\section{Commodities:}

Main: $\mathrm{Cu}, \mathrm{Zn}$

Other:

Ore minerals:

Gangue minerals:

\section{Geologic description:}

Almost no information is available on this property. It reportedly is a stratiform $\mathrm{Cu}-\mathrm{Zn}$ occurrence in an area whose geology and geochemistry is similar to that in the Ambler District to the west (Grybeck, 1977 , loc. 2). The area is underlain by Middle(?) Devonian, calcareous schist interbedded with quartz mica schist and marble (Brosge and Reiser, 1971). The Bureau of Land Management made an aerial reconnaissance of the area in the 1990's, but saw nothing to suggest the presence of mineralization (Kurtak and others, 2002).

Twenty-one lode claims were staked in 1975 (Grybeck, 1977). Bureau of Land Management data indicate 8 claims were located in 1975 and abandoned in 1978 (Kurtak and others, 2002).

\section{Alteration:}

Age of mineralization:

Deposit model:

Kuroko massive sulfide(?) (Cox and Singer, 1986; model 28a)

Deposit model number (After Cox and Singer, 1986 or Bliss, 1992): $28 \mathrm{a}(?)$

Production Status: None

Site Status: Inactive

Workings/exploration:

Twenty-one lode claims were staked in 1975 (Grybeck, 1977). Bureau of Land Management data indicate 8 claims were located in 1975 and abandoned in 1978 (Kurtak and others, 2002). 
Production notes:

Reserves:

Additional comments:

See also Roosevelt Creek (WI134).

\section{References:}

Brosge and Reiser, 1971; Grybeck, 1977; Maas, 1987; Kurtak and others, 2002.

Primary reference: Grybeck, 1977

Reporter(s): J.M. Britton (Anchorage)

Last report date: $8 / 9 / 2002$ 


\section{Site name(s): Unnamed (lode near Jones Creek)}

Site type: Occurrence

ARDF no.: WI137

Latitude: 67.1496

Quadrangle: WI A-6

Longitude: 152.5951

Location description and accuracy:

The exact location of this lode occurrence is uncertain. It is probably at an elevation of about 1,100 feet on a north tributary to Jones Creek, in the SW1/4 section 22, T. 27 N., R. 23 W., of the Fairbanks Meridian. The coordinates are between two different locations given by Grybeck (1977) and Kurtak and others (2002).

Commodities:

Main: $\mathrm{Cu}, \mathrm{Zn}$

Other:

Ore minerals:

Gangue minerals:

Geologic description:

Almost no information is available on this property except that it reportedly is a stratiform $\mathrm{Cu}-\mathrm{Zn}$ occurrence in an area whose geology and geochemistry is similar to that in the Ambler District to the west (Grybeck, 1977, loc. 3). Regional geologic mapping indicates that the rocks in the vicinity of this occurrence are Devonian, Ambler metavolcanic rocks (Dillon and others, 1986).

Thirty-six lode claims were staked in 1975 (Grybeck, 1977) and 3 holes were drilled on the prospect in the 1970's by Anaconda Minerals.

Alteration:

Age of mineralization:

Deposit model:

Kuroko massive sulfide(?) (Cox and Singer, 1986; model 28a)

Deposit model number (After Cox and Singer, 1986 or Bliss, 1992):

$28 \mathrm{a}(?)$

Production Status: None

Site Status: Inactive

Workings/exploration:

Thirty-six lode claims were staked in 1975 (Grybeck, 1977) and 3 holes were drilled on the prospect in the 1970's by Anaconda Minerals.

Production notes:

Reserves: 
Additional comments:

Core samples from three drill holes from the Jones Creek prospect are stored at the Alaska Geologic Materials Center in Eagle River, Alaska.

See also: Roosevelt Creek (WI134).

\section{References:}

Grybeck, 1977; Dillon and others, 1986; Maas, 1987; Kurtak and others, 2002.

Primary reference: Grybeck, 1977

Reporter(s): J.M. Britton (Anchorage)

Last report date: 8/9/2002 


\section{Site name(s): Unnamed (west of Deadman Mountain)}

Site type: Occurrence

ARDF no.: WI138

Latitude: 67.0644

Quadrangle: WI A-6

Longitude: 152.9051

Location description and accuracy:

This occurrence is about 3 miles south-southeast of the junction of Roosevelt Creek and the Malamute Fork, Alatna River, and 5 miles west of Deadman Mountain. It is at an elevation of about 2,700 feet, about 0.3 mile northwest of hill 2850, in the NW1/4 section 20, T. 26 N., R. 24 W., of the Fairbanks Meridian. The occurrence is the site of sample 202 in Dillon and others (1981 [AOF 133B]). The location is accurate.

\section{Commodities:}

Main: $\mathrm{Ag}, \mathrm{Ba}$

Other:

Ore minerals:

\section{Gangue minerals:}

Geologic description:

This occurrence is based on an analysis of a rock sample of gray chert that contains 5 ppm silver and 5000 ppm barium (Dillon and others, 1981 [AOF 133B]). The rocks in the area are Devonian to Lower Jurassic, pillow basalt, diabase, chert and minor limestone (Dillon and others, 1986). No other information is available.

\section{Alteration:}

Age of mineralization:

Deposit model:

Deposit model number (After Cox and Singer, 1986 or Bliss, 1992):

Production Status: None

Site Status: Inactive

Workings/exploration:

Only surface sampling.

Production notes:

Reserves:

Additional comments:

References:

Dillon and others, 1981 (AOF 133B); Bliss and others, 1988. 
Primary reference: Dillon and others, 1981 (AOF 133B)

Reporter(s): J.M. Britton (Anchorage)

Last report date: $8 / 9 / 2002$ 


\section{Site name(s): Unnamed (west of upper Jones Creek)}

Site type: Occurrence

ARDF no.: WI139

Latitude: 67.1824

Quadrangle: WI A-6

Longitude: 152.5849

Location description and accuracy:

This occurrence is at an elevation of about 3,050 feet, about 0.6 mile north-northwest of hill 3065, on the ridge west of upper Jones Creek. It is in the northeast corner of section 10, T. 27 N., R. 23 W., of the Fairbanks Meridian. The occurrence is the site of sample 14 of Dillon and others (1981 [AOF 133B]). The location is accurate.

\section{Commodities:}

Main: Ba, Mo, V, Zn

Other:

Ore minerals:

\section{Gangue minerals:}

\section{Geologic description:}

This occurrence is a rock sample of black, graphitic, muscovite-albite-quartz schist that contains about $3 \%$ disseminated, oxidized, sulfides (Dillon and others, 1981 [AOF 133B]). A sample contains 3,000 ppm barium, $20 \mathrm{ppm}$ molybdenum, 1,000 ppm vanadium, and $430 \mathrm{ppm}$ zinc. The rocks in the area are interbedded Devonian, metavolcanic and metasedimentary rocks. No other information is available.

\section{Alteration:}

Oxidation of sulfide minerals.

Age of mineralization:

\section{Deposit model:}

Deposit model number (After Cox and Singer, 1986 or Bliss, 1992):

Production Status: None

Site Status: Inactive

Workings/exploration:

Only surface sampling.

Production notes:

Reserves:

Additional comments:

\section{References:}


Dillon and others, 1981 (AOF 133B); Bliss and others, 1988.

Primary reference: Dillon and others, 1981 (AOF 133B)

Reporter(s): J.M. Britton (Anchorage)

Last report date: $8 / 9 / 2002$ 


\section{Site name(s): Unnamed (head of Jones Creek tributary)}

Site type: Occurrence

ARDF no.: WI140

Latitude: 67.2110

Quadrangle: WI A-6

Longitude: 152.5929

Location description and accuracy:

This occurrence is at an elevation of about 3,200 feet at the head of a south-flowing tributary to Jones Creek. It is about 0.4 mile north-northeast of hill 3975, about 0.4 mile north-northeast of the center of section 34, T. 28 N., R. 23 W., of the Fairbanks Meridian. The occurrence is the site of sample 524 in Dillon and others (1981 [AOF 133B]). The location is accurate.

\section{Commodities:}

Main: $\mathrm{Cu}$

Other: $\mathrm{Ni}$

Ore minerals: Chalcopyrite

Gangue minerals:

Geologic description:

This occurrence consists of banded, gray and white, graphitic schist with about $1 \%$ disseminated chalcopyrite (Dillon and others, 1981 [AOF 133B]). Small gossans mark the outcrops. A rock sample contains 200 ppm nickel; no copper is reported. The rocks in the area are Proterozoic to lower Paleozoic(?) schist (Dillon and others, 1986).

\section{Alteration:}

Age of mineralization:

Deposit model:

Deposit model number (After Cox and Singer, 1986 or Bliss, 1992):

Production Status: None

Site Status: Inactive

Workings/exploration:

Only surface sampling.

Production notes:

Reserves:

Additional comments:

References:

Dillon and others, 1981 (AOF 133B); Dillon and others, 1986; Bliss and others, 1988. 
Primary reference: Dillon and others, 1981 (AOF 133B)

Reporter(s): J.M. Britton (Anchorage)

Last report date: $8 / 9 / 2002$ 


\section{Site name(s): Unnamed (northeast of Heart Mountain)}

Site type: Occurrence

ARDF no.: WI141

Latitude: 67.1035

Quadrangle: WI A-5

Longitude: 152.3013

Location description and accuracy:

This occurrence is located about 5 miles east-northeast of the summit of Heart Mountain. It is about 0.2 miles southwest of the center of section 1, T. 26 N., R. 22 W., of the Fairbanks Meridian. The occurrence is sample 78 in Dillon and others (1981 [AOF 133B]). The location is accurate.

\section{Commodities:}

Main: $\mathrm{Cu}$

Other: W

Ore minerals: Azurite, chalcopyrite

Gangue minerals:

Geologic description:

This occurrence consists of azurite and finely disseminated chalcopyrite in brown-green, aphanitic greenstone (Dillon and others, 1981 [AOF 133B]). A grab sample contains more than 50 ppm tungsten, but no copper. The area is underlain by Devonian to lower Jurassic, mafic volcanic rocks (Dillon and others, 1986).

Alteration:

Oxidation of copper mineral.

Age of mineralization:

Deposit model:

Deposit model number (After Cox and Singer, 1986 or Bliss, 1992):

Production Status: None

Site Status: Inactive

Workings/exploration:

Only surface sampling.

Production notes:

Reserves:

Additional comments:

References:

Dillon and others, 1981 (AOF 133B); Dillon and others, 1986; Bliss and others, 1988. 
Primary reference: Dillon and others, 1981 (AOF 133B)

Reporter(s): J.M. Britton (Anchorage)

Last report date: $8 / 9 / 2002$ 


\section{Site name(s): Unnamed (head of Bedrock Creek)}

Site type: Occurrence

ARDF no.: WI142

Latitude: 67.1861

Quadrangle: WI A-5

Longitude: 152.4309

Location description and accuracy:

This occurrence is near the head of Bedrock Creek about 7 miles north of Heart Mountain. It is at an elevation of about 3,300 feet just south of hill 3425, in the northwest corner of section 9, T. 27 N., R. 22 W., of the Fairbanks Meridian. The occurrence is sample 199 in Dillon and others (1981 [AOF 133B]). The location is accurate.

\section{Commodities:}

Main: $\mathrm{Pb}$

Other:

Ore minerals: Galena, pyrite(?)

Gangue minerals: Limonite

Geologic description:

This occurrence consists of galena, possibly pyrite, and limonite after pyrite, disseminated in epidotemuscovite-feldspar-quartz schist mapped as Ambler metavolcanic rocks (Dillon and others, 1986). A grab sample contains $150 \mathrm{ppm}$ lead (Dillon and others, 1981 [AOF 133B]. No other information is available.

Alteration:

Oxidation of pyrite(?).

Age of mineralization:

Deposit model:

Deposit model number (After Cox and Singer, 1986 or Bliss, 1992):

Production Status: None

Site Status: Inactive

Workings/exploration:

Only surface sampling.

Production notes:

Reserves:

Additional comments:

References:

Dillon and others, 1981 (AOF 133B); Dillon and others, 1986; Bliss and others, 1988. 
Primary reference: Dillon and others, 1981 (AOF 133B)

Reporter(s): J.M. Britton (Anchorage)

Last report date: 8/9/2002 


\section{Site name(s): Unnamed (northwest of Gilroy Mountain)}

Site type: Occurrence

ARDF no.: WI143

Latitude: 67.2451

Quadrangle: WI A-4

Longitude: 151.5814

Location description and accuracy:

This occurrence is at an elevation of about 3,300 feet about 2.0 miles west-northwest of the top of Gilroy Mountain. The site corresponds to the location of samples 50 and 51 in Dillon and others (1981). The location is accurate.

\section{Commodities:}

Main: $\mathrm{Ag}, \mathrm{As}, \mathrm{Au}$

Other: $\mathrm{Bi}, \mathrm{Cu}, \mathrm{Sb}, \mathrm{Zn}$

Ore minerals: Arsenopyrite, chalcopyrite, sphalerite

Gangue minerals:

Geologic description:

This occurrence consist of a stockworks of small sulfide veins in marble (Dillon and others, 1981 [AOF 133B]). They collected two grab samples. A fine-grained actinolite marble contains narrow veins of chalcopyrite and sphalerite; a gray marble contains veins of arsenopyrite, sphalerite, and traces of chalcopyrite. The arsenopyrite veins were as much as $10 \mathrm{~cm}$ thick. The arsenopyrite-bearing sample contains $10 \mathrm{ppm}$ silver, $10 \%$ arsenic, $15 \mathrm{ppm}$ gold, $50 \mathrm{ppm}$ bismuth, and $300 \mathrm{ppm}$ antimony. The other sample contained no anomalous metal values. The rocks in the area are mainly Devonian, Ambler metavolcanic rocks (Dillon and others, 1986).

\section{Alteration:}

Age of mineralization:

\section{Deposit model:}

Polymetallic vein(?) (Cox and Singer, 1986; model 22c)

Deposit model number (After Cox and Singer, 1986 or Bliss, 1992): $22 \mathrm{c}(?)$

Production Status: None

Site Status: Inactive

Workings/exploration:

Only surface sampling.

Production notes:

Reserves: 
Additional comments:

\section{References:}

Dillon and others, 1981 (AOF 133B); Bliss and others, 1988.

Primary reference: Dillon and others, 1981 (AOF 133B)

Reporter(s): J.M. Britton (Anchorage)

Last report date: $8 / 9 / 2002$ 


\section{Site name(s): Timber Creek}

Site type: Occurrences

ARDF no.: WI144

Latitude: 67.0680

Quadrangle: WI A-4

Longitude: 151.8329

Location description and accuracy:

Timber Creek is a large, south-lowing stream which joins the John River west of Ninemile Hills. The locations of placer occurrences on Timber Creek are not described in detail. The site is arbitrarily placed about three-quarters of a mile north of the mouth of the creek.

\section{Commodities:}

Main: $\mathrm{Au}$

Other:

Ore minerals: Gold

Gangue minerals:

Geologic description:

Although Reed (1938) did not visit Timber Creek, he noted local reports that the creek was auriferous. According to Reed (1938), in the early 1900's no claims were allowed on the creek by popular agreement and the creek was reserved for men who had not made enough money during the first half of the summer to get them through the winter. Reed related that the gold was recovered from the bars of the stream by rocking and that a man could recover $\$ 4$ per day (gold at $\$ 35 /$ ounce). There is no other record of mining on this creek.

\section{Alteration:}

Age of mineralization:

Quaternary.

Deposit model:

Placer Au (Cox and Singer, 1986; model 39a)

Deposit model number (After Cox and Singer, 1986 or Bliss, 1992):

$39 \mathrm{a}$

Production Status: Undetermined.

Site Status: Inactive

Workings/exploration:

About \$4/day in gold could be recovered from the bars of the stream using a rocker (Reed, 1938).

Production notes:

Reserves: 
Additional comments:

\section{References:}

Reed, 1938; Cobb, 1976 (OF76-340); Cobb, 1981 (OF81-732).

Primary reference: Reed, 1938

Reporter(s): J.M. Britton (Anchorage)

Last report date: $8 / 9 / 2002$ 


\section{Site name(s): Suckik Creek; Sickik Creek}

Site type: Mine

ARDF no.: WI145

Latitude: 67.1970

Quadrangle: WI A-4

Longitude: 151.7512

Location description and accuracy:

Suckik Creek (Sickik Creek on the modern (1970) A-4 topographic map and Suckik Creek on the 1:250,000 map) is south-flowing tributary to Timber Creek. The mouth of Suckik Creek is directly across Timber Creek from Button Mountain. There is no information as to the exact location of prior mining on the creek. The site is arbitrarily placed about a mile upstream from its mouth.

\section{Commodities:}

Main: $\mathrm{Au}$

Other:

Ore minerals: Gold

\section{Gangue minerals:}

Geologic description:

The only information about placer mining on Suckik Creek is a reference to a 2-man mining operation in 1948 that included shoveling-in and prospecting (Stewart, 1949). The area of Suckik Creek is predominantly underlain by Proterozoic or lower Paleozoic(?) schist and local marble, and by smaller areas of Devonian, Ambler metavolcanic rocks (Dillon and others, 1986).

\section{Alteration:}

Age of mineralization:

Quaternary.

\section{Deposit model:}

Placer Au (Cox and Singer, 1986; model 39a)

Deposit model number (After Cox and Singer, 1986 or Bliss, 1992):

$39 \mathrm{a}$

Production Status: Yes

Site Status: Inactive

Workings/exploration:

There are reports of mining and prospecting in 1948 (Stewart, 1949).

Production notes:

Reserves:

Additional comments: 


\section{References:}

Stewart, 1949; Maas, 1987; Kurtak and others, 2002.

Primary reference: Stewart, 1949

Reporter(s): J.M. Britton (Anchorage)

Last report date: $8 / 9 / 2002$ 


\section{Site name(s): Smally Creek; Smalley Creek}

Site type: Mine

ARDF no.: WI146

Latitude: 67.0200

Quadrangle: WI A-2

Longitude: 150.5780

Location description and accuracy:

Smally Creek, a northwest-flowing headwater tributary of John R Creek, is about 4.8 miles southwest of Tramway Bar. The mine is plotted about 1,000 feet upstream of the mouth of Smally Creek, where placer mining is said to have taken place in the early 1900's (Reed, 1938). The location is accurate within threequarters of a mile.

\section{Commodities:}

Main: $\mathrm{Au}$

Other:

Ore minerals: Gold

\section{Gangue minerals:}

\section{Geologic description:}

Placer gold on Smally Creek occurs in the modern stream bed. The alluvium is about 17 feet thick. The upper 4 to 7 feet consists of muck, and the remainder is coarse and waterworn gravel with numerous boulders. The gold occurs principally on bedrock, but also in the lower 6 feet of the gravel. The gold forms very fine, flat flakes; there are infrequent coarse pieces. Reed (1938) noted that the average fineness of the gold was 907. The fineness of five samples of gold from Smally Creek collected around 1985 varies from 853 to 933 (Mosier and Lewis, 1986). The bedrock on Smally Creek is black shale and quartz conglomerate; Reed (1938) suspects that the conglomerate was the source of the fine gold in the placer.

The placer was mined in the early 1900's. Reed (1938) reports mining by ground sluicing and shoveling in in 1937, and notes that there were plans for hydraulic and/or mechanized mining. Numerous claims were active in the vicinity in the early 1980 's.

\section{Alteration:}

Age of mineralization:

Quaternary.

Deposit model:

Placer Au (Cox and Singer, 1986; model 39a)

Deposit model number (After Cox and Singer, 1986 or Bliss, 1992): $39 \mathrm{a}$

Production Status: Yes

Site Status: Inactive

Workings/exploration:

The placer was mined in the early 1900's. Reed (1938) reports mining by ground sluicing and shoveling 
in in 1937, and notes that there were plans for hydraulic and/or mechanized mining. Numerous claims were active in the vicinity in the early 1980's.

Production notes:

Reserves:

Probably some minor placer gold production.

Additional comments:

References:

Reed, 1938; Cobb, 1972 (MF-469); Cobb, 1976 (OF76-340); Cobb, 1981 (OF81-732); Mosier and Lewis, 1986; Maas, 1987; Bliss and others, 1988.

Primary reference: Reed, 1938

Reporter(s): J.M. Britton (Anchorage)

Last report date: $8 / 9 / 2002$ 


\section{Site name(s): Twelvemile Creek (includes forks of Twelvemile Creek; Po- tato Creek)}

Site type: Mine

ARDF no.: WI147

Latitude: 67.2015

Quadrangle: WI A-1

Longitude: 150.4961

Location description and accuracy:

Twelvemile Creek is a large western tributary to the Middle Fork, Koyukuk River. The junction of Twelvemile Creek and the Middle Fork is about 6.5 miles southwest of Coldfoot. The locations of the placer gold deposits along Twelvemile Creek are not clearly defined. Placers apparently occur intermittently along the creek from a point beginning near its mouth, extend upstream along Twelvemile Creek, and then continues up the Upper Fork (probably called Middle Fork by Reed, 1938) for an undetermined distance. The coordinates are at the junction of Upper Fork and Twelvemile Creek.

\section{Commodities:}

Main: $\mathrm{Au}$

Other:

Ore minerals: Gold

Gangue minerals:

\section{Geologic description:}

Reed (1938) states that Twelvemile Creek contains placer deposits in the modern channel, in a deep channel, and in high bench channels. Reed's descriptions of mining and prospecting efforts suggest that the gold in the deposits is sporadically distributed. The depth to bedrock in the modern channel of Twelvemile Creek (in areas that are not coincident with the deep channel) is about 5 feet. The gold-bearing gravels on the lower parts of the modern channel are relatively fine with few boulders. Those on the upper parts contain more boulders.

There are two high-bench channels, an upper one, called 'primary', and a lower one, called 'secondary'. The secondary bench is about 60 feet wide and 20 feet above the modern stream; it occurs only along the left limit of the Upper Fork (the Middle Fork of Reed, 1938). The primary bench is about 125 feet above the secondary. It is 600 feet wide, and lies along the left limit of lower Upper Fork and along Twelvemile Creek downstream as far as the Lower Fork (the North Fork of Reed, 1938). Below Lower Fork, high channels occur along the right limit of Twelvemile Creek at about the same level as the primary bench. An adit into the primary channel on the lower Upper Fork explored gravels containing gold values of $\$ 0.75$ per cubic yard (gold at \$35 per ounce). Although a deep channel is apparently present along Twelvemile Creek it isn't clear whether it contains any gold.

Reed (1938) reported only one active mining operation in 1937, along lower Upper Fork (Middle Fork). The depth to bedrock at that location was 8 to 21 feet, and very fine, flat pieces of gold were distributed throughout the gravel. The values were about $\$ 0.35$ per square foot of bedrock and the average fineness was 914.

According to Reed (1938), several other tributaries of Twelvemile Creek, including West Fork (West Fork and South Fork join to form Twelvemile Creek), North Fork (probably the Lower Fork on modern topographic map), and Potato Creek (a small left limit tributary about a mile below Upper Fork) have been explored and/or mined with varying degrees of success.

The bedrock in the Twelvemile Creek area is mainly graphitic and quartz schist (Reed, 1938). Dillon and others (1986) mapped it as Mississippian to Triassic metagraywacke and phyllite, and upper Devonian, 
Hunt Fork schist.

From about 1900 to 1910 , the modern creek bed was mined by hand methods. Later mining included shafts, open cuts, and drifting (Reed, 1938) There was exploration drilling in 1934 and hydraulic mining in 1937 (Reed, 1938). Some exploration work was conducted on the south fork of Twelvemile Creek in 1986.

\section{Alteration:}

\section{Age of mineralization:}

Quaternary.

\section{Deposit model:}

Placer Au (Cox and Singer, 1986; model 39a)

Deposit model number (After Cox and Singer, 1986 or Bliss, 1992):

$39 \mathrm{a}$

Production Status: Yes

Site Status: Inactive

\section{Workings/exploration:}

From about 1900 to 1910 , the modern creek bed was mined by hand methods. Later mining included shafts, open cuts, and drifting (Reed, 1938) There was exploration drilling in 1934 and hydraulic mining in 1937 (Reed, 1938). Some exploration work was conducted on the south fork of Twelvemile Creek in 1986.

\section{Production notes:}

Maddren (1913) reported a total production of $\$ 5,000$ of gold (about 260 ounces), mostly in 1900 and 1901.

\section{Reserves:}

\section{Additional comments:}

\section{References:}

Schrader, 1900; Schrader, 1904; Maddren, 1910; Maddren, 1913; Wimmler, 1925; Smith, 1936; Smith, 1937; Reed, 1938; Heiner and Wolff, 1968; Cobb, 1972 (MF-469); Mulligan, 1974; Cobb, 1976 (OF76340); Orris and Bliss, 1985; Bundtzen and others, 1987; Maas, 1987; Bliss and others, 1988.

Primary reference: Reed, 1938

Reporter(s): J.M. Britton (Anchorage)

Last report date: 8/9/2002 


\section{Site name(s): Eagle Cliff; Eagle Bluff}

Site type: Mine

ARDF no.: WI148

Latitude: 67.0492

Quadrangle: WI A-1

Longitude: 150.0638

Location description and accuracy:

The Eagle Cliff placer mine is on the north bank of the South Fork, Koyukuk River, about 12 miles eastsoutheast of Tramway Bar. The mine is near the west end of Eagle Cliff, a geographic feature shown on the Wiseman A-1 topographic map (1975 ed.) in sections 29 \& 30, T. 26N., R. 11W., of the Fairbanks Meridian. The extent of the placer is uncertain but it may extend a mile or so to the east along the valley floor at the base of the Eagle Cliff bluff. The location is accurate to within 1 mile.

\section{Commodities:}

Main: $\mathrm{Au}$

Other:

Ore minerals: Gold

\section{Gangue minerals:}

\section{Geologic description:}

Gold in coarse, wheat-sized rounded grains, was mined from well-washed gravel on top of a bench cut into rock about 10-12 feet above the low-water level of the South Fork Koyukuk River (Maddren, 1913). Reed (1938) noted that Eagle Bluff was said to be a high channel that resembled the Ironside Bench and Gold Bench placers (both in the Bettles quadrangle) about 15-20 miles downstream.

A waterwheel was used to raise water to work the placer in 1899 (Schrader, 1900). Four or five men worked the placer in 1910. Reed (1938) noted that no one was working the site in 1937, although there were plans to work there in 1938. Maddren (1913) noted that $\$ 1,000$ in gold was produced from 1900 to 1909 , and an additional \$1,500 in gold was produced in 1910 .

\section{Alteration:}

Age of mineralization:

Quaternary.

Deposit model:

Placer Au (Cox and Singer, 1986; model 39a)

Deposit model number (After Cox and Singer, 1986 or Bliss, 1992): $39 \mathrm{a}$

Production Status: Yes; small

Site Status: Probably inactive

Workings/exploration:

A waterwheel was used to raise water to work the placer in 1899 (Schrader, 1900). Four or five men worked the placer in 1910. Reed (1938) noted that no one was working the site in 1937, although there were 
plans to work there in 1938.

\section{Production notes:}

Maddren (1913) noted that $\$ 1,000$ in gold was produced from 1900 to 1909 , and an additional $\$ 1,500$ in gold was produced in 1910 .

\section{Reserves:}

\section{Additional comments:}

\section{References:}

Schrader, 1904; Maddren, 1910; Maddren, 1913; Reed, 1938; Heiner and Wolff, 1968; Cobb, 1972 (MF469); Cobb, 1976 (OF76-340); Cobb, 1977 (OF77-168B); Maas, 1987; Bliss and others, 1988.

Primary reference: Maddren, 1913

Reporter(s): J.M. Britton (Anchorage)

Last report date: $8 / 9 / 2002$ 


\section{Site name(s): Slate Creek}

Site type: Mine

ARDF no.: WI149

Latitude: 67.2199

Quadrangle: WI A-1

Longitude: 150.0341

Location description and accuracy:

Slate Creek is a west-flowing tributary to the Middle Fork,Koyukuk River. The coordinates are for a site immediately downstream from the junction of Slate Creek and Myrtle Creeks. Mining on Slate Creek in the Wiseman quadrangle probably extended from near the mouth upstream to the junction with Myrtle Creek, a distance of about 7 or 8 miles. There was also mining activity on upper Slate Creek, above its junction with Myrtle Creek in the Chandalar quadrangle.

\section{Commodities:}

Main: $\mathrm{Au}$

Other:

Ore minerals: Gold

\section{Gangue minerals:}

\section{Geologic description:}

The gold in Slate Creek occurs in the modern channel and in high channels both above and below the junction with Myrtle Creek (Reed, 1938). In the modern channel from the mouth of Slate Creek upstream to the junction with Myrtle Creek, the gravels are 10 to 40 feet thick. Reed (1938) indicates that it was possible for the early miners to recover $\$ 3$ to $\$ 4$ per day of flour gold (approx. 0.15 - 0.20 ounce of gold) by rocking. The high channels along Slate Creek were prospected in the early 1900's, but they contained insufficient gold to justify mining. The productive portion of Slate Creek above the junction with Myrtle Creek is probably in the adjoining Chandalar quadrangle. Bedrock along Slate Creek is mica schist, slate, or phyllite containing small bodies of quartz and cut by several altered diorite dikes (Maddren, 1913).

Slate Creek was mined by hand and by mechanized methods including use of a dragline (Bliss and others, 1988). There was some scattered exploration drilling. Intermittent mining continued up through at least 1993 (Bundtzen and others, 1994). Maddren (1913) reported production of \$3,000 (about 150 ounces of gold) from 1900 to 1909 . No information is available for later production.

\section{Alteration:}

Age of mineralization:

Quaternary.

\section{Deposit model:}

Placer Au (Cox and Singer, 1986; model 39a)

Deposit model number (After Cox and Singer, 1986 or Bliss, 1992): $39 \mathrm{a}$

Production Status: Yes

Site Status: Probably inactive 


\section{Workings/exploration:}

Slate Creek was mined by hand and by mechanized methods including use of a dragline (Bliss and others, 1988). There was some scattered exploration drilling. Intermittent mining continued up through at least 1993 (Bundtzen and others, 1994).

\section{Production notes:}

Maddren (1913) reported production of \$3,000 (about 150 ounces of gold) from 1900 to 1909. No information is available for later production.

\section{Reserves:}

Additional comments:

See also Myrtle Creek (WI150) and Slate Creek (in the Chandalar quadrangle).

\section{References:}

Schrader, 1900; Schrader, 1904; Maddren, 1910; Maddren, 1913; Wimmler, 1925; Reed, 1938; Smith, 1939 (B910A); Smith, 1939 (B917A); Smith, 1941; Cobb, 1972 (MF-469); Cobb, 1976 (OF76-340); Cobb, 1977 (OF77-168B); Cobb, 1981 (OF81-732); Eakins and others, 1985; Maas, 1987; Bliss and others, 1988; Bundtzen and others, 1994; Swainbank and others, 1995; Britton, 2000.

Primary reference: Reed, 1938

Reporter(s): J.M. Britton (Anchorage)

Last report date: $8 / 9 / 2002$ 


\section{Site name(s): Myrtle Creek}

Site type: Mine

ARDF no.: WI150

Latitude: 67.2523

Quadrangle: WI A-1

Longitude: 150.3119

Location description and accuracy:

Myrtle Creek is a south-flowing tributary to Slate Creek. Only about the lower 1.5 mile of the creek is in the Wiseman quadrangle; the remaining portion is in the Chandalar quadrangle to the east. The mouth of Myrtle Creek is approximately 5 miles southeast of Coldfoot. Myrtle Creek reportedly has been placer mined for approximately six miles above its mouth. For this record, the location is plotted on Myrtle Creek about 0.5 mile upstream from its mouth. The location is accurate within one-half mile.

\section{Commodities:}

Main: $\mathrm{Au}$

Other:

Ore minerals: Gold

\section{Gangue minerals:}

\section{Geologic description:}

Gold was discovered in 1899 on Myrtle Creek about 2 1/2 miles above its mouth (Maddren, 1913). The most productive ground was 2 to 3 miles above the mouth (in the Chandalar quadrangle). The gold occurs in gravels in the modern channel and in bench gravels along the lower 2 to 3 miles of the creek. According to Maddren (1913), the width of the gravels in the modern channel is 100 to 300 feet . Reed (1938), however, puts the width at 30-150 feet. The gold was distributed throughout the modern stream gravels. The gravels averaged 2 to 4 feet thick but may be as much as 7 feet thick. Maddren (1913) described the gold as 'shot' or 'wheat' (sized) gold, although he speculated that much of the fine gold was not being recovered at the time. The gold was coarse, clean, and somewhat flattened (like melon seeds) and included occasional nuggets up to about 1 ounce. Smith (1942) reports recovery of a 23-ounce nugget. The gold generally is concentrated on schist bedrock and in crevices in the bedrock as much as 3 feet below the gravel/bedrock contact.

Reed (1938) reports active mining in 1937 both on the modern channel and on benches. In at least two locations, Reed described the gold as both fine and flaky and coarse and well-worn. At one of these locations, a bench about 2 3/4 miles from the mouth, Reed noted that the fine and flaky gold was present throughout the gravel; coarser, worn gold (with occasional small nuggets) was on or in the top 3 feet of, bedrock. The gravel consist mainly of slabby schist with varying numbers of greenstone boulders. The bedrock is graphitic to siliceous and slate, that is cut by at least one greenstone dike (Reed, 1938).

Mining began on Myrtle Creek in 1899 (Schrader, 1900). Mining in the early days was by open cut and later by drifting, principally on the benches. Hydraulicking was begun in 1909. Nearly all evidence of the early mining had disappeared by 1937 (Reed, 1938). Mining using a dragline and bulldozers began in 1940 and continued at least into the early 1950's (Heiner and Wolff, (1968); Cobb, 1973 [B1374]). The gravels are thawed near the modern channel but frozen near the benches. Gold from three locations along the creek was 886 fine at one location and 914 fine at the other two (Reed, 1938). There was exploration activity in 1984 (Eakins and others, 1985) and development activity as late as 1992 (Swainbank and others, 1993).

Myrtle Creek (in both the Wiseman and Chandalar quadrangles) has been one of the largest placer gold producers in the Koyukuk district. The following values reflect gold prices at the time of the early reports. The total production is not known but production through 1910 was estimated by Maddren (1913) to be $\$ 182,000$ (about 9,000 ounces). Reed (1938) reported that at least $\$ 20,000$ was mined in the early days 
(1900-1910?) from a short section above Kelly's Pup in one summer. Values reported by Reed (1938) ranged from $\$ 0.35$ to $\$ 1.20$ per square foot of bedrock. The most productive part of the stream was reported by Maddren (1913) to be at the mountain front, 2 to 3 miles above the mouth of Myrtle Creek. While the creek has been worked from the mouth up to claim No. 20 Above, the claims along the creek above No. 15 were not profitable. Mining continued sporadically from 1899 until at least 1998 (Kurtak and others, 2002). The most recent production was in 1995 (Bundtzen and others, 1996).

\section{Alteration:}

Age of mineralization:

Quaternary.

Deposit model:

Placer Au (Cox and Singer, 1986; model 39a)

\section{Deposit model number (After Cox and Singer, 1986 or Bliss, 1992):} $39 \mathrm{a}$

Production Status: Yes; small

Site Status: Inactive

\section{Workings/exploration:}

Mining began on Myrtle Creek in 1899 (Schrader, 1900). Mining in the early days was by open cut and later by drifting, principally on the benches. Hydraulicking was begun in 1909. Nearly all evidence of the early mining had disappeared by 1937 (Reed, 1938). Mining using a dragline and bulldozers began in 1940 and continued at least into the early 1950's (Heiner and Wolff, (1968); Cobb, 1973 [B1374]). The gravels are thawed near the modern channel but frozen near the benches. Gold from three locations along the creek was 886 fine at one location and 914 fine at the other two (Reed, 1938). There was exploration activity in 1984 (Eakins and others, 1985) and development activity as late as 1992 (Swainbank and others, 1993).

\section{Production notes:}

Myrtle Creek (in both the Wiseman and Chandalar quadrangles) has been one of the largest placer gold producers in the Koyukuk district. The following values reflect gold prices at the time of the early reports. The total production is not known but production through 1910 was estimated by Maddren (1913) to be $\$ 182,000$ (about 9,000 ounces). Reed (1938) reported that at least $\$ 20,000$ was mined in the early days (1900-1910?) from a short section above Kelly's Pup in one summer. Values reported by Reed (1938) ranged from $\$ 0.35$ to $\$ 1.20$ per square foot of bedrock. The most productive part of the stream was reported by Maddren (1913) to be at the mountain front, 2 to 3 miles above the mouth of Myrtle Creek. While the creek has been worked from the mouth up to claim No. 20 Above, the claims along the creek above No. 15 were not profitable. Mining continued sporadically from 1899 until at least 1998 (Kurtak and others, 2002). The most recent production was in 1995 (Bundtzen and others, 1996).

\section{Reserves:}

\section{Additional comments:}

\section{References:}

Schrader, 1900; Schrader, 1904; Brooks, 1908; Maddren, 1910; Maddren, 1913; Brooks, 1915; Brooks, 1916; Smith, 1917 (BMB 153); Brooks, 1918; Brooks, 1922; Smith, 1930 (B810); Smith, 1932; Smith, 1933 (B836); Smith, 1936; Smith, 1937; Reed, 1938; Smith, 1938; Smith, 1939 (B910A); Smith, 1939 (B917A); Smith, 1941; Smith, 1942; Roehm, 1949; Holdsworth, 1952; Holdsworth, 1957; Heiner and Wolff, 1968; Cobb, 1972 (MF-469); Cobb, 1973 (B1374); Mulligan, 1974; Cobb, 1976 (OF76-340); Grybeck, 1977; U.S. Bureau of Mines, 1978; Eakins and others, 1985; Maas, 1987; Bliss and others, 1988; Bundtzen and others, 1992; Swainbank and others, 1993; Bundtzen and others, 1996. 
Primary reference: Reed, 1938

Reporter(s): J.M. Britton (Anchorage)

Last report date: $8 / 9 / 2002$ 


\section{Site name(s): Rosie Creek; Rose Creek; Lake Creek}

Site type: Prospects

ARDF no.: WI151

Latitude: 67.1949

Quadrangle: WI A-1

Longitude: 150.1890

Location description and accuracy:

Rosie Creek flows north from Rosie Creek Pass, along the east side of Cathedral Mountain. The creek turns west along its lower course, and enters the Middle Fork, Koyukuk River about 2 miles northeast of the mouth of Twelvemile Creek. About 3 miles east of its mouth, Rosie Creek is joined by an unnamed (on the A-1 topographic map) southerly-flowing tributary called Lake Creek by Reed (1938). The coordinates are at the junction of Rosie Creek and Lake Creek. Prospects are located on Lake Creek upstream for a distance of about 2 miles, and downstream on Rosie Creek for about a mile. The location is accurate within one mile.

\section{Commodities:}

Main: $\mathrm{Au}$

Other:

Ore minerals: Gold

\section{Gangue minerals:}

Geologic description:

A number of prospect shafts were sunk in the early 1900's on Rosie Creek and its tributary Lake Creek (Reed, 1938). The depth to bedrock varies from just over 100 feet to as much as 275 feet in one shaft near the head of Lake Creek. Maddren (1913) reported fine gold in surface gravels about 2 miles above the mouth of Rose(sic) Creek, and that a 113-foot shaft near the junction of Rose Creek and Lake Creek worked a thin layer of gravel on bedrock that produced numerous fine flakes of gold. Reed (1938) described several additional shafts from near the head of Lake Creek to about 0.2 mile below the junction of Rosie and Lake Creeks. Only the shafts on Lake Creek found any gold. This was fine flour gold, which occurred throughout the gravels from a depth of 20 feet to the top of the bedrock. Reed (1938) reported that the bedrock on Rosie Creek is greenstone and the bedrock on Lake Creek is schist. According to Dillon and others (1986), Rosie Creek is underlain by metagraywacke and phyllite, and upper Lake Creek is underlain by schist of the Hunt Fork Formation.

\section{Alteration:}

Age of mineralization:

Quaternary.

\section{Deposit model:}

Placer Au (Cox and Singer, 1986; model 39a)

Deposit model number (After Cox and Singer, 1986 or Bliss, 1992): $39 a$

Production Status: None

Site Status: Inactive 
Workings/exploration:

Prospect shafts.

Production notes:

Reserves:

Additional comments:

References:

Maddren, 1913; Reed, 1938; Heiner and Wolff, 1968; Cobb, 1973 (B1374); Cobb, 1976 (OF76-340); Cobb, 1981 (OF81-732); Maas, 1987.

Primary reference: Reed, 1938

Reporter(s): J.M. Britton (Anchorage)

Last report date: $8 / 9 / 2002$ 


\section{Site name(s): Porcupine Creek}

Site type: Mine

ARDF no.: WI152

Latitude: 67.2468

Quadrangle: WI A-1

Longitude: 150.3005

Location description and accuracy:

Porcupine Creek is a south-flowing tributary to the Middle Fork, Koyukuk River. It flows into the Middle Fork about 3 miles southwest of Coldfoot and 7 miles northeast of Twelvemile Mountain. The mine is on Porcupine Creek just below the junction with Quartz Creek. Placer mining has occurred from 3 miles above to perhaps 1.25 miles below the junction with Quartz Creek. The location is accurate within one-half mile.

\section{Commodities:}

Main: $\mathrm{Au}$

Other:

Ore minerals: Gold

\section{Gangue minerals:}

Geologic description:

Placer gold mining on Porcupine Creek was first reported in 1901 when Maddren (1913) noted that four men were producing $\$ 8$ per man per day. The placer gold on Porcupine Creek occurs both in the modern channel and in a deep channel. Reed (1938) reported mining on the modern channel for a distance of 600 feet below and 3 miles above the mouth of Quartz Creek. Below Quartz Creek, Porcupine Creek was mined from 1916 until the time of Reed's visit in 1937. Below Quartz Creek, the depth to bedrock was 6 feet in the modern creek bed and deepened to about 30 feet as the workings moved toward the left limit of the creek. The gravel was frozen and consisted of small worn pieces of schist mixed with coarse sand and many large boulders. The gold occurs in the lower 3 to 6 feet of the gravel, but only a little gold was on bedrock. The gold is generally fairly fine with an occasional nugget, and had a fineness of 854 . The value of the ground (in 1938) was about $\$ 0.59$ per square foot of bedrock.

Reed (1938) described workings in a 20 to 25 -foot-wide, deep channel about 30 feet below the surface. Although the overlying material was frozen, the deep channel itself was not. Reed reports that the value of the ground was $\$ 0.67$ per square foot of bedrock.

Early mining of the modern channel was by ground sluicing and shoveling in; the deep channel was drift mined. There are reports of mining into the 1980's using a dozer (Bundtzen and others, 1984). Mining was reported on the creek in 2000 (Kurtak and others, 2002).

\section{Alteration:}

\section{Age of mineralization:}

Quaternary.

\section{Deposit model:}

Placer Au (Cox and Singer, 1986; model 39a)

Deposit model number (After Cox and Singer, 1986 or Bliss, 1992):

$39 \mathrm{a}$ 
Production Status: Yes; small

Site Status: Active

Workings/exploration:

Early mining of the modern channel was by ground sluicing and shoveling in; the deep channel was drift mined. There are reports of mining into the 1980's using a dozer (Bundtzen and others, 1984). Mining was reported on the creek in 2000 (Kurtak and others, 2002).

\section{Production notes:}

Maddren (1913) reported \$2,000 of gold (approximately 105 ounces) was produced in 1900 and 1901. Bliss and others (1988) reported a total production of about 240 ounces. Heiner and Wolff (1968) indicate a total production from Porcupine Creek of as much as $\$ 100,000$, but this figure is questionable.

\section{Reserves:}

Additional comments:

See also Quartz Creek (WI126).

\section{References:}

Schrader, 1900; Schrader, 1904; Maddren, 1910; Maddren, 1913; Brooks, 1918; Wimmler, 1925; Smith, 1930 (B810); Smith, 1932; Smith, 1933 (B836); Smith, 1936; Smith, 1937; Reed, 1938; Smith, 1938; Saunders, 1954; Brosge and Reiser, 1960; Heiner and Wolff, 1968; Cobb, 1972 (MF-469); Cobb, 1973 (B1374); Mulligan, 1974; Carnes, 1976; ; Cobb, 1976 (OF76-340); Eakins and others, 1983; Bundtzen and others, 1984; Mosier and Lewis, 1986; Dillon, 1987; Maas, 1987; Bliss and others, 1988; Kurtak and others, 2002.

Primary reference: Reed, 1938

Reporter(s): J.M. Britton (Anchorage)

Last report date: $8 / 9 / 2002$ 


\section{Site name(s): Grubstake Bar}

Site type: Mine

ARDF no.: WI153

Latitude: 67.0108

Quadrangle: WI A-1

Longitude: 150.4325

Location description and accuracy:

Grubstake Bar is described by Reed (1938) as being on the right limit of the South Fork, Koyukuk River about 2 miles above Hanshaw Bar (WI155) which is about 5.8 miles by river above Gold Bench (in the Bettles quadrangle). Maddren (1913) described the occurrence on the NW bank of South Fork about 9 miles above Gold Bench. The site is here plotted on a sand bar on the north bank of the South Fork, opposite the mouth of Bear Creek, in the northwest corner of section 9, T. 25 N., R. 13 W., of the Fairbanks Meridian. The location is accurate within one mile.

\section{Commodities:}

Main: $\mathrm{Au}$

Other:

Ore minerals: Gold

Gangue minerals:

Geologic description:

Maddren (1913) described Grubstake Bar as a low-bench deposit. Reed (1938) described it as a superficial deposit in the present river channel, similar to Hanshaw Bar (WI155).

\section{Alteration:}

Age of mineralization:

Quaternary.

\section{Deposit model:}

Placer Au (Cox and Singer, 1986; model 39a)

Deposit model number (After Cox and Singer, 1986 or Bliss, 1992):

$39 \mathrm{a}$

Production Status: Yes; small

Site Status: Inactive

Workings/exploration:

Maddren (1913) reported that the deposit had been worked with sluice boxes in 1900-1901.

Production notes:

About $\$ 4,000$ in gold (about 200 ounces) was produced from 1900 to 1909 (Maddren, 1913).

Reserves: 
Additional comments:

\section{References:}

Maddren, 1910; Maddren, 1913; Reed, 1938; Heiner and Wolff, 1968; Cobb, 1972 (MF-469); Cobb, 1973

(B1374); Cobb, 1976 (OF76-340); Eakins and others, 1985; Bundtzen and others, 1986; Bliss and others, 1988.

Primary reference: Maddren, 1913

Reporter(s): J.M. Britton (Anchorage)

Last report date: $8 / 9 / 2002$ 


\section{Site name(s): Chapman Creek}

Site type: Occurrence

ARDF no.: WI154

Latitude: 67.0929

Quadrangle: WI A-1

Longitude: 150.4826

Location description and accuracy:

Chapman Creek is a west-flowing tributary to the Middle Fork, Koyukuk River about 4 miles south of Twelvemile Mountain. Chapman Creek enters the Middle Fork at Chapman Island about 1/2 mile upstream from Tramway Bar (WI156). The coordinates are for a location about a mile upstream from the mouth of Chapman Creek, about midway along the workings. The location is accurate within one-half mile.

\section{Commodities:}

Main: $\mathrm{Au}$

Other:

Ore minerals: Gold

\section{Gangue minerals:}

Geologic description:

Gold was found in shafts sunk in 1908-09 along a stretch of Chapman Creek 1/4 to 1 mile above its mouth (Maddren, 1913). The workings included thirteen or fourteen shafts, 9 to 14 feet deep. A layer of blue, gravel composed mainly of schist that is below barren sand and reddish gravel produced gold values of 2-3 cents per pan (with gold at $\$ 20.67$ per ounce). Maddren (1913) reported that gold values of 5 to 10 cents per pan also occurred in bench deposits about 2 miles above the mouth of the creek. The gold in the bench deposits also was in a 1- to 3 foot-thick layer of blue, gravel composed mainly of schist.

\section{Alteration:}

Age of mineralization:

Quaternary.

Deposit model:

Placer Au (Cox and Singer, 1986; model 39a)

Deposit model number (After Cox and Singer, 1986 or Bliss, 1992):

$39 \mathrm{a}$

Production Status: None

Site Status: Inactive

Workings/exploration:

The first mile of the creek was prospected by 13 or 14 shafts. Prospecting, two miles above the mouth found some gold in bench gravels but poor water supply hindered development.

Production notes: 


\section{Reserves:}

\section{Additional comments:}

\section{References:}

Maddren, 1913; Reed, 1938; Heiner and Wolff, 1968; Cobb, 1972 (MF-469); Mulligan, 1974; Cobb, 1976 (OF76-340); Cobb, 1977 (OF77-168B); Maas, 1987; Bundtzen and others, 1990; Swainbank and others, 1991; Swainbank and others, 1993.

Primary reference: Maddren, 1913

Reporter(s): J.M. Britton (Anchorage)

Last report date: $8 / 9 / 2002$ 


\section{Site name(s): Hanshaw Bar}

Site type: Mine

ARDF no.: WI155

Latitude: 67.0013

Quadrangle: WI A-1

Longitude: 150.4714

Location description and accuracy:

The location of Hanshaw Bar is described by Reed (1938) as being on the left limit of the South Fork, Koyukuk River about 4.8 miles above Ironside Bench (in the Bettles quadrangle) and about 0.25 mile above Davis Creek (in the Bettles quadrangle). As plotted here, the mine is on a sand bar on the east bank of the South Fork, in the southwest corner of section 8, T. 25 N., R. 13 W. of the Fairbanks Meridian. Location is accurate within one-half mile.

\section{Commodities:}

Main: $\mathrm{Au}$

Other:

Ore minerals: Gold

\section{Gangue minerals:}

\section{Geologic description:}

Gold, as fine, flat flakes, is distributed throughout 2 to 3 feet of medium- to fairly fine-grained gravel and sand on a high-water bar in the channel of the South Fork, Koyukuk River. The paying gravel and sand lies on a false bedrock of clayey sand. Reed (1938) noted that the average value of the ground was $\$ 0.23$ per square foot of bedrock that the gold had a fineness of 907 . Mining in 1937 was by shoveling into sluice boxes and washing with water from the South Fork (Reed, 1938).

\section{Alteration:}

Age of mineralization:

Quaternary.

Deposit model:

Placer Au (Cox and Singer, 1986; model 39a)

Deposit model number (After Cox and Singer, 1986 or Bliss, 1992):

$39 \mathrm{a}$

Production Status: Yes; small

Site Status: Inactive

Workings/exploration:

Mining in 1937 was by shoveling into sluice boxes and washing with water from the South Fork (Reed, 1938).

Production notes:

Probably minor production. 


\section{Reserves:}

Additional comments:

\section{References:}

Reed, 1938; Cobb, 1972 (MF-469); Cobb, 1976 (OF76-340); Bliss and others, 1988.

Primary reference: Reed, 1938

Reporter(s): J.M. Britton (Anchorage)

Last report date: $8 / 9 / 2002$ 


\section{Site name(s): Tramway Bar}

Site type: Mine

ARDF no.: WI156

Latitude: 67.0851

Quadrangle: WI A-1

Longitude: 150.4976

Location description and accuracy:

Tramway Bar is located on the west side of the Middle Fork, Koyukuk River, about 0.4 mile southsouthwest of Chapman Island; Tramway Bar is labeled on the Wiseman A-1 topographic map. The placer deposit is located on a bench about 80 to 100 feet above river level. The location is accurate.

\section{Commodities:}

Main: $\mathrm{Au}$

Other:

Ore minerals: Gold

\section{Gangue minerals:}

\section{Geologic description:}

The Tramway Bar mine is one of the first placer gold occurrences known in the area; it was discovered as early as 1885 . The gravel that contains the gold is presumed to have been deposited by streams flowing in the Middle Fork Koyukuk River valley prior to downcutting of the Middle Fork canyon. The deposit at Tramway Bar consists of about 4-7 feet of coarse, waterworn, bouldery gravel. It lays on a bench cut in conglomerate and sandstone, along the west side of the Middle Fork canyon wall about 50 - 100 feet above the modern river channel. These gravels were mined across a 50 foot width for about a mile. One mining operation, active in 1937 described by Reed (1938), recovered both coarse, worn, and rounded gold, and very fine, flaky gold. The coarse gold occurs throughout a 3-5 foot section of coarse gravel, but mostly in the lower part. The fine gold occurs mostly in a layer on top of decomposed conglomerate bedrock. No large nuggets accompanied the coarse gold. The early miners were said to have recovered only the coarse gold. Maddren (1913) suggested that the gold at Tramway Bar was derived from the outwash of Chapman Creek. Reed (1938) thought that the coarse gold might have been reconcentrated from outwash material in the Middle Fork valley, and that the fine gold was derived from erosion of the conglomerate bedrock.

Maddren reported production of about \$8,000 in gold (approximately 400 ounces) between 1900 and 1909. Gold values in 1937 were said to be about $\$ 0.31$ per square foot of bedrock (Reed, 1938). Mining continued sporadically at least until 1965 (Cobb, 1973).

\section{Alteration:}

Age of mineralization:

Quaternary.

Deposit model:

Placer Au (Cox and Singer, 1986; model 39a)

Deposit model number (After Cox and Singer, 1986 or Bliss, 1992):

$39 \mathrm{a}$

Production Status: Yes 
Site Status: Inactive

Workings/exploration:

The placer was mined by hand methods such as rocking and shoveling into sluice boxes.

Production notes:

Maddren reported production of about $\$ 8,000$ (approximately 425 oz.) between 1900 and 1909. Gold values in 1937 were said to be about $\$ 0.31$ per square foot of bedrock (Reed, 1938). Mining continued sporadically at least until 1965 (Cobb, 1973).

\section{Reserves:}

\section{Additional comments:}

\section{References:}

Schrader, 1900; Schrader, 1904; Maddren, 1910; Brooks, 1913; Maddren, 1913; Wimmler, 1925; Reed, 1938; Smith, 1941; Smith, 1942; Brosge and Reiser, 1960; Heiner and Wolff, 1968; Brosge and Reiser, 1972; Cobb, 1972 (MF-469); Cobb, 1973 (B1374); Mulligan, 1974; Cobb, 1976 (OF76-340); Bundtzen and others, 1982; Bundtzen and others, 1982; Maas, 1987; Bliss and others, 1988.

Primary reference: Reed, 1938

Reporter(s): J.M. Britton (Anchorage)

Last report date: $8 / 9 / 2002$ 


\section{Site name(s): Mailbox Creek}

Site type: Mine

ARDF no.: WI157

Latitude: 67.1042

Quadrangle: WI A-1

Longitude: 150.4818

Location description and accuracy:

Mailbox Creek is a south-flowing tributary to the Middle Fork, Koyukuk River; its mouth is about 1 mile upstream from Tramway Bar and 4 miles south-southwest of Twelvemile Mountain. Placer mining has been reported 2000 feet upstream from the mouth of Mailbox Creek; the coordinates approximate that location. The location is accurate.

\section{Commodities:}

Main: $\mathrm{Au}$

Other:

Ore minerals: Gold

\section{Gangue minerals:}

\section{Geologic description:}

Placer workings about a half mile upstream from the mouth of Mailbox Creek have recovered gold from fairly fine gravel that contains numerous erratic boulders. The fine gravel is derived mainly from conglomerate bedrock in the area. Fine, flaky gold occurs throughout the gravel; coarser gold is in a layer of reddish gravel near the bedrock surface. The value of the ground being worked in the mid-1930's was reported to be about $\$ 0.75$ per square foot of bedrock. The fineness of the gold is 898 . The State of Alaska reported that a Mining License had been issued for an operation on Mailbox Creek in 1999 (Swainbank and others, 2000). Its issuance, however, does not mean that any mining took place.

\section{Alteration:}

Age of mineralization:

Quaternary.

Deposit model:

Placer Au (Cox and Singer, 1986; model 39a)

Deposit model number (After Cox and Singer, 1986 or Bliss, 1992):

$39 a$

Production Status: Yes

Site Status: Inactive

Workings/exploration:

The placer was mined in the 1930's by ground sluicing and shoveling in from an open cut.

Production notes:

Mining occurred from at least 1934 to 1937. 


\section{Reserves:}

Additional comments:

References:

Smith and Mertie, 1930; Smith, 1937; Reed, 1938; Heiner and Wolff, 1968; Cobb, 1972 (MF-469); Mulligan, 1974; Cobb, 1976 (OF76-340); Cobb, 1981 (OF81-732); Maas, 1987; Bliss and others, 1988; Swainbank and others, 2000.

Primary reference: Reed, 1938

Reporter(s): J.M. Britton (Anchorage)

Last report date: $8 / 9 / 2002$ 


\section{Site name(s): Frisbe Creek}

Site type: Mine

ARDF no.: WI158

Latitude: 67.0140

Quadrangle: WI A-1

Longitude: 150.4163

Location description and accuracy:

Frisbe Creek was described by Reed (1938) as a right-limit tributary to the South Fork, Koyukuk River; it is about 2.5 miles upstream from Davis Creek and just upstream of Grubstake Bar (WI153). Based on Reed's description, Frisbe Creek is inferred to be the south-flowing tributary to the South Fork whose mouth is approximately 0.3 mile upstream from the mouth of Bear Creek. The location of placer activity along the creek is unknown; its location is arbitrarily placed near the mouth of the creek. The location is accurate within one mile.

\section{Commodities:}

Main: $\mathrm{Au}$

Other:

Ore minerals: Gold

Gangue minerals:

Geologic description:

Reed (1938) did not visit Frisbe Creek. He reported that the Frisbe brothers had mined and prospected the creek in the early 1900's, and that no one had mined it since that time. Reed did not know the extent of the mining.

\section{Alteration:}

Age of mineralization:

Quaternary.

Deposit model:

Placer Au (Cox and Singer, 1986; model 39a)

Deposit model number (After Cox and Singer, 1986 or Bliss, 1992):

$39 a$

Production Status: Undetermined.

Site Status: Inactive

Workings/exploration:

Production notes:

Reserves:

Additional comments: 


\section{References:}

Reed, 1938; Cobb, 1977 (OF77-168B).

Primary reference: Reed, 1938

Reporter(s): J.M. Britton (Anchorage)

Last report date: $8 / 9 / 2002$ 


\section{Site name(s): Fryingpan Bar}

Site type: Prospect

ARDF no.: WI159

Latitude: 67.0980

Quadrangle: WI A-1

Longitude: 150.4856

Location description and accuracy:

Fryingpan Bar is on the east side of the Middle Fork, Koyukuk River opposite the mouth of Mailbox Creek (WI157); it is about 1 mile north-northeast of Tramway Bar. The location is accurate within one-half mile.

\section{Commodities:}

Main: $\mathrm{Au}$

Other:

Ore minerals: Gold

Gangue minerals:

Geologic description:

According to Reed (1938), the gold in Fryingpan Bar is derived from the erosion of the high channel of the Middle Fork of the Koyukuk. This channel is on the south side of the river on top of the wall of the Middle Fork Canyon; the channel was forced southward by the action of Mailbox Creek. The placer was mined in 1908 but the results of the mining are unknown.

\section{Alteration:}

Age of mineralization:

Quaternary.

Deposit model:

Placer Au (Cox and Singer, 1986; model 39a)

Deposit model number (After Cox and Singer, 1986 or Bliss, 1992):

$39 \mathrm{a}$

Production Status: Undetermined.

Site Status: Inactive

Workings/exploration:

Mining in 1908 used water pumped from the Middle Fork by steam boiler powered by local coal.

Production notes:

Probably some minor production.

Reserves:

Additional comments: 


\section{References:}

Reed, 1938; Cobb, 1976 (OF76-340); Cobb, 1977 (OF77-168B).

Primary reference: Reed, 1938

Reporter(s): J.M. Britton (Anchorage)

Last report date: $8 / 9 / 2002$ 


\section{Site name(s): Wilson Creek}

Site type: Occurrence

ARDF no.: WI160

Latitude: 67.0663

Quadrangle: WI A-1

Longitude: 150.1766

Location description and accuracy:

Wilson Creek is a south-flowing tributary to South Fork, Koyukuk River. The mouth of Wilson Creek is about 3 or 4 miles west-northwest of Eagle Cliff and 6 miles south of Rosie Creek Pass. The location of placer prospects on the creek are unknown; the coordinates are for a location that is arbitrarily placed near the mouth of Wilson Creek. The location is accurate within one mile.

\section{Commodities:}

Main: $\mathrm{Au}$

Other:

Ore minerals: Gold

\section{Gangue minerals:}

Geologic description:

Maddren (1913) reported that gold is can be found in Wilson Creek but not in paying quantities. Reed (1938) did not visit the creek. He repeated Maddren's (1913) information and indicated that no one was working on the creek in 1937. No other information is available.

\section{Alteration:}

Age of mineralization:

Quaternary.

Deposit model:

Placer Au (Cox and Singer, 1986; model 39a)

Deposit model number (After Cox and Singer, 1986 or Bliss, 1992):

$39 a$

Production Status: None

Site Status: Inactive

Workings/exploration:

Surface prospecting.

Production notes:

Reserves:

Additional comments: 


\section{References:}

Maddren, 1913; Reed, 1938; Heiner and Wolff, 1968; Cobb, 1976 (OF76-340); Cobb, 1981 (OF81-732); Maas, 1987.

Primary reference: Maddren, 1913

Reporter(s): J.M. Britton (Anchorage)

Last report date: $8 / 9 / 2002$ 


\section{References}

Arctic Environmental Information and Data Center, 1982, Mineral terranes of Alaska: University of Alaska, Fairbanks, 7 sheets, scale 1:1,000,000.

Armstrong, E., 1985, The placer geology of the Wiseman area, in Walsh, D.E.and Wray, M.S.(editors), 1985, Sixth Annual Conference on Alaskan Placer Mining: March 28-29, 1984, Fairbanks, Alaska: Mineral Industry Research Laboratory report no.69, 77 p

Berg, H.C., and Cobb, E.H., 1967, Metalliferous lode deposits of Alaska: U.S. Geological Survey Bulletin 1246, $254 \mathrm{p}$.

Bliss, J.D., ed., 1992, Developments in mineral deposit modeling: U.S. Geological Survey Bulletin 2004,168 p.

Bliss, J.D., Brosgé, W.P., Dillon, J.T., Cathrall, J.B., and Dutro, J.T.Jr., 1988, Maps and descriptions of lode deposits, prospects, and occurrences in the Wiseman 1o by 3o Quadrangle, Alaska: U.S. Geological Survey Open-File Report 88-293, 52 p.plus 2 plates.

Britton, J.M., 2000, Alaska resource data file: Chandalar quadrangle, Alaska: U.S. Geological Survey Open-File Report 00-357, 248 p.

Brooks, A.H., 1904, Placer mining in Alaska in 1903: U.S. Geological Survey Bulletin 225, p.43-59.

Brooks, A.H., 1905, Placer mining in Alaska in 1904: U.S. Geological Survey Bulletin 259, p.18-31.

Brooks, A.H., 1908, The mining industry in 1907: U.S. Geological Survey Bulletin 345, p.30-53.

Brooks, A.H., 1909, The mining industry in 1908: U.S. Geological Survey Bulletin 379, p.21-62.

Brooks, A.H., 1911, The mining industry in 1910: U.S. Geological Survey Bulletin 480, p.21-42.

Brooks, A.H., 1912, The mining industry in 1911: U.S. Geological Survey Bulletin 520, p.17-44.

Brooks, A.H., 1913, The mining industry in 1912: U.S. Geological Survey Bulletin 542, p.18-51.

Brooks, A.H., 1914, The Alaskan mining industry in 1913: U.S. Geological Survey Bulletin 592, p.45-74.

Brooks, A.H., 1915, The Alaskan mining industry in 1914: U.S. Geological Survey Bulletin 622, p.15-68.

Brooks, A.H., 1916, The Alaskan mining industry in 1915: U.S. Geological Survey Bulletin 642, p.16-71.

Brooks, A.H., 1918, The Alaskan mining industry in 1916: U.S. Geological Survey Bulletin 662, p.11-62.

Brooks, A.H., 1922, The Alaskan mining industry in 1920: U.S. Geological Survey Bulletin 722, p.7-67.

Brooks, A.H., 1923, The Alaska mining industry in 1921: U.S. Geological Survey Bulletin 739, p.1-44.

Brooks, A.H., and Capps, S.R., 1924, The Alaska mining industry in 1922: U.S. Geological Survey Bulletin 755, p.3-49.

Brooks, A.H., and Martin, G.C., 1921, The Alaskan mining industry in 1919: U.S. Geological Survey Bulletin 714, p.59-95.

Brosgé, W.P., and Reiser, H.N., 1960, Progress map of the geology of the Wiseman quadrangle, Alaska: U.S. Geological Survey Open-File Report 60-19, 2 sheets, scale 1:250,000. 
Brosgé, W.P., and Reiser, H.N., 1970, Chemical analysis of rock and soil samples from the Chandalar and eastern Wiseman quadrangles, Alaska: U.S. Geological Survey Open-File Report 70-39, $8 \mathrm{p}$.

Brosgé, W.P., and Reiser, H.N., 1971, Preliminary bedrock geologic map, Wiseman and eastern Survey Pass quadrangles, Alaska: U.S. Geological Survey Open-File Report 71-0056, 2 sheets, scale 1:250,000.

Brosgé, W.P., and Reiser, H.N., 1972, Geochemical reconnaissance in the Wiseman and Chandalar districts and adjacent region, southern Brooks Range, Alaska: U.S. Geological Survey Professional Paper 709, 21 p.

Bundtzen, T.K., Eakins, G.R., Clough, J.G., Lueck, L.L., Green, C.B., Robinson, M.S., and Coleman, D.A., 1984, Alaska's mineral industry 1983: Alaska Division of Geological and Geophysical Surveys Special Report 33, 56 p.

Bundtzen, T.K., Eakins, G.R., and Conwell, C.N., 1982, Alaska mineral resources 1981-82: Alaska Division of Geological and Geophysical Surveys Annual Report 1981-82, 153 p., 4 sheets, scale 1:2,500,000.

Bundtzen, T.K., Eakins, G R., Green, C.B., and Lueck, L.L., 1986, Alaska's mineral industry 1985: Alaska Division of Geological and Geophysical Surveys Special Report 39, 68 p.

Bundtzen, T.K., Green, C.B., Deagen, J.R., and Daniels, C.L., 1987, Alaska's mineral industry 1986: Alaska Division of Geological and Geophysical Surveys Special Report 40, 68 p.

Bundtzen, T.K., Green, C.B., Peterson, R.J., and Seward, A.F., 1988, Alaska's mineral industry 1987: Alaska Division of Geological and Geophysical Surveys Special Report 41, 69 p.

Bundtzen, T.K., Swainbank, R.C., Clough, A.H., Henning, M.W., and Charlie, K.M., 1996, Alaska's mineral industry 1995: Alaska Division of Geological and Geophysical Surveys Special Report 50, 72 p.

Bundtzen, T.K., Swainbank, R.C., Clough, A.H., Henning, M.W., and Hansen, E.W., 1994, Alaska's Mineral Industry 1993: Alaska Division of Geological and Geophysical Surveys Special Report 48, 84 p.

Bundtzen, T.K., Swainbank, R.C., Deagen, J.R., and Moore, J.L., 1990, Alaska's mineral industry 1989: Alaska Division of Geological and Geophysical Surveys Special Report 44, 100 p.

Bundtzen, T.K., Swainbank, R.C., Wood, J.E., and Clough, A.H., 1992, Alaska's mineral industry 1991: Alaska Division of Geological and Geophysical Surveys Special Report 46, 89 p.

Carnes, D.R., 1976, Active Alaskan placer operations, 1975: U.S.Bureau of Mines Open-File Report 98-76, 90 p., 40 maps

Chipp, E.R., 1972, Analyses of rock and stream sediment samples, Wild Lake area, Wiseman quadrangle, Arctic Alaska: Alaska Division Geological Survey Geochemical Report 25, 2 sheets.

Cobb, E.H., 1972, Metallic mineral resources map of the Wiseman quadrangle, Alaska: U.S. Geological Survey Miscellaneous Field Studies Map MF-469, 1 sheet, scale 1:250,000

Cobb, E.H., 1973, Placer deposits of Alaska: U.S. Geological Survey Bulletin 1374, 213 p.

Cobb, E.H., 1975, Tungsten occurrences in Alaska: U.S. Geological Survey Mineral Investigation Resource Map MR-66, scale 1:2,500,000.

Cobb, E.H, 1976, Summary of references to mineral occurrences (other than mineral fuels and construction materials) in the Chandalar and Wiseman quadrangles, Alaska: U.S. Geological Survey Open-File Report 76340,205 p. 
Cobb, E.H, 1977, Placer deposits map of central Alaska, U.S. Geological Survey Open-File Report 77-168-B, 65 p., 1 sheet, scale 1:2,500,000

Cobb, E.H, 1981, Summary of data on and list of references to metallic mineral occurrences in the Wiseman quadrangle, Alaska; supplement to Open-File Report 76-340: Part A-summary of data to January 1, 1981: U.S. Geological Survey Open-File Report 81-732-A, 20 p.

Cox, D.P., and Singer, D.A., eds., 1986, Mineral deposit models: U.S. Geological Survey Bulletin 1693,379 p.

Degenhart, C.E., Griffis, R.J., McQuat, J.F., and Bigelow, C.G., 1978, Mineral studies of the western Brooks Range performed under contract to the U.S.Bureau of Mines, Contract \#JO155089: U.S.Bureau of Mines Open-File Report 103-78, 529 p., 11 sheets.

Dillon, J.T., 1982, Source of lode and placer gold deposits of the Chandalar and upper Koyukuk Districts: Alaska Division of Geological and Geophysical Surveys Open-File Report 158, 25 p., 1 sheet, scale 1:250,000.

Dillon, J.T., 1987, Upper Koyukuk District land and mining claim status current to 1985: Alaska Division of Geological and Geophysical Surveys Public-Data File 87-11, 1 sheet, scale 1:125,000.

Dillon, J.T., Brosgé, W.P., and Dutro, J.T., Jr., 1986, Generalized geologic map of the Wiseman quadrangle, Alaska: U.S. Geological Survey Open-File Report 86-219, 1 sheet, scale 1:250,000.

Dillon, J.T., Cathrall, J.B., and Moorman, M.A., 1981, Geochemical reconnaissance of the southwest Wiseman quadrangle-summary of data on pan-concentrate and stream-sediment samples: Alaska Division of Geological and Geophysical Surveys Open-File Report 133A, 164 p.

Dillon, J.T., Cathrall, J.B., and Moorman, M.A., 1981, Geochemical reconnaissance of the southwest Wiseman quadrangle-summary of data on rock samples: Alaska Division of Geological and Geophysical Surveys Open-File Report 133B, 164 p.

Dillon, J.T., and Reifenstuhl, R.R., 1990, Geologic map of the Wiseman B-1 Quadrangle, southcentral Brooks Range, Alaska: Alaska Division of Geological \& Geophysical Surveys, Professional Report 101, 1 sheet, scale $1: 63,360$.

Eakins, G.R., Bundtzen, T.K., Lueck, L.L., Green, C.B., Gallagher, J.L., and Robinson, M.S., 1985, Alaska's mineral industry 1984: Alaska Division of Geological and Geophysical Surveys Special Report 38, 57 p.

Eakins, G.R., Bundtzen, T.K., Robinson, M.S., Clough, J.G., Green, C.B., Clautice, K.H., and Albanese, M.A., 1983, Alaska's mineral industry 1982: Alaska Division of Geological and Geophysical Surveys Special Report 31, 68 p.

Ebbley, Norman, Jr., and Wright, W.S., 1948, Antimony deposits in Alaska: U.S.Bureau of Mines Report of Investigation $4173,41 \mathrm{p}$.

Eden, K., 2000, Geology and gold mineralization of the Nolan area in the Brooks Range, Alaska: U.S.Bureau of Land Management Open-File Report 78, 87 p.

Green, C.B., Bundtzen, T.K., Peterson, R.J., Seward, A.F., Deagen, J.R., and Burton, J.E., 1989, Alaska's mineral industry 1988: Alaska Division of Geological and Geophysical Surveys Special Report 43, 79 p.

Grybeck, Donald, 1977, Known mineral deposits of the Brooks Range, Alaska: U.S. Geological Survey OpenFile Report 77-166C, 45 p., 1 map, scale 1:1,000,000.

Heiner, L.E.and Wolff, E.N. (editors), 1968, Mineral resources of northern Alaska: Final report, submitted to the NORTH Commission, M.I.R.L.report no.16, 306 p. 
Holdsworth, P.R., 1952, Report of the commissioner of mines for the biennium ended December 31, 1952: Alaska Territorial Department of Mines Annual Report 1952, 66 p.

Holdsworth, P.R., 1957, Report of the commissioner of mines for the biennium ended December 31, 1956: Alaska Territorial Department of Mines Annual Report 1956, 103 p.

Joesting, H.R., 1942, Strategic mineral occurrences in interior Alaska: Alaska Territorial Department of Mines Pamphlet 1, $46 \mathrm{p}$.

Joesting, H.R., 1943, Supplement to Pamphlet No.1--Strategic mineral occurrences in interior Alaska: Alaska Territorial Department of Mines Pamphlet 2, $28 \mathrm{p}$.

Klieforth, R.F., Kurtak, J.M., Clark, J.M., and Maclean, E.A., 2001, Analytical results from mineral investigations in the Koyukuk Mining district, Northern Alaska: U.S.Bureau of Land Management Open-File Report $84,38 \mathrm{p}$.

Kurtak, J.M., Klieforth, R.F., Clark, J.M., and Williams, E.M., 1999, Mineral investigations in the Koyukuk mining district, northern Alaska: Progress Report, U.S.Bureau of Land Management Open-File Report 74, $158 \mathrm{p}$.

Kurtak, J.M., Klieforth, R.F., Clark, J.M., and Maclean, E.A., 2002, Mineral investigations in the Koyukuk mining district, northern Alaska: Final Report, U.S.Bureau of Land Management Technical Report 50, v.1 and $2,845 \mathrm{p}$.

Maas, K.M., 1987, Maps summarizing land availability for mineral exploration and development in northern Alaska, 1986: U.S.Bureau of Mines Open-File Report 10-87, 33 sheets.

Maddren, A.G., 1910, The Koyukuk-Chandalar gold region: U.S. Geological Survey Bulletin 442, p.284-315.

Maddren, A.G., 1913, The Koyukuk-Chandalar region, Alaska: U.S. Geological Survey Bulletin 532, 119 p.

Moffit, F.H., 1927, Mineral industry of Alaska in 1925: U.S. Geological Survey Bulletin 792, p.1-39

Mosier, E.L., and Lewis, J.S., 1986, Analytical results, geochemical signatures, and sample locality map of lode gold, placer gold, and heavy-mineral concentrates from the Koyukuk-Chandalar mining district, Alaska: U.S. Geological Survey Open-File Report 86-345, 172 p.

Mulligan, J.J., 1974, Mineral resources of the Trans-Alaska Pipeline Corridor: U.S.Bureau of Mines Information Circular 8626, 24 p.

Nokleberg, W.J., Bundtzen, T.K., Berg, H.C., Brew, D.A., Grybeck, D., Robinson, M.S., Smith, T.E., and Yeend, W., 1987, Significant metalliferous lode deposits and placer districts of Alaska, U.S. Geological Survey Bulletin 1786, $104 \mathrm{p}$.

Nokleberg, W.J., Bundtzen, T.K., Dawson, K.M., Eremin, R.A., Goryachev, N.A., Koch, R.D., Ratkin, V.V., Rozenblum, I.S., Shpikerman, V.I., Frolov, Y.F., Gorodinsky, M.E., Melnikov, V.D., Diggles, M.F., Ognyanov, N.V., Petrachenko, E.D., Petrachenko, R.I., Pozdeev, A.I., Ross, K.V., Wood, D.H., Grybeck, D., Khanchuck, A.I., Kovbas, L.I., Nekrasov, I.Y., and Sidorov, A.A., 1996, Significant metalliferous lode deposits and placer districts for the Russian Far East, Alaska, and the Canadian Cordillera: U.S. Geological Survey Open-File Report 96-513-A (paper format), 385 p.; U.S. Geological Survey Open-File Report 96-513-B (CD-ROM format).

Orris, G.J., and Bliss, J.D., 1985, Geologic and grade-volume data on 330 Au placer deposits: U.S. Geological Survey Open-File Report 85-213, 172 p. 
Overstreet, W.C., 1967, The geologic occurrence of monazite: U.S. Geological Survey Professional Paper 530, 327 p.

Reed, I.M., 1938, Upper Koyukuk region, Alaska (Wiseman, Chandalar, and Bettles): Alaska Territorial Department of Mines Miscellaneous Report 194-7, 201 p.

Roehm, J.C., 1949, Report of investigations and itinerary of J.C.Roehm, Associate Mining Engineer, Territorial Department of Mines, in the Koyukuk precinct, Alaska Precinct, Alaska: Alaska Division of Geological and Geophysical Surveys Itinerary Report IR031-1, 9 p.

Saarela, L.H., 1949, Report of the commissioner of mines for the biennium ended December 31, 1948: Alaska Territorial Department of Mines Annual Report 1948, 50 p.

Saunders, R.H., 1954, Koyukuk District Operations (Wiseman, Chandalar): Alaska Territorial Department of Mines Miscellaneous Report MR-194-16, 8 p.

Schrader, F.C., 1900, Preliminary report on a reconnaissance along the Chandalar and Koyukuk Rivers, Alaska, in 1899: U.S. Geological Survey 21st Annual Report, pt.2, p.441-486

Schrader, F.C., 1904, A reconnaissance in northern Alaska across the Rocky Mountains, along Koyukuk, John, Anaktuvuk, and Colville rivers and the Arctic coast to Cape Lisburne, in 1901, with notes by W.J.Peters: U.S. Geological Survey Professional Paper 20, 139 p.

Smith, P.S., 1912, The Alatna-Noatak region: U.S. Geological Survey Bulletin 520, p.315-338.

Smith, P.S., 1913, The Noatak-Kobuk region: U.S. Geological Survey Bulletin 536, 160 p.

Smith, P.S., 1929, Mineral industry of Alaska in 1926: U.S. Geological Survey Bulletin 797, p.1-50.

Smith, P.S., 1930, Mineral industry of Alaska in 1927: U.S. Geological Survey Bulletin 810, p.1-64.

Smith, P.S., 1930, Mineral industry of Alaska in 1928: U.S. Geological Survey Bulletin 813, p.1-72.

Smith, P.S., 1932, Mineral industry of Alaska in 1929: U.S. Geological Survey Bulletin 824, p.1-81.

Smith, P.S., 1933, Mineral industry of Alaska in 1930: U.S. Geological Survey Bulletin 836, p.1-83.

Smith, P.S., 1933, Mineral industry of Alaska in 1931: U.S. Geological Survey Bulletin 844-A, p.1-82.

Smith, P.S., 1934, Mineral industry of Alaska in 1932: U.S. Geological Survey Bulletin 857-A, p.1-91.

Smith, P.S., 1934, Mineral industry of Alaska in 1933: U.S. Geological Survey Bulletin 864-A, p.1-94.

Smith, P.S., 1936, Mineral industry of Alaska in 1934: U.S. Geological Survey Bulletin 868-A, p.1-91.

Smith, P.S., 1937, Mineral industry of Alaska in 1935: U.S. Geological Survey Bulletin 880-A, p.1-95.

Smith, P.S., 1938, Mineral industry of Alaska in 1936: U.S. Geological Survey Bulletin 897-A, p.1-107.

Smith, P.S., 1939, Mineral industry of Alaska in 1937: U.S. Geological Survey Bulletin 910-A, p.1-113.

Smith, P.S., 1939, Mineral industry of Alaska in 1938: U.S. Geological Survey Bulletin 917-A, p.1-113.

Smith, P.S., 1941, Mineral industry of Alaska in 1939: U.S. Geological Survey Bulletin 926-A, p.1-106. 
Smith, P.S., 1942, Mineral industry of Alaska in 1940: U.S. Geological Survey Bulletin 933-

A, p.1-102.

Smith, P.S., and Mertie, J.B., Jr., 1930, Geology and mineral resources of northwestern Alaska: U.S. Geological Survey Bulletin 815, $351 \mathrm{p}$

Smith, S.S., 1917, The mining industry in the Territory of Alaska during the calendar year 1915: U.S.Bureau of Mines Bulletin 142, $66 \mathrm{p}$.

Smith, S.S., 1917, The mining industry in the Territory of Alaska during the calendar year 1916: U.S.Bureau of Mines Bulletin 153, 89 p.

Stewart, B.D., 1949, Report of the commissioner of mines for the biennium ended December 31, 1948: Alaska Territorial Annual Report 1948, 50 p.

Swainbank, R.C., Bundtzen, T.K., Clough, A.H., Hansen, E.W., and Nelson, M.G., 1993, Alaska's mineral industry 1992: Alaska Division of Geological and Geophysical Surveys Special Report 47, 80 p.

Swainbank, R.C., Bundtzen, T.K., Clough, A.H., and Henning, M.W., 1997, Alaska's mineral industry 1996: Alaska Division of Geological and Geophysical Surveys Special Report 51, 68 p.

Swainbank, R.C., Bundtzen, T.K., Clough, A.H., Henning, M.W., and Hansen, E.W., 1995, Alaska's mineral industry 1994: Alaska Division of Geological and Geophysical Surveys Special Report 49, 77 p.

Swainbank, R.C., Bundtzen, T.K., and Wood, J.M., 1991, Alaska's mineral industry 1990: Alaska Division of Geological and Geophysical Surveys Special Report 45, 78 p.

Swainbank, R.C., Clautice, K.H., and Nauman, J.L., 1998, Alaska's mineral industry 1997: Alaska Division of Geological and Geophysical Surveys Special Report 52, 65 p.

Swainbank, R.C., Szumigala, D.J., Henning, M.W., and Pillifant, F.M., 2000, Alaska's mineral industry 1999: Alaska Division of Geological and Geophysical Surveys Special Report 54, 73 p.

Szumigala, D.J., and Swainbank, R.C., 1999, Alaska's mineral industry 1998: Alaska Division of Geological and Geophysical Surveys Special Report 53, 71 p.

Szumigala, D.J., Swainbank, R.C., Henning, M.W., and Pillifant, F.M., 2001, Alaska's mineral industry 2000: Alaska Division of Geological and Geophysical Surveys Special Report 55, 66 p.

Thorne, R.L., Muir, N.M., Erickson, A.W., Thomas, B.I., Heide, H.E., and Wright, W.S., 1948, Tungsten deposits in Alaska: U.S.Bureau of Mines Report of Investigation 4174, 22 p.

U.S. Bureau of Mines, 1973, Alaska 1:250,000-scale quadrangle map overlays showing mineral deposit locations, principal minerals, and number and type of claims: U.S.Bureau of Mines Open-File Report 20-73, 95 overlays (updated in 1986, 1987).

U.S. Bureau of Mines, 1978, Mineral appraisal of the proposed Gates of the Arctic Wilderness National Park, Alaska: A Preliminary Comment: U.S.Bureau of Mines Open-File Report 109-78, 29 p., 4 sheets.

U.S. Bureau of Mines, 1979, A mineral appraisal of the areas traversed by the Kobuk, Killik, Alatna, and John Rivers and the North Fork of the Koyukuk River, Alaska: A Summary Report: U.S.Bureau of Mines Open-File Report 36-79, 23 p., 1 sheet.

U.S. Bureau of Mines, 2000, U.S.Bureau of Mines Alaska Mineral Locations Database (MAS/MILS), Wiseman quadrangle: Worldwide Web URL http://imcg.wr.usgS. Gov/dem.html 
Wedow, Helmuth, Jr., White, M.G., and Moxham, R.M., 1953, Interim report on an appraisal of the uranium possibilities of Alaska: U.S. Geological Survey Open-File Report 51, 123 p.

White, M.G., 1952, Radioactivity of selected rock and placer concentrates from northeastern Alaska: U.S. Geological Survey Circular 195, 12 p.

Williams, J.A., 1950, Mining operations in the Fairbanks district and Innoko and Koyukuk precincts: Alaska Territorial Department of Mines Miscellaneous Report 194-13, 20 p.

Wimmler, N.L., 1922, Placer mining in Alaska in 1922: Alaska Territorial Department of Mines Miscellaneous Report 195-6, 77 p.

Wimmler, N.L., 1925, Placer mining in Alaska in 1925: Alaska Territorial Department of Mines Miscellaneous Report 195-8, 118 p.

Wimmler, N.L., 1929, Placer Mining in Alaska in 1929: Alaska Territorial Department of Mines Miscellaneous Report MR-195-12, p.229. 